\author{
Universidade de São Paulo \\ Instituto de Astronomia, Geofísica e Ciências Atmosféricas \\ Departamento de Astronomia
}

Carolina Silveira Leite

\title{
AS CIÊNCIAS DA TERRA E DO UNIVERSO E SUAS POSSIBILIDADES INTERDISCIPLINARES: \\ UM ESTUDO COM ALUNOS DO 5 ANO DO ENSINO FUNDAMENTAL
}

São Paulo 

Carolina Silveira Leite

\section{AS CIÊNCIAS DA TERRA E DO UNIVERSO E SUAS POSSIBILIDADES INTERDISCIPLINARES: UM ESTUDO COM ALUNOS DO 5 ANO DO ENSINO FUNDAMENTAL}

Dissertação apresentada ao Departamento de Astronomia do Instituto de Astronomia, Geofísica e Ciências Atmosféricas da Universidade de São Paulo como requisito parcial para obtenção do título de Mestre do Programa de Mestrado Profissional em Ensino de Astronomia.

Orientador: Prof. Dr. Eder Cassola Molina

São Paulo 

Dedico à minha mãe Valquíria Clini, minha maior incentivadora $e$ aos meus alunos que sempre se revelaram curiosos e apaixonados pelo aprender. 



\section{AGRADECIMENTOS}

Ao meu orientador Prof. Dr. Eder Cassola Molina, pela confiança, incentivo e paciência;

À EMEF anexa ao Educandário Dom Duarte, representados na figura da diretora Laura Clementino, e suas coordenadoras pedagógicas que sempre apoiaram meu trabalho: Waléria Gomes e Ana Paula Prado.

Aos meus alunos que se engajaram neste trabalho com curiosidade e interesse.

Aos meus colegas professores, em especial a Vanessa Inagaki, Elizabeth Ashida, Conceição Martinelli, Renata Pellaes, Tais Souza, Káthia Kobal, Juliana Fiore por acreditarem que este trabalho poderia se realizar, me incentivando e ajudando sempre.

Aos colegas de MPEA pelas reflexões e debates durante o curso de mestrado: Silvio Fernandez, Andreia Azevedo, Antônio Amaral e Manoel.

Aos professores do Mestrado Profissional do IAG pela oportunidade de aprender: Elysandra Cypriano, José Ademir, Enos Picazzio, Nelson Leister, Jorge Horvath, Amâncio Friaça e Roberto Costa.

Ao companheiro e amigo Antenor Thomé por me ouvir e me apoiar nesse trabalho tão intenso, e sempre fotografar a Lua, meu astro favorito.

À minha mãe Valquíria e ao meu irmão Maurício por me apoiarem e compreenderem nos momentos mais difíceis dessa jornada. 

"Só se vê bem com o coração, o essencial é invisível aos olhos."

Antoine de Saint-Exupéry 



\section{RESUMO}

A Astronomia é uma das mais antigas ciências criadas pela humanidade. Talvez pelo encantamento de observar as estrelas e perguntar-se o que elas faziam ali, é que o ser humano aperfeiçoou instrumentos que permitiram enxergar além de seus próprios olhos. Embora seja uma ciência antiga, mantém-se moderna e está em constante transformação, e suas contribuições são relevantes até os dias atuais.

No contexto escolar, a Astronomia tem o potencial de encantar e fascinar; entretanto, o que vivenciamos é uma desvalorização de sua importância pela abordagem do tema em sala de aula, que algumas vezes é inadequado. Os professores, de modo geral, mostram-se despreparados para a abordagem de um assunto tão complexo, cometendo muitos equívocos, apoiados em livros didáticos.

A proposta deste trabalho foi a elaboração de uma Sequência Didática interdisciplinar para trabalhar assuntos relacionados a conceitos básicos das ciências da Terra e do Universo, focando o Sistema Solar, e comparando as diferenças da Terra com os demais planetas.

A SD foi planejada de acordo com a validação no processo EAR (Elaboração, Aplicação e Reelaboração), para alunos do $5^{\circ}$ ano do Ensino Fundamental. Fruto disso é a organização de um Material de Apoio ao professor, que qualquer profissional da educação pode utilizar e adaptar ao seu contexto.

Deseja-se com esta proposta promover a ampliação dos estudos de Astronomia e das Ciências da Terra nas escolas, de modo a oferecer aos professores das séries iniciais do Ensino Fundamental atividades que proporcionem uma aprendizagem significativa e motivadora, estimulando a aquisição da alfabetização científica, por meio da investigação e pesquisa. Espera-se favorecer com isso a compreensão de que o estudo de Astronomia e do planeta Terra pode contribuir com todas as áreas do conhecimento.

Palavras-chave: Ensino de Astronomia; Sequência Didática; Educação Básica; Material de Apoio; Alfabetização Científica. 



\section{ABSTRACT}

Astronomy is one of the most ancient sciences created by humanity. Perhaps it's because of the fascination of observing the stars and wondering what were they doing there that human beings improved the tools that allow us to see beyond our eyes. Even though it's an ancient science it remains modern and is in constant transformation, and its contributions are revelant up until now.

In an educational context, Astronomy has the potential to fascinate, although what we experience in practice is the devaluation of its importance due the approach of the theme in classrooms, which is at times inadequate. Teachers, in general, present themselves unprepared to explain such complex matters, making several mistakes based on textbooks.

The proposal of this work was the elaboration of an interdisciplinary didactic sequence to work with topics related to basic concepts regarding Earth and Space/Astronomical Sciences, with a focus on the solar system, and the comparison of the differences between Earth and the other planets.

The didactic sequence was planned according to the validation in the EAR (elaboration, application and re-elaboration) for fifth grade students. It's result is the organization of a teacher's guide so that any education professional can use and adapt it to his/her context.

The main point of this proposal is to promote a broadening of Astronomy and Earth Science studies in schools in order to offer primary school teachers activities that provide a meaningful and motivating learning experience, stimulating the acquisition of scientific literacy through investigation and research. With this work we hope to encourage the comprehension that Astromomy and Earth studies can contribute within all the knowledge areas.

Keywords: Astronomy teaching; didactic sequence; basic education; support material; scientific literacy. 



\section{LISTA DE FIGURAS}

Figura 1 - Representação esquemática do Processo EAR................................................29

Figura 2 - Hipóteses levantadas pelos alunos sobre o que é o Universo..................................41

Figura 3 - Estudante procurando no dicionário o significado de Universo...............................42

Figura 4 - Estudantes procurando no dicionário e em enciclopédia o significado de Universo ............................................................................................................

Figura 5 - Conceitos encontrados pelos estudantes....................................................42

Figura 6 - Fotografia para mostrar parte da Via Láctea...................................................4

Figura 7 - Quadro de Jacopo Tintoretto - The Origin of the Milky Way (A origem da Via Láctea)

Figura 8 - Estudantes observando imagens e curtos vídeos do Sol em 3D............................51

Figura 9 - Estudantes jogando o jogo "Uma jornada solar” ..............................................52

Figura 10 - Estudante selecionando informações no texto.................................................54

Figura 11 - Estudantes representando a noite e o dia com o globo terrestre...........................55

Figura 12 - Estudantes representando o movimento de translação........................................55

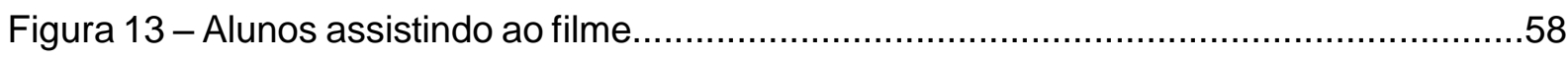

Figura 14 - Perguntas elaboradas pelos estudantes sobre a Lua..........................................59

Figura 15 - Diferenças e semelhanças apontadas pelos alunos acerca dos vídeos

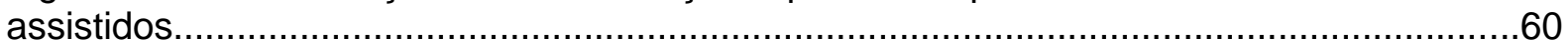

Figura 16 - Professora auxiliando os alunos na leitura do texto..............................................61

Figura 17 - Professora realizando a leitura compartilhada do texto.......................................61

Figura 18 - Aluno grifando informações importantes no texto ...............................................62

Figura 19 - Estudantes observando a simulação das fases da Lua ......................................62

Figura 20 - Alunos desenhando o que observaram no experimento .....................................63

Figura 21 - Algumas imagens da simulação das fases da Lua ..............................................63

Figura 22 - Divisão dos grupos para a pesquisa sobre planetas ...........................................66

Figura 23 - Estudantes confeccionando cartazes sobre os planetas ...................................67

Figura 24 - Estudantes apresentando sua pesquisa …………………….....................67

Figura 25 - Estudantes apresentando sua pesquisa …………………………….......68

Figura 26 - Estudante preenchendo a autoavaliação ....................................................68

Figura 27 - Estudantes confeccionando os planetas com massinha de modelar ....................70

Figura 28 - Estudantes confeccionando planetas com massinha de modelar..........................70

Figura 29 - Atividade sobre o volume dos planetas ......................................................71

Figura 30 - Atividade completa sobre o volume dos planetas ..............................................73

Figura 31 - Alunos comparando a diferença de tamanhos ..................................................73

Figura 32 - Alunos comparando a proporção da Terra com o Sol ........................................74

Figura 33 - Alunos observando as distâncias proporcionais dos planetas em relação ao

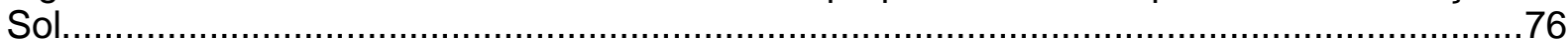


Figura 34 - Alunos reunidos para a realização da atividade sobre a distância proporcional dos

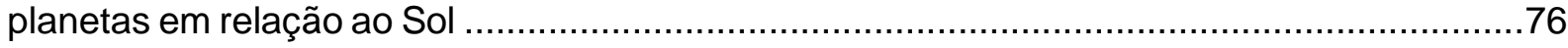

Figura 35 - Estudantes jogando "Uma aventura pelo Sistema Solar" ..................................78

Figura 36 - Estudantes jogando "Uma aventura pelo Sistema Solar" .................................78

Figura 37 - Estudante lendo cartas do jogo ................................................................

Figura 38 - Aluna analisando o desenho feito no início da SD ........................................... 81

Figura 39 - Aluno confeccionando seu novo desenho após a participação na SD ..............81

Figura 40 - Aluna analisando o desenho feito antes de iniciar a SD .....................................81

Figura 41 - Aluna respondendo ao questionário final ...................................................... 82

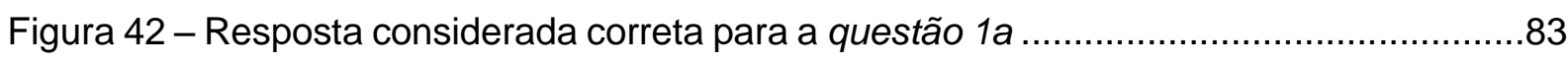

Figura 43 - Resposta considerada correta para a questão 1 a...........................................84

Figura 44 - Resposta considerada parcial para a questão 1a............................................84

Figura 45 - Resposta considerada parcial para a questão 1 a.............................................84

Figura 46 - Resposta considerada incorreta para a questão 1a.........................................84

Figura 47 - Resposta considerada como não respondeu na questão 1 a................................84

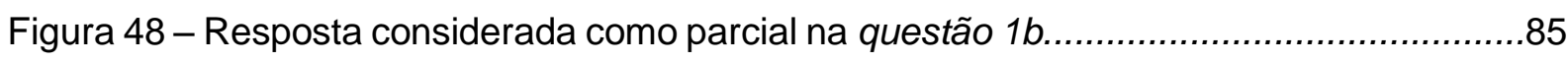

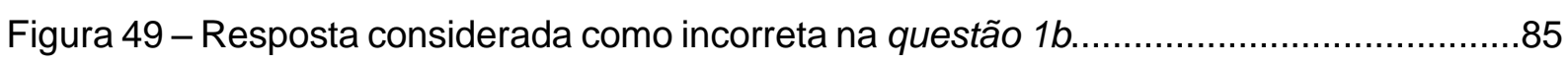

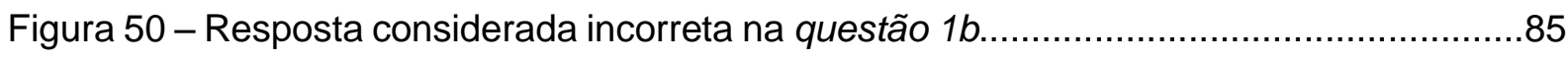

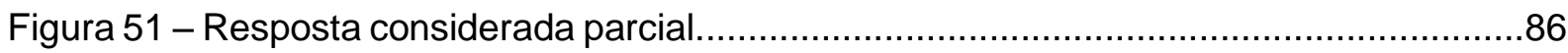

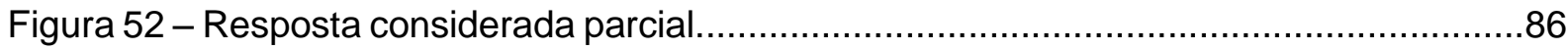

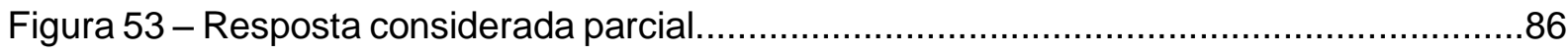

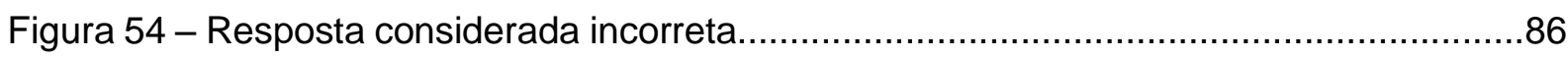

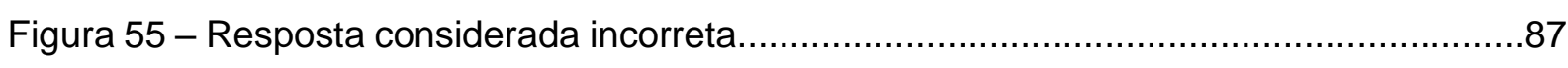

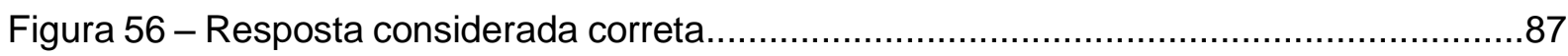

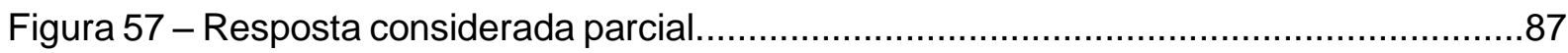

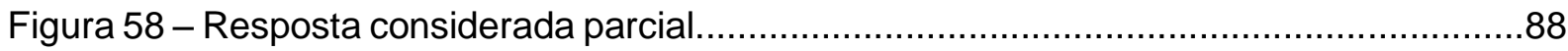

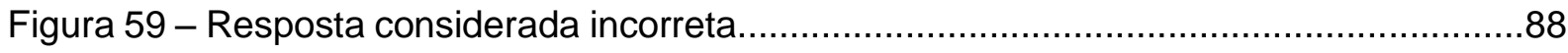

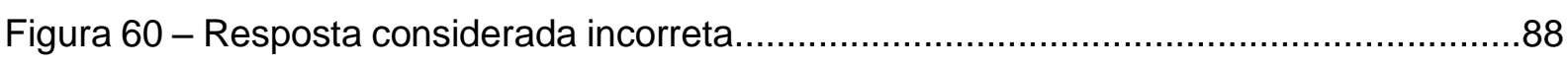

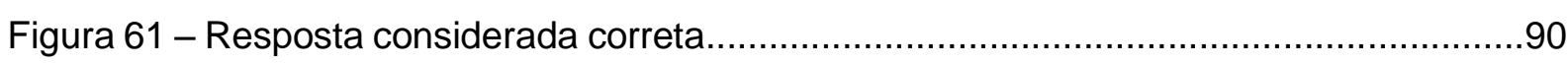

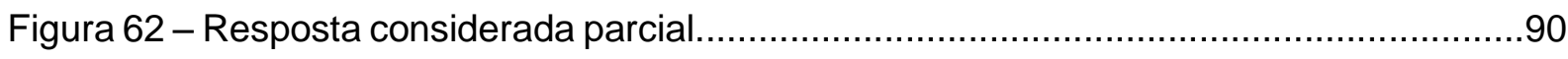

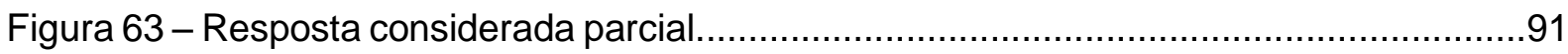

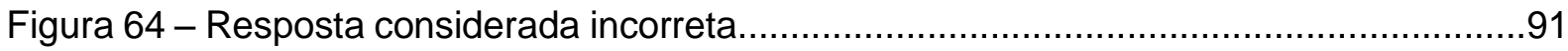

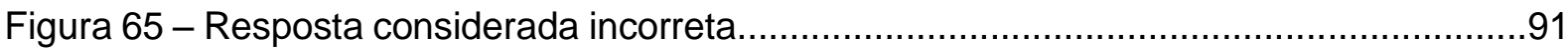

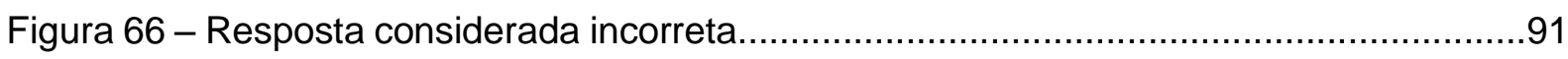

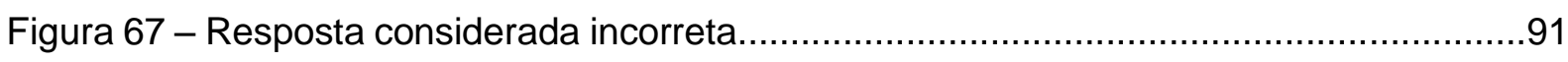

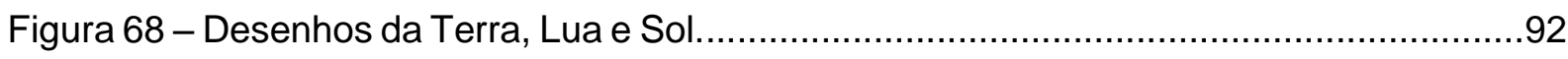

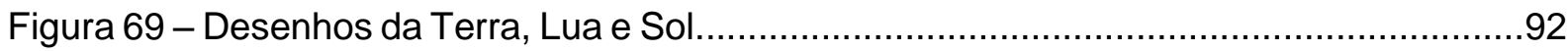




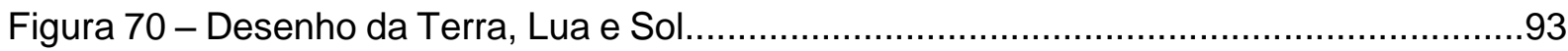

Figura 71 - Desenho de locais onde os alunos "moram" .......................................................

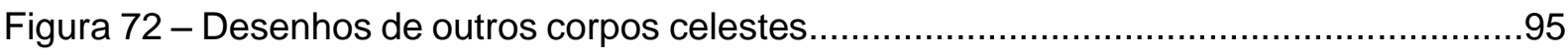

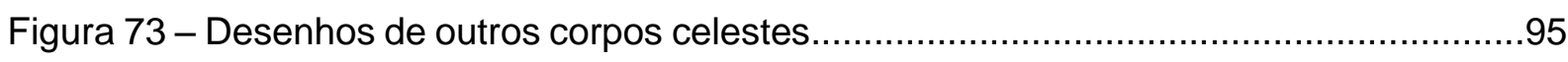

Figura 74 - Desenhos de outros corpos celestes.......................................................95

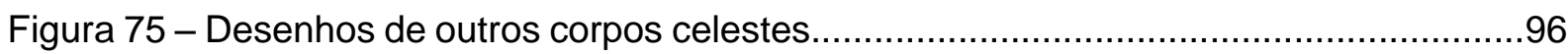

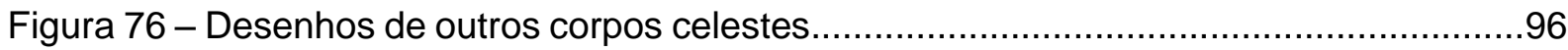

Figura 77 - Pesquisa apresentada sobre lendas para a origem do mundo...........................99

Figura 78 - Pesquisa apresentada sobre lendas para a origem do mundo............................99

Figura 79 - Pesquisa apresentada sobre lendas para a origem do mundo..........................100

Figura 80 - Pesquisa apresentada sobre lendas para a origem do mundo..........................100

Figura 81 - Constelação de Andrômeda..............................................................................101

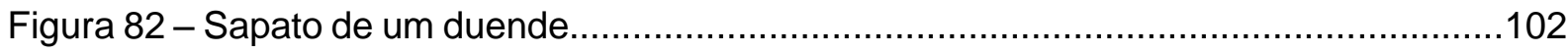

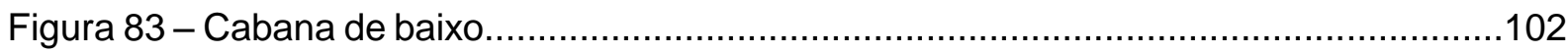

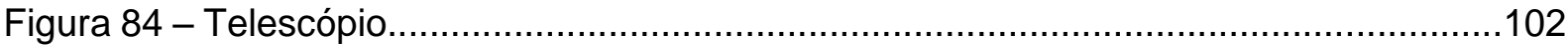

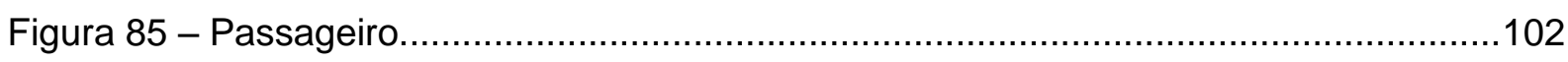

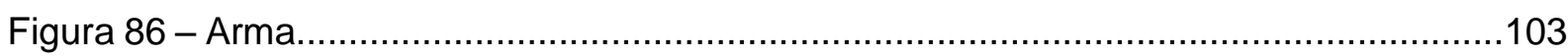

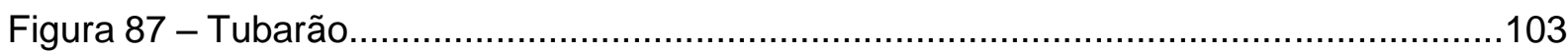

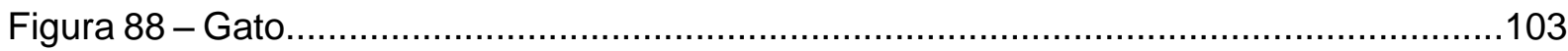

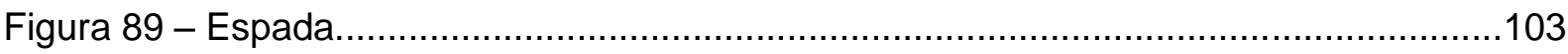

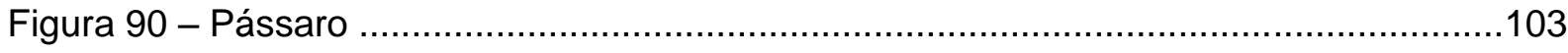

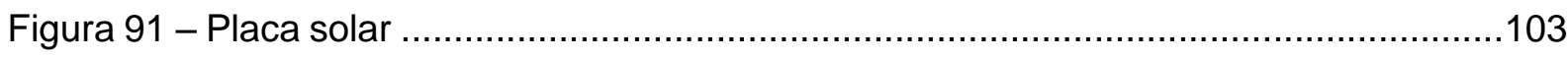

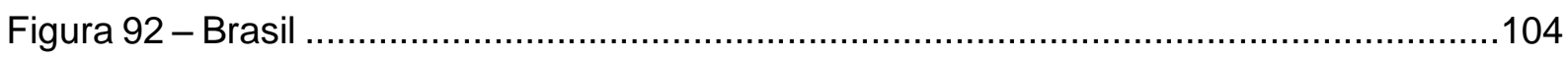

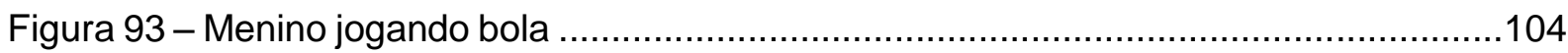

Figura 94 - Desenhos de observação sobre as auroras ................................................106

Figura 95 - Desenhos de observação sobre as auroras ................................................106

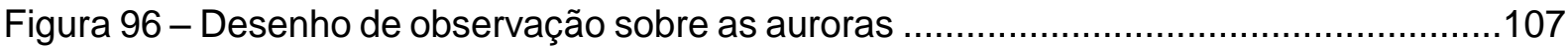

Figura 97 - Desenhos sobre as fases da Lua ...........................................................107

Figura 98 - Desenhos sobre as fases da Lua ..........................................................107

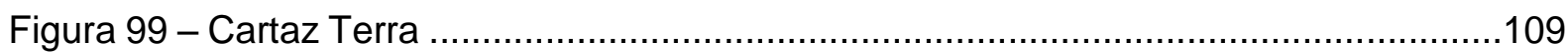

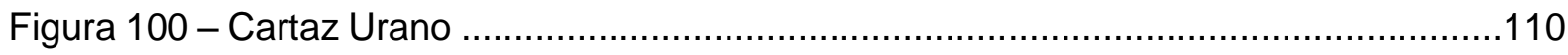

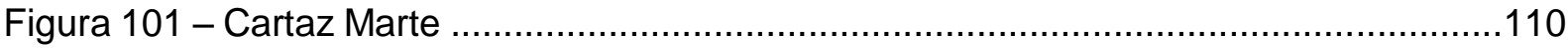

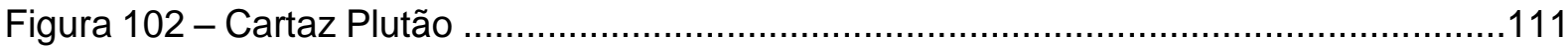

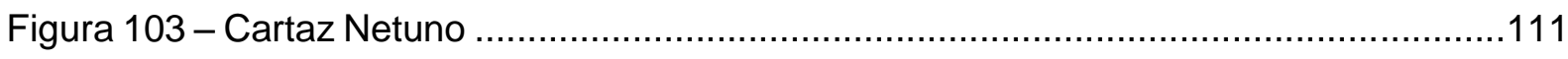

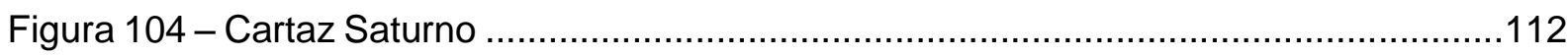

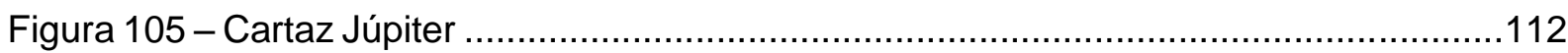

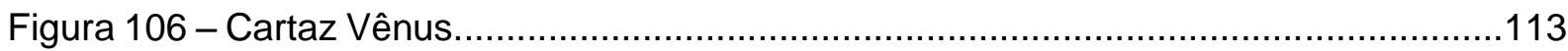


Figura 107 - Cartaz Mercúrio 113

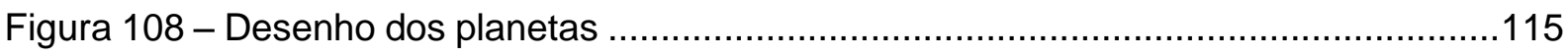

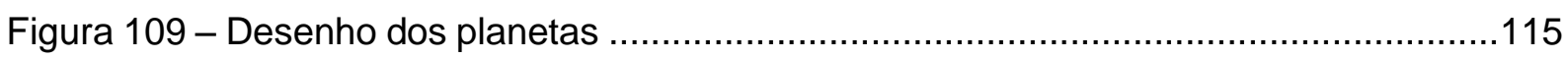

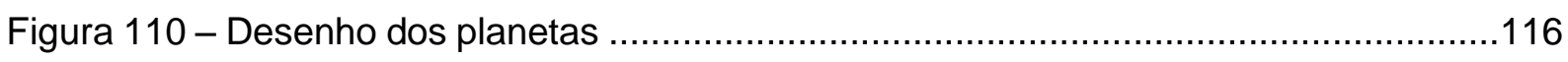

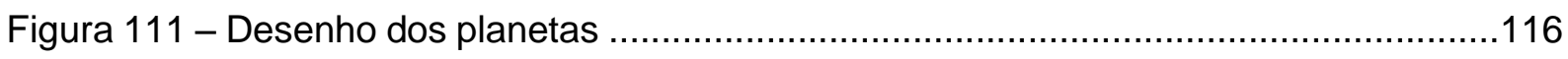

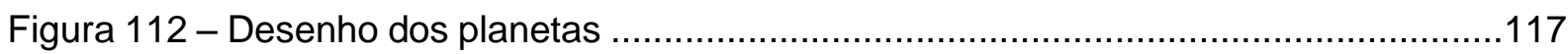

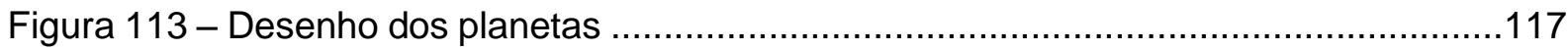

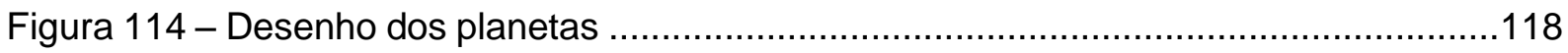

Figura 115 - Resposta questão 2 após a SD ...........................................................121

Figura 116 - Resposta questão 2 após a SD ..........................................................121

Figura 117 - Resposta questão 2 após a SD ..........................................................121

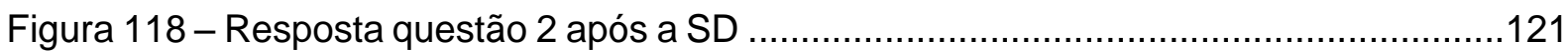

Figura 119 - Resposta questão 2 após a SD ................................................................121

Figura 120 - Desenho antes e depois da SD (Terra-Sol-Lua) ...........................................125

Figura 121 - Desenho antes e depois da SD (Terra-Sol-Lua) ............................................125

Figura 122 - Desenho antes e depois da SD (Terra-Sol-Lua) ..........................................126

Figura 123 - Desenho antes e depois da SD (Terra-Sol-Lua) ..........................................126

Figura 124 - Desenho antes e depois da SD (Terra-Sol-Lua) ..........................................127

Figura 125 - Desenho antes e depois da SD (Terra-Sol-Lua) .........................................128

Figura 126 - Desenho antes e depois da SD (Terra-Sol-Lua) ..........................................128

Figura 127 - Desenho antes e depois da SD (Terra-Sol-Lua) ............................................129

Figura 128 - Desenho antes e depois da SD (Terra-Sol-Lua) ...........................................129

Figura 129 - Desenho antes e depois (Onde você está no planeta?) .................................130

Figura 130 - Desenho antes e depois (Onde você está no planeta?) ...................................130

Figura 131 - Desenho antes e depois (Onde você está no planeta?) ...................................131

Figura 132 - Desenho antes e depois (Onde você está no planeta?) ..................................131

Figura 133 - Desenho antes e depois (Outros corpos celestes que conhece) ......................132

Figura 134 - Desenho antes e depois (Outros corpos celestes que conhece) .....................133

Figura 135 - Desenho antes e depois (Outros corpos celestes que conhece) .....................133

Figura 136 - Desenho antes e depois (Outros corpos celestes que conhece) ......................134

Figura 137 - Desenho antes e depois (Outros corpos celestes que conhece) .....................134

Figura 138 - Desenho antes e depois (Outros corpos celestes que conhece) .....................135

Figura 139 - Desenho antes e depois (Outros corpos celestes que conhece) .....................135 


\section{LISTA DE TABELAS}

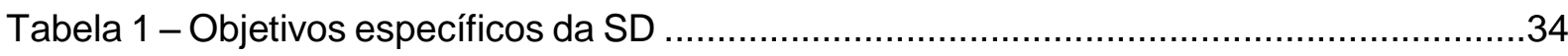

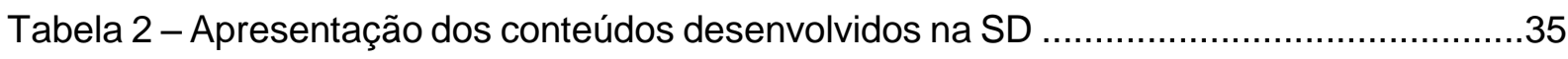

Tabela 3 - Apresentação das dinâmicas desenvolvidas na SD ...........................................37

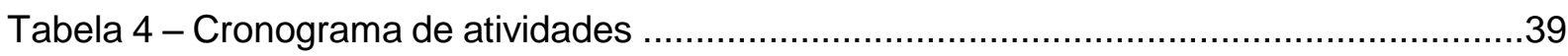

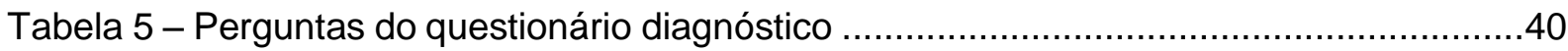

Tabela 6 - Respostas dos estudantes na questão 3 do questionário diagnóstico ....................87

Tabela 7 - Respostas incorretas dos estudantes na questão 4 do questionário diagnóstico

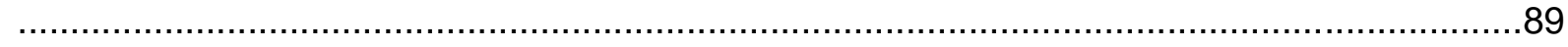

Tabela 8 - Respostas dos estudantes na questão 5 do questionário diagnóstico.....................89

Tabela 9 - Respostas dos estudantes na questão 8 do questionário diagnóstico.....................90

Tabela 10 - Pesquisas realizadas pelos alunos sobre mitos que contam a origem do mundo

Tabela 11 - Comparativo da questão 1 a antes e depois da SD ..........................................119

Tabela 12 - Comparativo da questão $1 \mathrm{~b}$ antes e depois da SD .......................................120

Tabela 13 - Comparativo da questão 2 antes e depois da SD .........................................120

Tabela 14 - Comparativo da questão 3 antes e depois da SD .........................................122

Tabela 15 - Comparativo da questão 4 antes e depois da SD ..........................................122

Tabela 16 - Comparativo da questão 5 antes e depois da SD ..........................................123

Tabela 17 - Comparativo da questão 6 antes e depois da SD ..........................................123

Tabela 18 - Comparativo da questão 7 antes e depois da SD ..........................................123

Tabela 19 - Comparativo da questão 8 antes e depois da SD ...........................................124

Tabela 20 - Reelaboração das aulas da SD ................................................................141 


\section{LISTA DE SIGLAS E ABREVIATURAS}

BNCC - Base Nacional Curricular Comum

EAR - Elaboração, Aplicação e Reelaboração

EF - Ensino Fundamental

EMEF - Escola Municipal de Ensino Fundamental

OBA - Olimpíada Brasileira de Astronomia e Astronáutica

PCN - Parâmetros Curriculares Nacionais

SEI - Sequência de Ensino Investigativa

SD - Sequência Didática

UE - Unidade Escolar 


\section{SUMÁRIO}

Capítulo 1 - 0 ensino de Astronomia nos anos iniciais …................................15

1.1 A importância do estudo de Astronomia nas séries iniciais ................................17

1.2 Os desafios de ensinar Astronomia nas séries iniciais .......................................20

1.3 A Base Nacional Curricular Comum (BNCC) e o compromisso com o ensino da Unidade Temática: Terra e Universo .................................................................................23

Capítulo 2 - A elaboração de Sequências Didáticas para o ensino de Astronomia

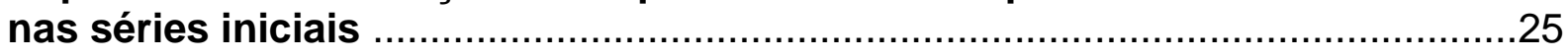

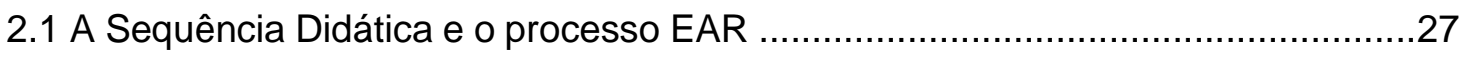

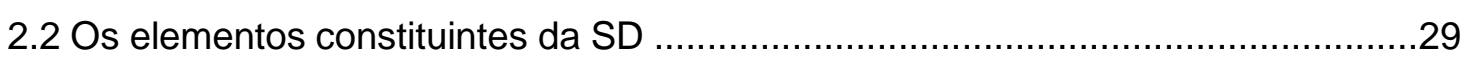

Capítulo 3 - A elaboração da Sequência Didática: Viagem pelo Sistema Solar...31

3.1 O contexto de aplicação e a caracterização da Unidade Escolar .............................32

3.2 A organização da Sequência Didática ...............................................................

Capítulo 4 - A aplicação da Sequência Didática ………....................................39

4.1 Aula 1 - Levantamento de conhecimentos prévios .............................................39

4.2 Aula 2 - Como surgiu o Universo? .................................................................. 41

4.3 Aula 3 - Nossa Galáxia: a Via Láctea. Onde está nosso Sistema Solar? ............46

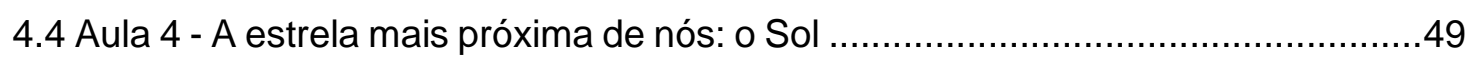

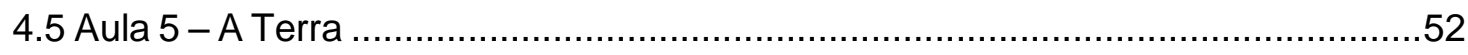

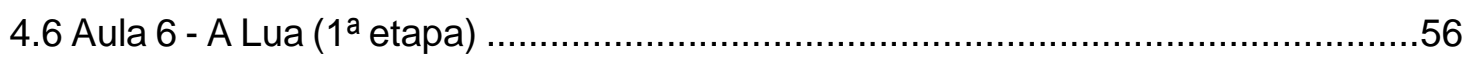

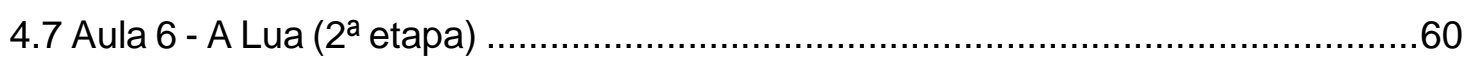

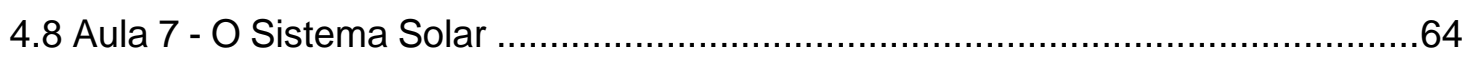

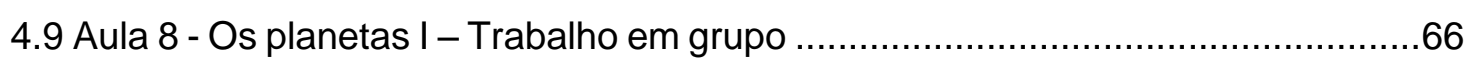

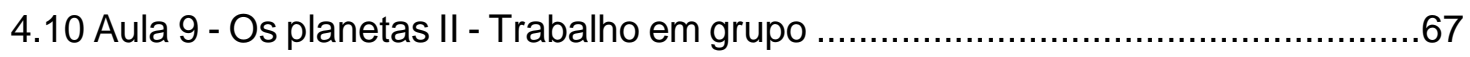

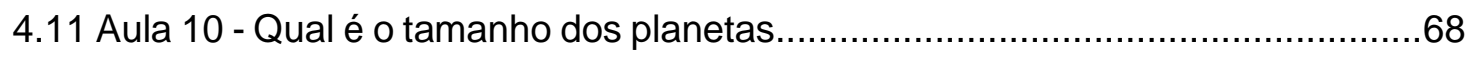

4.12 Aula 11 - Qual é a distância dos planetas? ......................................................74

4.13 Aula 12 - Um jogo sobre o Sistema Solar .....................................................77

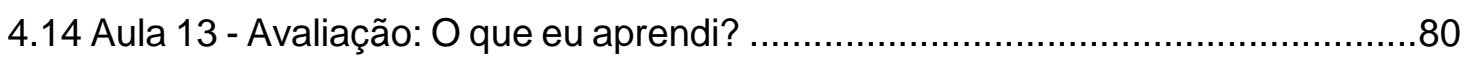

Capítulo 5 - Resultados da SD sobre o Sistema Solar .................................... 83

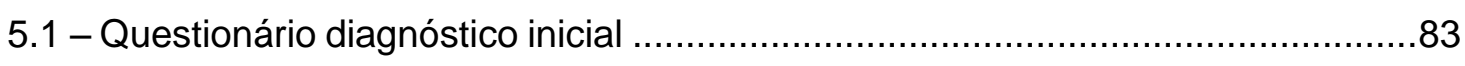

5.2 - Desenhos produzidos na atividade diagnóstica inicial .....................................92

5.3 - Análise das tarefas e pesquisas encaminhadas aos estudantes durante a

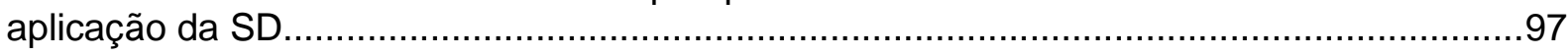

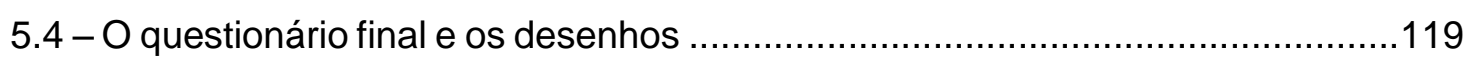


Capítulo 6 - Reelaboração da SD e conclusão

Referências 143

APÊNDICE: Material de apoio - Sequência Didática "Viagem pelo Sistema Solar" 


\section{Capítulo 1 - 0 ensino de Astronomia nos anos iniciais}

A Astronomia é uma das ciências mais antigas. A observação dos astros brilhantes no céu noturno tem povoado a imaginação de nossos antepassados, que por meio de histórias deram-Ihes diferentes significados e explicações. Os registros iniciais datam de aproximadamente 3000 a.C., e naquela época os astros eram estudados com objetivos práticos, como medir a passagem do tempo por meio da construção de calendários, a fim de prever a melhor época para plantio e colheita, além das previsões do futuro, associadas à astrologia, que atribuía significados aos fenômenos naturais pela influência de deuses (OLIVEIRA; SARAIVA, 2013, p. 1).

Com o passar do tempo a Astronomia foi se transformando, evoluindo, e seus objetivos práticos engendraram observações e debates mais aprofundados, num longo e complexo processo de estabelecimento de paradigmas, desconstrução e renovação dos mesmos. Um exemplo disso é a questão do geocentrismo que, a despeito das observações de Aristarco de Samos (310 a.C. - 230 a.C.) de que a Terra girava ao redor do Sol (PICAZZIO et al., 2011), predominou como paradigma durante toda a Antiguidade e Idade Média. Esse princípio foi superado apenas no século XVI, quando Nicolau Copérnico resgatou as ideias sugeridas por Aristarco, propondo o modelo heliocêntrico (OLIVEIRA; SARAIVA, 2013).

Aprimorando o telescópio, em 1610, Galileu Galilei apresentou importantes descobertas, como as quatro luas de Júpiter, as manchas solares, as crateras da Lua, entre outros, ampliando a compreensão do ser humano sobre o Universo. "A Astronomia moderna foi sendo consolidada, com as contribuições de Johannes Kepler, Tycho Brahe, Isaac Newton e, mais recentemente, William Herschel já no século 19 e Albert Einstein e Edwin P. Hubble, no século 20" (PICAZZIO et al., 2011).

A Astronomia atualmente faz parte do cotidiano do ser humano e suas inúmeras pesquisas têm revolucionado o modo como vivemos. Damineli e Steiner (2010, p.13) explicam que as ciências do universo estão prontas para dar um salto na história da civilização, ressaltando que a Astronomia se desdobrou em Astrofísica, Cosmologia, Astrobiologia, Planetologia e em muitas outras especializações dado a grande complexidade desse imenso laboratório formado por estrelas e galáxias.

Desta forma, a Astronomia vem revelando constantes descobertas, graças à invenção de equipamentos cada vez mais sofisticados para observação e por isso, 
tem sido amplamente divulgada nos meios de comunicação, adentrando o "universo" escolar.

Os alunos curiosos trazem a sala de aula questionamentos sobre o Universo, potencializando a proposta de um ensino focado na Astronomia. Para Viegas (2000),

\begin{abstract}
"Desde tempos imemoriais o céu exerce atração sobre as pessoas, seja pela beleza de um dia ensolarado, pelo feitiço de uma tempestade ou pelo encanto de uma noite límpida e estrelada. Nossos olhos sempre se voltam para o céu, que suscita nossa curiosidade, imaginação e busca pelo conhecimento. E daí vêm as perguntas que, no fundo, estão relacionadas com duas preocupações básicas da humanidade: a origem da vida e a origem do universo."
\end{abstract}

Assim, como destaca a autora, o encantamento pelo céu ocorre desde "tempos imemoriais", e sua abordagem nas séries iniciais do Ensino Fundamental destaca-se, pois como afirma Lago et al. (2017, p. 14) "a curiosidade 'astronômica', por querer desvendar os fenômenos que acontecem dentro e fora do nosso planeta, representa um grande potencial educativo", revelando-se como uma alternativa para ampliar os conhecimentos acerca do planeta em que vivemos, bem como, buscar compreender seus fenômenos, favorecendo o interesse dos alunos para aprofundar o estudo da Ciência, e consolidar seu contato com os procedimentos próprios de "fazer ciência", como "observar, formular hipóteses, experimentar, registrar, sistematizar, analisar, criar... e transformar o mundo" (PAVÃO e FREITAS, 2017, p.15), além de propiciar aos estudantes a reflexão e o contato com o fazer científico (LONGHINI 2014, p.12); portanto, está diretamente ligado a estudar Ciência, nos proporcionando uma forma de conhecer e entender o mundo que habitamos, e ainda assim, ser capaz de extasiar aqueles que a constroem, como aqueles que passam a ter a oportunidade de compreendê-la (SASSERON; MACHADO, 2017a, p. 9).

No entanto, Langhi e Nardi (2012), afirmam que o ensino de Astronomia possui algumas particularidades que o diferencia de outras áreas, pois seu campo de estudo está além do que podemos enxergar, ou ainda, o que observamos a olho nu nem sempre são suficientes para explicar um fenômeno astronômico corretamente, o que dificulta a elaboração de esquemas mentais e nossa capacidade de imaginar. Vários fenômenos observados no Universo não são identificados na Terra, e quando reproduzidos em laboratórios, exigem grande abstração. O estudo de Astronomia ainda necessita da prática constante de observação, pesquisa e estudo das 
informações contidas na literatura. Isto posto, se faz necessário justificar porque estudar Astronomia já nas séries iniciais é fundamental.

\subsection{A importância do estudo de Astronomia nas séries iniciais}

Pavão e Freitas (2017, p.15), afirma que "ensinar ciências nas séries iniciais não é uma tarefa difícil." $O$ autor ressalta que o segredo está na percepção do professor ao aproveitar aquilo que é natural nos alunos: o desejo de conhecer, agir, dialogar, interagir e experimentar. Um ambiente em que se proporciona aos estudantes esta oportunidade, favorece a aquisição da "Alfabetização Científica". Mas, afinal o significa "Alfabetização Científica"?

O termo Alfabetização Científica tem sido constantemente abordado entre teóricos, e seu significado aponta para diversos esclarecimentos semelhantes (MATTHEWS 1994; AULER \& DELIZOICOV, 2001; LORENZETTI \& DELIZOICOV, 2001; CHASSOT, 2003; DÍAZ et al., 2003), além de variações do termo, como "Letramento Científico" e "Enculturação Científica" (SASSERON; MACHADO, 2017; BRASIL, 2018).

Para Chassot (2003, p. 91) "ser alfabetizado cientificamente é saber ler a linguagem em que está escrita a natureza. É um analfabeto científico aquele incapaz de uma leitura do universo". Desta maneira, concebe-se que um indivíduo alfabetizado cientificamente é capaz de entender a linguagem da Ciência, debatê-la e refletir sobre seus processos. No entanto, esta frase de Chassot (2003) nos remete a buscar construir primeiro o significado da palavra alfabetização, que no entender de Soares (2010, p.36) é,

\footnotetext{
a pessoa que aprende a ler e a escrever - que se torna alfabetizada e que passa a fazer uso da leitura e da escrita, a envolver-se nas práticas sociais de leitura e escrita - que se torna letrada - é diferente de uma pessoa que não sabe ler e escrever - é analfabeta - ou, sabendo ler e escrever, não faz uso da leitura e da escrita - é alfabetizada mas não é letrada.
}

De acordo com a autora, para ser alfabetizado o sujeito deve ser capaz de ler e escrever, e conforme este indivíduo passa a fazer uso das práticas sociais da leitura e escrita, torna-se letrado. Sasseron e Carvalho (2011, p. 61), destacam que uma pessoa alfabetizada possui a "capacidade de organizar seu pensamento de maneira 
lógica, além de auxiliar na construção de uma consciência mais crítica em relação ao mundo que a cerca". Paulo Freire (1967) destaca que a alfabetização ultrapassa a técnica mecânica de escrever e de ler. O autor explica que estar alfabetizado é ter o domínio dessa técnica de forma consciente e poder comunicar-se graficamente, e isto "implica numa autoformação de que possa resultar uma postura interferente do homem sobre seu contexto" (p.110).

Partindo do pressuposto de uma postura "interferente" do homem, pode-se interpretar que o termo alfabetização é o processo que permite ao ser humano conceber o mundo que o cerca de forma crítica e participativa.

Expandindo para o enfoque do termo "alfabetização", para "alfabetização científica", nos deparamos com a interpretação, segundo Lorenzetti (2001) de que trata-se da "capacidade de ler, compreender e expressar opinião sobre os assuntos que envolvam a Ciência", mas para o autor não é só isso, uma vez que para o indivíduo desenvolver uma alfabetização científica ele não precisa necessariamente dominar o código escrito, embora ela possa influenciar positivamente na conquista do domínio da leitura e escrita.

Sendo assim, se faz necessário procurar entender o que significa ser alfabetizado cientificamente. Sasseron e Machado (2017) adotam o termo alfabetização científica para denominar o ensino de Ciências que apresenta o objetivo de formar um indivíduo capaz de resolver problemas de seu cotidiano, levando em conta os saberes adquiridos sobre o estudo das Ciências e as metodologias próprias do campo científico. Consequência disso é "o aluno ser capaz de tomar decisões fundamentadas em situações que ocorrem ao seu redor e que influenciam, direta ou indiretamente, sua vida e seu futuro" (p. 11).

Corrobora a esta concepção o novo documento destinado a área de Ciências da Natureza, da Base Nacional Curricular Comum (BNCC), no qual menciona-se o termo Letramento Científico, que valida o que discutimos até aqui sobre a Alfabetização Científica, pois de acordo com o documento, o ensino de Ciências só se justifica se a educação formal assumir o compromisso com a formação integral dos alunos, e para isso, se faz necessário, "o compromisso com o desenvolvimento do letramento científico, que envolve a capacidade de compreender e interpretar o mundo (natural, social e tecnológico), mas também de transformá-lo com base nos aportes teóricos e processuais das ciências" (BRASIL, 2017, p. 319). 
Neste sentido, considera-se o estudo da Astronomia como uma alternativa para o incentivo e a prática da alfabetização científica, a fim de favorecer que os estudantes participantes tenham assegurado por meio das atividades desenvolvidas um novo olhar sobre o mundo que os cerca, e possam refletir sobre suas escolhas, compreendendo que elas apresentam consequências mundiais, e que estas podem interferir diretamente na qualidade de vida de todos os habitantes do planeta.

É possível citar outros aspectos fundamentais para justificar o ensino de Astronomia. Longhini (2014, p. 18) ressalta que a introdução do estudo desse tema na Educação Básica propicia ao aluno um melhor entendimento do mundo em que vive e também da compreensão de como o conhecimento científico foi construído.

Langhi e Nardi (2012) salientam que a educação em astronomia justifica-se por esta participar de nossas vidas de forma intensa, devido à observação dos fenômenos naturais que ocorrem no planeta, como por exemplo, a sucessão dos dias e das noites; a compreensão da contagem de um ano; a formação das estações do ano; o movimento aparente do Sol; as fases da Lua; a formação dos eclipses, entre outros. A curiosidade fomentada pelos meios de comunicação, ofertando diversos tipos de notícias espaciais, bem como, a produção de filmes de ficção científica, adentram o espaço escolar com perguntas e questionamentos que podem ser disparadores para temas de aula. $\mathrm{O}$ avanço tecnológico também aponta sobre os estudos espaciais que passam a fazer parte de nosso cotidiano.

A Astronomia também busca respostas sobre a origem de toda a humanidade, do espaço, e naturalmente aguça a curiosidade em descobrir: Quem somos? De onde viemos? Para onde vamos? Há vida além da que constatamos na Terra? A busca por estas explicações, pode levar a debates mais relevantes sobre a preservação do planeta, e a reflexão sobre nossa pequenez diante da imensidão Universo (BRETONES, 2013).

Outro enfoque que favorece o ensino de Astronomia é que ela é naturalmente interdisciplinar (LANGHI; NARDI, 2012), favorecendo seu estudo em diversas áreas do conhecimento, oferecendo sentido ao que se estuda. Bartelmebs e Moraes (2012, p. 344) ressaltam que,

Uma das principais características da Astronomia é a interdisciplinaridade. Dentro de seus temas de estudos é possível desenvolver muitas possibilidades de conhecer o mundo. $O$ trabalho em sala de aula com conteúdos de Astronomia pode ser muito rico e 
significativo, pois essa ciência permite relações com as mais variadas disciplinas do currículo escolar. Isso pode despertar o interesse pela pesquisa e pelo saber.

A interdisciplinaridade é favorecida nas séries iniciais, pois o professor regente é responsável por ministrar a maioria das disciplinas, promovendo em seu planejamento a interação entre elas, além de facilitar parcerias com professores especialistas.

Além disso, estudar Astronomia possui um custo baixo na elaboração de experimentos, e seu laboratório está a céu aberto, já que para compreender os fenômenos são necessárias as práticas de observação (LANGHI; NARDI, 2012; LONGHINI, 2014). Atualmente já se encontram aplicativos e softwares para observar o céu noturno, além de materiais específicos para seu estudo e atividades práticas guiadas, inclusive incentivando os estudantes a participarem da Olimpíada Brasileira de Astronomia e Astronáutica (OBA).

E por fim, pode-se citar a obrigatoriedade do estudo da Unidade Temática "Terra e Universo" desde o 1a ano da Educação Básica, por meio da homologação da Base Nacional Curricular Comum (BNCC), nos revelando a necessidade de tratar de seus assuntos com mais afinco e profundidade.

\subsection{Os desafios de ensinar Astronomia nas séries iniciais}

Um aspecto dificultador é a formação docente deficiente (LANGHI, 2012; BRETONES, 2013; LONGHINI, 2014). Estudos afirmam que os professores adentram as escolas com o pouco conhecimento adquirido enquanto estudantes da educação básica. Langhi (2004, p.7), nos aponta que,

O panorama geral histórico do ensino da Astronomia no Brasil demonstra o quanto esta Ciência tem se afastado gradualmente dos currículos escolares, a tal ponto de praticamente inexistir em cursos de formação de professores, notadamente do Ensino Fundamental e dos anos iniciais. A existência desta deficiência na formação docente geralmente implica em geração de dificuldades neste tema durante 0 seu ensino de Ciências para os estudantes.

Devido ao ensino de Astronomia ser insuficiente nos cursos de formação de professores, Langhi e Nardi (2012) salientam que na formação dos professores das 
séries iniciais este aspecto se agrava, visto que seus estudos apontam falta de domínio para ensinar conceitos básicos de Astronomia, como as causas do dia e da noite ou das estações do ano. Em outras pesquisas realizadas, os autores citam que "professores criticam sua formação falha em conteúdos de Astronomia e que ficam surpresos diante de erros de livros didáticos" (p. 96).

Diante disso, a dificuldade apresentada na formação docente reflete no desinteresse dos estudantes acerca dos conteúdos de Ciências, principalmente no que se refere aos estudos de Astronomia (BRETONES, 2013; LANGHI, NARDI; 2012).

Bretones (1999), afirma que a astronomia é observada de maneira superficial nos programas de Ciências ou Geografia do Ensino Fundamental (EF), além de ter seus conteúdos presentes em outras áreas. O autor relata que "se fizermos uma análise mais apurada, veremos que ela tem potencialidades muito maiores, os quais têm sido desperdiçadas e, ao nosso ver, muitas vezes também desprezadas" (p.1).

Devido à formação docente ser insuficiente, os professores buscam informações presentes em livros didáticos, o que na maioria das vezes, concentra-se no único recurso didático à disposição do professor. O problema é que os livros didáticos estão repletos de equívocos, desenhos incorretos e informações incompletas. Dissemina-se assim, ideias incoerentes entre os estudantes. "Há ainda que acrescentar que os livros didáticos falham no aspecto da motivação à observação prática, deixando de incentivar o aluno à análise dos fenômenos do céu, no seu diaa-dia" (LANGHI, 2005).

Bretones (1999, p.2) critica que também o "professor muitas vezes 'é adotado' pelo livro ao invés do livro ser adotado pelo professor", levando-o a dedicar-se às explicações disponíveis neles, e assim disseminar informações inadequadas.

O grande problema ao se propagar informações inadequadas apoiadas nos erros conceituais dos livros didáticos ou nas explicações insuficientes abordadas neles é a construção de concepções alternativas entre os estudantes. Langhi (2011) ressalta que concepções alternativas apresentam diversas nomenclaturas, como ideias intuitivas, concepções prévias, baseadas no senso comum. Em outras palavras são conhecimentos baseados na observação, que diante de estudos e sua compreensão tornam-se conhecimentos científicos.

Todo indivíduo no processo de aprendizagem carrega concepções alternativas que mediante as suas experiências e estudos consegue torná-la conhecimento 
verdadeiro. O grande problema apontado por Langhi (2011) é que entre os professores estas concepções alternativas persistem, e que eles ensinam de acordo com estas crenças. Um exemplo deste estudo foi apontado por Langhi e Nardi (2012), de que baseados em informações presentes nos livros didáticos alguns professores e alunos acreditam que "O Sol é uma bola de fogo; Ao meio-dia não há sombra, pois o Sol está a pino; Que a Lua possui quatro fases; Que as estações do ano ocorrem devido à variação de distância da Terra em relação ao Sol, entre outros" (p. 101-103). Diante disso, se faz emergente modificar este cenário nacional. Langhi (2005) afirma que os professores reconhecem suas dificuldades com o ensino de Astronomia e expressam o seu gosto pelo tema, e lamentam sua capacidade limitada de ensiná-lo.

Outro aspecto preocupante são os materiais elaborados para o tema, disponíveis na internet. Deparamo-nos com "cruzadinhas do Sistema Solar" ou jogos de memória, todos muito "infantilizados". Não raro encontramos figuras em que o Sol e a Lua aparecem com olhos e boca, geralmente deturpando o viés científico que o tema apresenta. Faz-se necessário um cuidado com a alfabetização científica, usando a terminologia correta, como destaca Bizzo (2002, p. 60),

\begin{abstract}
A terminologia científica, como vimos, deve ser entendida dentro de seu contexto, com seus significados compreendidos, e deve ser utilizada de forma correta, mesmo que de forma simplificada - mas nunca distorcida - para ser acessível aos estudantes de diferentes idades. O professor deve utilizar termos científicos progressivamente, verificando que sua correta compreensão esteja sempre presente.
\end{abstract}

Outro aspecto apontado por Langhi e Nardi (2012) está na falha das estratégias de ensino, que se assemelham mais com a memorização de conceitos, desestimulando os estudantes que enfrentam aulas com métodos desinteressantes, geralmente ficando no campo teórico e sendo inconsistente na prática. E mesmo a prática de observação noturna pode ser um agravante nas cidades, já que devido à poluição luminosa é possível observar bem menos estrelas do que o esperado.

O ensino de Astronomia também se manteve esmaecido durante anos, já que antes da publicação da BNCC, o documento que orientava a organização dos currículos era o PCN (Parâmetros Curriculares Nacionais). O documento era dividido em quatro blocos temáticos: Ambiente; Ser humano e saúde; Recursos tecnológicos; e Terra e Universo, destacando que o bloco Terra e Universo ficava destinado apenas 
a partir do terceiro ciclo, que compreende as séries do atual 6 ano. (BRASIL, 1997, p. 34).

Outro aspecto a se levar em consideração é que o campo de estudo da Astronomia perpassa o âmbito da Terra, dificultando o seu acesso físico, dependendo de um modo de interpretar e analisar dados. No ambiente escolar, é fundamental que o professor forneça imagens, softwares simuladores, maquetes e que produza materiais didáticos para fortalecer o seu ensino, o que nem sempre se identifica como prioridade, abandonando a Astronomia para segundo plano, ou com estudo superficial que conduz a elaborar nos estudante mais concepções alternativas, não garantindo uma aprendizagem significativa e verdadeira.

1.3 A Base Nacional Curricular Comum (BNCC) e o compromisso com o ensino da Unidade Temática: Terra e Universo

A BNCC foi homologada em 20 de dezembro de 2017, e é o documento que define as aprendizagens essenciais que todos os alunos têm o direito de aprender, ao longo de seus estudos, até o final da Educação Básica. Este documento é referência nacional e obrigatório para a formulação dos currículos dos sistemas de educação. Seus propósitos são a formação humana integral, a fim de construir uma sociedade justa, democrática e inclusiva (BRASIL, 2017).

O documento é definido por Competências Gerais correspondentes a todas as áreas do conhecimento, e complementado com as competências e habilidades específicas divididas por áreas. Vale salientar que a Competência Geral 2 suscita,

\footnotetext{
Exercitar a curiosidade intelectual e recorrer à abordagem própria das ciências, incluindo a investigação, a reflexão, a análise crítica, a imaginação e a criatividade, para investigar causas, elaborar e testar hipóteses, formular e resolver problemas e criar soluções (inclusive tecnológicas) com base nos conhecimentos das diferentes áreas. (Brasil, 2017, p.11)
}

Esta competência pode facilmente perpassar os estudos da área de Ciências da Natureza, corroborando para uma aprendizagem mais integral, o qual tratamos na introdução deste capítulo sobre o desenvolvimento da alfabetização científica.

$\mathrm{Na}$ área de Ciências da Natureza, apresenta-se um ganho no que diz respeito ao ensino de Astronomia para as sérias iniciais. A unidade temática Terra e Universo 
é garantida desde $01^{\circ}$ ano, elucidando o estudo de objetos de conhecimento essenciais, tais como: Escalas de tempo; Movimento aparente do Sol no céu; O Sol como fonte de luz e calor; Características da Terra; Observação do céu; Usos do solo; Pontos cardeais; Calendários, fenômenos cíclicos e cultura; Constelações e mapas celestes; Movimento de rotação da Terra; Periodicidade das fases da Lua e Instrumentos ópticos (BRASIL, 2017, p. 332-341).

O desafio que se coloca aos sistemas de educação e aos educadores diante da homologação da BNCC não é meramente normativo, mas sim, o de buscar formação e conhecimento a fim de proporcionar um ensino adequado e de qualidade, que seja capaz de investir mais do que em aulas expositivas e leituras de textos em livros didáticos.

Sabendo do panorama nacional sobre os conhecimentos ofertados na formação de professores sobre os assuntos de Astronomia, faz-se emergente a construção de materiais de formação (que é um dos objetivos do presente trabalho) e a formação contínua de professores. Além disso, devem-se rever algumas práticas de ensino, já que a BNCC menciona o enfoque de um ensino voltado para "atividades investigativas, bem como no compartilhamento de resultados dessas investigações" (BRASIL, 2017, p. 319), e isso consiste em propor situações de aprendizagem desafiadoras, que estimulem a curiosidade científica dos alunos, instigando seu interesse, proporcionando um ambiente educativo que possibilitem definir problemas, levantar hipóteses, analisar resultados e comunicar o que aprenderam (BRASIL, 2017), promovendo uma educação voltada para o ensino da Ciência, não com a finalidade de formar cientistas, mas sim, de formar um indivíduo capaz de compreender o mundo em que vive garantindo o pleno direito que todos devem ter. 


\section{Capítulo 2 - A elaboração de Sequências Didáticas para o ensino de Astronomia nas séries iniciais}

Uma das mais importantes atribuições de um professor é garantir a aprendizagem significativa de seus alunos. Ronca (1994, p.92) entende aprendizagem significativa como um processo cognitivo no qual a mediação está presente, e para que a aprendizagem obtenha este caráter é necessário que se estabeleça uma relação entre o conteúdo a ser aprendido com aquilo que o aluno já sabe.

Assim, a valorização das ideias prévias que os estudantes trazem acerca do que lhes é proposto em sala de aula, é fundamental para a relacionarmos às intenções de ensino (PAVÃO e FREITAS, 2017).

Procurando focar a aprendizagem significativa, no desenvolvimento de uma alfabetização científica, a BNCC nos apresenta uma reflexão relevante acerca deste aspecto. $O$ documento ressalta que já na Educação Infantil os estudantes exploram os ambientes e seus fenômenos, em todos os campos de experiências. Ao adentrarem no Ensino Fundamental "os alunos possuem vivências, saberes, interesses e curiosidades sobre o mundo natural e tecnológico que devem ser valorizados e mobilizados" (BRASIL, 2017, p. 151). E dessa maneira, é fundamental planejar atividades e situações de aprendizagem que permitam aos estudantes se desenvolverem, ampliando o que já sabem e deparando-se com novos desafios.

Sendo assim, acreditamos em um ensino de Ciências que valorize o protagonismo infantil, bem como, oportunizar aos estudantes momentos de investigação, possibilitando sistematizar e ampliar seus conhecimentos.

O ensino por investigação é pesquisado por Sasseron e Machado (2017, p. 27), e os autores explicam que "para que uma atividade seja investigativa, é preciso enfatizar o importante papel do professor, cujo trabalho é problematizar o conteúdo e incentivar a resolução de problemas fazendo uso da linguagem científica". Os autores ainda ressaltam que uma atividade do cotidiano da sala de aula pode se transformar em uma atividade investigativa, desde que o professor procure manter uma postura dialogada, elaborando perguntas (que proporcionem investigação) que possibilitem os estudantes a participarem do processo.

Reforça-se com esta ideia a prática de Sequências de Ensino Investigativas (SEI), sugerida por Carvalho (2013), que consiste em planejar cada atividade, tanto 
material como das interações didáticas, visando proporcionar aos alunos "condições de trazer seus conhecimentos prévios para iniciar os novos, terem ideias próprias e discuti-las com seus colegas e com o professor passando do conhecimento espontâneo ao científico..." (p. 9).

Carvalho (2013) reforça que uma SEI se inicia a partir de um problema, que introduz os alunos no tema desejado e oferece condições para que eles reflitam sobre as variáveis relevantes do fenômeno; por conseguinte a atividade deve sistematizar o conhecimento construído, de preferência por meio de um texto onde os alunos podem confrontar sua aprendizagem com o texto em questão; a atividade final deve propor uma contextualização do conhecimento adquirido no dia a dia, para que os estudantes compreendam a importância da aplicação do que aprenderam do ponto de vista social (CARVALHO, 2017, p. 9).

De modo geral, a prática docente depende de estudo, planejamento, escolha de metodologias e a gestão adequada do tempo. Dentre todos estes aspectos citados, o tempo é o grande desafio do professor no momento de fazer escolhas entre o que se pretende ensinar e o resultado que irá alcançar diante do tempo que lhe cabe em sala de aula.

Uma das alternativas para suprir essa dificuldade em organizar as prioridades a serem trabalhadas em sala de aula é refletir sobre as práticas de ensino. Não basta apenas pensar nos conteúdos, e sim, em como eles serão abordados e avaliados.

Nesse contexto, Zabala (1998, p. 20) nos apresenta uma reflexão interessante,

(...) as sequências de atividades de ensino/aprendizagem, ou sequências didáticas, são uma maneira de encadear e articular as diferentes atividades ao longo de uma unidade didática. Assim, pois, poderemos analisar as diferentes formas de intervenção segundo as atividades que se realizam e, principalmente, pelo sentido que adquirem quanto a uma sequência orientada para a realização de determinados objetivos educativos. As sequências podem indicar a função que tem cada uma das atividades na construção do conhecimento ou da aprendizagem de diferentes conteúdos e, portanto, avaliar a pertinência ou não de cada uma delas, a falta de outras ou a ênfase que devemos lhe atribuir.

Considerando as ideias do autor, acreditamos que a melhor alternativa para otimizar o tempo e de fato organizar os conteúdos didáticos é a organização de sequências de atividades/didáticas, que propiciem a investigação, de modo a garantir 
uma aprendizagem mais plena e consciente. Giordan et al. (2012, p. 10) destacam que a Sequência Didática (SD) possui diversas perspectivas, das quais são as principais aquelas em que a SD é tratada como instrumento de planejamento do ensino e também como objeto de pesquisa da prática docente.

Para Giordan e Guimarães (2013) a SD é um instrumento que descreve as ações da prática docente em sala de aula e que consiste numa perspectiva sociocultural como uma alternativa eficiente para minimizar um ensino fragmentado e descontextualizado.

A SD possui um conjunto de atividades articuladas e organizadas de forma sistemática e com desencadeamento lógico, em torno de uma problematização, que é planejada previamente pelo professor. A SD ainda se revela como instrumento poderoso, pois por meio dela se desencadeiam diversas ações e operações a serem realizadas em sala de aula. Em consequência, o planejamento da estrutura e a dinâmica da SD são fundamentais para o sucesso de sua realização, já que por meio dela, os estudantes vão interagir entre si e com os elementos da cultura, e apropriarse dos conhecimentos (GIORDAN; GUIMARÃES, 2012).

Um ponto importante ressaltado pelos autores é que na elaboração e desenvolvimento da SD, o foco do professor deve estar voltado para o processo e não apenas no resultado da aprendizagem (GIORDAN; GUIMARÃES, 2012).

Neste trabalho, escolhemos como premissa o eixo teórico de validação de SD que consiste num processo cíclico em que se analisa e avalia cada etapa de Elaboração, Aplicação e Reelaboração, denominado processo EAR (Giordan e Guimarães, 2013).

\subsection{A Sequência Didática e o processo EAR}

A SD não é vista apenas como uma sequência de atividades que são aplicadas em sala de aula. Giordan e Guimarães (2013) explicam que o ideal é que a SD seja elaborada e validada por meio de um longo processo de análise sistematizada e avaliações consecutivas, pensando em cada elemento que compõe a SD, desde seu contexto de aplicação, seus resultados e sua relação com o plano anual de ensino da escola. Ou seja, trata-se de um trabalho minucioso. Os autores também destacam que 
ela tem uma abordagem sociocultural, que significa que é constituída com a participação e interação de todos.

O processo EAR, consiste em Elaborar, Aplicar e Reelaborar a SD (GIORDAN; GUIMARÃES, 2012). A seguir procuraremos esclarecer cada uma destas etapas.

A Elaboração baseia-se em planejar e organizar a SD, para que ela oriente a ação docente, bem como o planejamento de suas estratégias de ação. Para isto é fundamental que se registre os seguintes componentes em seu planejamento: Título; Público Alvo; Problematização; Objetivo Geral; Objetivo Específico; Conteúdos; Dinâmica; Avaliação; Referências Bibliográficas e Material utilizado (GIORDAN; GUIMARÃES, 2012).

O embasamento da elaboração deve contemplar uma abordagem sociocultural, na perspectiva de que o aluno assimila os conhecimentos segundo a interação social (Vygotski, 1991).

Após a elaboração, o docente inicia a fase de Aplicação, composta por quatro etapas, sendo que três são realizadas antecipadamente à aplicação da SD, e a última consiste na aplicação das atividades planejadas em sala de aula. As três primeiras etapas já fazem parte do que Giordan e Guimarães (2012) constatam como validação. Inicialmente as três primeiras etapas de validação passam respectivamente pela avaliação de especialistas, professores da área e pelo professor coordenador. Em outras palavras, esse momento consiste na apreciação do documento elaborado por outros especialistas, a fim de estes participarem de sua construção, efetuando a leitura e sugerindo mudanças, adaptações e etc. Sendo assim, ao final deste processo a SD estará mais adequada, pois foi fruto de uma construção coletiva. A última etapa consiste na aplicação da SD em sala de aula. Essa fase é fundamental, já que nela serão coletados os dados de investigação.

Por fim, a última etapa do processo é a Reelaboração da SD. Segundo Giordan e Guimarães (2012), nesta etapa o professor já possui os resultados da aplicação da SD e agora pode confrontar seus objetivos quanto à elaboração realizada anteriormente. Neste momento o professor retorna à elaboração, realizando as modificações que sejam necessárias, agora imbuído de uma rica experiência. Esta fase é fundamental para que o docente possa aprimorar sua prática por meio da reflexão.

A seguir apresenta-se um esquema de cada fase do processo EAR: 


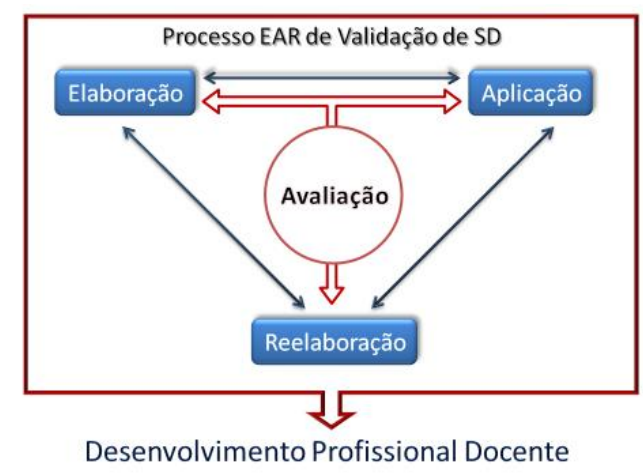

Figura 1 - Representação esquemática do Processo EAR. Fonte: Giordan e Guimarães (2013, p. 4)

Ao final do processo EAR o profissional docente se torna fortalecido, pois conforme suscitam Giordan e Guimarães (2012, p. 11), "nesta fase é essencial que se retorne ao início e reveja a elaboração da SD, não apenas para melhorar sua estrutura, mas principalmente a fim de reelaborar saberes profissionais do professor na construção e aplicação de estratégias de ensino".

\subsection{Os elementos constituintes da SD}

Com a finalidade de organizar e estruturar a SD, Giordan e Guimarães (2012) destacam a importância de organizar cada item cuidadosamente, a fim de auxiliar o professor na elaboração de suas ações e propósitos de ensino, os quais se resumem a seguir:

- Título

É um elemento importante, pois é capaz de atrair a atenção do público-alvo, ou, de forma contrária, desestimulá-los.

- Público-alvo (Caracterização dos alunos, da escola e do ambiente escolar) É um aspecto fundamental, mas desconsiderado em várias situações. Ele é fundamental ser pensado, pois nenhuma SD é universal, e cada uma deve ser planejada para a faixa etária adequada. Este tópico ainda se subdivide em três itens:

a) Caracterização dos alunos: Definir para qual público está sendo elaborada a SD, investigando um pouco de seus conhecimentos prévios e das necessidades sociais e cognitivas reais do grupo. 
b) Caracterização da escola: Informar o nome da escola, a estrutura que possui com descrição de números de alunos, salas de aula e outros espaços importantes para a realização da SD.

c) Caracterização do ambiente escolar: Deve abranger a localização bem como os aspectos socioculturais da escola, dos pais e da comunidade.

- Problematização

É a formulação do problema que a SD pretende desenvolver, pensando em sua essência social e científica.

- Objetivos (Geral e Específico)

a) O objetivo geral tem uma meta a ser atingida e se refere à aprendizagem ou desenvolvimento do aluno.

b) Os objetivos específicos são mais detalhados nos propósitos do ensino.

- Conteúdos

São organizados tradicionalmente de forma disciplinar, mas neste momento, podem ser repensados de forma a se conectar a outras áreas.

- Dinâmicas

São as metodologias utilizadas, e por isso é fundamental que sejam diversificadas para o desenvolvimento das situações de aprendizagem.

- Avaliação

A avaliação deve ser compatível com os objetivos e conteúdos, avaliando o que de fato se deseja ensinar.

- Bibliografia (Referencial teórico e material utilizado)

a) Referencial teórico: Trata-se da fundamentação teórica na qual a SD está apoiada e estruturada.

b) Material utilizado: Deve-se relacionar todo material utilizado como livros, vídeos, animações, jogos propostos nas atividades.

Por meio da organização destes itens, trataremos no próximo capítulo da elaboração da SD proposta neste trabalho. 


\section{Capítulo 3 - A elaboração da Sequência Didática: Viagem pelo Sistema Solar}

A escolha deste tema se deu em virtude da Unidade Temática "Terra e Universo", proposta na Base Nacional Curricular Comum (BNCC). No documento sugere-se que os alunos desde as séries iniciais conheçam os aspectos sobre a Terra, sua formação e que a observação de nossos alunos acerca da vida na Terra e a suposição de vida além perpasse as discussões em sala de aula.

Esta SD foi planejada para o $5^{\circ}$ ano do Ensino Fundamental, e aplicada a uma turma a qual a professora autora leciona. Foi escolhida esta forma de aplicação devido sua impossibilidade de se ausentar do trabalho para aplicá-la em outra UE.

As habilidades sugeridas pela BNCC (2017) para o 5ํaㅇ ano do Ensino Fundamental são:

a) Associar o movimento diário do Sol e das demais estrelas no céu ao movimento de rotação da Terra;

b) Concluir sobre a periodicidade das fases da Lua, com base na observação e no registro das formas aparentes da Lua no céu ao longo de, pelo menos, dois meses;

c) Identificar algumas constelações no céu, com o apoio de recursos, como mapas celestes e aplicativos, entre outros, e os períodos do ano em que elas são visíveis no início da noite;

d) Projetar e construir dispositivos para observação à distância (luneta, periscópio etc.), para observação ampliada de objetos (lupas, microscópios) ou para registro de imagens (máquinas fotográficas) e discutir usos sociais desses dispositivos. (p. 339)

A princípio esta SD irá contemplar os itens a, b e c, e será complementada com outros assuntos que julgamos pertinentes e que compõem a parte diversificada do currículo. Espera-se ampliar os conhecimentos dos estudantes, permitindo que elaborem questionamentos sobre a vida no planeta, e que reflitam sobre o que há fora deste espaço que ocupamos.

A escolha do tema da SD também ocorreu em virtude de a professora aplicadora constatar que o público alvo não teve contato desde o início de sua escolaridade no EF com assuntos relacionados à Astronomia.

A SD foi aplicada durante as aulas de Ciências, mas também foram utilizadas outras aulas, já que se trata de uma proposta interdisciplinar. 


\subsection{O contexto de aplicação e a caracterização da Unidade Escolar}

Esta SD foi aplicada na EMEF anexa ao Educandário Dom Duarte, uma escola que tem cerca de 380 alunos, cursando do $1^{\circ}$ ao $9^{\circ}$ ano do Ensino Fundamental. A professora aplicadora trabalha nesta UE desde 2011, e desde 2014 é regente em turmas de $5^{\circ}$ ano. A escola conta com seis salas de aula no turno da manhã e no turno da tarde. Possui um amplo espaço externo, pois está localizada na propriedade particular Liga das Senhoras Católicas. A escola localiza-se em prédio alugado pela prefeitura, e atende as comunidades do Jardim Esmeralda, Educandário, Parque São Jorge e arredores. Trata-se de um público de classe média baixa, tendo uma parcela de seus estudantes em situação de risco e maus-tratos, que são acompanhados por intermédio do Conselho Tutelar. O espaço externo à escola é um local muito bonito, amplo, com árvores e parquinho. Esta área pertence à Liga, mas os alunos e a comunidade do entorno podem usufruir. O espaço da Liga oferece assistência social e psicológica à comunidade, bem como cursos profissionalizantes aos jovens, atendendo uma boa parcela dos estudantes, que, no contraturno, participam de seus cursos.

Embora a clientela participe de situações difíceis e de risco, os estudantes apresentam-se interessados e muito participativos. E embora existam alunos com famílias desestruturadas, necessitando de apoio, a comunidade local é interessada, com famílias preocupadas com a aprendizagem de seus filhos.

Esta SD foi aplicada para 32 alunos de $5^{\circ}$ ano, com faixa etária entre 10 e 11 anos, todos da mesma classe, no período de abril a setembro de 2018.

\subsection{A organização da Sequência Didática}

A SD foi organizada em 13 aulas. Como explicado, devido a falta de disponibilidade de aplicação da autora-professora fora de seu horário de trabalho, procurou-se utilizar suas próprias aulas regulares para a aplicação da SD. Antes da aplicação, a autora-professora apresentou a proposta ao seu orientador de mestrado para a validação. A etapa seguinte foi realizada com as colegas professoras de turno na UE em que trabalha, que também contribuíram com sugestões. A última etapa foi a apresentação da SD à coordenação pedagógica, que sugeriu que para não comprometer apenas as aulas de Ciências com os conteúdos já previstos no 
planejamento, a professora utilizasse outras aulas da grade curricular, já que a proposta desta SD é interdisciplinar.

A SD foi elaborada da seguinte maneira:

- Título: Viagem pelo Sistema Solar

- Público Alvo

Esta SD foi elaborada para alunos do $5^{\circ}$ ano do Ensino Fundamental, mas também pode ser adaptada para séries a partir do $3^{\circ}$ ano.

\section{- Problematização}

A Astronomia é uma ciência que instiga a humanidade desde a Antiguidade. Os filósofos do passado questionavam-se sobre a origem do mundo, a nossa origem, onde de fato estamos, para onde iremos... O que são as estrelas, por que desaparecem com o clarear do dia? Nos dias atuais, apesar de um grande avanço tecnológico, muitas destas perguntas ainda passeiam pelo imaginário das pessoas... O objetivo desta proposta não é formar astrônomos, mas despertar nos estudantes o prazer pela busca do conhecimento e por meio desta Sequência Didática aproximálos mais ainda do fazer científico. A problematização implícita nesta sequência didática é fazer com que estes alunos criem outras perguntas complexas, e que reflitam sobre a grandeza do espaço, descobrindo que nosso pequeno planeta é precioso, pois abriga a única forma de vida que se conhece atualmente, e que para preservá-la é necessário conhecê-la, compreendê-la e defendê-la.

\section{- Objetivos Gerais e específicos}

Cada aula possui objetivos específicos. Entre estes objetivos o que se considera mais relevante é proporcionar aos estudantes participantes desta SD, situações em que possam ampliar o seu repertório de conhecimentos básicos de Astronomia, tais como: debater a origem do Universo, conhecer como alguns povos antigos explicavam a origem do mundo, entrevistar familiares e descobrir como 
acreditam que tenha ocorrido a origem do nosso planeta; adentrar especificidades dos planetas, sua formação e identificar nossa localização no planeta e na galáxia. Também faz parte dos objetivos a capacidade de reconhecer que o Sol é a estrela mais próxima do planeta Terra, e que a vida na Terra depende totalmente dele, refletir sobre o surgimento da Lua, questionar-se por que ela muda de aparência e por que é tão brilhante. Esta SD ainda procura abordar com os alunos as grandezas dos planetas e sua proporção de volume e distâncias e incentivar por meio das atividades a elaboração de perguntas e a busca de respostas a elas por meio de pesquisas. Ao final, desejamos trazer para o debate a importância da vida, o reconhecimento de que só conhecemos vida na Terra e refletir sobre o impacto das ações humanas para as gerações futuras e o comprometimento da vida, se não for pensado em forma de obter mais qualidade de vida e sustentabilidade. Apresenta-se na tabela 01 os objetivos específicos.

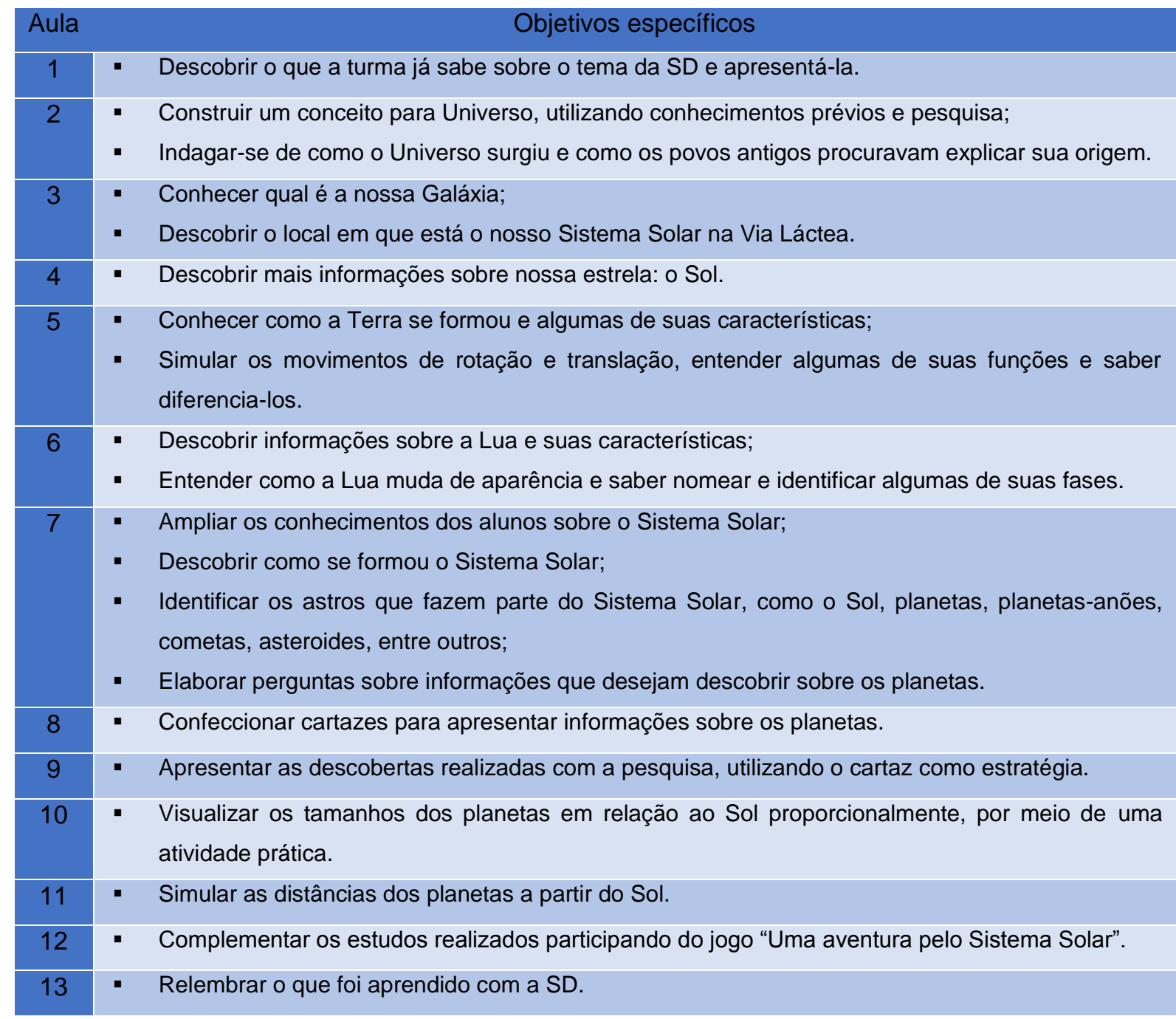




\section{- Conteúdos}

Os conteúdos estarão divididos nas treze aulas, apresentados na tabela 02:

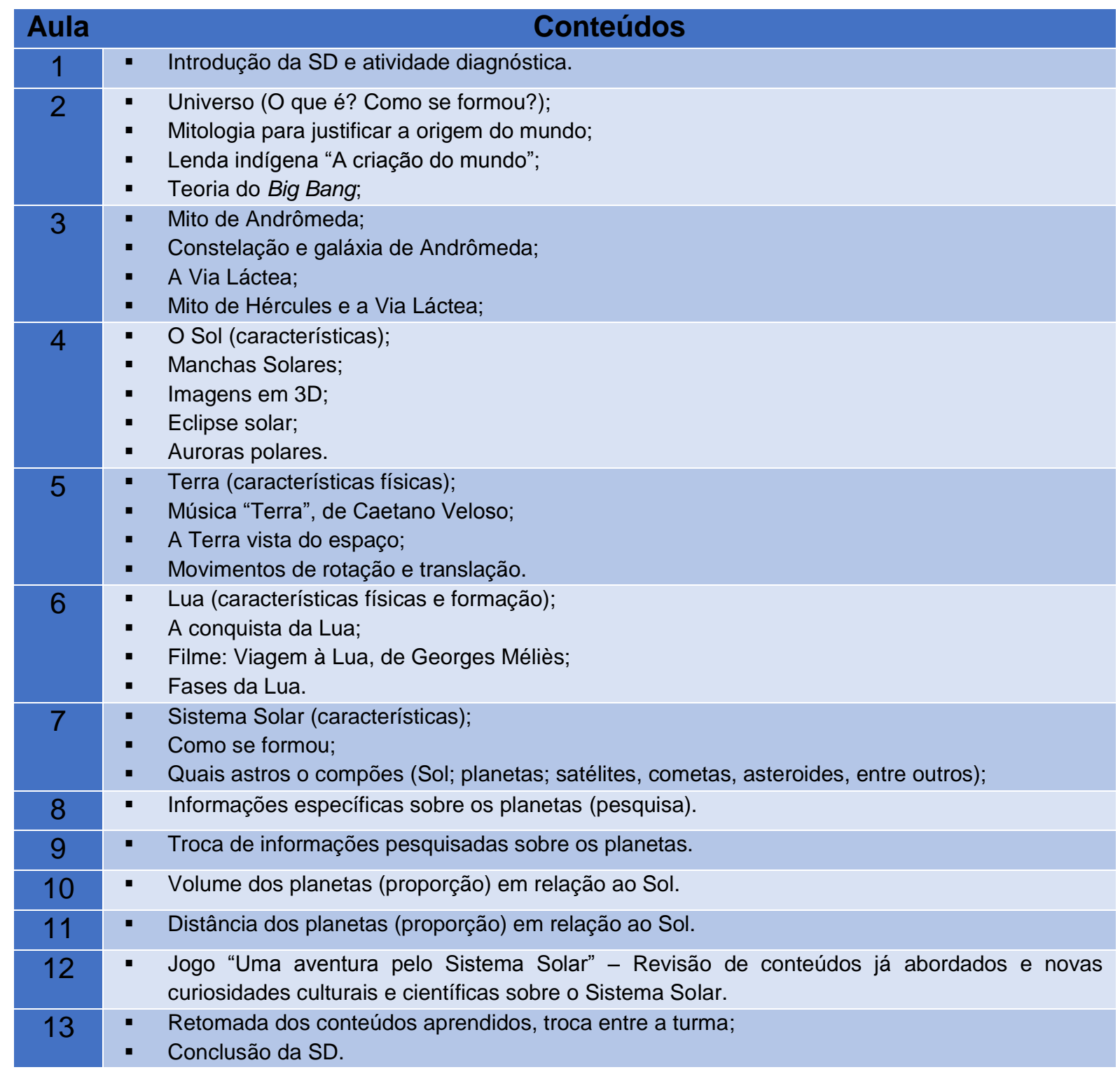

Tabela 02 - Apresentação dos conteúdos desenvolvidos na SD

\section{- Dinâmicas}

As aulas foram realizadas com uma diversidade de dinâmicas, nas quais foi fundamental a participação dos alunos. Por este motivo, organizamos a dinâmica das aulas com momentos para os estudantes participarem trazendo hipóteses, 
seus conhecimentos particulares, e de debates onde os estudantes puderam partilhar com os colegas o que já sabiam e aprender com o outro.

As aulas também contaram com vídeos, jogos de tabuleiro, uso de software, leitura de enciclopédias e livros de astronomia, bem como pesquisas, leituras de textos, experimentos e aulas expositivas, esmiuçados na tabela 03:

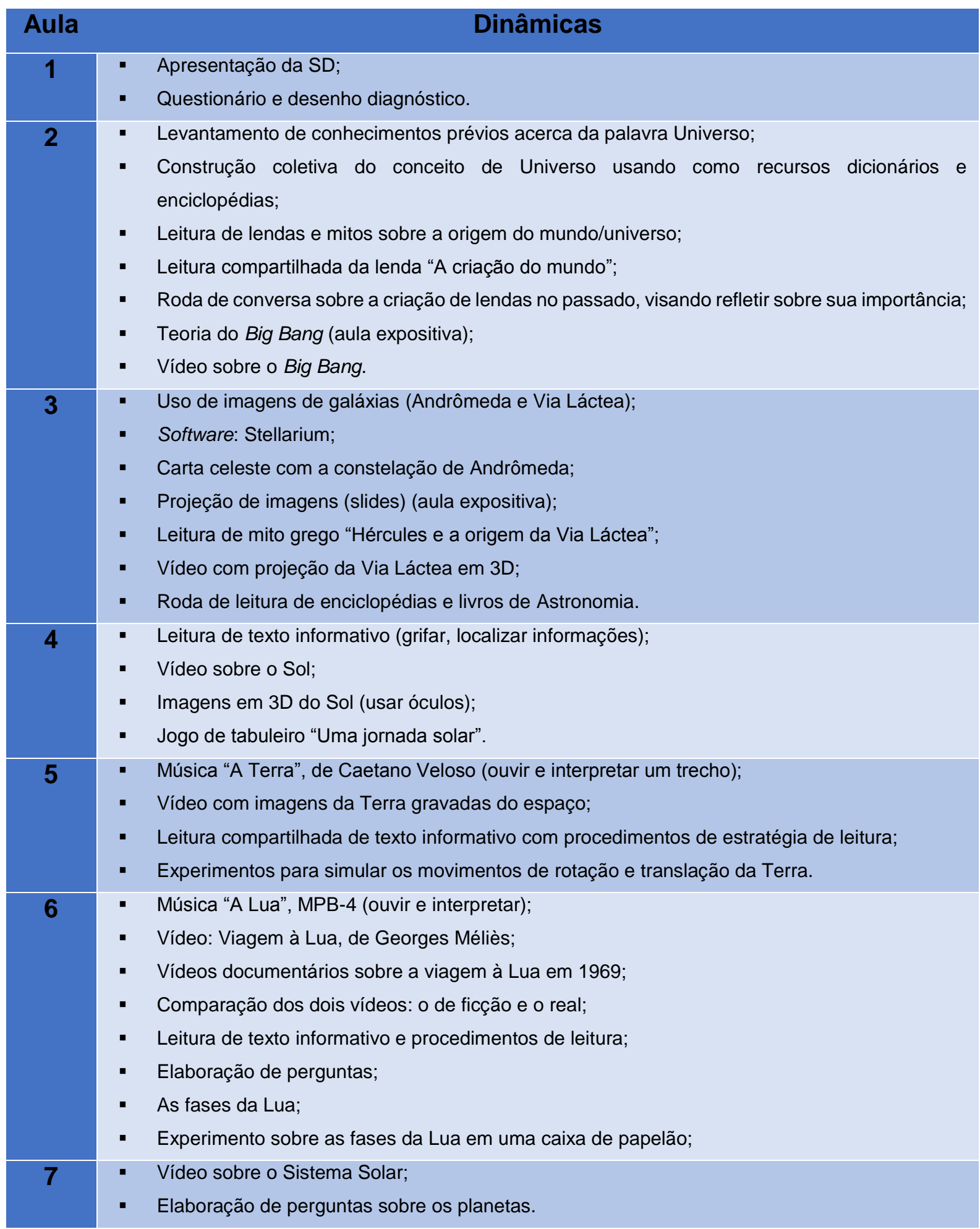




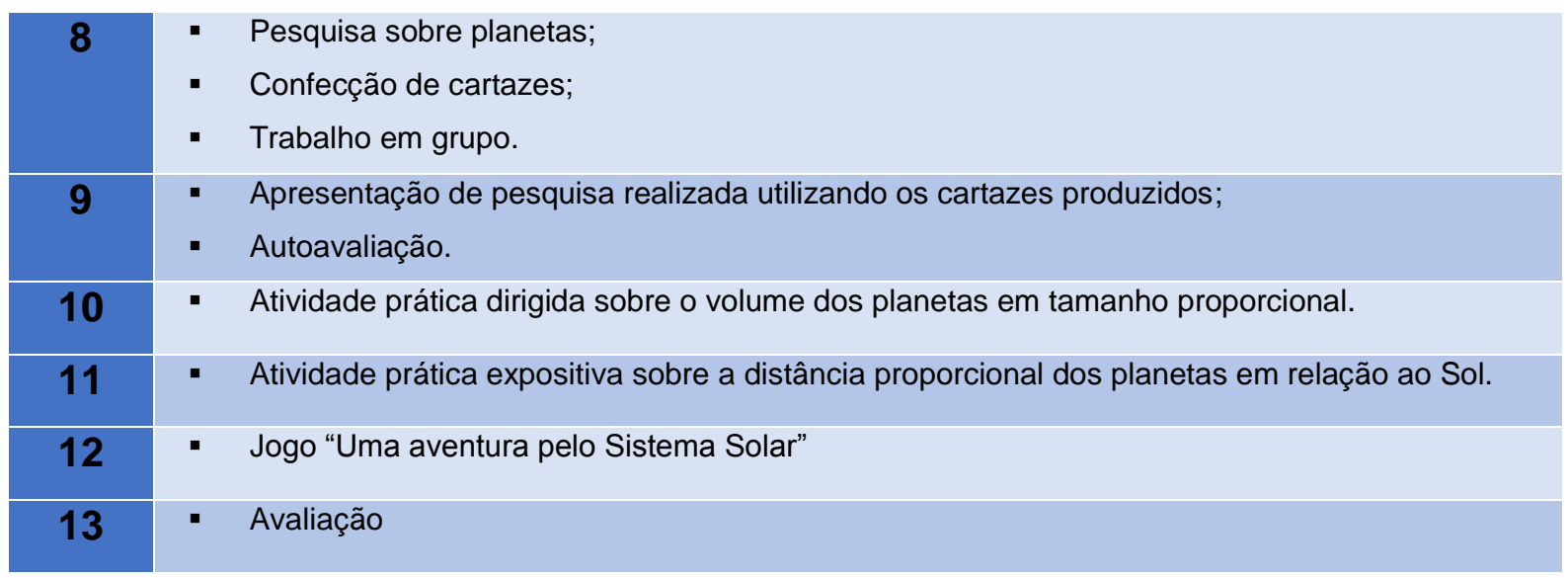

Tabela 03 - Apresentação das dinâmicas desenvolvidas na SD.

\section{- Materiais didáticos}

A escolha dos recursos didáticos foi fundamental para o sucesso das aulas, e para que tudo funcionasse perfeitamente, era necessária uma organização prévia dos materiais para as aulas. No item "Material de Apoio", criado para o professor (disponível no Apêndice) a cada aula, logo no início sugere-se todos os recursos didáticos que são utilizados para aquela aula específica, podendo estes ser adaptados ou substituídos.

No geral, o uso de um computador com projetor foi importante, bem como o recurso de áudio, para vídeos.

Também foi necessária a impressão de texto, confecção de jogos (impressão) e materiais para as aulas práticas, que serão explicados com mais ênfase durante a aplicação da SD. Ao todo serão materiais de baixo custo, que podem ser adaptados, mas essenciais para o trabalho.

Alguns materiais de uso contínuo são:

- Projetor;

- Computador com caixa de som;

- Abajur com uma lâmpada;

- Globo terrestre;

- Bolas de isopor com palitos para representar a Terra ou outro astro;

- Lanterna; 
- Avaliação

A avaliação durante a SD foi de forma contínua, ouvindo os alunos, permitindo que se expressassem, dizendo o que estavam aprendendo, com a oportunidade de sanar dúvidas e construir mais questionamentos. A cada aula proposta foi necessário estimular a participação dos alunos, bem como sua curiosidade, motivando os estudantes a pesquisar, questionar e debater.

Entretanto, no âmbito mais formal, os alunos foram convidados a preencher um questionário, e ao final da SD convidados a respondê-lo novamente. Além disso, os alunos ao início confeccionaram um desenho de seus conhecimentos prévios, e depois foram convidados a refazê-lo, adicionando ou excluindo imagens do desenho inicial. As rodas de conversa foram essenciais nesses momentos, tornando possível observar o quanto os estudantes estavam aprendendo, e em contraponto, o que a SD não deu conta de ensinar. 


\section{Capítulo 4 - A aplicação da Sequência Didática}

Apresentam-se a seguir todas as atividades realizadas durante a aplicação da SD. Observando-se o cronograma para a aplicação das atividades. Esta SD foi aplicada no período de abril a junho de 2018.

\section{Cronograma:}

\begin{tabular}{|c|c|c|c|c|}
\hline Aula & Datas & Descrição da atividade & Duração & Tarefas para casa \\
\hline 1 & $03 / 04$ & Levantamento de conhecimentos prévios & 2 aulas & $\begin{array}{l}\text { Pesquisar uma lenda ou mito } \\
\text { que explica a origem do mundo }\end{array}$ \\
\hline 2 & $10 / 04$ & Como surgiu o Universo? & 2 aulas & Ler do Mito de Andrômeda \\
\hline 3 & $17 / 04$ & $\begin{array}{l}\text { Nossa Galáxia: a Via Láctea. Onde está } \\
\text { nosso Sistema Solar? }\end{array}$ & 2 aulas & $\begin{array}{l}\text { Procurar informações sobre a } \\
\text { estrela mais próxima de nós: o } \\
\text { Sol }\end{array}$ \\
\hline 4 & $24 / 04$ & A estrela mais próxima de nós: o Sol & 2 aulas & $\begin{array}{l}\text { Pesquisar o que são auroras } \\
\text { boreais e austrais. }\end{array}$ \\
\hline 5 & $03 / 05$ & A Terra & 2 aulas & $\begin{array}{l}\text { Levantar conhecimentos prévios } \\
\text { sobre a Lua, por meio da análise } \\
\text { da letra de uma música. }\end{array}$ \\
\hline 6 & 08/05 & A Lua (1 ${ }^{a}$ etapa) & 2 aulas & $\begin{array}{l}\text { Pesquisar informações sobre a } \\
\text { Lua que não descobrimos na } \\
\text { aula de hoje }\end{array}$ \\
\hline 6 & $10 / 05$ & A Lua (2 $2^{\mathrm{a}}$ etapa) & 2 aulas & Não há \\
\hline 7 & $15 / 05$ & O Sistema Solar & 2 aulas & $\begin{array}{l}\text { Pesquisar informações sobre um } \\
\text { planeta do Sistema Solar }\end{array}$ \\
\hline 8 & $22 / 05$ & Os planetas - trabalho em grupo & 2 aulas & $\begin{array}{l}\text { Ensaiar para a apresentação da } \\
\text { pesquisa. }\end{array}$ \\
\hline 9 & $29 / 05$ & Os planetas - trabalho em grupo & 2 aulas & $\begin{array}{l}\text { Trazer uma imagem que } \\
\text { representam o Sistema Solar. }\end{array}$ \\
\hline 10 & $05 / 06$ & Qual é o tamanho dos planetas? & 2 aulas & $\begin{array}{l}\text { Desenhar o que você aprendeu } \\
\text { na aula de hoje }\end{array}$ \\
\hline 11 & $12 / 06$ & Qual é a distância dos planetas? & 2 aulas & $\begin{array}{l}\text { Escrever como você explicaria } \\
\text { os tamanhos e distâncias dos } \\
\text { planetas do Sistema Solar. }\end{array}$ \\
\hline 12 & $19 / 06$ & Um jogo sobre o Sistema Solar & 2 aulas & $\begin{array}{l}\text { Escrever o que você aprendeu } \\
\text { com o jogo }\end{array}$ \\
\hline 13 & $26 / 06$ & Avaliação: O que eu aprendi? & 2 aulas & Não há \\
\hline
\end{tabular}

Tabela 04 - Cronograma de atividades

\subsection{Aula 1 - Levantamento de conhecimentos prévios}

Nesta primeira aula apresentou-se aos alunos a proposta da Sequência Didática, os objetivos e o percurso do estudo que seria realizado nos próximos encontros. Os alunos puderam se expressar, contando sua expectativa para com a atividade, mencionando inclusive aspectos que já conheciam sobre o tema, pois, segundo Pavão (2017), devemos iniciar nossas aulas identificando e valorizando o conhecimento que o aluno já detém sobre o que se pretende ensinar. 
Realizou-se a leitura do cronograma de aulas da SD. Neste momento os alunos começaram a mostrar grande entusiasmo, levantando a mão para fazer perguntas. Um exemplo deste momento foi durante a apresentação da aula 3, sobre a Via Láctea, que o aluno 1 disse: "Eu sei! Na Via Láctea ficam girando todos os planetas". Não foi feita nenhuma correção ao comentário dela, pois naquele momento o importante era que eles se sentissem animados e curiosos, e por isto, a professora aplicadora e autora da SD apenas respondeu: "Olha que bacana, pessoal! Vamos descobrir nas próximas aulas muito mais sobre os planetas!".

Seguiu-se apresentando o cronograma, e os alunos logo já faziam um novo questionamento sobre o Sol e a Lua. O aluno 7 perguntou: "O Sol é feito de fogo? E a Lua é feita do quê?". Vários alunos por conta do entusiasmo procuraram responder às perguntas do colega, mas procurou-se apenas tentar acalmá-los, combinando que naquele momento estava-se apenas descobrindo o assunto das aulas que iriam estudar, e que nas próximas semanas eles poderiam falar sobre estas perguntas, e aí sim, todos poderiam falar o que sabiam, e o melhor, aprender coisas novas.

Ao final do cronograma, os alunos foram convidados a responderem um questionário. Foi também explicado aos estudantes que as respostas eram importantes para a professora-aplicadora poder descobrir o que eles já sabiam sobre o assunto, e assim organizar as próximas aulas da melhor forma possível. Também se explicou que após o questionário eles fariam um desenho.

Entregou-se aos alunos o questionário com quatro perguntas dissertativas e quatro perguntas com alternativas, como exposto na tabela 05:

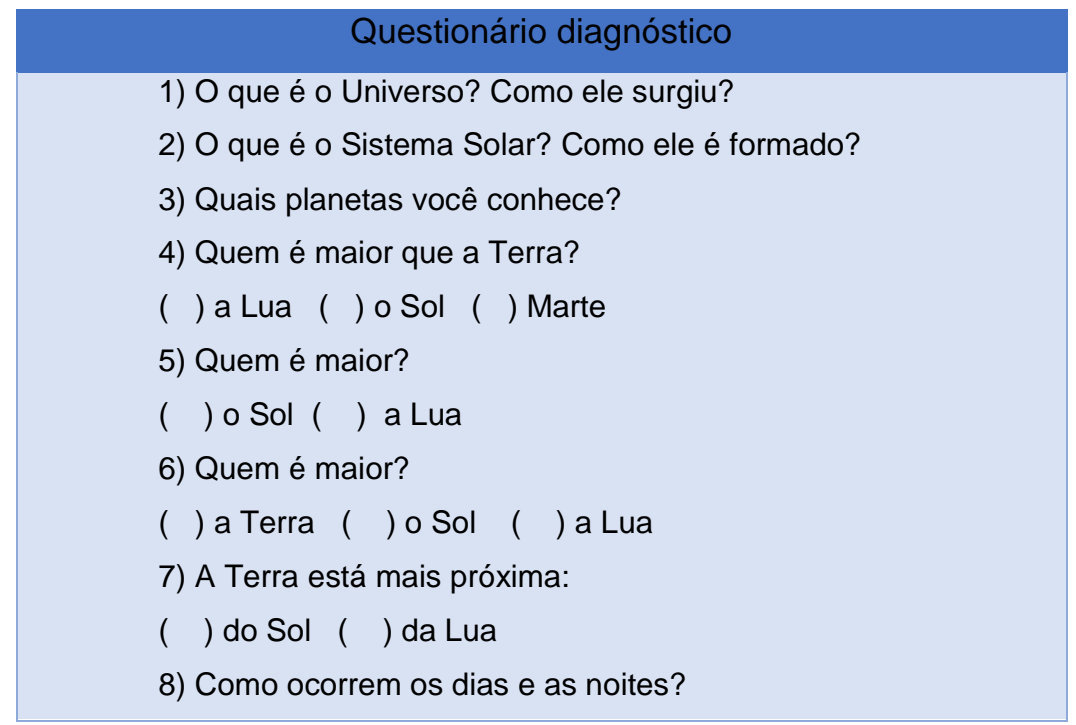

Tabela 05 - Perguntas do questionário diagnóstico 
Os alunos estavam preocupados em como responder o questionário. Mostravam-se ansiosos em "acertar" as perguntas, então a professora procurou tranquilizá-los, explicando que aquele questionário não era avaliativo, e sim, apenas o ponto de partida para o início das próximas atividades. Ela ainda explicou que o mais importante era conhecer sobre o que cada um já sabia sobre aqueles assuntos. E se não sabiam, não teria problema, porque estudariam sobre todos aqueles itens nas próximas aulas.

Após a conclusão do questionário, a professora orientou os alunos para a segunda etapa desta atividade, que era a confecção de alguns desenhos. Ela entregou uma folha de sulfite para cada aluno e orientou que eles desenhassem: A Terra, o Sol e a Lua; o lugar onde estão no planeta e outros corpos celestes que conheciam.

Os estudantes se mostraram interessados e mais confiantes nesta segunda etapa da aula. Entretanto, fizeram muitas perguntas, desenhavam planetas, mas vinham perguntar qual era o nome deles, mostrando alguma de suas características. Saturno apareceu bastante, mas notou-se que poucas crianças sabiam nomeá-lo. Como lição de casa, a professora solicitou que pesquisassem na internet, em livros ou com a família, uma lenda ou mito que explicasse a origem do mundo, que escrevessem em uma folha e trouxessem para a próxima aula.

\subsection{Aula 2 - Como surgiu o Universo?}

Os alunos apresentavam grande entusiasmo para a aula. A professora por sua vez instigava a turma a levantar hipóteses do que é o Universo. Ela anotou no quadro as ideias apresentadas:

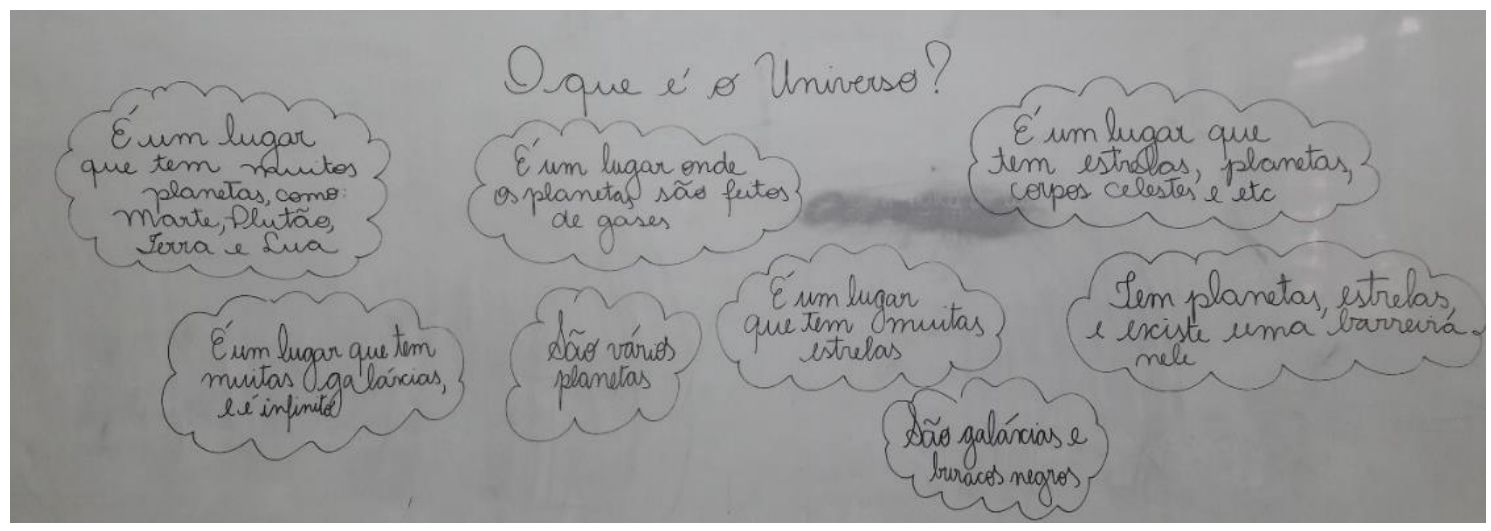

Figura 2 - Hipóteses levantadas pelos alunos sobre o que é o Universo 
Em seguida, procurou-se construir com as ideias sugeridas e com o auxílio de alguns dicionários e enciclopédias um parágrafo definindo: Universo.

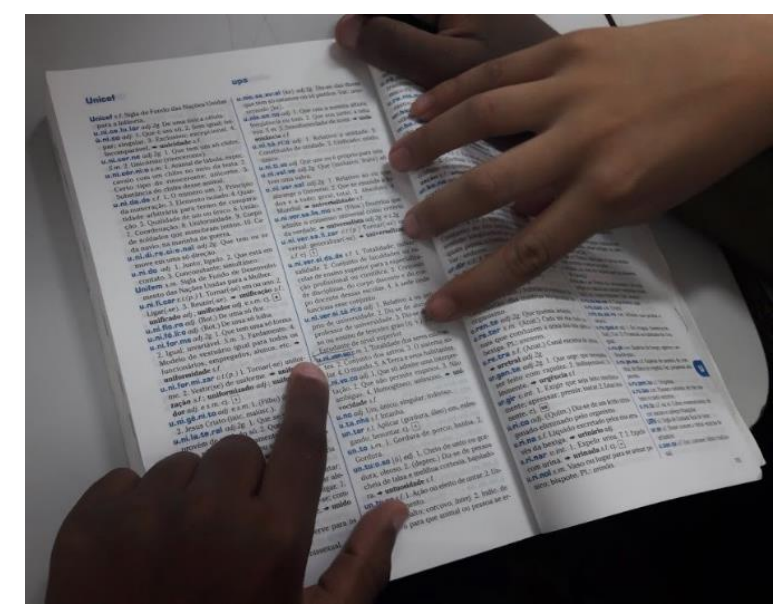

Figura 3 - Estudante procurando no dicionário o significado de Universo

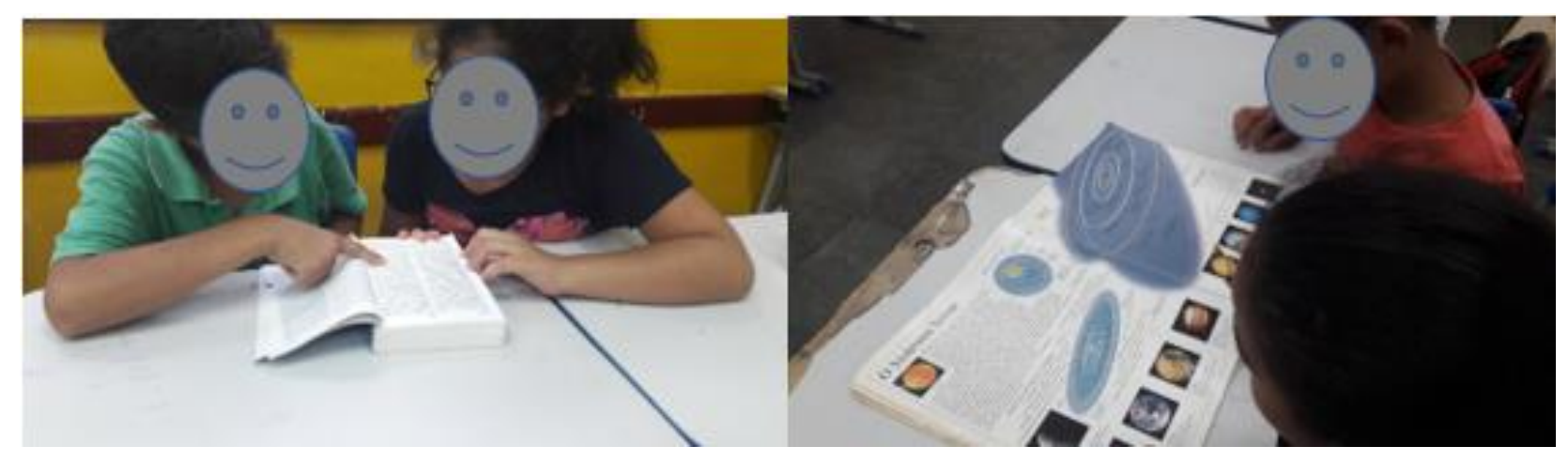

Figura 4 - Estudantes procurando no dicionário e em enciclopédia o significado de Universo

Após a pesquisa de duplas e trios, a professora conseguiu reunir algumas definições:

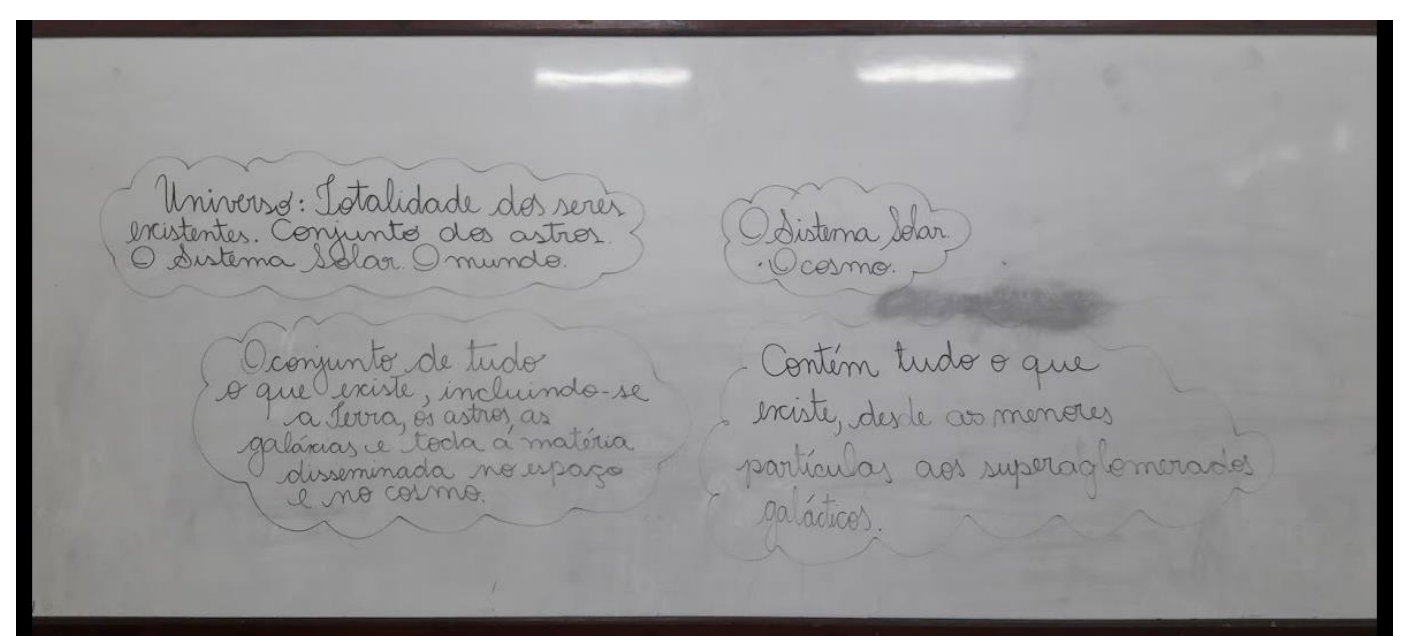

Figura 5 - Conceitos encontrados pelos estudantes 
E, em conjunto, a turma elaborou um parágrafo para conceituar Universo:

"É o conjunto de todos os astros que existem. É o espaço que se ocupam as estrelas, planetas, galáxias e toda a matéria".

Concluído este primeiro momento, a professora fez a seguinte pergunta aos alunos: Como surgiu o Universo? Como vocês acreditam que o Universo surgiu?

Procurou-se estimular novamente a participação dos estudantes, sugerindo que contassem o que descobriram na lição de casa, sobre as lendas que tinham pesquisado.

Entretanto, a princípio os alunos permaneceram tímidos. Procurou-se começar a perguntar se alguém podia compartilhar o que tinha descoberto na pesquisa, se existia alguma história sobre a origem do mundo. O silêncio entre os alunos ainda permaneceu, até que foi perguntado: "Bom, então mesmo que alguns de vocês não conseguiram pesquisar, gostaríamos de saber se vocês já falaram sobre isso com a família? Vocês conhecem alguma história sobre a origem do mundo?". O aluno 4 resolveu participar e começou a falar: "Sim, na minha igreja contam que foi Deus que fez o mundo, em sete dias, acho que foi sete..." O aluno conta mais detalhes, tentando explicar que em cada dia foi feito uma coisa, até o homem e a mulher serem feitos e o mundo começar a existir. Outros estudantes concordaram com o colega e disseram que já tinham ouvido aquela história também.

Essa participação inicial permitiu que outros alunos começassem a compartilhar o que tinham pesquisado. A aluna 8 levantou a mão e disse: "Eu achei na internet que a origem do mundo veio do Big Bang. Aqui tá escrito que (lendo no papel) a teoria mais aceita sobre a origem do Universo é de que o Universo teria nascido a partir de uma concentração de energia extremamente quente... nesse momento ocorreu uma explosão e veio o Big Bang". Ao final se sua leitura, outra colega levantou a mão dizendo que havia descoberto isto também em sua pesquisa. E mais três alunos concordam com elas, e o aluno 9 completou dizendo que "depois do Big Bang surgiram as primeiras galáxias".

Passando por este momento inicial, os estudantes começaram a ter mais segurança e o aluno 11 pediu para ler sua história. Tratava-se de um mito de origem africana. Por fim, o aluno 7 leu também seu mito, baseado nas histórias dos 
aborígenes da Austrália. Concluiu-se esta primeira conversa e seguiu-se para o segundo momento da aula.

Prosseguiu-se dizendo aos alunos que muitas civilizações do passado procuravam compreender como o mundo surgiu, e isto foi possível identificar durante a atividade anterior, já que os próprios estudantes encontraram diferentes mitos e lendas. Dessa forma, foi proposta a leitura compartilhada de uma lenda indígena, pertencente à tribo do povo Araweté, que viveu às margens do rio Xingu. Esta lenda também explicava a origem do mundo. Devido ao texto ter uma linguagem um pouco diferenciada, foi necessário a realização da leitura pela professora, e algumas pausas para que fosse possível a interação dos alunos e sua compreensão do que estava sendo lido. A lenda proposta segue:

\section{A criação do mundo \\ Lenda do povo Araweté, habitante da região do rio Xingu}

Houve um tempo em que o mundo era sem morte e sem trabalho. Existiam na terra os índios e os Mais, uma tribo de imponentes homensdeuses. Não havia as roças e nem o fogo; todos colhiam o mel e as frutas. Não se conheciam as doenças; a velhice e a morte não existiam. A floresta era amiga e os animais, dóceis. Durante as noites, os índios e os Mais fumavam grandes charutos, cantavam e dançavam; não se tinha inventado a mentira e a maldade; todos eram amigos, casavam-se entre si e viviam em harmonia.

O chefe Mai, Ananãmi, havia se casado com uma índia. Moravam felizes em uma aldeia ao lado de árvores cheias de frutos e cipós floridos.

Um dia, sem motivo nenhum, a mulher de Anañami discutiu com ele. Levantou a voz e, aos gritos, o insultou. O mundo todo parou surpreso. Aquilo jamais havia sido visto.

O grande chefe Mai percebeu então que o paraíso estava morto. Chamou seu sobrinho Hehede, pegou seu chocalho de pajé e começou a cantar e a fumar. Foram rodeados por toda a aldeia, que se espantou quando o solo de pedra, onde estavam os dois, começou a subir sem parar até desaparecer nas alturas. Foi assim que surgiu o céu.

Estava feita a confusão na Terra.

Muitos Mais subiram com Anañami. O céu povoou-se de guerreiros divinos, que levaram o paraíso com eles. As melhores plantas, os melhores animais foram viver nas alturas. Alguns Mais subiram mais alto, criando o céu vermelho que era o céu do céu.

Abandonada e perdendo o seu suporte de pedras, a terra começou a se dissolver em água; jacarés e piranhas esfomeados saíram dos rios e devoraram os índios. Uma tribo Mai, que tinha ficado para trás, afundou n'água e entrou terra adentro. Passou a viver em grandes ilhas nos rios subterrâneos.

Os índios foram desaparecendo um a um. Os que não foram devorados acabaram por afogar-se. Só três pessoas escaparam. Dois homens e uma mulher, mais rápidos que os demais, subiram em um pé de bacaba e de lá assistiram ao desastre. Viriam a ser, depois, os pais de todos os índios. 
Quando as águas desceram, a terra estava diferente. Aos poucos, povoou-se de animais ferozes; as árvores já não ofereciam tantas frutas; os sobreviventes tiveram que passar a pescar, caçar e plantar para viver. Anañami teve pena deles e mandou um pássaro vermelho para lhes ensinar a fazer fogo, plantar os roçados, construir canoas e tratar a grande quantidade de doenças que surgiram e a enterrar os mortos.

A vida no céu era muito diferente da que se levava na terra. Lá as sementes brotavam sozinhas, as frutas e o mel estavam ao alcance da mão. Anañami levou o segredo da juventude e não havia nada a fazer além de cantar, dançar e beber cauim. Os deuses eram bonitos e altos, o corpo pintado com tinta de jenipapo de um negro brilhante, e usavam maravilhosos cocares de penas de araras. Tudo era feito de pedra que não estraga com o tempo. E, se o tempo não se fazia sentir ao passar, então a vida deles era sempre presente e não existia futuro.

$\mathrm{Na}$ terra existia o tempo, o envelhecer, o esperar o dia de amanhã. $\mathrm{O}$ futuro. Na terra existia a esperança. Isso foi um presente de Anañami aos homens.

VAL, Vera do. A criação do mundo: e outras lendas da Amazônia. ilustrações de Geraldo Valério. - São Paulo: WMF Martins Fontes, 2008. P. 13 a 15.

A professora teve que interromper a leitura em alguns momentos, para certificar-se de que os alunos estavam compreendendo a história. Ela procurou questioná-los no primeiro parágrafo:

- Será que era bom viver nesse mundo? Por quê?

- Quem eram os Mais? O que os diferenciava dos outros índios?

Ela deu continuidade na história e mais ao final perguntou:

- Todos os índios que viviam na terra morreram?

- Qual era a diferença da vida na terra e no céu?

Ao finalizar a leitura da lenda, a professora ainda questionou os alunos:

- Será que a origem do mundo é como os Areweté contam?

Os alunos se manifestaram contrários a história para explicar a origem do mundo, mas também disseram que já tinham ouvido outras lendas, e que elas são histórias inventadas.

Prosseguindo a aula e aproveitando que os alunos já tinham manifestado sua opinião a professora concordou com eles dizendo que "o ser humano sempre olhou para o céu se perguntando o que são as estrelas e como tudo isso se formou, e que 
sim, lendas foram criadas para explicar algo que de fato ninguém sabe como aconteceu".

Entretanto, continuou explicando "há uma teoria mais aceita atualmente no meio científico que explica a origem do Universo: a teoria do Big Bang”. Assim, chegou-se a última etapa desta aula.

Explicou-se a turma que os cientistas acreditam que há aproximadamente 14 bilhões de anos, tudo o que existe hoje no Universo estava concentrado em um único ponto. Em determinado momento ocorreu a expansão dessa matéria que ficou conhecida como o Big Bang. Ao serem lançadas no espaço, essa energia e matéria, foram sofrendo transformações e dando origem a tudo o que conhecemos hoje. Os cientistas afirmam isso porque ao longo dos anos ao observar as estrelas notaram que elas estão se afastando umas das outras. Para complementar a aula a professora exibiu um vídeo sobre o Big Bang da TV Escola - ABC da Astronomia, disponível no link: https://tvescola.org.br/tve/video/abc-da-astronomia-big-bang

A conclusão da aula foi de que apesar de existir uma teoria para explicar a origem do Universo, ainda não temos uma explicação definitiva para isso.

A lição de casa proposta ao final desta aula foi a leitura e interpretação de uma nova lenda - o mito de Andrômeda.

\subsection{Aula 3 - Nossa Galáxia: a Via Láctea. Onde está nosso Sistema Solar?}

A aula três iniciou-se com a retomada da lição enviada para os alunos fazerem em casa. Tratava-se da leitura do mito de Andrômeda e os alunos deveriam responder a algumas perguntas. Na própria atividade já se fazia uma menção a constelação de Andrômeda, e sugeria que os alunos demonstrassem sua percepção em "visualizar" a figura de Andrômeda na constelação.

A professora iniciou a leitura com a turma do mito de Andrômeda e foi perguntando aos estudantes suas respostas nas questões propostas. Ao final da atividade se apresentava uma imagem do asterismo da constelação de Andrômeda. Os alunos foram questionados se conseguiam enxergar uma mulher na imagem. As respostas foram diversas. Alguns alunos afirmaram que sim, e outros riam, dizendo que não conseguiam perceber. Por meio da apresentação já elaborada para esta finalidade. Eles puderam "visualizar" o desenho. Na atividade, sugeria-se que os 
alunos por meio dos pontos que são as estrelas ligassem as linhas e fizessem novos desenhos. Esta atividade permitiu discutir com a turma que as representações das constelações variam de povos para povos, pois a percepção de cada indivíduo é singular. Por fim, apresentou-se aos alunos a imagem da galáxia de Andrômeda. No primeiro momento, foi proporcionado aos alunos um momento para apreciar a imagem, e depois a professora contou aos alunos que esta era a galáxia mais próxima da nossa Galáxia, a Via Láctea.

Em seguida, perguntou-se aos alunos:

O que é uma galáxia?

Os alunos se manifestaram, já com mais facilidade, mas não conseguiram construir um conceito próximo à galáxia. Ainda confundiam bastante o conceito de Universo, com galáxia e estrelas. O aluno 24 disse que galáxia era a casa de muitas estrelas, e o Sol estava nessa casa. A professora aproveitou a fala deste aluno, para dizer que além do conjunto de estrelas, também há outros astros que compõem uma galáxia. Passou-se então à definição de galáxia aos alunos e eles copiaram em seus cadernos.

Seguiu-se com a segunda etapa da aula, a apresentação da Via Láctea.

A princípio se projetou uma foto em que aparece uma parte da Via Láctea no céu noturno.

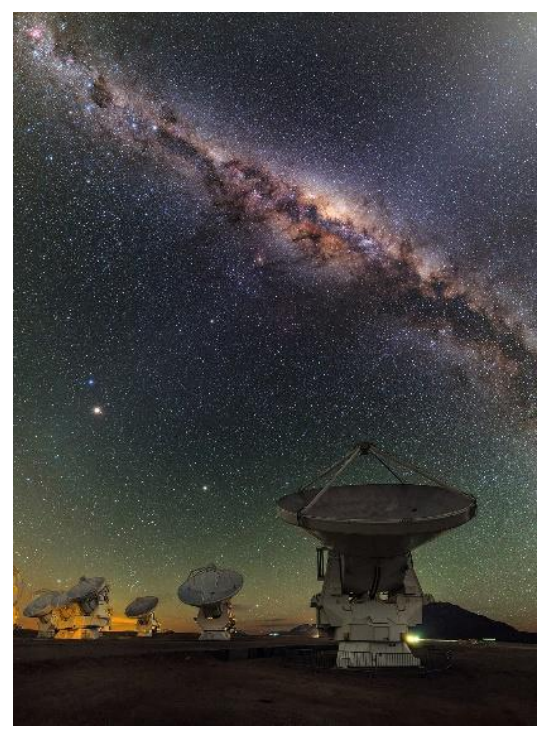

Figura 6 - Fotografia para mostrar parte da Via Láctea.

https://commons.wikimedia.org/wiki/File:ALMA and the centre of the Milky Way.jpg 
Contou-se aos alunos que os gregos ao observarem essa linha branca no céu noturno, criaram uma lenda para explicar isso. Foi o mito de Hércules ao ser amamentado por Hera, que simbolizou o derramamento de leite.

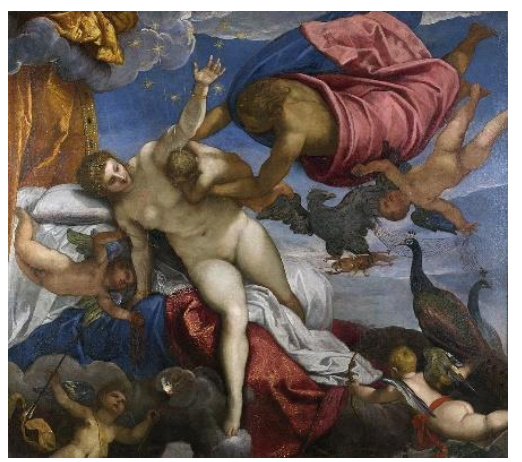

Figura 7 - Quadro de Jacopo Tintoretto - The Origin of the Milky Way (A origem da Via Láctea) https://pt.wikipedia.org/wiki/Ficheiro:Jacopo Tintoretto - The Origin of the Milky Way - Google Art Project.jpg

Prosseguindo a aula, a professora mostrou aos alunos uma figura da Via Láctea, e explicou que a imagem era uma simulação, ou seja, uma representação, pois não é possível fotografar completamente a Via Láctea. Os alunos logo quiseram saber por quê. Então se explicou que até hoje não se conseguiu fotografar a Via Láctea inteira, pois ainda é impossível "sair" dela, devido ao seu gigantesco tamanho, mas já se sabe que a Via Láctea é uma galáxia no formato espiral, redonda e achatada com um grande disco côncavo.

Para explicar melhor a professora exibiu um curto vídeo para os alunos terem uma ideia melhor do formato da galáxia em 3D. https://www.youtube.com/watch?time continue=4\&v=dtfLbbAZ6FU

A professora então perguntou:

Onde está o nosso Sol, nessa Galáxia com bilhões de estrelas?

Os alunos começaram a procurar na imagem projetada o Sol. O aluno 4 falou "é impossível", o aluno 12 respondeu, com muita certeza "é claro que ele está aqui" (apontando para o centro da Galáxia). Outras crianças concordaram com o aluno 12. O aluno 4 ainda estava desconfiado da certeza dos outros colegas, porque ele não estava vendo os planetas e nem a Terra, mas por fim concordou com os demais que o Sol estava no centro da Galáxia.

A professora projetou outra imagem mostrando a localização da nossa estrela, o Sol, na Via Láctea. Os alunos realizaram diversos comentários impressionados com o tamanho tão pequeno, já que o Sol é uma estrela tão poderosa e grande, no seu entender. 
Para finalizar a aula foram disponibilizados aos alunos enciclopédias, dicionários ilustrados e revistas com artigos sobre o espaço para os alunos manusearem. Os alunos foram orientados e lerem as informações presentes nos sumários dos livros, para conseguirem encontrar as páginas dos assuntos que mais Ihe interessavam. Este foi um momento muito rico, pois os alunos se envolveram e ficaram entusiasmados com as belas fotografias presentes nos livros, desejaram copiar informações, fazer desenhos de observação e ler com colegas as informações que achavam mais curiosas.

Como lição de casa os alunos levaram uma pesquisa para levantar informações sobre a composição, tamanho, temperatura e outras curiosidades a respeito do Sol.

\subsection{Aula 4 - A estrela mais próxima de nós: o Sol}

Iniciou-se a aula com o levantamento das respostas encontradas pelos alunos durante a pesquisa sobre o Sol. A professora foi lendo em voz alta pergunta por pergunta, e os alunos foram fazendo comentários e citando as respostas encontradas. Ela procurou anotar algumas informações no quadro para comparar com as informações que encontrariam no decorrer da aula.

Passado este momento inicial, a professora entregou aos alunos o texto "Nossa estrela, o Sol". A leitura desse texto seria realizada de forma investigativa; sendo assim, a professora realizaria a leitura compartilhada com os alunos, e faria perguntas estratégicas durante alguns momentos.

Geralmente esse tipo de texto, o de divulgação científica, traz nomenclaturas não muito bem conhecidas pelos estudantes, e para isso é necessário "ensinar" os alunos a lerem e compreenderem o que estão lendo. As estratégias de grifar, ler o glossário, buscar palavras desconhecidas no dicionário e procurar informações não conhecidas em outros textos ou vídeos facilita a compreensão, e por este motivo, é uma situação interessante a se propor aos alunos. O intuito é "ensinar" o leitor conhecimentos adequados para elaborar uma boa interpretação de texto (SOLÉ, 1998, p.71)

Para que a leitura ocorresse, a professora utilizou algumas estratégias, como descritas a seguir: 


\section{- Antes da leitura:}

A professora explicou aos estudantes que eles iriam ler um texto sobre o Sol. Também orientou os alunos que a leitura seria um pouco diferenciada da leitura que costumam fazer, pois eles iriam realizar algumas pausas sobre o que estavam lendo, para compreenderem tudo melhor. Ela disse ainda que a princípio faria algumas perguntas antes de começar a ler.

Dando início a atividade ela disse aos alunos:

"Pessoal, sem ler o texto inteiro, eu gostaria de saber se vocês conseguem me responder ou encontrar onde podem estar algumas destas informações" e fez a seguinte pergunta:

- O que são manchas solares?

O aluno 7 rapidamente levantou a mão citando que no subtítulo "O Sol tem manchas e coroa?" deveria ter essa informação. O aluno 25 concordou com o colega, dizendo que era verdade, porque tinha um espaço grifado escrito "manchas solares".

A professora concordou com os alunos e fez uma nova pergunta:

- O que é um eclipse?

O aluno 15 levantou a mão e disse que devia estar no final do texto no box "Você sabia? - Eclipses solares". A turma concordou, pois já tinham compreendido a estratégia de localizar os subtítulos. A professora seguiu então com uma nova pergunta:

- O que é diâmetro?

Os alunos permaneceram em silêncio durante algum tempo, procurando novamente nos subtítulos a informação, mas não encontraram, até que o aluno 32 falou que estava escrito do lado, numa pequena tabela. A professora fez outra pergunta:

- Qual é a temperatura do Sol?

Os alunos começaram a procurar, agora não se atentando apenas aos subtítulos. Até que descobriram que esta informação estava em uma tabela.

A professora finalizou esta primeira etapa e iniciou a leitura compartilhada do texto. Optou-se por essa metodologia, devido ao texto de iniciação científica apresentar termos que poderiam dificultar a leitura dos alunos e atrapalhar a interpretação adequada das informações. 
É importante ressaltar, que nesse momento, optou-se também pela leitura única feita pela professora, pois se a leitura fosse feita por parágrafos, com um aluno lendo de cada vez, por exemplo, poderia se perder o sentido do texto, dificultando a compreensão.

\section{- Durante a leitura:}

A professora iniciou a leitura do texto, pedindo aos alunos para irem acompanhando a leitura. Ao terminar o primeiro parágrafo ela perguntou "Qual é a informação mais importante nesse parágrafo?". Os alunos participaram citando alguns trechos, então a professora os orientou a grifar com um lápis colorido ou marca texto estes trechos.

\section{- Após a leitura:}

Após a leitura, a professora permitiu que os alunos fizessem perguntas e para concluir o estudo assistiram a um vídeo sobre 0 Sol: https://www.youtube.com/watch?v=ZEiJLhtkfGM

Ao final desta etapa, a professora entregou óculos 3D para cada aluno e projetou imagens e vídeos do Sol. Neste link www.iag.usp.br/ eder/CarolinaSilveiraLeite, encontra-se todo o material organizado para esta aula, na pasta: Sol.

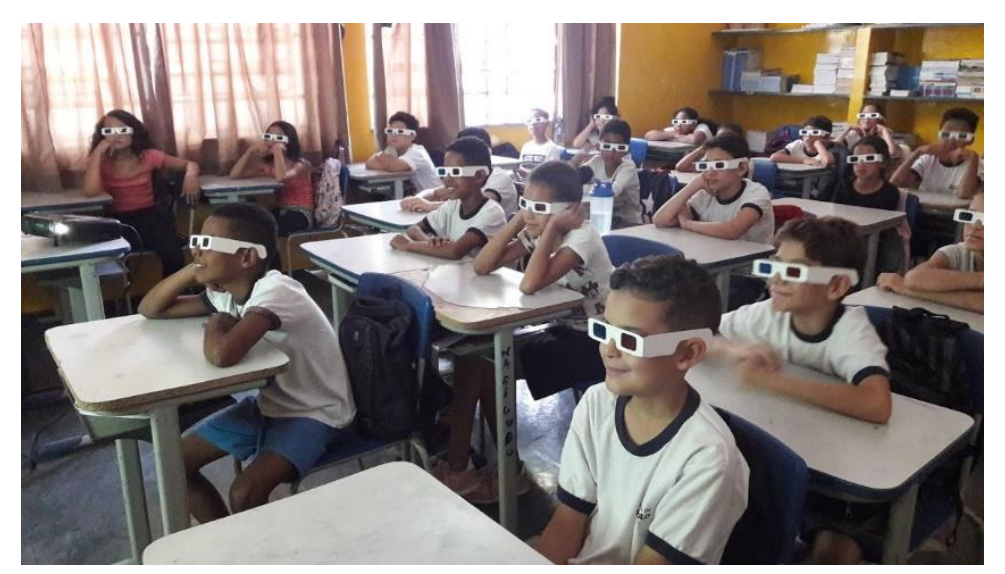

Figura 8 - Estudantes observando imagens e curtos vídeos do Sol em 3D 
Ao final da aula, a professora propôs um jogo de tabuleiro, elaborado por ela para esta finalidade, para a turma. Assim, os assuntos abordados na aula poderiam ser revistos e os alunos poderiam aprender novas informações.

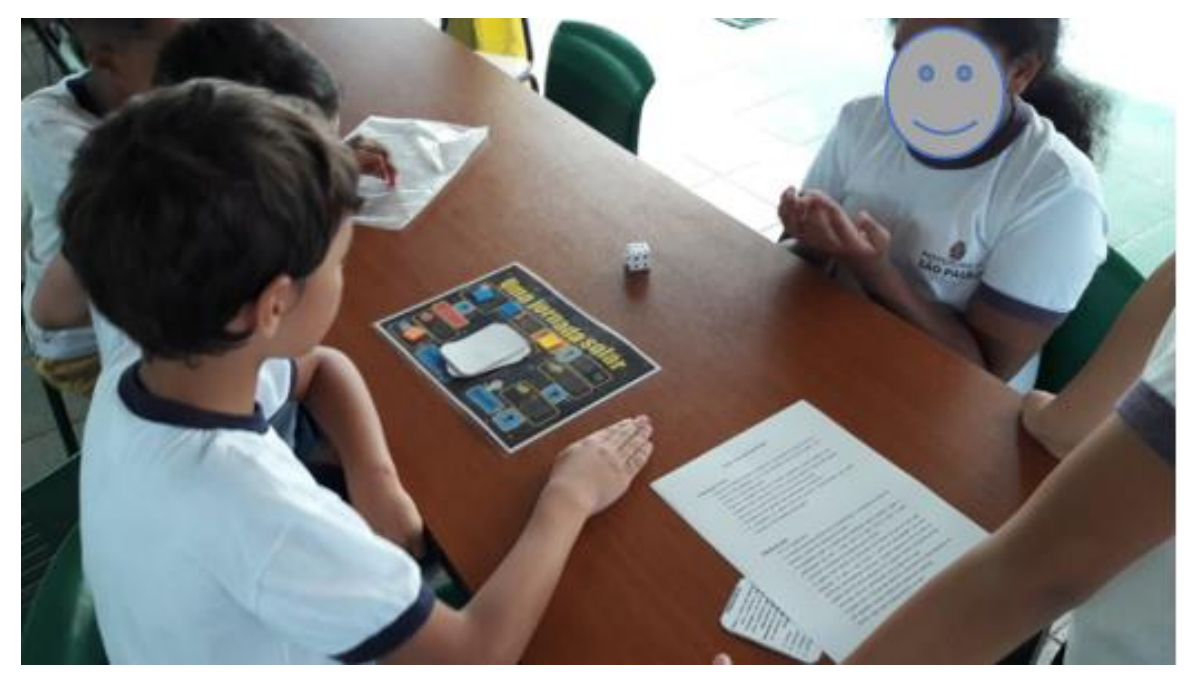

Figura 9 - Estudantes jogando o jogo "Uma jornada solar"

Os estudantes demonstraram interesse em participar do jogo, mas reclamaram de que ele acabava muito rápido.

Como lição de casa os alunos levaram uma pesquisa sobre a formação das auroras polares.

\title{
4.5 Aula 5 - A Terra
}

A aula se iniciou com a professora propondo aos alunos ouvirem o início da música "Terra" com compositor Caetano Veloso, apenas do trecho a seguir:

\author{
"Quando eu me encontrava preso \\ $\mathrm{Na}$ cela de uma cadeia \\ Foi que vi pela primeira vez \\ As tais fotografias \\ Em que apareces inteira \\ Porém lá não estavas nua \\ E sim coberta de nuvens... \\ Terra! Terra! \\ Por mais distante \\ O errante navegante \\ Quem jamais te esqueceria?"
}

https://www.letras.mus.br/caetano-veloso/44780/ 
A professora repetiu o trecho algumas vezes e, logo após, falou aos estudantes: "Onde estava o homem que está cantando?", e os alunos responderam "Na cadeia", e ela continuou "O que este homem viu quando estava preso?" e as crianças responderam que foi uma foto da Terra. E então a professora indagou-os: "Quando foi possivel observar a Terra pela primeira vez do espaço?".

A princípio os alunos se mantiveram em silêncio. Ficaram em dúvida. Tentaram dizer que foi neste dia em que o homem estava cantando, mas precisavam de uma informação mais concreta. Não sabiam responder. Então a professora sugeriu anotar na lousa a pergunta para eles tentarem descobrir a resposta e tornou a perguntar: "O que o poeta quis dizer com a frase: "Porém lá não estavas nua, e sim coberta de nuvens..." Os alunos novamente começaram a refletir... O aluno 15 perguntou o que era a palavra "nua" e a professora disse que "era estar sem roupa", então eles riram, afinal "a Terra não usa roupa". A professora orientou a turma a tentar compreender o que o poeta quis dizer com essa expressão. Os alunos passaram a debater, e o aluno 6 falou "a Terra tem as nuvens, e essa é a roupa", seguido dele outro aluno disse " $A$ foto da Terra mostra as nuvens, que são a roupa que a Terra tem".

A professora concordou $\mathrm{cm}$ as crianças e disse a eles que o primeiro homem a sair da Terra, e circundar nosso planeta foi Yuri Gagarin, em 12 de abril de 1961. E assim que ele pôde sobrevoar o planeta disse a famosa frase "A Terra é azul". Foi a este dia que o compositor Caetano Veloso estava se referindo na música. Dando continuidade a professora apresentou a turma um vídeo com imagens do planeta Terra: https://www.youtube.com/watch?v=aMwE5J9ImWY, explicando que há apenas 57 anos é que a humanidade foi capaz de ver uma foto da Terra.

Ao terminar de assistir ao vídeo foi perguntado aos alunos o que eram as luzes coloridas na superfície do planeta, e eles começaram a tentar responder; o aluno 19 disse que eram luzes do céu, mas foi interrompido pelo aluno 8 que disse "São as auroras boreais". Os outros estudantes concordaram com o colega. A professora aproveitou esse momento para fazer a socialização da lição de casa, perguntando aos alunos se eles haviam encontrado as informações. Coletivamente ela foi realizando a correção.

Terminado esse bate-papo inicial, ela propôs aos estudantes a leitura compartilhada do texto: "Terra, nosso planeta", disponível no Apêndice. 
O objetivo desta leitura era fazer uma análise investigativa do texto com os estudantes, por este motivo a professora solicitou que eles utilizassem marca-texto para grifar as informações que considerassem importantes durante a leitura.

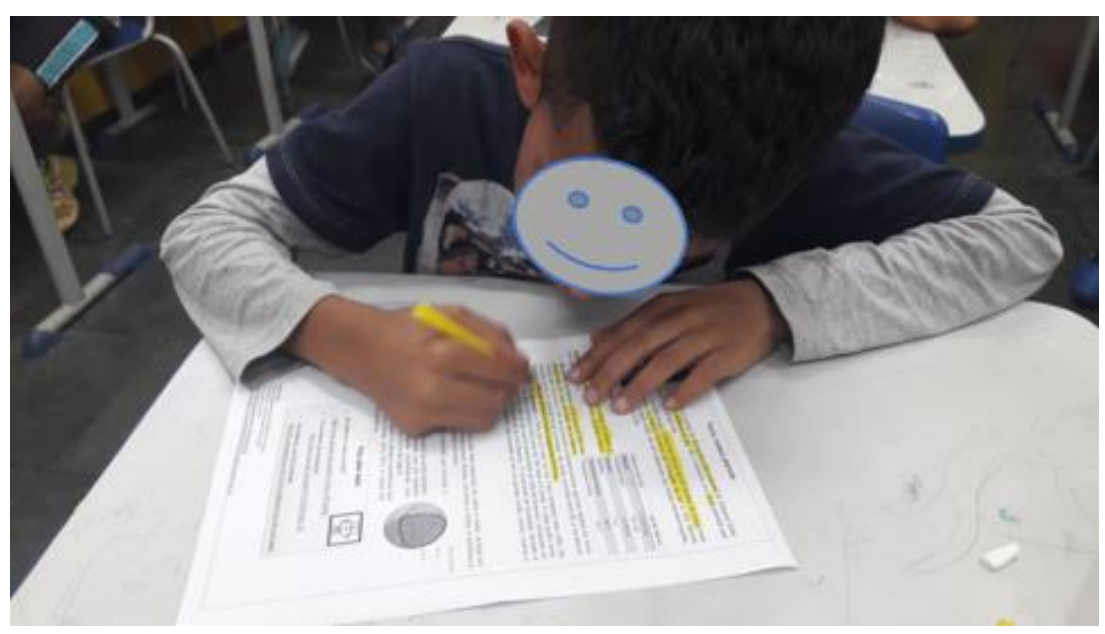

Figura 10 - Estudante selecionando informações no texto

Ao final da leitura a professora sugeriu que os alunos realizassem a leitura novamente, mas agora individualmente, e que cada um grifasse as informações que considerava mais importantes em cada parágrafo.

Para finalizar esta aula, a professora sugeriu duas atividades práticas para eles conseguirem observar os movimentos de rotação e translação da Terra.

A professora organizou os estudantes em grupos e distribuiu para cada um lanternas e uma bola de isopor. $\mathrm{Na}$ frente, a professora fez a demonstração da experiência pedindo o auxílio de um aluno que segurou o Sol, representado pela lanterna, enquanto a professora ia girando lentamente a Terra, representada pela bola de isopor. A professora procurou repetir este movimento ora para o lado esquerdo da turma, e ora para o lado direito, para que os grupos visualizassem o movimento adequadamente. Terminada a demonstração, ela permitiu que os grupos realizassem a atividade. Enquanto os grupos faziam o experimento, a professora circulou por eles, para garantir que todos estavam compreendendo e fazendo a reprodução de forma adequada. A professora ressaltava com os grupos que à medida que a Terra ia girando progressivamente uma parte ia sendo iluminada (ocasionando o dia) e ao mesmo tempo uma parte ia ficando no escuro (ocasionando a noite). 


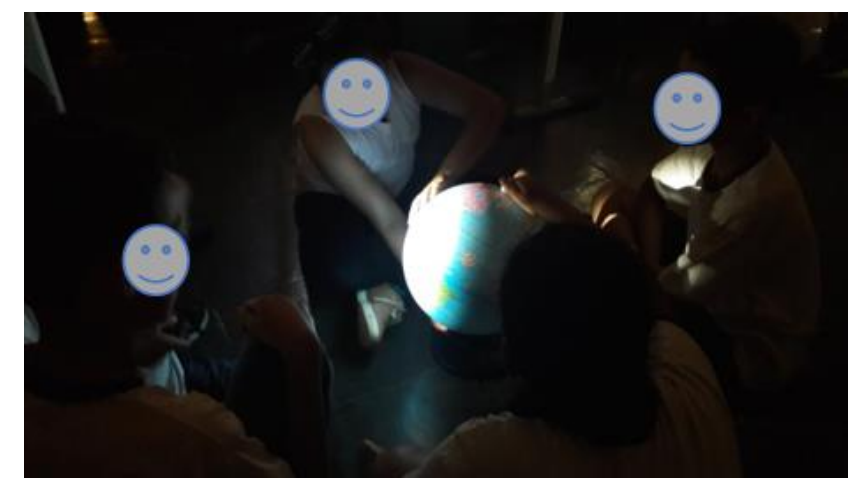

Figura 11 - Estudantes representando a noite e o dia com o globo terrestre

Para concluir a aula a professora propôs à turma o último experimento do tema. Organizou os alunos em uma grande roda com uma luminária no centro. Procurou-se deixar o espaço o mais escuro possível, com as luzes apagadas e as cortinas fechadas. Ela pegou o globo terrestre e orientou que ele fosse "passando" de mão em mão até chegar ao ponto de partida. Feito isto a professora explicou que ocorreu uma volta completa ao redor do Sol, ou seja, que a Terra tinha completado o ciclo de um ano, por meio do movimento de translação. A professora propôs então que um dos alunos levantasse e girasse em torno da Terra, fazendo no globo o movimento de rotação também, isso demonstrou que há uma diferença grande entre a rotação (girar em torno do próprio eixo) e translação (girar em torno do Sol). Os alunos foram instigados a pensar o que acontece com a Terra na sucessão dos dias e das noites, assim como com a translação em torno do Sol.

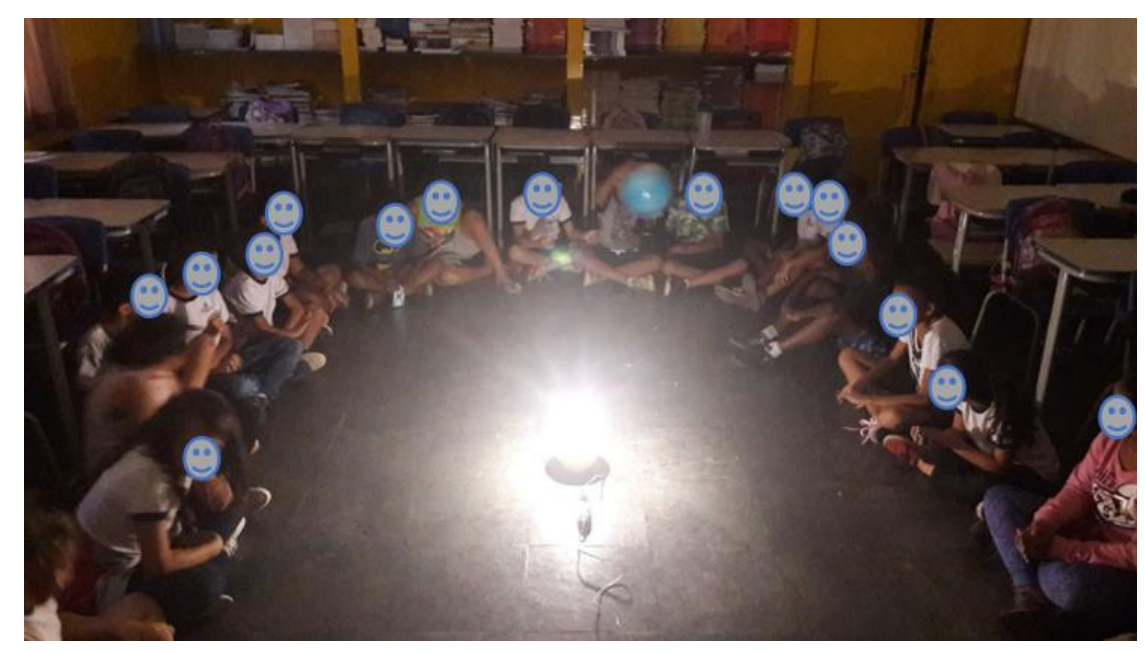

Figura 12 - Estudantes representando o movimento de translação 
Ao terminar a aula, a professora pediu para os alunos levarem de lição de casa uma atividade de interpretação sobre a Lua.

\subsection{Aula 6 - A Lua (1 ${ }^{\text {a }}$ etapa $)$}

Iniciou-se a aula, com a professora colocando a música "A Lua", do grupo MPB4, e entregando uma cópia da letra. Como os alunos realizaram uma lição de casa de interpretação de texto, com a letra dessa música, logo eles conseguiram identificar do que se tratava. Em seguida, a professora foi realizando coletivamente uma correção das questões propostas na atividade, que estão descritas a seguir:

1) Leia um trecho da música abaixo para responder as questões a seguir:

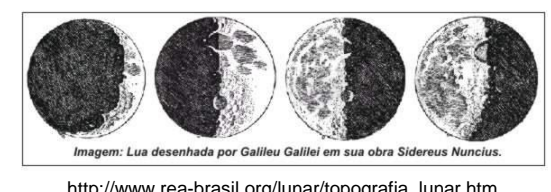

http://www.rea-brasil.org/lunar/topografia_lunar.htm

A Lua

MPB-4

A Lua
Quando ela roda
É Nova!
Crescente ou Meia
A Lua!
É Cheia!
E quando ela roda
Minguante e Meia
Depois é Lua novamente
Diiiizz!...

Quando ela roda

É Nova!

Crescente ou Meia

A Lua!

É Cheia!

E quando ela roda

Minguante e Meia

Depois é Lua-Nova...

Mente quem diz

Que a Lua é velha..

Mente quem diz!

https://www.letras.mus.br/mpb4/47527/ - Último acesso em 22/04/2018.

a) O que acontece com a Lua, nas diferentes situações, quando ela roda?

b) Você já reparou que a aparência da Lua muda de forma?

$>$ Desenhe abaixo a Lua em uma das formas que você já observou no céu. Você sabe como ela se chama nessa fase? Se sim, escreva como ela é popularmente chamada.

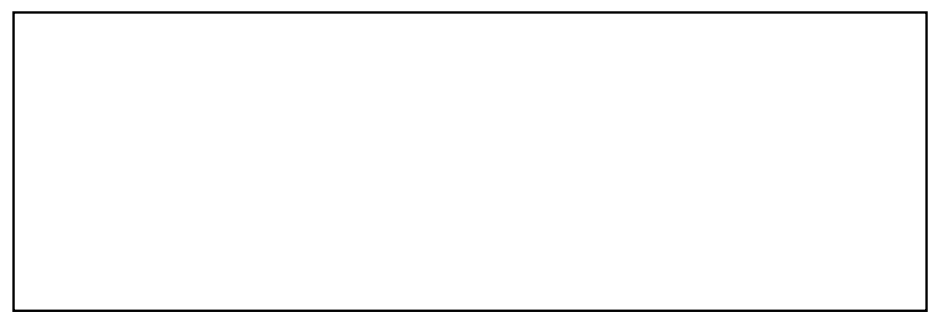

c) No trecho "Mente quem diz que a Lua é velha", você concorda com esta frase? Por quê? 
Durante a atividade, a professora conseguiu realizar já um levantamento dos conhecimentos prévios dos alunos acerca de informações sobre a Lua. Dando continuidade à aula, foi exibido o filme "Viagem a Lua", de George Méliès, disponível em: https://www.youtube.com/watch?v=leXpc2vBG-w $\quad$ (aproximadamente 15 minutos).

A professora explicou aos alunos que este vídeo foi criado em 1902, e foi um dos primeiros de ficção científica a serem feitos. Também explicou aos alunos que durante a exibição do filme ela iria fazer pausas para conversar sobre os trechos, como descrito a seguir:

- Nos primeiros 2 minutos de exibição a professora questionou os alunos sobre o que as pessoas estavam fazendo. Ajudou-os a concluir que estavam fazendo uma reunião. E que há um personagem que está dando explicações, fazendo anotações no quadro.

- Em 2'43" a professora perguntou aos alunos qual era o assunto desta reunião (ir à Lua, já que o "palestrante" desenha a trajetória de um foguete até o satélite). A professora ainda questionou os alunos sobre a reação das pessoas presentes;

- Em 2'58" pergunta-se: O que acontece na reunião? Será que todos concordaram com a ideia? Por que será quem nem todos concordaram com a ideia?

- E 3'33" pergunta-se: O que acontece com os demais participantes ao "darem o aperto de mão"? O que isto significa?

- Em 4'28" a professora questionou os alunos: O que está acontecendo? Esperase que os alunos digam que se inicia a construção de um foguete para levá-los à Lua.

- Em 5'48" a professora pergunta aos estudantes o que irá acontecer, esperando que eles identifiquem que é o dia do lançamento do foguete. $O$ dia da tão esperada viagem à Lua;

- A professora pausou o vídeo em 7'29 e perguntou aos alunos se esta viagem daria certo e por quê. Em seguida, continuou a exibição.

- Aos 8'00" pausou novamente o vídeo e permitiu que os alunos falassem o que pensavam. Por que a Lua tem olhos e boca? Por que saiu sangue da Lua? A 
professora ainda perguntou o que eles achavam que aconteceria agora. Em seguida retomou a exibição do filme.

- Em 8'45" a professora questionou: O que os personagens visualizam ao fundo? Eles identificaram que era o planeta Terra.

- Em 11'13" a professora pergunta: O que é isto? Os alunos identificaram que tinha um habitante da Lua.

- Em 12'15" a professora pergunta: "Que lugar é este? O que existe na Lua?" e os alunos identificaram que existia um reino na Lua;

- Finalizou a exibição do vídeo com o retorno dos aventureiros à Terra.

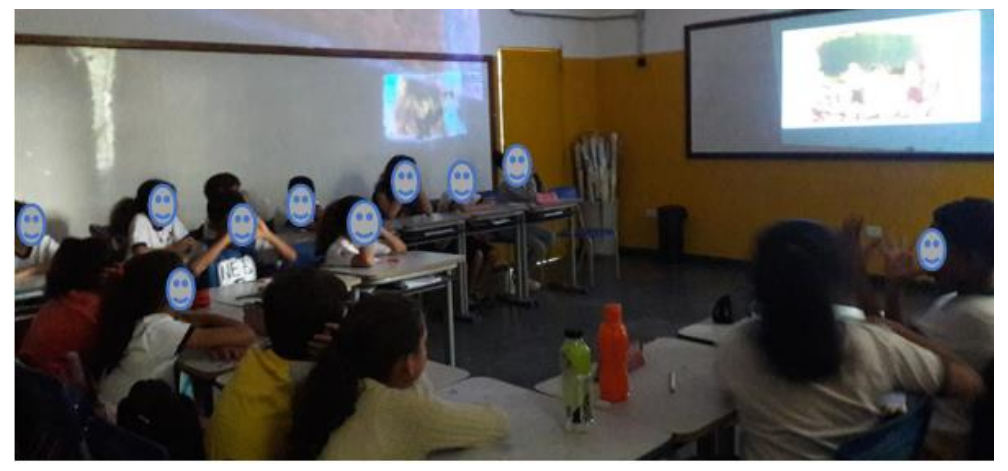

Figura 13 - Alunos assistindo ao filme

Ao finalizar a exibição do filme a professora incentivou os alunos a refletir sobre o interesse da humanidade em conhecer e conquistar a Lua, desde muito tempo. $E$ até $\mathrm{o}$ homem conseguir ir à Lua, muitas histórias, mitos e crenças povoavam a imaginação das pessoas. Inclusive foram feitos filmes e livros com esta temática, imaginando existir outro mundo lá.

A professora aproveitando essa reflexão, perguntou aos estudantes: $O$ que vocês gostariam de saber sobre a Lua?

Ela anotou na lousa cinco perguntas que os alunos formularam, e explicou que eles iriam realizar uma leitura compartilhada de um texto sobre a Lua, e se não descobrissem durante a leitura aquelas perguntas eles iriam pesquisar as respostas como lição de casa.

A figura 14 mostra as perguntas elaboradas: 


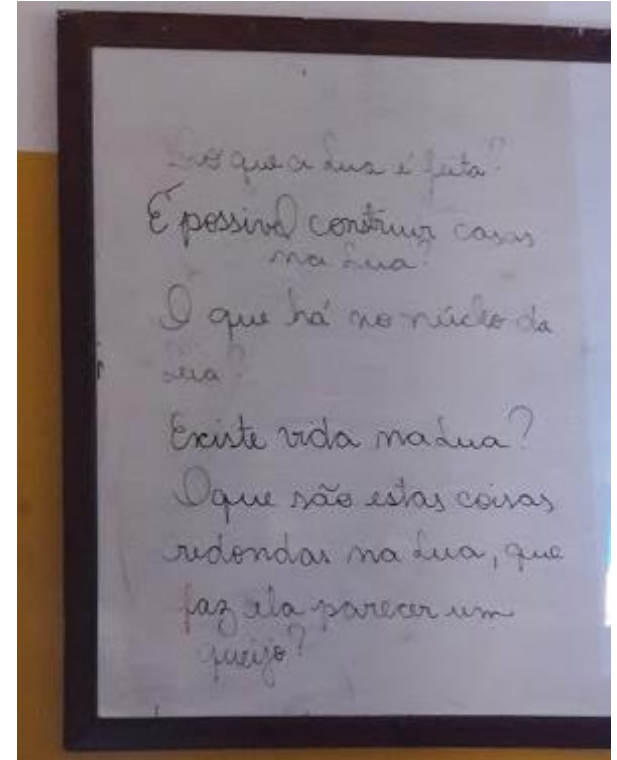

Figura 14 - Perguntas elaboradas pelos estudantes sobre a Lua
- Do que a Lua é feita?

- É possível construir casas na Lua?

- O que há no núcleo da Lua?

- Existe vida na Lua?

- O que são estas coisas redondas na Lua, que fazem ela parecer um queijo?

Dando continuidade a aula, a professora apresentou aos alunos mais dois vídeos, mas antes de exibi-los, ela os orientou a assistirem atentamente, porque depois eles fariam comparações entre estes dois vídeos e o que assistiram primeiro, o Viagem à Lua, de Georges Méliès.

- A simulação da viagem à Lua em 1969, com algumas imagens reais do pouso em nosso satélite natural https://www.youtube.com/watch?v=Pht19m8HJxM - 7'44"

- Um documentário com imagens reais da viagem https://www.youtube.com/watch?v=5dfmNroYvZ0 - 10'33"

Ao término dos dois filmes, a professora fez as seguintes perguntas à turma:

1) Quais semelhanças podemos encontrar entre os três vídeos?

2) Quais diferenças?

3) No primeiro filme existiam habitantes na Lua. O que se descobriu quando puderam visitá-la?

4) Por que não há vida na Lua? 


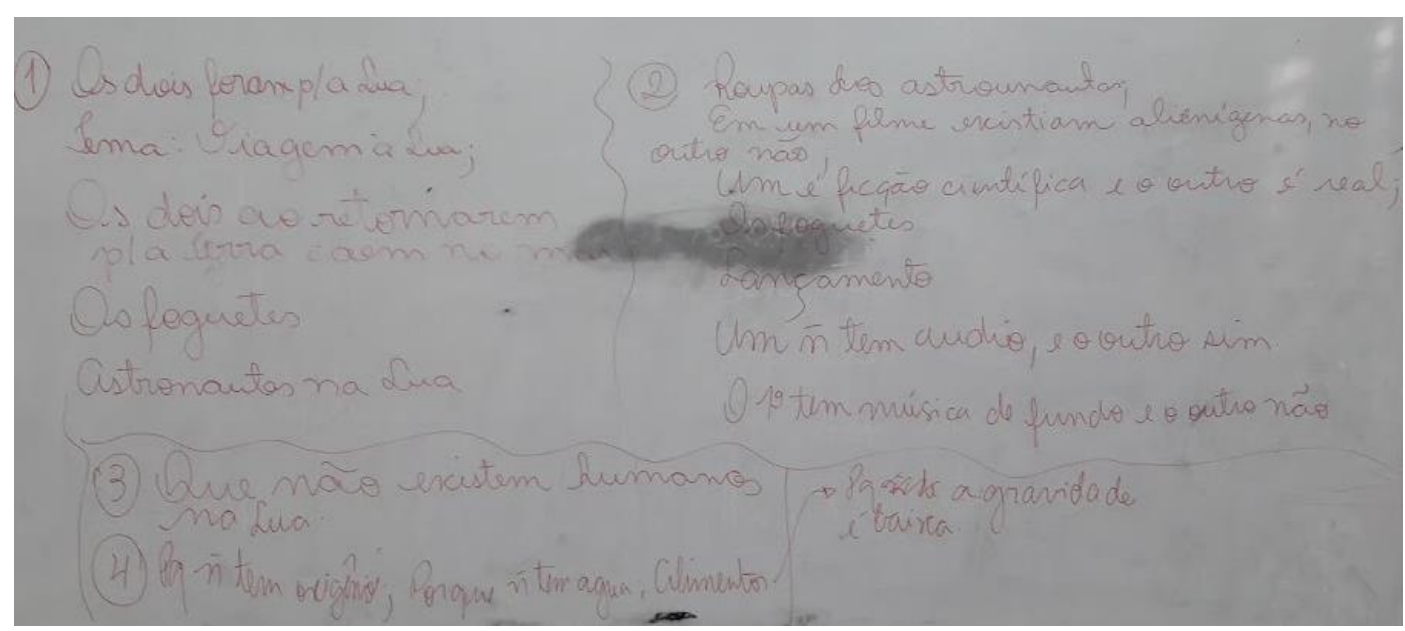

Figura 15 - Diferenças e semelhanças apontadas pelos alunos acerca dos vídeos assistidos

Finalizou-se esta primeira etapa da aula, e não foi encaminhada nenhuma lição de casa.

\subsection{Aula 6 - A Lua (2ª etapa)}

A professora retomou a aula sobre a Lua, mas agora propondo a leitura compartilhada de um texto sobre o satélite. Antes da leitura, porém, ela retomou com a turma as perguntas que eles elaboraram na última aula sobre o astro:

- Do que a Lua é feita?

- É possível construir casas na Lua?

- O que há no núcleo da Lua?

- Existe vida na Lua?

- O que são estas coisas redondas na Lua, que faz ela parecer um queijo?

A professora combinou com a turma que eles iriam procurar no texto que ia ser lido, as respostas para as perguntas feitas, e o que não conseguissem descobrir iriam pesquisar posteriormente. 


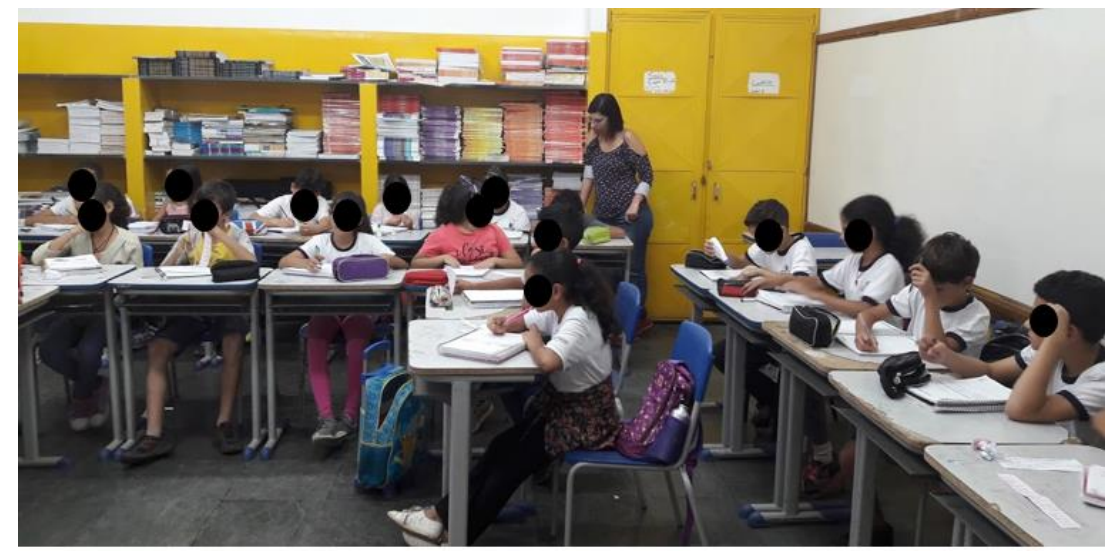

Figura 16 - Professora auxiliando os alunos na leitura do texto

Os alunos então realizaram a leitura entre duplas, grifaram no texto partes importantes e procuraram as respostas às perguntas elaboradas.

Terminado o prazo de leitura a professora perguntou a turma se tinham encontrado algumas respostas.

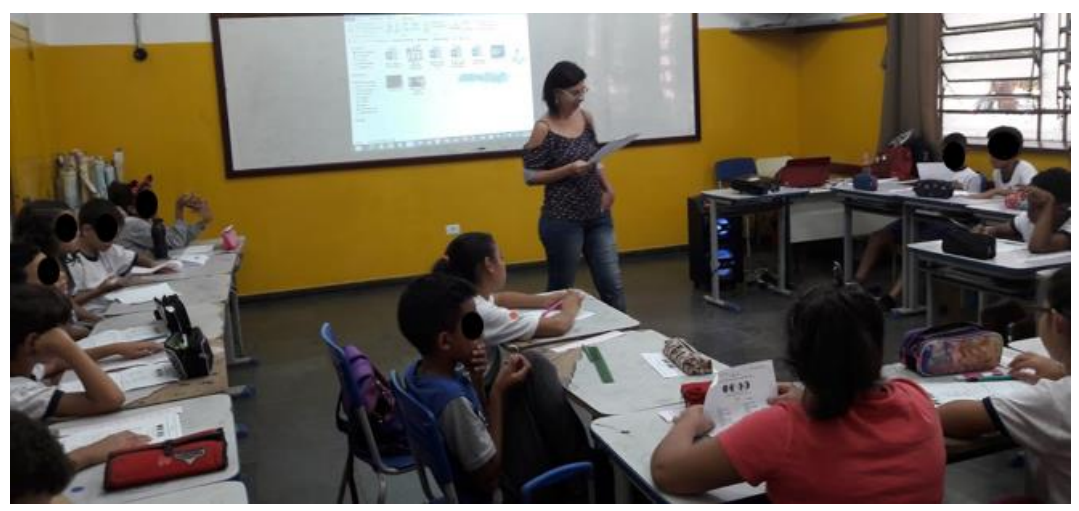

Figura 17 - Professora realizando a leitura compartilhada do texto

O aluno 32 disse que encontrou a resposta da pergunta "Existe vida na Lua?", outros colegas concordaram dizendo que também acharam, e que por não existir atmosfera e água no astro isso impossibilita a existência de vida.

O aluno 9 disse que descobriu a resposta da pergunta: "O que são estas coisas redondas na Lua, que faz ela parecer um queijo?", ele disse, "são as crateras, está escrito no texto". Um aluno discordou dele, dizendo que não dava pra ter certeza. Outros alunos disseram que não dava pra saber, entretanto o aluno 14 afirmou que viu na TV "que a Lua tem crateras, que são feitas pelos meteoros".

Combinou-se então que eles procurariam as respostas desta pergunta que eles estavam em dúvida e das outras que eles não conseguiram encontrar no texto. 
A professora então convidou a turma a realizar uma nova leitura, agora coletivamente, e ao parar em cada parágrafo eles diriam a ela o que grifaram e por quê.

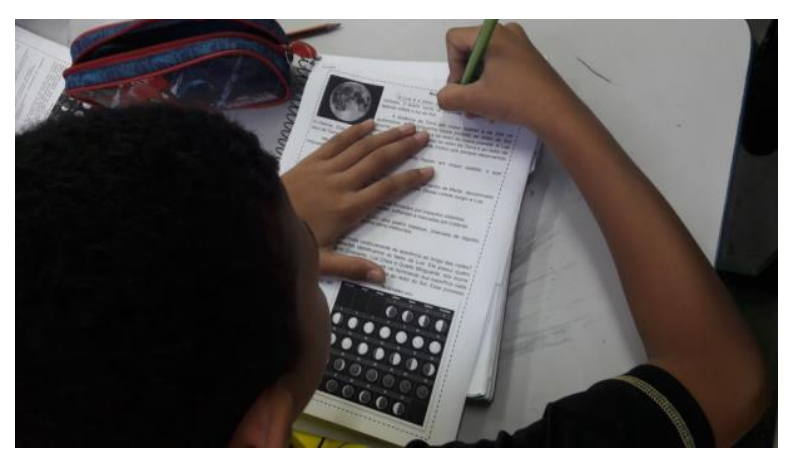

Figura 18 - Aluno grifando informações importantes no texto

Durante a leitura, os alunos destacaram várias informações importantes, entretanto a explicação das fases da Lua não era suficiente para garantir a compreensão da turma.

A princípio a professora sugeriu que a turma assistisse ao vídeo "Fases da Lua", da série $A B C$ da Astronomia https://www.youtube.com/watch?v=N2wTtaJEtNY $4 \min 18$ seg.

Para complementar o estudo final a professora trouxe um experimento já montado dentro de uma caixa de papelão com uma bola de isopor no centro, representando a Lua. Esta caixa possuía orifícios em diferentes posições que quando observados simulavam como vemos a Lua daqui da Terra durante a lunação.
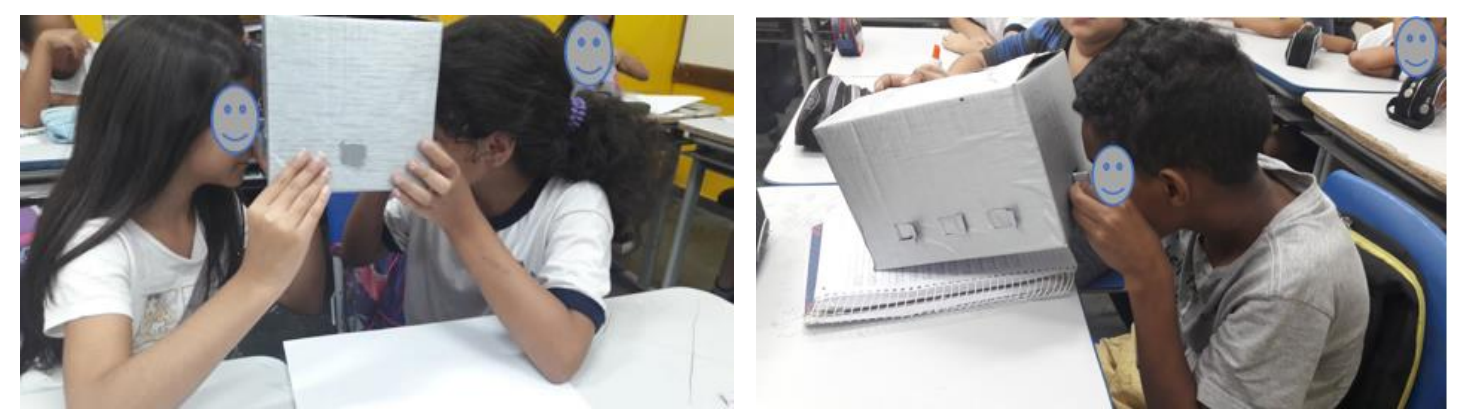

Figura 19 - Estudantes observando a simulação das fases da Lua

Os alunos foram observando as diferentes fases representadas e desenharam o que observaram e aprenderam. 


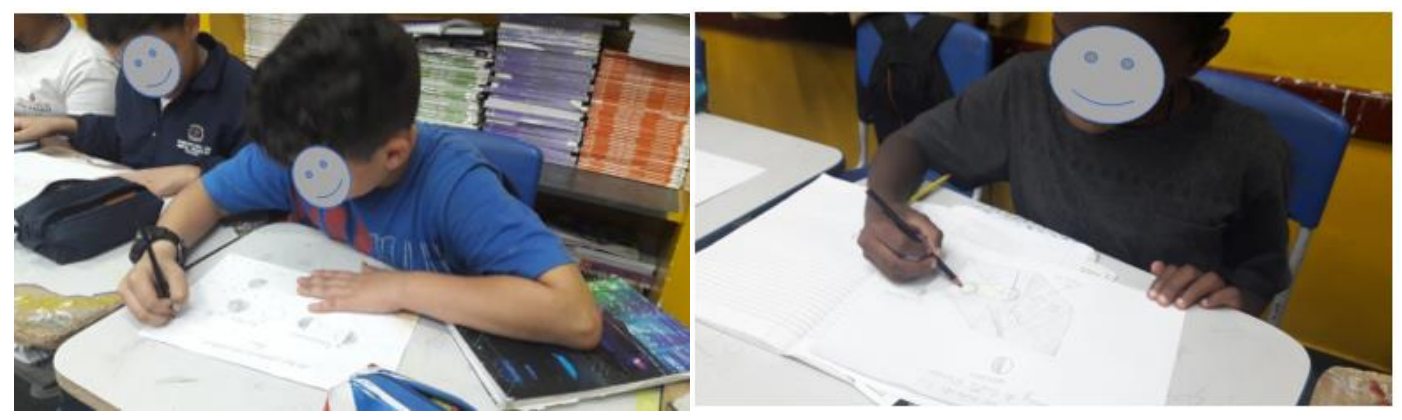

Figura 20 - Alunos desenhando o que observaram no experimento

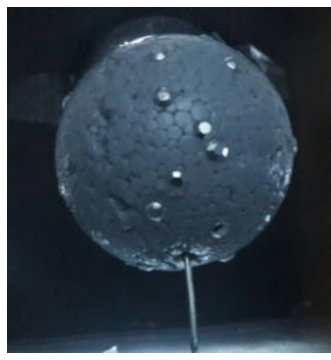

Lua Nova

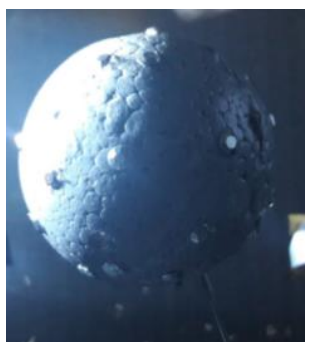

Lua Quarto Crescente

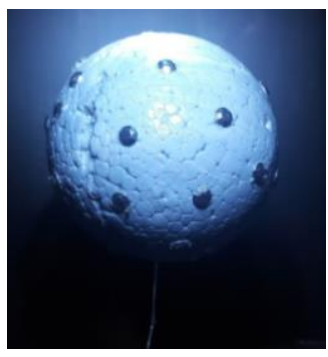

Lua Cheia

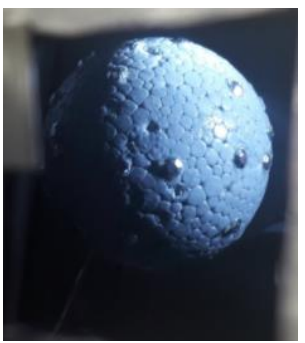

Lua Quarto Minguante

Figura 21 - Algumas imagens da simulação das fases da Lua

Após todos terem olhado o experimento, foi proposto que oralmente respondessem as seguintes questões:

1) Quais foram as fases da Lua que você conseguiu observar no experimento? Os alunos conseguiram citar as quatro fases principais Lua Nova, Lua Quarto Crescente, Lua Quarto minguante e Lua Cheia, entretanto a professora reforçou com os estudantes que cada dia a Lua apresenta uma aparência diferente.

2) Nas janelinhas intermediárias, como aparecia a iluminação da Lua?

Os alunos conseguiram explicar que em alguns momentos a "lua" estava mais iluminada, e em outros momentos menos iluminada.

3) É correto afirmar que a Lua cada dia apresenta um formato? Como você conseguiria comprovar isso com o experimento de hoje?

Os alunos conseguiram explicar de acordo com a reflexão da pergunta anterior, pois conforme a Lua vai girando ao redor da Terra, parte dela vai sendo mais ou menos iluminada para a nossa visão aqui da Terra (porque na verdade metade da Lua sempre é iluminada pelo Sol). 
Para finalizar a aula, a professora combinou com a turma que eles pesquisariam informações para responder as perguntas que não foram respondidas nas aulas sobre a Lua.

\subsection{Aula 7 - O Sistema Solar}

Antes de iniciar a aula a professora retomou com os alunos as perguntas sobre a Lua que eles deveriam pesquisar. Conseguiram encontrar as informações e ficaram satisfeitos. Sendo assim prosseguiu-se com o objetivo da aula.

A professora explicou que eles iriam aprender mais informações sobre o Sistema Solar, e que para isso, ela usaria o recurso de um vídeo (https://www.youtube.com/watch?v=IpHTVaFVUJw\&feature=youtu.be 13min24seg). Ela ainda explicou que eles assistiriam ao vídeo duas vezes, a primeira seria para eles apreciarem, e na segunda exibição eles poderiam anotar informações que acharam importante.

Ao fim da primeira exibição a professora permitiu que os alunos contassem suas impressões sobre o vídeo. Quais informações eles já sabiam e quais informações puderam descobrir, etc.

O aluno 25 disse que não sabia que o nome dos planetas era nome dos deuses romanos. O aluno 29 disse que não sabia que o tamanho dos planetas e do Sol era tão diferente, e que a Terra era tão pequena, "porque pra gente a Terra é gigante".

Seguindo a aula, a professora propôs uma leitura silenciosa do texto: "Nosso Sistema Solar", solicitando aos estudantes destacar as informações que julgam mais importantes. Terminada a leitura individual, a professora convidou os alunos a compartilharem as informações que encontraram, perguntando se mais alguém também tinha grifado a informação do colega.

Finalizada a primeira etapa, a professora explicou que ia projetar no quadro imagens dos planetas, e que os alunos poderiam fazer algumas perguntas sobre 0 que gostariam de saber sobre estes planetas. Ela combinou que poderia ser no máximo cinco perguntas para cada um, para não ficar muito extenso.

A seguir se apresentam as perguntas elaboradas pela turma, com a inclusão do planeta-anão Plutão, já que ele era fruto de muita curiosidade entre os estudantes. 


\section{MERCÚRIO}

1) O que são as "coisas" brilhantes em Mercúrio?

2) Existe água no planeta?

3) Qual é a sua temperatura máxima?

4) Já existiu vida nele?

5) O que há em seu núcleo?

\section{VÊNUS}

1) Por que chove ácido?

2) Por que é o mais quente?

3) Por que ele é o mais quente, se Mercúrio está mais próximo do Sol?

4) Por que ele se parece com o Sol?

5) O que existe em seu núcleo?

\section{TERRA}

1) Qual é a temperatura máxima?

2) Qual é a temperatura mínima?

3) Por que nele há vida e em outros planetas não?

4) Qual é a altura máxima das montanhas?

5) Por que a Terra tem gravidade?

\section{MARTE}

1) Por que ele tem características semelhantes à Terra?

2) Já existiu vida?

3) Chove em Marte?

4) Por que vamos mais pra Marte, se Vênus está perto da Terra também?

5) O que ele tem no núcleo?

\section{JÚPITER}

1) Por que ele tem uma mancha vermelha?

2) Por que ele é o maior?

3) O que há em seu núcleo?

4) Por que as cores nos polos são diferentes no centro?

5) Por que tem tantas luas?

\section{SATURNO}

1) Por que ele tem mais luas que a Terra?

2) Por que tem anéis?

3) Como se formou os anéis?

4) Ele gira como a Terra ou como Urano?

5) O que há em seu núcleo?

\section{URANO}


1) Por que chove diamante?

2) Por que ele é azul?

3) Neva nesse planeta?

4) Existem bichos? Seres vivos?

5) O que existe em seu núcleo?

\section{NETUNO}

1) O que são as manchas escuras?

2) Por que tem esta cor?

3) O que tem no núcleo?

4) Existe furacões?

5) Neva por ser muito frio?

\section{$\underline{\text { PLUTÃO }}$}

1) O que são as manchas pretas?

2) O que tem no núcleo?

3) O que ele é?

4) Por que ele virou anão?

5) Do que é feito?

6) Ele tem umidade?

Para finalizar a aula a professora orientou os alunos a montarem nove grupos, e cada um ficaria com um planeta para pesquisar as informações das perguntas elaboradas sobre os planetas. Ficou combinado para a aula seguinte que os estudantes começariam a montar um cartaz para apresentar as informações coletadas aos demais colegas.

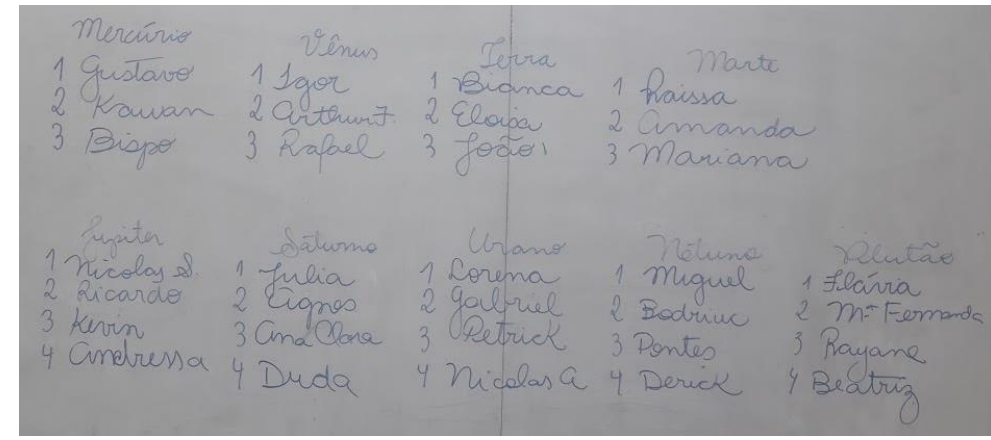

Figura 22 - Divisão dos grupos para a pesquisa sobre planetas

4.9 Aula 8 - Os planetas I - Trabalho em grupo

Nesta aula a professora participou pouco, pois os alunos era os responsáveis para confeccionar o cartaz. A professora apenas auxiliou os grupos a confirmarem informações ou esclarecer dúvidas sobre a pesquisa realizada. A professora também 
disponibilizou as enciclopédias para que os alunos pudessem utilizar para complementar sua pesquisa.

Como lição de casa os alunos deveriam ensaiar sua apresentação que seria na próxima aula.

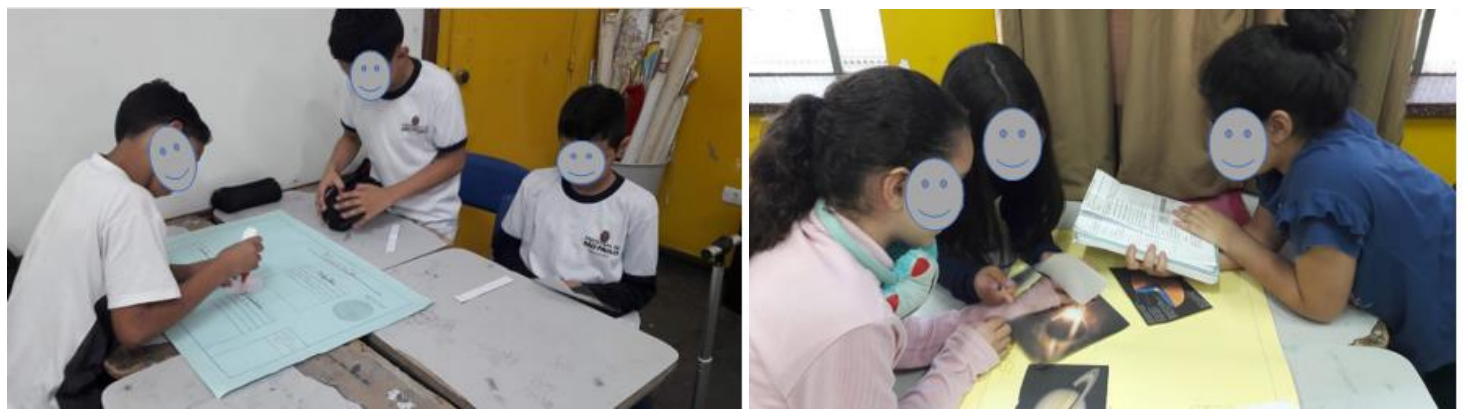

Figura 23 - Estudantes confeccionando cartazes sobre os planetas

\subsection{Aula 9 - Os planetas II - Trabalho em grupo}

Nesta aula os alunos foram organizados de um modo receptivo para que todos pudessem ouvir e visualizar bem os cartazes confeccionados para a apresentação e assim poder comunicar aos colegas o que aprenderam com suas pesquisas. Ao terminar as apresentações os alunos foram orientados a se juntarem ao seu grupo novamente para se autoavaliarem.

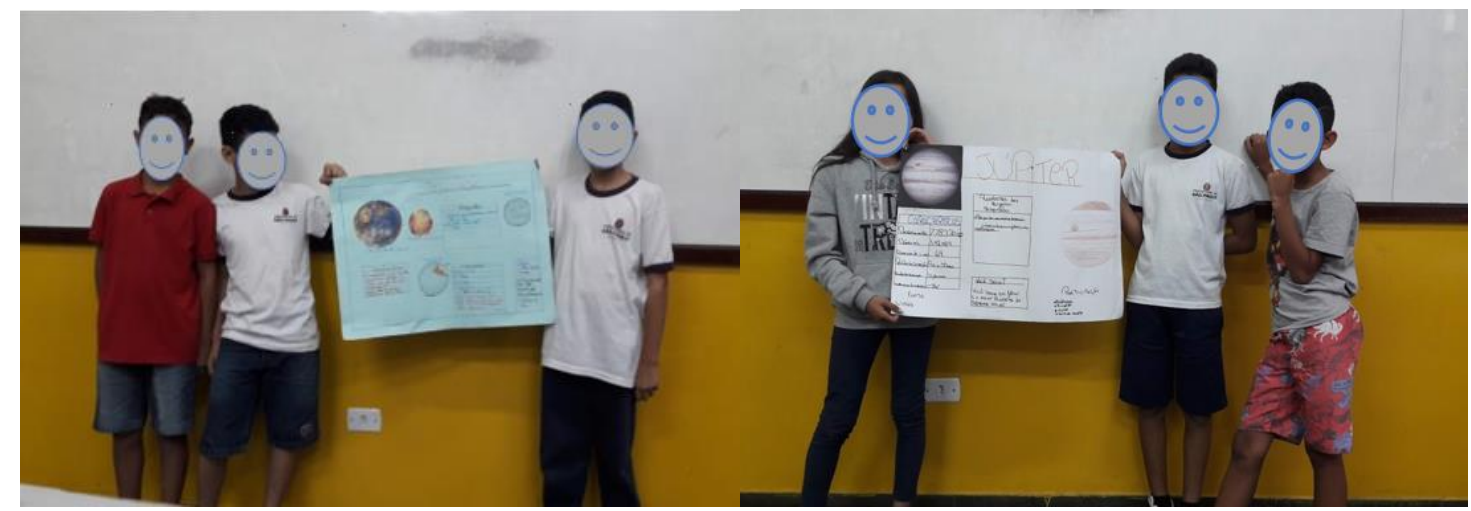

Figura 24 - Estudantes apresentando sua pesquisa 


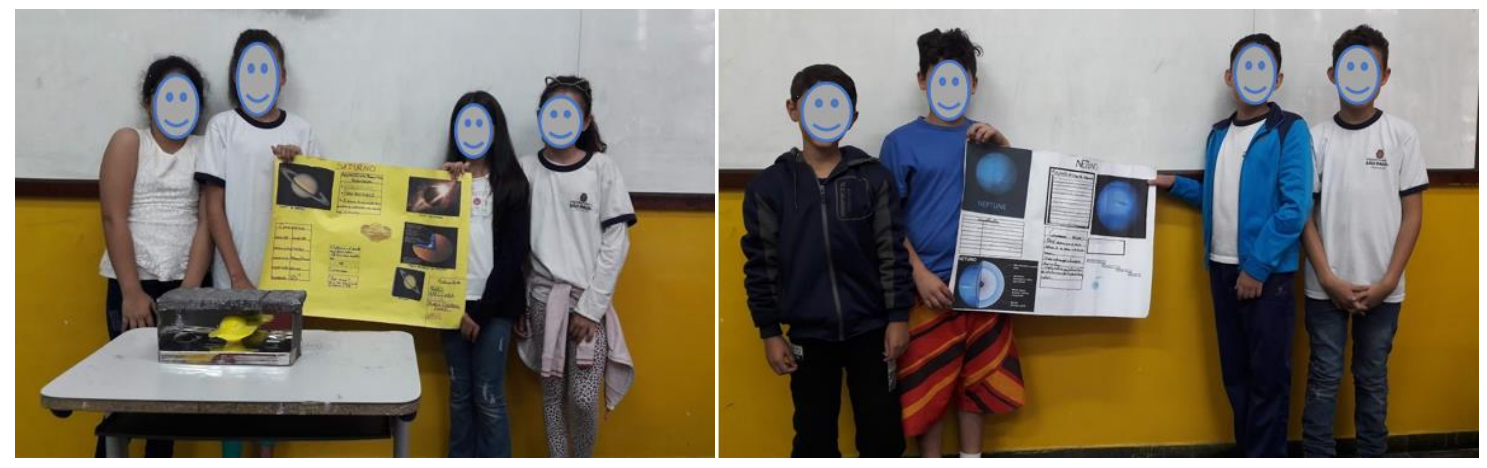

Figura 25 - Estudantes apresentando sua pesquisa

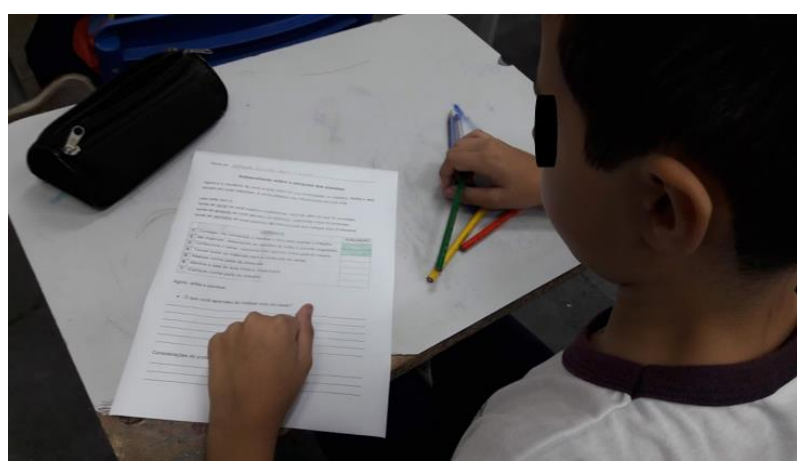

Figura 26 - Estudante preenchendo a autoavaliação

4.11 Aula 10 - Qual é o tamanho dos planetas?

Iniciou-se esta aula fazendo com os alunos uma retomada de várias informações que eles descobriram sobre os planetas. A professora questionou os estudantes, procurando descobrir o que eles já tinham aprendido.

Professora: Então, o que vocês podem me contar de informações que vocês aprenderam nas aulas sobre os planetas?

Aluno 5: Eu aprendi que Marte é o quarto planeta, e que ele é menor que a Terra. E que o nome dele é do deus da guerra, porque ele tem uma cor vermelha.

Professora: Puxa! Que legal! E tem mais alguém que quer contar algo que aprendeu? Você? Pode falar!

Aluno 31: Eu gostei de aprender tudo sobre os planetas. Eu achava que Júpiter era Saturno. Eu errei. E agora que eu fiz o trabalho de Júpiter eu sei que ele é o maior planeta de todos. Mas o Sol é bem maior.

Professora: É verdade! Alguém mais? 
Aluno 13: Eu gostei de saber que tem oito planetas, e que Plutão já foi planeta. Eu queria que ele voltasse a ser planeta, prô.

Professora: Ah, é verdade! Quando eu estava na escola, com a idade de vocês, Plutão ainda era planeta. Eu também fiquei triste com a mudança. Mas pensa assim, isso é apenas uma classificação. Plutão continua lá no espaço, e continua sendo um astro mega interessante, pra gente estudar!

Aluno 3: Eu achei que a gente não ia conseguir fazer o trabalho de Mercúrio, porque no começo a gente não conseguia uma foto dele. E depois deu certo. $O$ Mercúrio é pequeno, mas ele está perto do Sol e por isso é o mais rápido de todos.

Aluno 24: A gente aprendeu que o Mercúrio tinha asas nos pés, porque era $o$ deus mensageiro. Ele dá a volta no Sol primeiro que os outros, e por isso ele é quente. Mas ele não é o mais quente. O quente é Vênus.

Aluno 21: É quente (se referindo a Vênus) porque ele tem efeito estufa lá. E ele gira do lado diferente. Mas ele é muito lindo. $E$ a gente olha ele aqui da Terra e ele parece uma estrela.

Aluno 15: A estrela d'Alva! A estrela d'Alva!!! Ele é muito lindo. Por isso era o nome da deusa da beleza.

Professora: Parabéns, deu pra ver que vocês já sabem um monte de informações, não é? Eu queria convidar vocês a fazerem uma atividade agora pra gente conseguir entender melhor o tamanho dos planetas. Numa foto a gente não consegue ver os planetas inteiros, vocês lembram? Então, eu queria convidar vocês a fazerem os planetas num tamanho menor, mas proporcional, como se a gente desse uma poção para os planetas diminuírem de tamanho e daí a gente conseguiria enxergar eles direitinho. Vocês topam?

Os alunos concordam, então a professora começou a organizar a turma, orientando que eles se organizassem em grupos com quatro alunos.

Com os grupos montados a professora orientou-os de que receberiam massa de modelar e uma folha com círculos, com o tamanho em diâmetro já proporcional dos planetas. Ela foi demonstrando que eles deveriam fazer com a massa de modelar bolinhas que coubessem dentro do diâmetro mostrado na folha, e que não deveria ficar nem maior e nem menor. Para eles terem certeza se estava correto bastava olhar por cima, e verificar se aparecia o contorno do círculo envolta da bolinha. Ela ainda 
orientou os alunos a se dividirem e combinar quem faria cada planeta, para que todos conseguissem participar.

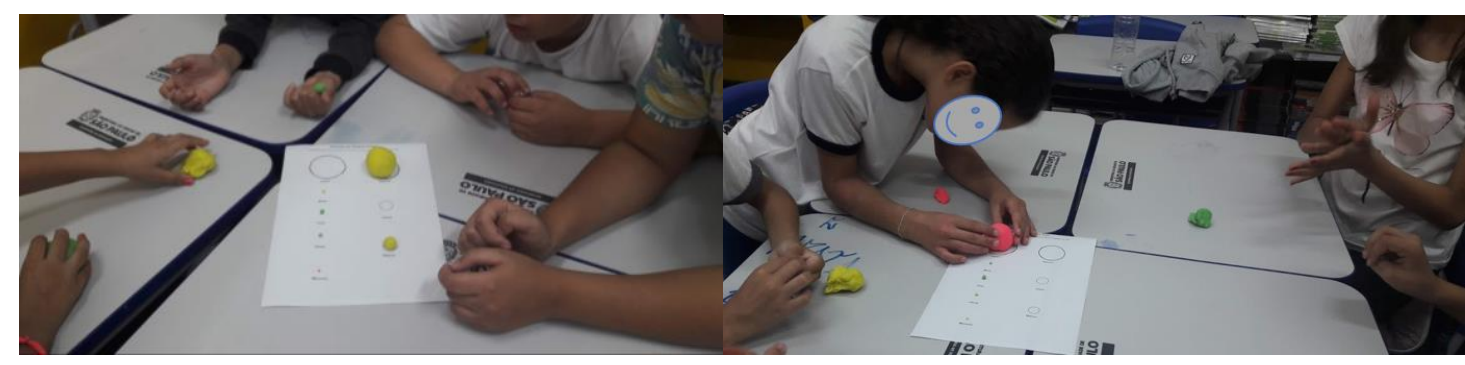

Figura 27 - Estudantes confeccionando os planetas com massinha de modelar

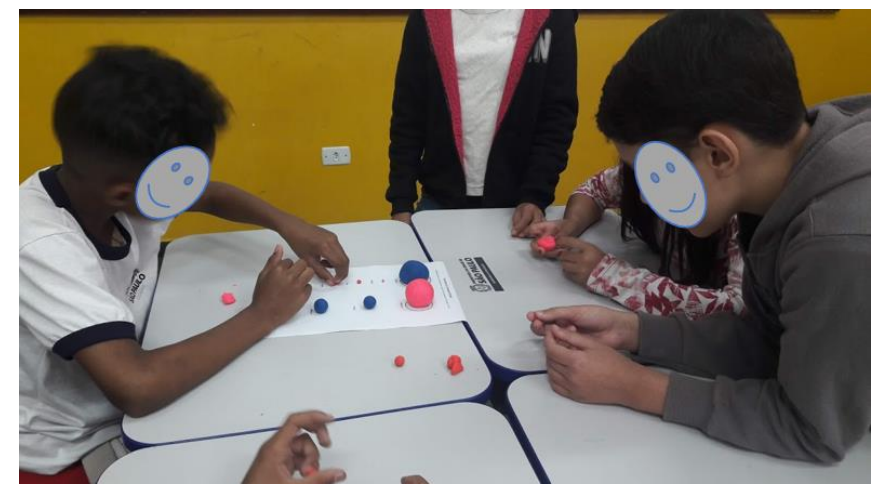

Figura 28 - Estudantes confeccionando planetas com massinha de modelar

Os grupos foram pouco a pouco fazendo as bolinhas, sem grandes dificuldades, entretanto os planetas menores deram trabalho, porque eram muito pequenos. Esse processo foi interessante, porque durante o trabalho os alunos já começaram a questionar se o tamanho da Terra estava correto. Para eles parecia difícil acreditar que a Terra era tão menor que Júpiter, mesmo já tendo assistido um vídeo com essa simulação.

O aluno 30 chamou a professora e perguntou: "Prô, mas é certo a Terra ficar desse tamanho? Porque ela tá muito pequena, e o mundo é grande!". Os demais colegas do grupo, concordaram com o colega, dizendo que ia ser difícil deixar Mercúrio redondinho, de tão pequeno que estava. A professora então decidiu fazer uma pausa para dar uma explicação a toda turma. 


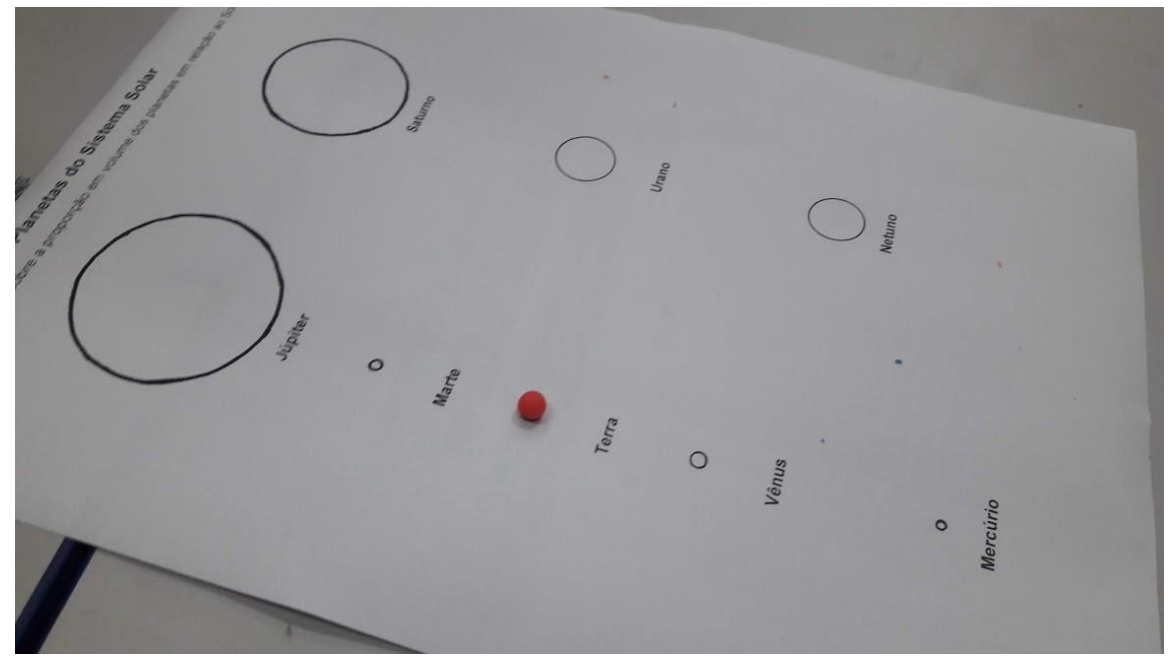

Figura 29 - Atividade sobre o volume dos planetas

Professora: Pessoal, presta atenção aqui um pouco... Podem parar e depois eu dou mais tempo para vocês terminarem. Os colegas desse grupo estão dizendo que a Terra está muito pequena, o que vocês acham?

Aluno 12: Olha, eu acho que tá errado sim!

E assim vários alunos concordaram.

Aluno 7: Eu acho que ela tá muito pequena mesmo, porque a Terra é muito grande. Olha só como Júpiter é maior. A gente vai gastar um monte de massinha pra ela, e pra Terra é muito pouco.

Aluno 18: Mas é porque a professora diminuiu tudo. E daí eles ficaram pequenininhos!

Professora: Pessoal, vocês lembram daquele vídeo que a gente viu o tamanho proporcional dos planetas? Quem era o planeta maior?

Todos: Júpiter!

Professora: Muito bem! Ele era o maior de todos, certo? Mas e quando o Sol apareceu? Júpiter ficou de qual tamanho?

Aluno 11: Ah, muito pequeno. Ele ficou um grão de feijão perto do Sol.

Professora: Exatamente! Em Astronomia as medidas são muito, muito, muito grandes. Elas são tão grandes que nós não conseguimos demonstrar o tamanho real de nada, porque tudo isso está fora da Terra... Vamos usar o exemplo do Sol. Quando vemos o Sol no céu, ele aparece pequeno, quase do tamanho da Lua, não é mesmo? Mas daqui da Terra, parece que quem é maior é a Terra e que o Sol e a Lua têm o mesmo tamanho. Mas nós sabemos que não é verdade. Nós sabemos que a Lua é 
menor do que a Terra e que o Sol é maior do que qualquer planeta. Agora, por que será que isso acontece?

Aluno 8: Não sei! Por quê, prô?

Professora: Vamos usar um exemplo fácil. Olhem para aquele carro estacionado lá embaixo do outro lado da rua. Se eu colocar os dedos para medi-lo ele ficará deste tamanho. Olha só! Aquele carro tem este tamanho?

Aluno 7: Não! Ele é maior que a gente!

Professora: Sim! Ele é maior! Mas o que o "transforma em menor" é a distância que ele está de nós. A medida que vamos nos aproximando ele vai ficando maior. É o que acontece com o Sol. A gente vê o Sol daqui da Terra com este tamanho porque ele está há aproximadamente 150 milhões de quilômetros de nós. Conforme vamos nos aproximando descobrimos que ele é muito maior. Por isso, vocês podem acreditar que o tamanho da Terra aí está proporcionalmente certo.

Desta forma, os alunos ficaram satisfeitos com a explicação da professora e puderam continuar o trabalho. Estavam interessados e queriam caprichar ao máximo.

Após todos os grupos terem terminado a confecção das bolinhas a professora pediu aos alunos que fizessem entre eles a comparação entre os tamanhos dos planetas. Enquanto isso ela pegava na sala dos professores uma bola com $80 \mathrm{~cm}$ de diâmetro que representaria o Sol, previamente preparada para esta finalidade.

Ao entrar na sala de aula com a bola, os alunos gritaram "O Sol", sem que a professora dissesse que se tratava da representação da estrela. A bola estava verdadeiramente muito maior que os planetas. Então a professora pediu para a turma se acalmar e ouvir.

Professora: Olha só, turminha! Muito bem! (aguardando o silêncio) Vocês acertaram sim! Esta bola irá representar o nosso Sol. Veja... (aguardando o silêncio) se pudéssemos reduzir o tamanho dos planetas e dos Sol para caber nessa sala eles teriam estes tamanhos. Veja o Sol comparado ao tamanho da Terra, olha como é diferente!

Os alunos estavam muito interessados e surpresos com os tamanhos tão diferentes. A euforia tomava conta da classe.

Professora: Agora, vou pegar Júpiter desse grupo. Olhem a diferença! 


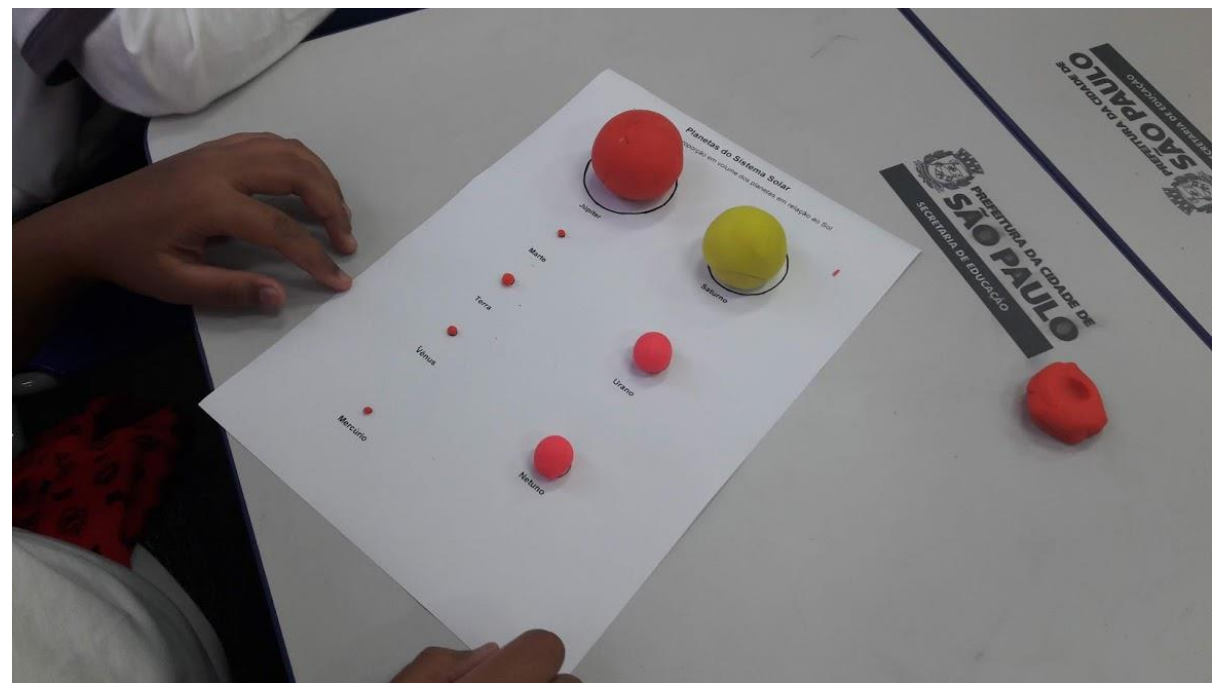

Figura 30 - Atividade completa sobre o volume dos planetas

Os alunos estavam entusiasmados, então a professora combinou de levar o Sol em cada grupo para eles olharem e compararam bem de perto. Combinou também para eles colocarem os planetas na ordem em que estão dispostos no Sistema Solar. E ainda recomendou:

Professora: Pessoal, olha só. Vocês estão colocando os planetas um do lado do outro pra gente comparar os tamanhos, mas lá no espaço, eles estão bem distantes entre si. Na próxima aula nós vamos descobrir um pouco sobre estas distâncias, combinado?

Desta forma, os grupos puderam comparar os tamanhos dos planetas em relação ao Sol e entre eles.

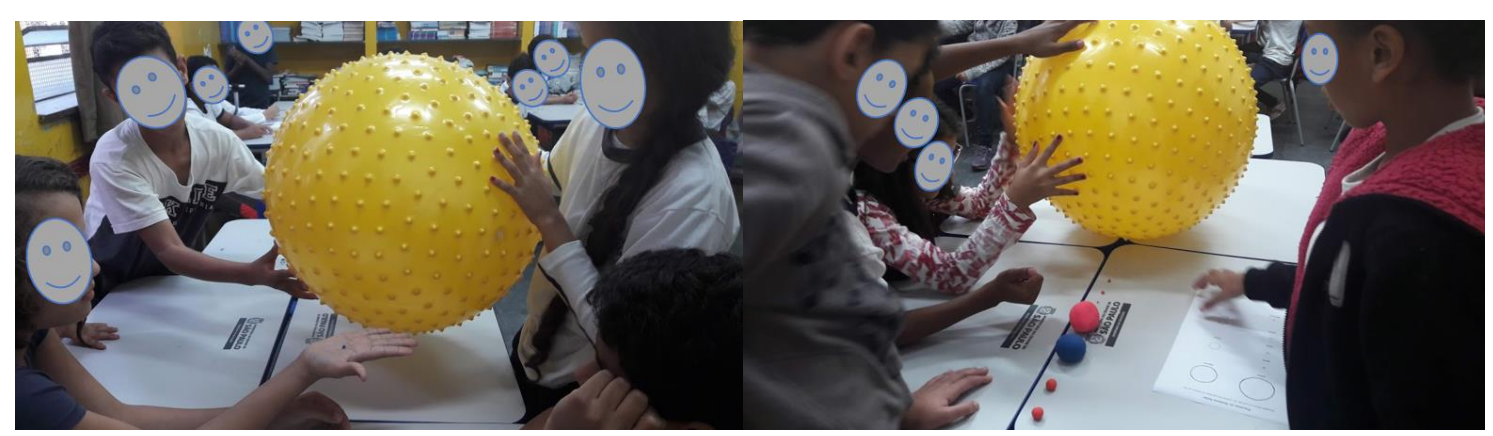

Figura 31 - Alunos comparando a diferença de tamanhos 


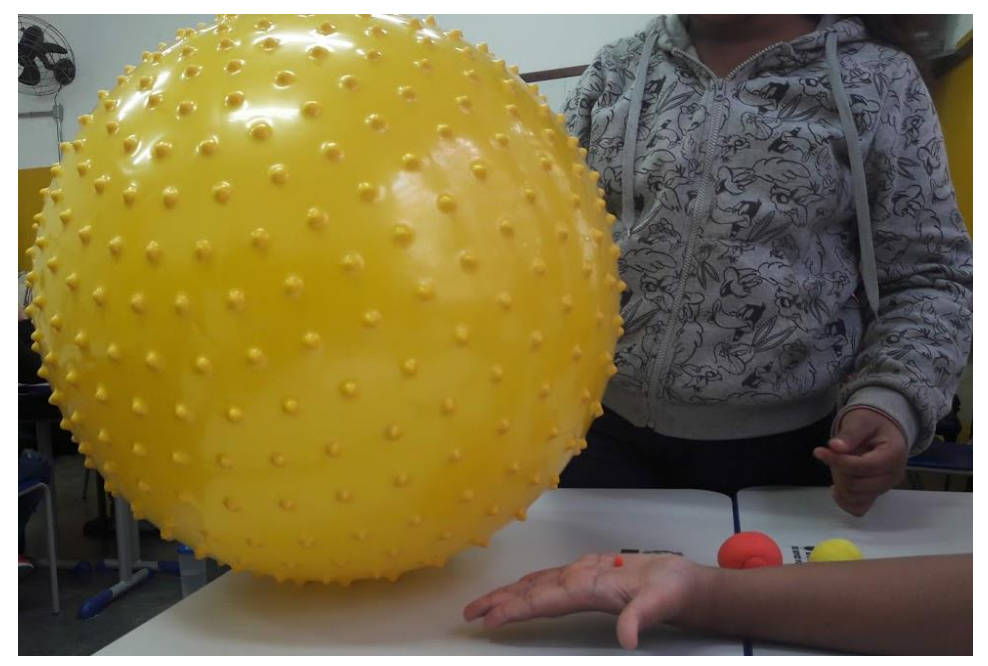

Figura 32 - Alunos comparando a proporção da Terra com o Sol

Para finalizar a professora pediu para os alunos fazerem um desenho de suas descobertas na aula.

\subsection{Aula 11 - Qual é a distância dos planetas?}

A professora iniciou a aula relembrando com a turma a atividade anterior, em que eles fizeram uma atividade para comparar o tamanho dos planetas e do Sol.

A professora inicia falando:

Professora: Bom, hoje a gente vai pensar nas distâncias dos planetas a partir do Sol. Vocês lembram que na última aula nós falamos dos tamanhos e que eu pedi para vocês deixarem os planetas em ordem a partir do Sol, alinhados um do lado do outro na mesa? Pois é... na verdade no espaço, essa configuração simplesmente não existe. Os planetas não se movem alinhados ao redor do Sol e nem estão tão pertinho um dos outros como nós colocamos aquele dia em cima da mesa. Veja estas fotos do Sistema Solar. Vocês estão vendo que os planetas estão um do lado do outro? Essa imagem é apenas uma representação para mostrar o Sol e os planetas porque se fosse uma foto real, nem Mercúrio ia caber dentro dela. Hoje nós vamos visualizar qual seria a distância dos planetas convertendo milhões de quilômetros em centímetros. Eu montei aqui usando fitas coloridas a distância já calculada, e vou colocar aqui no chão para vocês irem tendo uma ideia, combinado? Aqui vai ser o ponto de partida, o Sol (mostrando aos alunos onde estaria localizado o Sol no chão) É nesse ponto que nós vamos calcular a distância dos planetas. Vamos começar? 
A professora então colocou os alunos sentados no chão do pátio, formando um semicírculo e combinou com eles onde seria o ponto de partida. O primeiro planeta foi Mercúrio, e a professora disse: "Estão vendo? Mercúrio é o planeta mais próximo do Sol, ele está a aproximadamente a 57 milhões de quilômetros do Sol. Aqui na nossa simulação são apenas $5,7 \mathrm{~cm}$. Parece pertinho, não é?" Os alunos concordaram, mas a professora os alertou, dizendo: "Vejam só, estamos falando de distâncias gigantescas, que só podem ser medidas fora da Terra! Esse pequeno $5,7 \mathrm{~cm}$ não é nada comparado a 57 milhões de quilômetros. Isso é tão grande que pra nós humanos é muito difícil imaginar."

Os alunos interessados começavam a querer saber da Terra. Mas a professora disse que primeiro iriam ver a distância de Vênus. "Turminha, depois de Mercúrio vem Vênus. Ele está a aproximadamente 108 milhões de quilômetros do Sol. Será que aqui, quando a gente colocar, Vênus vai ficar mais ou menos onde?"

Cada aluno foi apontando para uma distância. Alguns muito longe e outro mais perto. Então a professora posicionou a fita no lugar adequado. Os alunos não ficaram muito surpresos, afinal não era tão distante assim, na percepção deles. Então a professora colocou as fitas da Terra e de Marte. Os alunos concluíram que não era tão longe assim.

A professora os desafiou: "Ah é? Vocês acham que não é tão longe assim? Uma viagem da Terra a Marte dura mais ou menos 1 a 2 anos. É perto ou longe?". Os alunos concordaram que era longe, mas ali no chão não parecia longe. Então a professora perguntou onde eles achavam que ficaria Júpiter. Os alunos apontaram um pouco mais para frente de Marte. Então a professora desenrolou a fita e os alunos ficaram muito entusiasmados "Ohhhh... nossa que longe!" A professora foi colocando os outros planetas e os alunos foram ficando surpresos como as distâncias maiores. Por fim, a professora quis mostrar a distância do Sol até o planeta-anão Plutão. E os alunos acharam muito legal. 


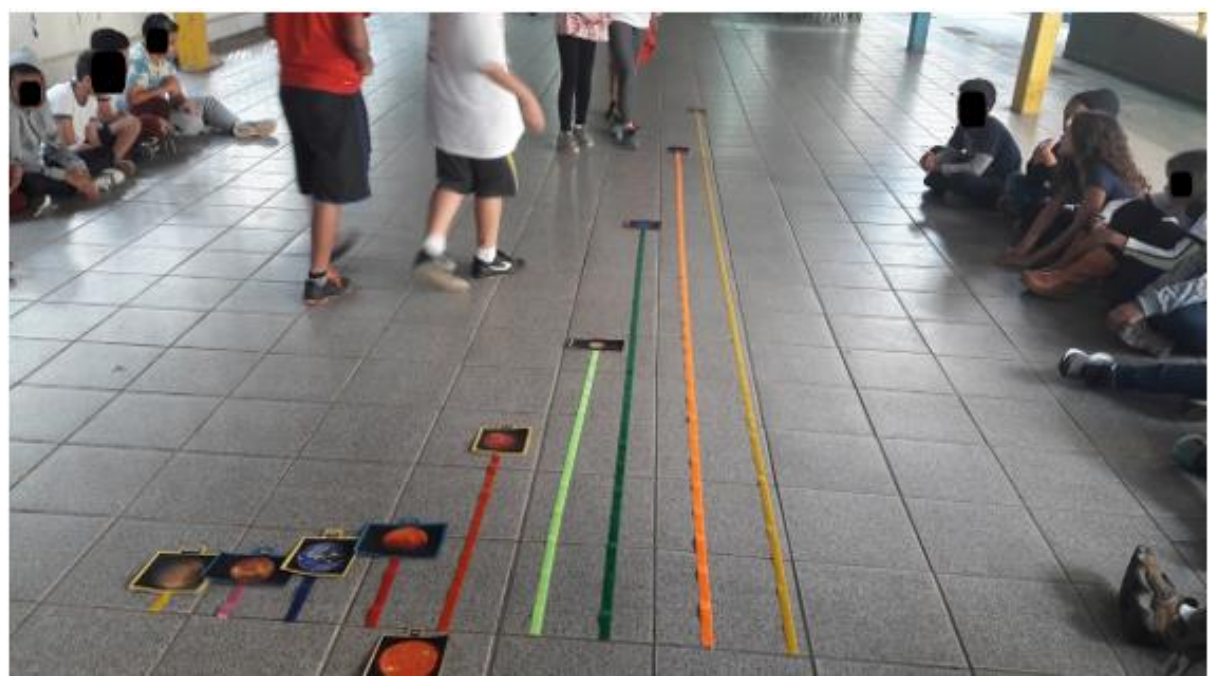

Figura 33 - Alunos observando as distâncias proporcionais dos planetas em relação ao Sol

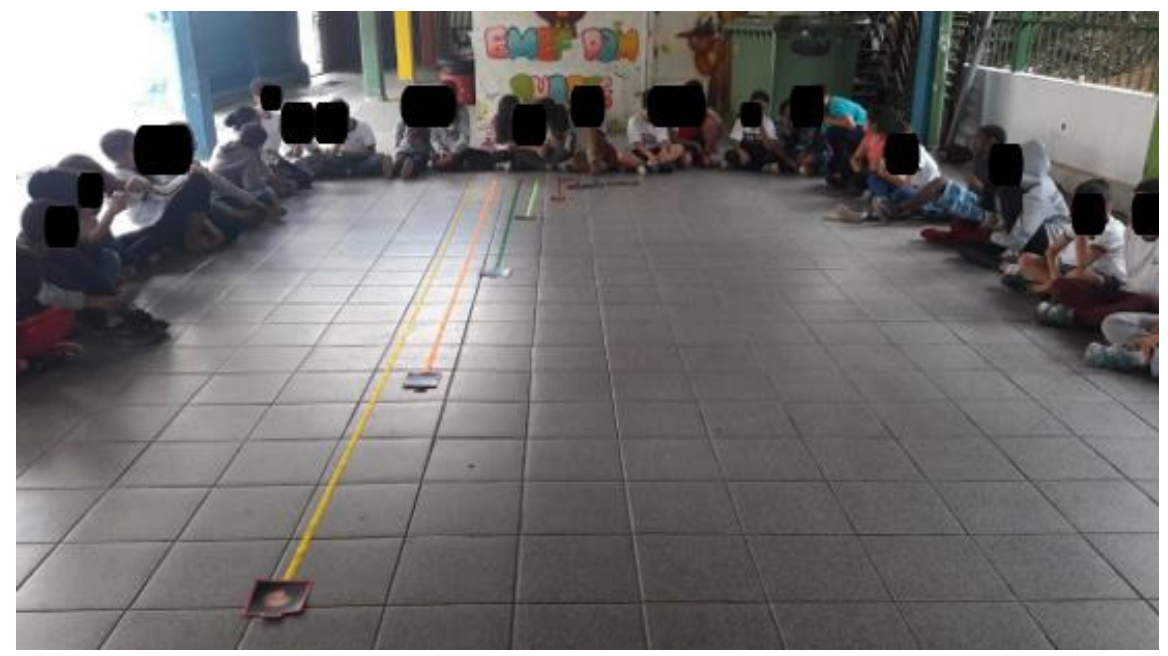

Figura 34 - Alunos reunidos para a realização da atividade sobre a distância proporcional dos planetas em relação ao Sol

A professora perguntou pra turma: "Agora vocês entendem porque essas fotos que eu mostrei no início da aula são apenas uma representação, e que os tamanhos e distâncias estão representados incorretamente?"

O aluno 2 levantou a mão e disse: "Prô, olha eu vi agora que tá longe. Então isso é muito grande mesmo. Porque aqui tá grande de olhar né?”. O aluno 16 concordou com o colega e disse que era longe mesmo e queria saber quanto tempo levava pra chegar em Plutão. A professora combinou que responderia na próxima aula, mas que ela achava que era aproximadamente 10 anos. $\mathrm{O}$ aluno 3 comentou que queria poder sair da Terra e conseguir olhar lá fora. Então a professora explicou, que vemos alguns dos planetas no céu a noite, mas que eles se parecem com 
estrelas. "Vênus é uma "estrela" mais brilhante que aparece no céu logo que amanhece ou que escurece durante o ano, e seu aspecto é de uma estrela linda! Marte, Mercúrio, Júpiter e Saturno nós podemos observar a noite, mas não desse jeito que vemos em fotos, e sim como pequenos pontos brilhantes. Se você saísse da Terra iria ver do jeito que vê aqui à noite. Estas fotos que nós vemos dos planetas foram tiradas por sondas e enviadas pra Terra. O ser humano nunca foi a um planeta, 0 máximo que conseguiram foi ir à Lua.".

Um aluno então comentou que ele tinha ouvido falar que vai ter uma viagem pra Marte. A professora concordou, disse que iria acontecer em breve, mas que mesmo assim é uma viagem arriscada, perigosa e difícil dizer se os tripulantes irão conseguir voltar pra Terra.

A professora perguntou a turma se eles tinham gostado da aula e contou que na próxima aula eles iriam jogar um jogo sobre o Sistema Solar.

\subsection{Aula 12 - Um jogo sobre o Sistema Solar}

Nesta aula os alunos foram convidados a jogar o jogo "Aventura pelo Sistema Solar". Trata-se de um jogo de tabuleiro, elaborado pela professora para esta atividade, em que podem participar de dois a quatro jogadores.

A professora iniciou a aula convidando os alunos a jogarem. A princípio cada grupo recebeu um jogo com todo o material necessário e coletivamente leram as regras:

\section{Jogo: Uma aventura pelo Sistema Solar}

Material necessário:

- 1 dado;

- 1 Tabuleiro do Jogo: Uma aventura pelo Sistema Solar;

- 1 conjunto de 40 cartas: Pergunta;

- 1 conjunto de 48 cartas: Você Sabia?

- 4 marcadores (pode ser confeccionado em EVA, feijões, ou qualquer outro material pequeno que sirva para marcar o percurso de cada jogador no tabuleiro);

- 50 estrelas (feitas em papel ou EVA).

Regras do jogo:

- De 2 a 4 jogadores;

- Os cartões Pergunta e Você Sabia? devem estar separados e embaralhados ao lado do tabuleiro, de cabeça para baixo;

- $\quad$ Os jogadores lançam os dados para decidirem quem inicia o jogo. 0 participante que tirar o maior valor no dado, inicia o jogo, e assim continuam os demais jogadores da esquerda para a direita; 
- Os jogadores devem atender as instruções das casas;

- Se cair em uma casa Pergunta, ou seja, a que possui o ponto de interrogação, ele deve respondê-la. Para isso, o jogador adversário seguinte, lê a pergunta, sem falar a resposta. Se o jogador acertar a pergunta, ganha a quantidade de estrelas que aparecem na carta. Se errar, permanece na casa em que está, aguardando sua vez de lançar o dado novamente.

- Se cair na casa Você Sabia?, lê as informações e lança o dado para fazer as orientações propostas na carta;

- $\quad$ Se aparecer a frase: Duelo de dados, os jogadores envolvidos lançam os dados e quem tirar a maior valor vence;

- Após realizar as instruções das casas ou das cartas, o jogador ao avançar ou retornar casas não precisa responder novamente os comandos. Somente quando lançar o dado na próxima vez.

- $\quad \mathrm{O} 1^{\circ}$ jogador a chegar ao final da jornada recebe 5 estrelas, $02^{\circ}$ recebe três estrelas, o $3^{\circ}$ recebe duas estrelas e o último recebe uma estrela;

- Os jogadores que terminarem a jornada devem aguardar todos chegarem ao final para realizar a contagem de estrelas e descobrir quem ganhou o jogo;

- $\quad$ Se houver empate na contagem de estrelas, os jogadores envolvidos lançam o dado novamente e quem tirar o maior valor vence.

Como se tratava de várias regras e esta seria a primeira vez que iriam jogar, a professora orientou os estudantes a iniciarem o jogo, e que conforme tivessem dúvida de procedimento a chamassem ou que relessem as regras.

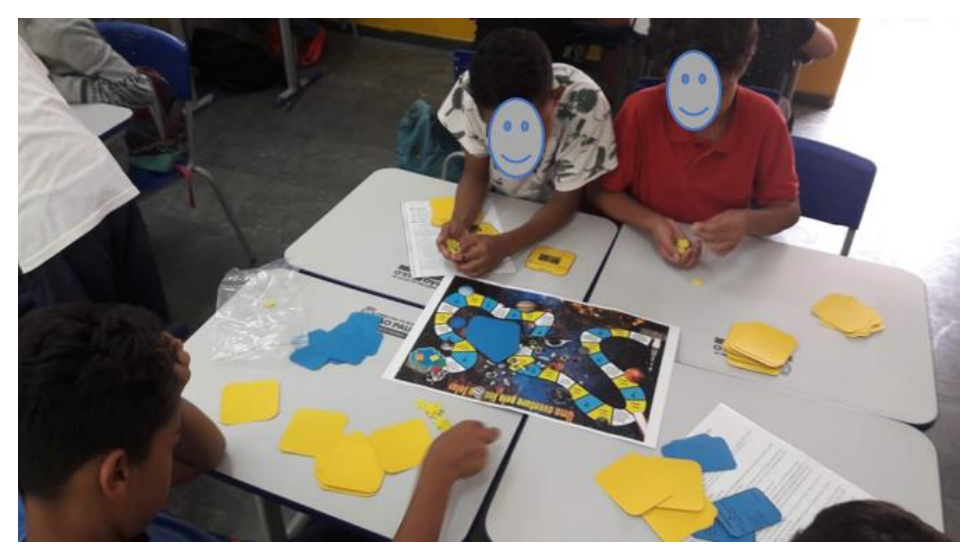

Figura 35 - Estudantes jogando "Uma aventura pelo Sistema Solar"

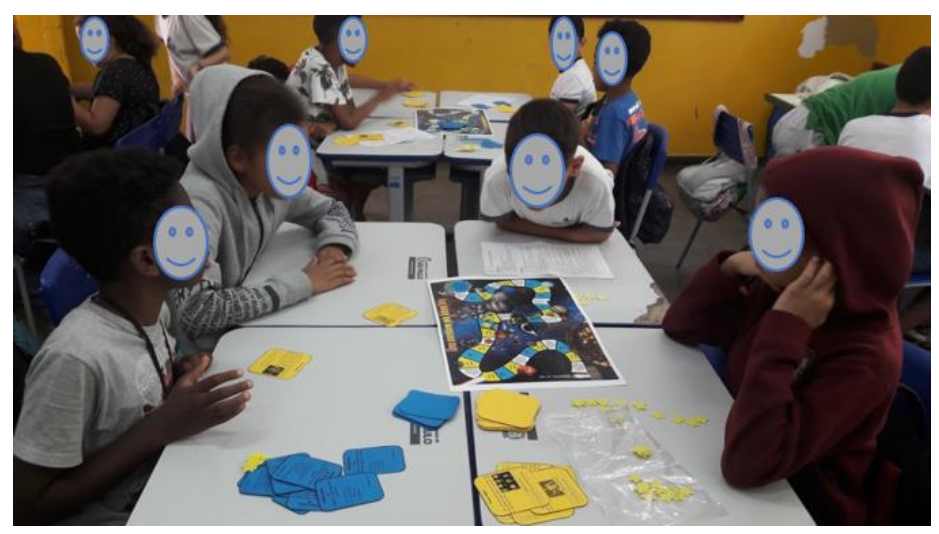

Figura 36 - Estudantes jogando "Uma aventura pelo Sistema Solar" 


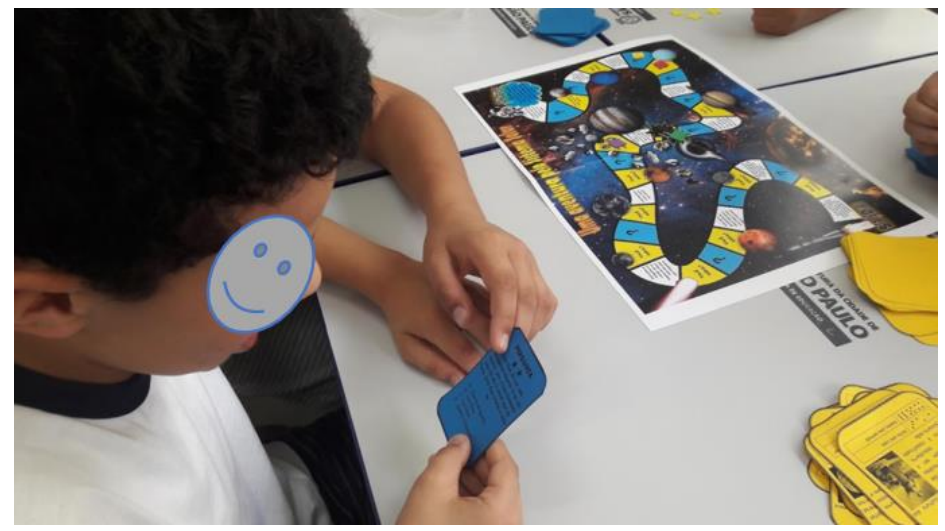

Figura 37 - Estudante lendo cartas do jogo

Logo no início da partida alguns grupos não sabiam exatamente onde posicionar os pinos. A professora explicou aos alunos que deveriam todos posicionarse em cima da palavra "saída". Definiram a ordem dos jogadores e iniciaram a partida. Os alunos mostravam-se motivados para realizar a atividade, falavam alto. Ao caírem na casa "pergunta" ficavam ansiosos e riam bastante. Ficavam entusiasmados ao acertarem e ainda "ganharem a estrela", ficavam constantemente contando a quantidade de estrelas que tinham coletado.

A professora notou que algumas cartas do "você sabia?" ficaram longas para a leitura dos estudantes, entretanto eles gostaram de ler os cartões para descobrir novas informações. No geral, o jogo teve uma duração de 30 a 40 minutos. Foi um tempo razoável, pois os alunos não ficaram cansados ou entediados com a atividade. Dois grupos terminaram num prazo mais curto, então puderam realizar uma nova partida. Para dois grupos faltaram estrelas, e para improvisar, a professora sugeriu que os alunos fossem desenhando em um papel a quantidade de estrelas faltantes. Ao final do jogo, a professora estimulou os alunos a contarem suas impressões sobre o jogo e dar sua opinião sobre ele.

O aluno 5 falou "eu aprendi um monte de coisa, mas eu já sabia várias, isso fez eu ganhar estrelas e quase ganhar no grupo". O aluno 14 explicou "Olha, eu gostei do jogo, ele é bonito e maior do que o jogo do Sol que você trouxe. A gente viajou pelo Sistema Solar e eu caí no buraco negro, mas eu tive sorte porque saí dele rápido, mas isso é no jogo né professora, porque se a minha nave caísse nele eu não saía mais (rindo)." A professora concordou com o estudante e deu a palavra ao aluno 9, "eu adorei o jogo, porque a gente aprende um monte de coisa", a professora perguntou ao aluno "o que você aprendeu? Conta pra gente", o aluno responde "Eu aprendi que 
a Mancha Vermelha de Júpiter é uma tempestade, e que Mercúrio tem o ano menor". A professora perguntou se mais alguém queria contar o que aprendeu no jogo, o aluno 28 disse "Eu sei! Eu aprendi sobre Marte, que ele tem uma montanha muito, mais muito alta mesmo. Chama Monte Olimpo e ele é maior que o Everest, três vezes maior que ele". Os alunos ainda sugeriram à professora para jogarem de novo. E assim, ela combinou com a turma que mais no final da semana poderiam jogar novamente.

\subsection{Aula 13 - Avaliação: O que eu aprendi?}

Esta foi a última aula proposta aos estudantes. Na verdade, não foi exatamente uma aula, e sim um momento de reflexão proposto aos estudantes sobre o que aprenderam durante este percurso realizado nos estudos dos Sistema Solar.

Inicialmente foi devolvido aos alunos o desenho feito por eles no início da Sequência Didática e eles foram orientados a observar o que desenharam e o que modificariam em seus desenhos depois do que aprenderam.

Este foi um momento muito interessante, pois os estudantes ficaram surpresos com os desenhos feitos. Vários estudantes citaram que não se lembravam do desenho e que se o fizessem hoje desenhariam bem diferente. $O$ aluno 7 disse "eu fiz Saturno, mas achava que estava desenhando Júpiter", outro aluno comentou "Eu fiz a Terra maior que o Sol'. O aluno 19 disse que escreveu o nome de Júpiter e Saturno errado. A professora permitiu que os alunos pudessem compartilhar seus desenhos com os demais colegas, comentando o que mudariam ou o que tinham feito correto antes da SD iniciar. Após cerca de vinte minutos a professora reuniu os estudantes e perguntou se mais alguém gostaria de compartilhar partes do desenho que eles fariam diferente. No geral os estudantes não queriam expor seus "erros", e a professora procurou tranquiliza-los dizendo que estavam todos aprendendo e que o importante naquele momento era eles conseguirem perceber o quanto tinham aprendido. $O$ aluno 12 disse que desenhou a Terra errado, com cores que não existem. A professora perguntou: "E hoje, depois dos nossos estudos, você conseguiria fazer um desenho para demonstrar o que você sabe?" o estudante concordou. Então a professora propôs à turma que eles fizessem o desenho novamente, mas agora, incluindo tudo o que aprenderam com as aulas da SD. Os alunos então receberam uma nova folha sulfite e iniciaram seus desenhos. 


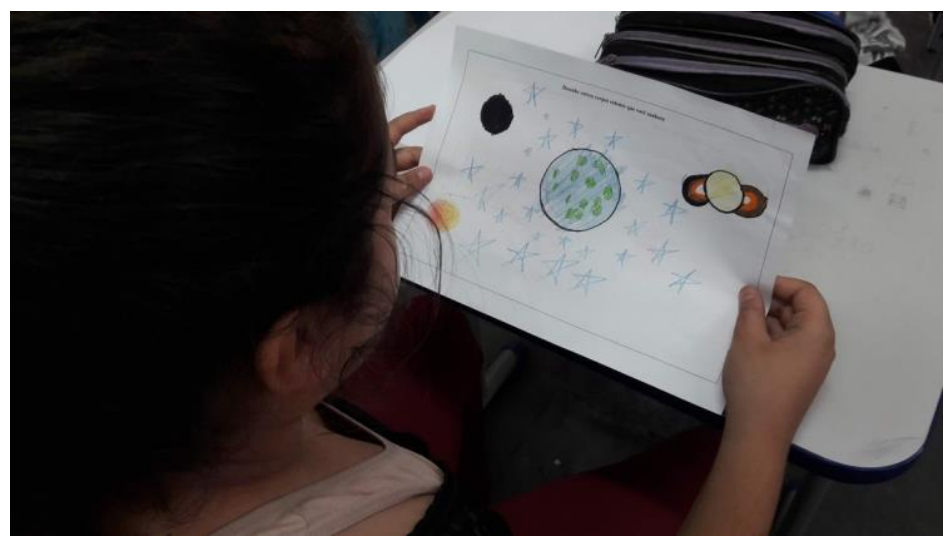

Figura 38 - Aluna analisando o desenho feito no início da SD

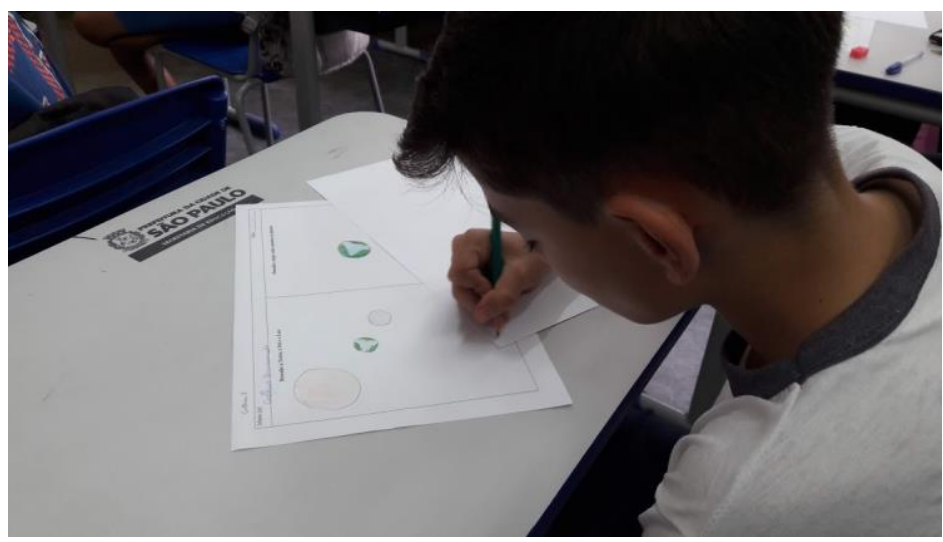

Figura 39 - Aluno confeccionando seu novo desenho após a participação na SD

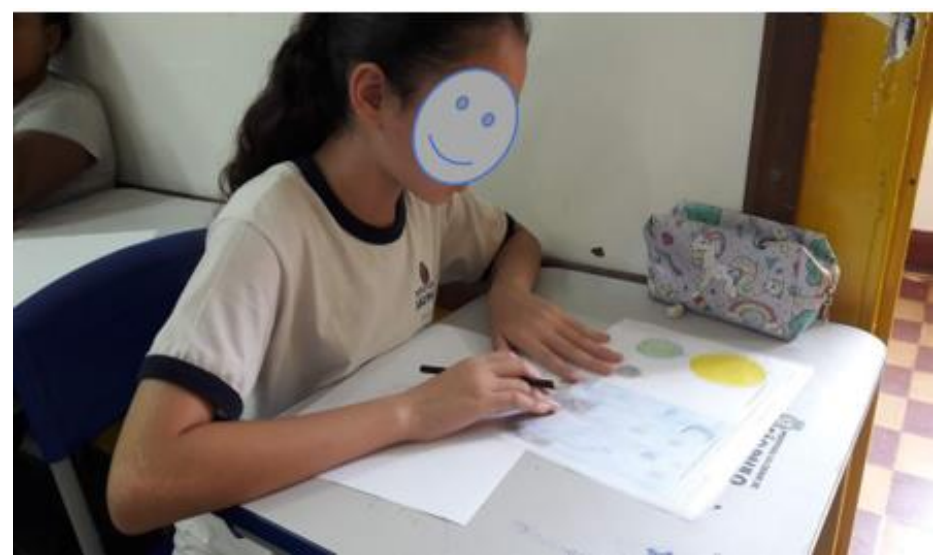

Figura 40 - Aluna analisando o desenho feito antes de iniciar a SD

Ao final puderam observar o quanto aprenderam comparando seus dois desenhos. A professora ainda pediu que os alunos contassem o que fizeram de diferente em seus desenhos. O aluno 15 explicou que "eu desenhei a Terra, o Sol e a Lua do mesmo tamanho, e agora eu corrigi, porque o Sol é muito maior e a Terra é bem pequena e a Lua ainda menor"; o aluno 2 disse "eu desenhei os planetas em ordem errada"; o aluno 11 falou "minha Terra parece um ovo e eu escrevi tudo errado (se referindo aos nomes dos planetas)"; o aluno 13 disse "eu fiz a Terra muito grande comparado ao Sol"; o aluno 21 explicou "eu desenhei a Terra e a Lua do mesmo 
tamanho, e agora eu já sei que a Lua e menor"; o aluno 19 explicou "eu fiz a Terra e todos os continentes juntos, grudados, e não é assim que a Terra é"; o aluno 25 disse "eu fiz a Lua maior que a Terra"; o aluno 5 ressaltou "eu desenhei os planetas nas cores erradas"; o aluno 10 comentou "eu fiz o Sol do tamanho da Terra e fiz Saturno e Marte iguais".

A professora elogiou a participação dos alunos, e disse que eles aprenderam bastante e que ela estava muito contente por isso. Aproveitou o momento e recordou que na primeira aula eles também responderam a um questionário. Ela explicou que iria entregar a eles o mesmo questionário, só que em branco, para eles responderem novamente, escrevendo o que já sabiam e que tinham aprendido. A professora tranquilizou a turma, explicando que esta era uma atividade diagnóstica apenas para a professora saber o que os alunos aprenderam. Os alunos demoraram cerca de 20 a 30 minutos para responder e assim foi finalizada a sequência de atividades sobre 0 Sistema Solar.

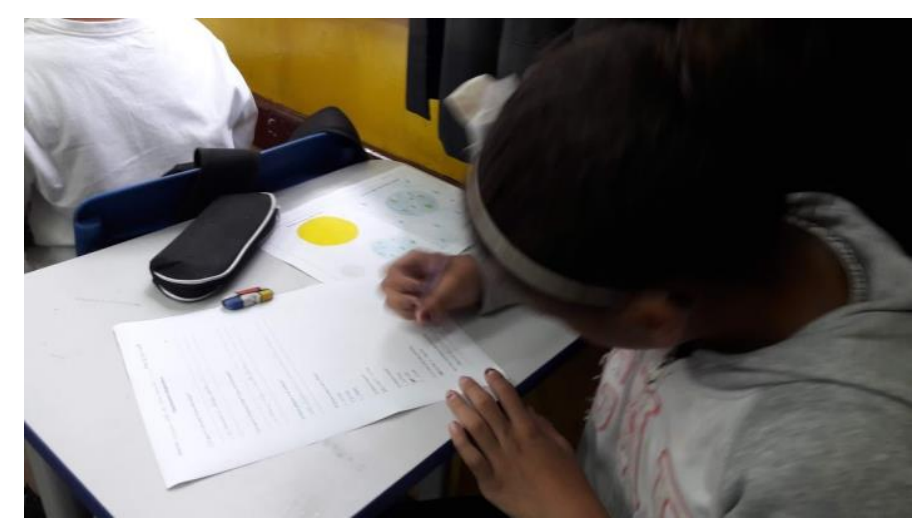

Figura 41 - Aluna respondendo ao questionário final 


\section{Capítulo 5 - Resultados da SD sobre o Sistema Solar}

Por meio da aplicação da SD foi possível coletar vários dados, expostos a seguir. Analisaram-se as informações obtidas de acordo com as atividades diagnósticas para o levantamento de conhecimentos prévios dos estudantes antes e após a aplicação da SD, e também a coleta de dados encontrada pelos alunos nas lições de casa e pesquisas.

\section{1 - Questionário diagnóstico inicial}

A análise do questionário apresentado refere-se à atividade inicial que foi realizada antes da aplicação da SD. Neste questionário diagnóstico participaram 28 estudantes. As respostas foram classificadas como: correta, incorreta, parcial e não respondeu.

Na primeira questão "O que é o Universo? Como ele surgiu?", procurou-se subdividir as respostas em 1a e 1b. Considerou-se resposta correta para a questão $1 a$, quando os alunos descreveram o Universo como o espaço em que existem todos astros, como estrelas, planetas, galáxias, satélites, etc. respeitando a elaboração do pensamento do aluno; considerou-se ainda como resposta parcial quando os estudantes se referiram ao Universo, citando exemplos de alguns astros que o compõe, como a Lua, os planetas, os cometas, o Sol, etc. Nesta questão, apenas dois alunos, o que corresponde a $7,1 \%$ responderam dentro do parâmetro considerado correto; dezenove alunos responderam de forma parcial, o que corresponde a 67,9\%, três alunos (10,7\%) responderam errado e quatro alunos (14,3\%) não souberam responder. As figuras 42 a 47 trazem algumas respostas:

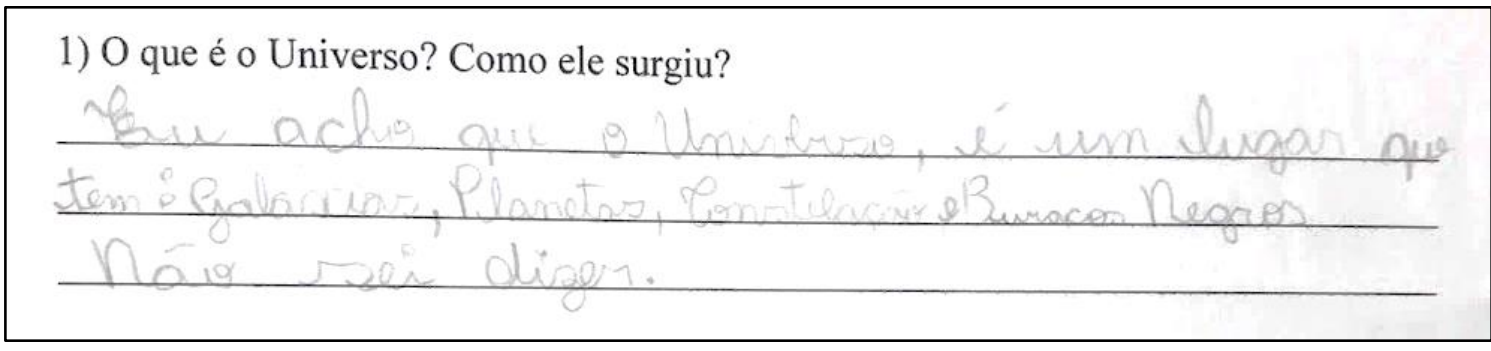

Figura 42 - Resposta considerada correta para a questão $1 a$. 
1) O que é o Universo? Como ele surgiu?

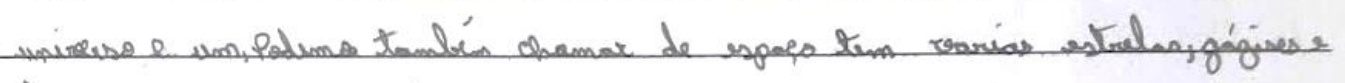

Plantar, ou ocho que unvibus surgir cem gófes.

Figura 43 - Resposta considerada correta para a questão $1 a$.

1) O que é o Universo? Como ele surgiu?

- munrerda é yma cassa que dennTra eristem mitas cavar porerempLa a nAra munta, Q Sól. En náa rei de ande vera a unu verbs

Figura 44 - Resposta considerada parcial para a questão 1 a.

1) O que é o Universo? Como ele surgiu?

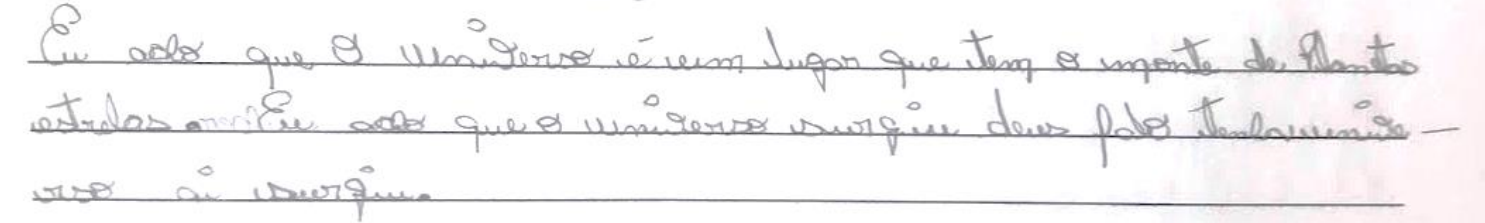

Figura 45 - Resposta considerada parcial para a questão $1 a$.

1) O que é o Universo? Como ele surgiu?

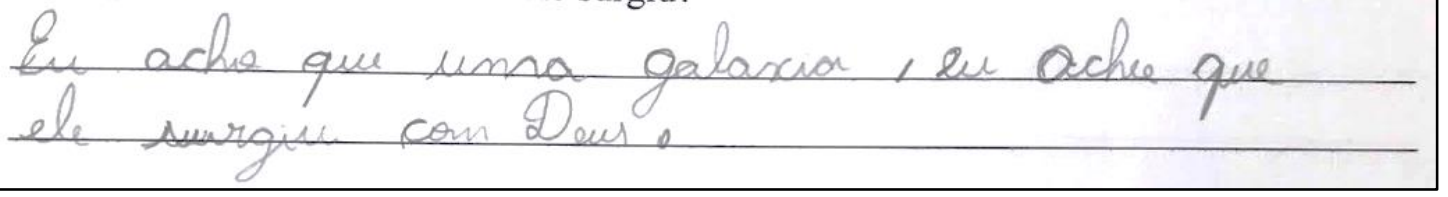

Figura 46 - Resposta considerada incorreta para a questão 1 a.

1) O que é o Universo? Como ele surgiu?

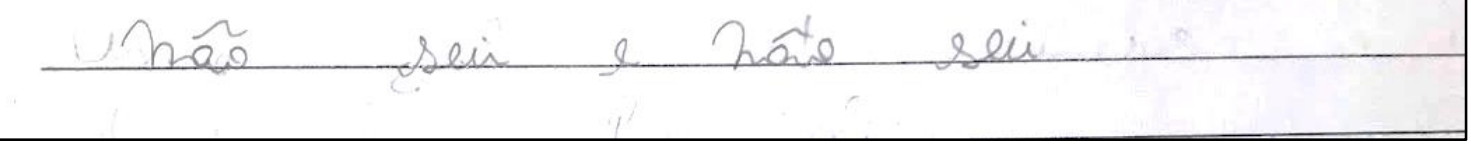

Figura 47 - Resposta considerada como não respondeu na questão $1 a$.

A questão $1 b$ - "Como ele surgiu?" foi mais complexa para os estudantes responderem. A resposta para o surgimento do Universo foi considerada correta quando o estudante citou a teoria do Big Bang (sem descrevê-la); foi considerada resposta parcial quando o estudante mencionou que o surgimento foi a partir de uma explosão ou algo semelhante, (que apesar de não ser adequada, se assemelha a uma forma mais popular para explicar o Big Bang). Nesta questão nenhum estudante 
acertou $(0 \%)$, e apenas uma resposta foi considerada parcial $(3,6 \%)$. Seis respostas foram consideradas erradas $(21,4 \%)$ e vinte e uma foram consideradas não respondidas (75\%). As figuras 48 a 50 trazem alguns exemplos de respostas obtidas:

1) O que é o Universo? Como ele surgiu?

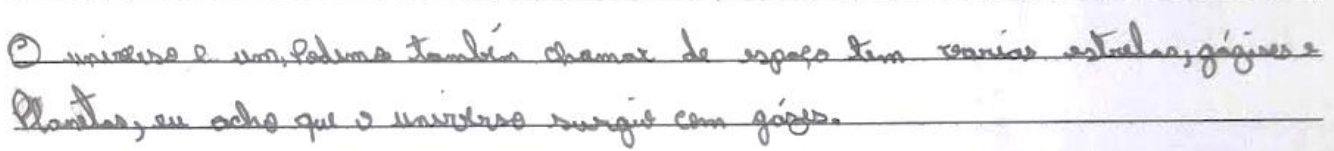

Figura 48 - Resposta considerada como parcial na questão $1 b$.

1) O que é o Universo? Como ele surgiu?

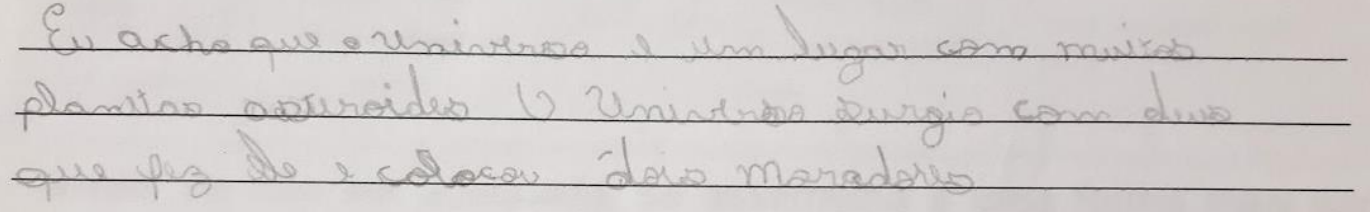

Figura 49 - Resposta considerada como incorreta na questão $1 b$.

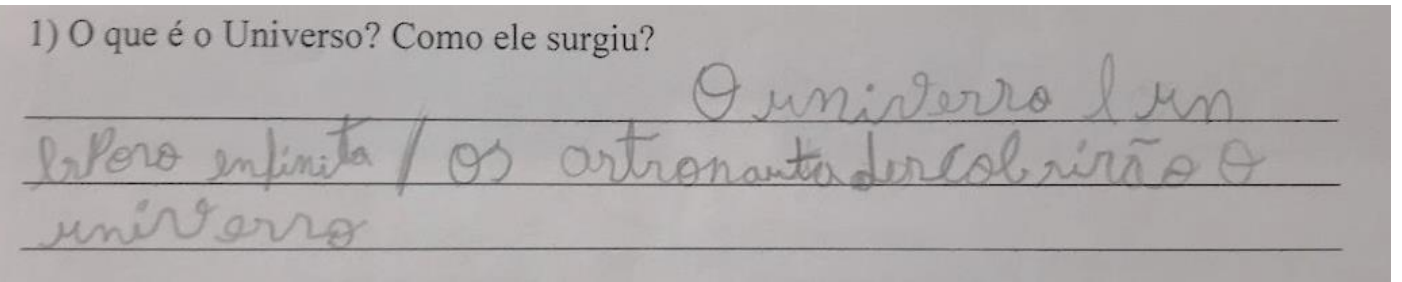

Figura 50 - Resposta considerada incorreta na questão $1 \mathrm{~b}$.

De acordo com os resultados das respostas à primeira questão podemos observar que os estudantes não conseguem conceituar a imensidão do Universo, mas já são capazes de citar elementos que o compõe, como estrelas, planetas, e outros astros e mencionam também que o Universo é o espaço fora da Terra, grande, infinito, etc. Quando indagados sobre como o Universo surgiu, poucos alunos conseguiram construir uma resposta, a maioria preferiu escrever "não sei". Os poucos alunos que se arriscaram trouxeram concepções religiosas. Na figura 50 o aluno atribui o surgimento do Universo quando astronautas passam a ir ao espaço. Nenhum aluno citou a teoria do Big Bang para explicar a origem do Universo, entretanto um aluno (figura 48) citou o surgimento a partir de gases, o que pode indicar que ele já tenha tido uma experiência anterior com este assunto. 
Na questão 2 se perguntava: “O que é o Sistema Solar? Como ele é formado?”, e para considerar correta a resposta, esperava-se que o estudante citasse que o Sistema Solar é o local composto pelo Sol e os planetas girando ao seu redor, além de outros astros como asteroides, cometas, satélites naturais, etc. Seria considerada como resposta parcial se o estudante conseguisse citar alguns astros que o formam. Nesta questão nenhum aluno conseguiu descrever o que é o Sistema Solar com a riqueza de elementos que esperávamos; oito alunos $(28,6 \%)$ conseguiram citar nome de alguns planetas girando ao redor do Sol, mas não mencionaram outros corpos celestes como os cometas, asteroides, planetas anões e satélites como pertencentes ao sistema; doze alunos (42,9\%) responderam de forma incorreta, e a maioria associou o nome Sistema Solar como se referindo a algo sobre o Sol, por levarem em conta o nome "solar"; em algumas respostas os estudantes explicam "deve ser sobre o Sol'; oito alunos $(28,6 \%)$ não souberam responder à questão. As figuras 51 a 55 apresenta-se algumas respostas dos estudantes:

2) O que é o Sistema Solar? Como ele é formado?

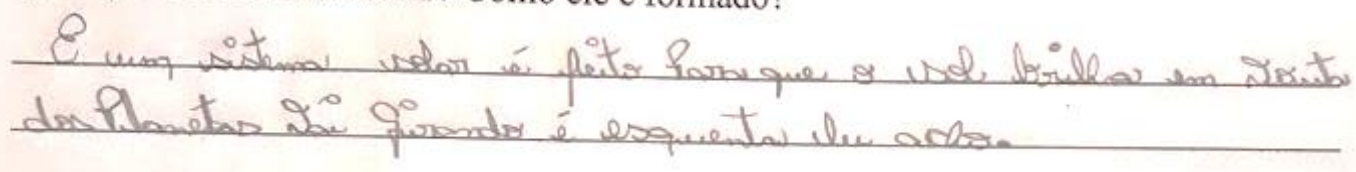

Figura 51 - Resposta considerada parcial

2) O que é o Sistema Solar? Como ele é formado?

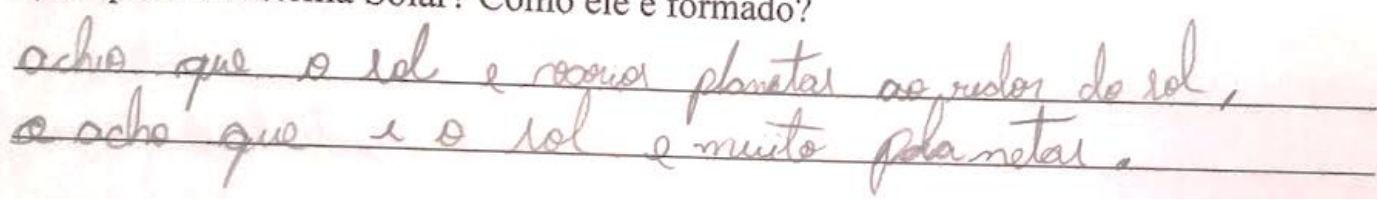

Figura 52 - Resposta considerada parcial

2) O que é o Sistema Solar? Como ele é formado?

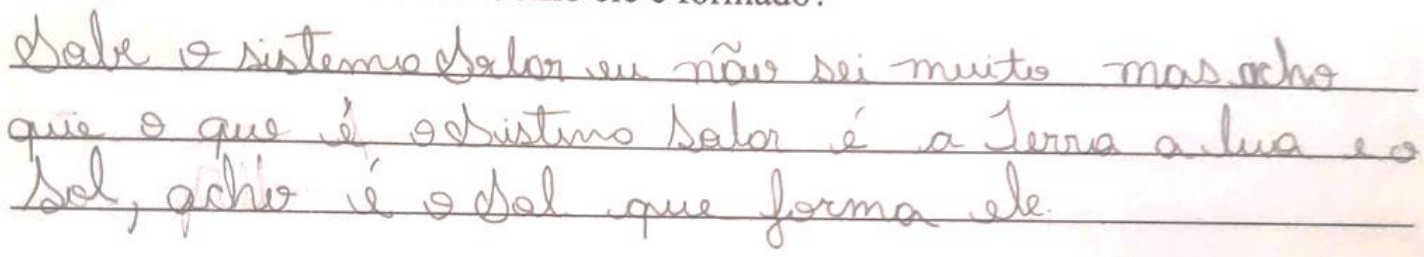

Figura 53 - Resposta considerada parcial

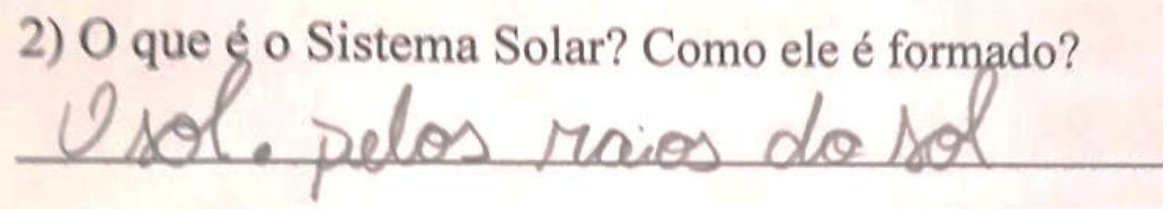

Figura 54 - Resposta considerada incorreta 


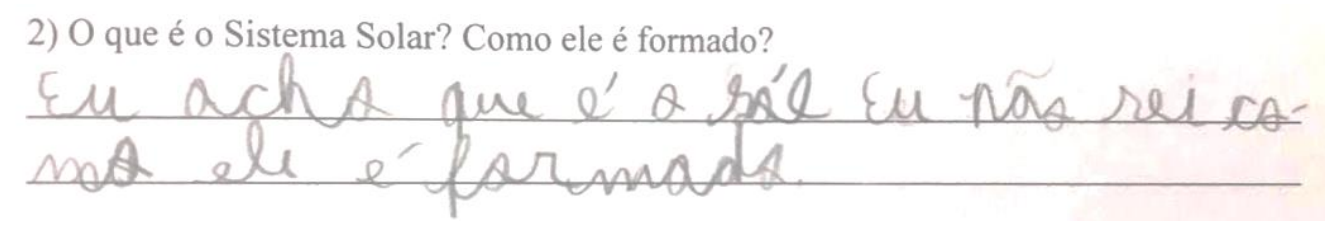

Figura 55 - Resposta considerada incorreta

A questão 3 "Quais planetas você conhece?" é uma pergunta aberta, pois o estudante poderia citar o nome de um planeta e acertaria a questão. Entretanto, com o objetivo de coleta de dados, classificamos as situações em que os estudantes citaram o nome de todos os planetas como questão correta, quando citaram o nome de alguns planetas a classificamos como parcial, e classificamos como incorreta quando os estudantes citaram o nome de planetas misturados com outros astros como o Sol, Lua, entre outros. A tabela 06 apresenta os resultados:

\begin{tabular}{|l|r|r|}
\hline \multicolumn{3}{|c|}{ Questão 3 } \\
\hline Correta & 1 & $3,6 \%$ \\
\hline Parcial & 13 & $46,4 \%$ \\
\hline Incorreta & 14 & $50,0 \%$ \\
\hline Não respondeu & 0 & $0 \%$ \\
\hline Total & 28 & $100 \%$ \\
\hline
\end{tabular}

Tabela 6 - Respostas dos estudantes na questão 3 do questionário diagnóstico.

De acordo com o resultado apresentado na tabela 6 , apenas um estudante conseguiu citar todos os planetas do Sistema Solar (Figura 56).

3) Quais planetas você conhece?

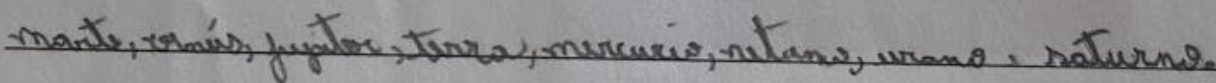

Figura 56 - Resposta considerada correta

Foi possível observar que $46,4 \%$ dos alunos já conseguem nomear alguns planetas, diferenciando-os de estrelas, satélites naturais, etc. As figuras 57 e 58 ilustram algumas respostas coletadas.

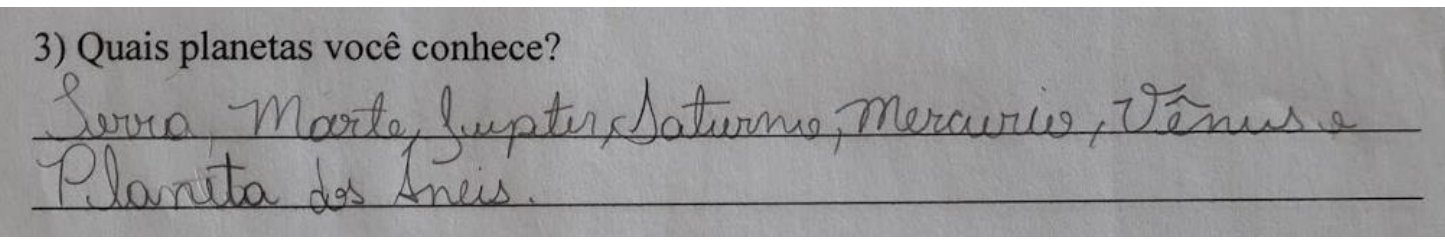

Figura 57 - Resposta considerada parcial 
3) Quais planetas você conhece?

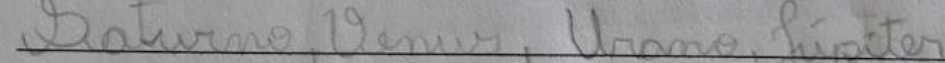

Figura 58 - Resposta considerada parcial

Nas respostas apresentadas nos chamam a atenção o fato de que alguns estudantes citam "o planeta dos anéis" e "Saturno" como planetas distintos.

As respostas consideradas incorretas chegaram a $50 \%$, quando os alunos fizeram menção a alguns planetas, mas acrescentaram outros corpos celestes não pertencentes a esta classificação, citando a Via Láctea, o Sol, Plutão (planeta-anão) e a Lua. Entretanto, poderiam ser consideradas como respostas parciais, pois apresentam um conhecimento prévio dos estudantes acerca do assunto que será estudado. Mas, de acordo com nossa correção inicial serão classificadas desta maneira. As figuras 59 e 60 trazem algumas respostas:

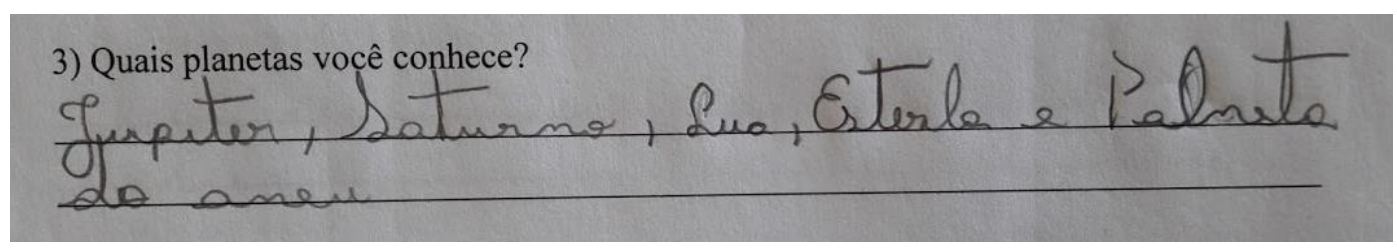

Figura 59 - Resposta considerada incorreta

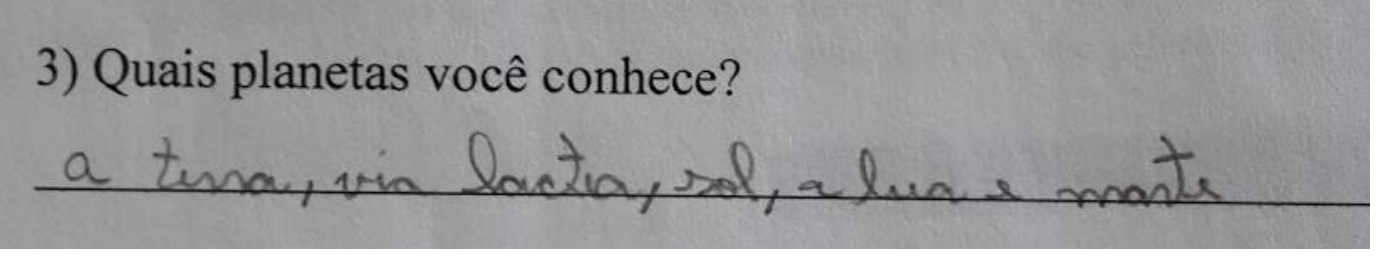

Figura 60 - Resposta considerada incorreta

A questão 4 "Quem é maior que a Terra?", apresentava aos estudantes três alternativas: a Lua; o Sol e Marte. Acertaram a resposta, assinalando o Sol como maior do que a Terra, treze estudantes $(46,4 \%)$, e quinze $(53,6 \%)$ erraram a resposta. Quando divididos os erros pelas escolhas pode-se observar que Marte é o principal escolhido como candidato maior do que a Terra, contando com $40 \%$ das escolhas, contra $26,7 \%$ dos estudantes que optaram pelo Sol e Lua. Observe a tabela 7 com os resultados mais detalhados: 


\begin{tabular}{|l|r|r|}
\hline \multicolumn{3}{|c|}{ Questão 4} \\
Quem é maior que a Terra? \\
\hline Lua & 1 & $6,7 \%$ \\
\hline Sol e Lua & 4 & $26,7 \%$ \\
\hline Sol, Lua e Marte & 1 & $6,7 \%$ \\
\hline Marte & 6 & $40,0 \%$ \\
\hline Sol e Marte & 3 & $20,0 \%$ \\
\hline Total & 15 & $100,0 \%$ \\
\hline
\end{tabular}

Tabela 7 - Respostas incorretas dos estudantes na questão 4 do questionário diagnóstico.

Estas escolhas revelam várias informações, entre elas o desconhecimento dos estudantes ao interpretar o tamanho dos astros, e conseguir realizar a classificação deles em planetas, estrelas e/ou satélites. Isso nos indica que a Sequência Didática deve trazer aos estudantes essa experiência de refletir sobre os tamanhos bem como sua proporção.

Em resposta à questão 5 os estudantes devem responder "Quem é maior?", tendo como alternativa apenas o Sol e a Lua. Os estudantes apresentam um melhor desempenho nesta questão, pois $78,6 \%$ escolheu o Sol como o astro maior, contra $21,4 \%$ que optou a Lua, conforme mostra a tabela 08.

\begin{tabular}{|l|r|r|}
\hline \multicolumn{3}{|c|}{ Questão 5 - Quem é maior? } \\
Sol & 22 & $78,6 \%$ \\
Lua & 6 & $21,4 \%$ \\
Total & 28 & $100 \%$ \\
\hline
\end{tabular}

Tabela 8 - Respostas dos estudantes na questão 5 do questionário diagnóstico.

A questão 6, pergunta sobre os tamanhos "Quem é maior?", mas amplia as opções para Terra, Sol e Lua. Nestas opções, $57,1 \%$ dos estudantes acertam a resposta, escolhendo o Sol como alternativa, enquanto $36 \%$ escolheu a Terra e 7,1\% optou pela Lua.

Na questão 7 os alunos são indagados "A Terra está mais próxima do Sol ou da Lua?", dezenove alunos, representados por 67,9\% acertaram a resposta escolhendo a Lua como o astro mais próximo da Terra, enquanto nove estudantes optaram por escolher o Sol, representando $32,1 \%$. 
A questão 8 indagava aos alunos sobre "Como ocorrem os dias e as noites?". Podemos observar na tabela 9, que apenas um estudante conseguiu explicar que os dias e as noites ocorrem devido ao movimento de rotação (sem usar esse termo), pois conforme a Terra gira uma parte do planeta é iluminada acarretando o dia, e progressivamente uma parte vai deixando de ser iluminada, caracterizando a noite, conforme mostrado na figura 61 . Os estudantes classificados como resposta parcial responderam que o dia e a noite ocorrem porque a Terra gira, mas não conseguiram explicar com detalhes como o fenômeno ocorre.

\begin{tabular}{|l|r|r|}
\hline \multicolumn{3}{|c|}{ Questão 8 } \\
Correta & 1 & $3,6 \%$ \\
Parcial & 11 & $39,3 \%$ \\
Incorreta & 15 & $53,6 \%$ \\
Não respondeu & 1 & $3,6 \%$ \\
Total & 28 & $100 \%$ \\
\hline
\end{tabular}

Tabela 9 - Respostas dos estudantes na questão 8 do questionário diagnóstico.

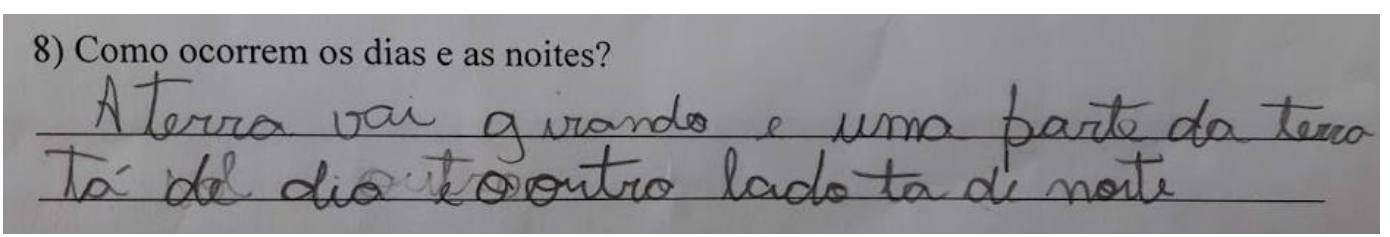

Figura 61 - Resposta considerada correta

Mesmo o estudante não tendo citado o movimento de rotação para a ocorrência dos dias e das noites, ele demonstra que compreende que ao girar a Terra vai sendo iluminada em algumas regiões, enquanto outras vão deixando de ser iluminadas.

$\mathrm{Na}$ resposta da Figura 62, considerada como parcial, é possível notar que o estudante afirma que a Terra gira, mas fica confuso ao explicar como esse processo ocorre, e acaba por afirmar que Sol e Lua estão parados e por isso o fenômeno ocorre.

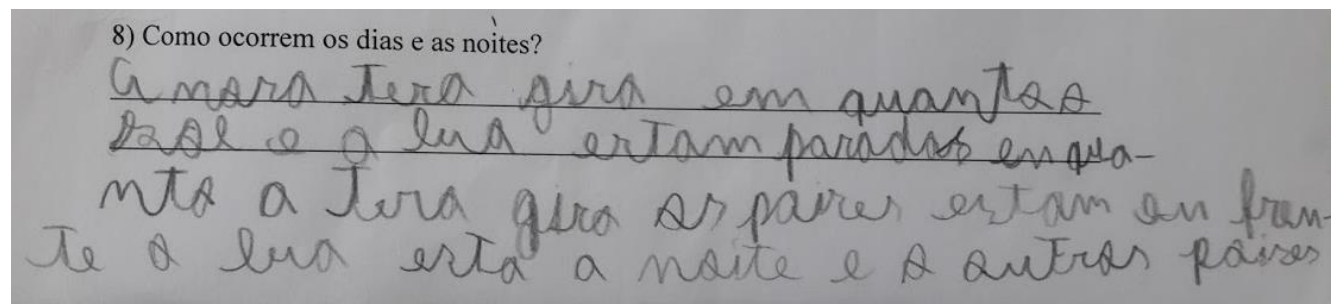

Figura 62 - Resposta considerada parcial 
Na resposta da Figura 63, também considerada parcial, o aluno já sabe que para ter dia e noite a Terra precisa girar, entretanto faltou informações para compreendermos se de fato o aluno sabe como o processo funciona.

\section{8) Como ocorrem os dias e as noites?}

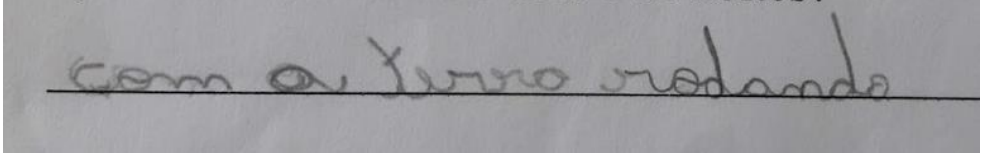

Figura 63 - Resposta considerada parcial

Nas figuras 64 a 67 apresentamos algumas respostas consideradas incorretas, de acordo com nossa análise. Percebe-se que os estudantes associam a ocorrência dos dias e noites com a aproximação dos astros Sol e Lua na Terra. Alguns até citam a palavra "girar" mas não atribuem esta característica à Terra.

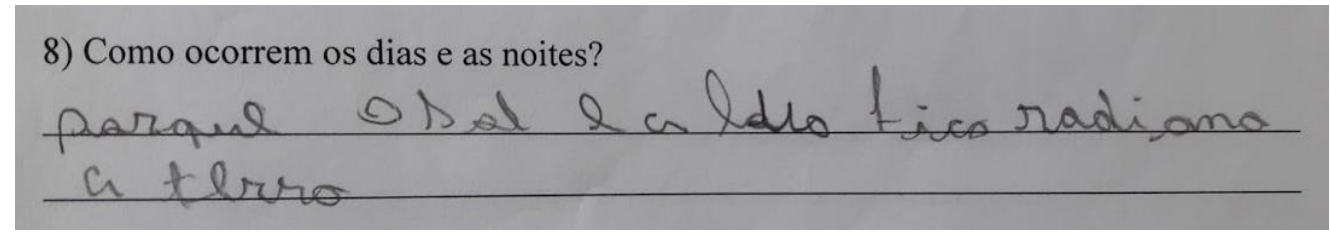

Figura 64 - Resposta considerada incorreta

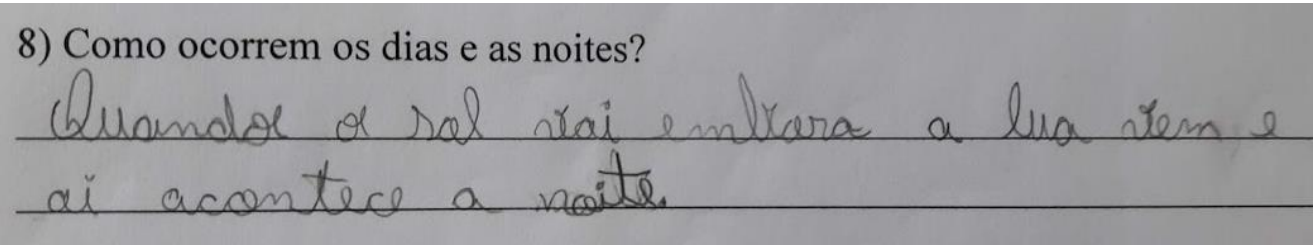

Figura 65 - Resposta considerada incorreta

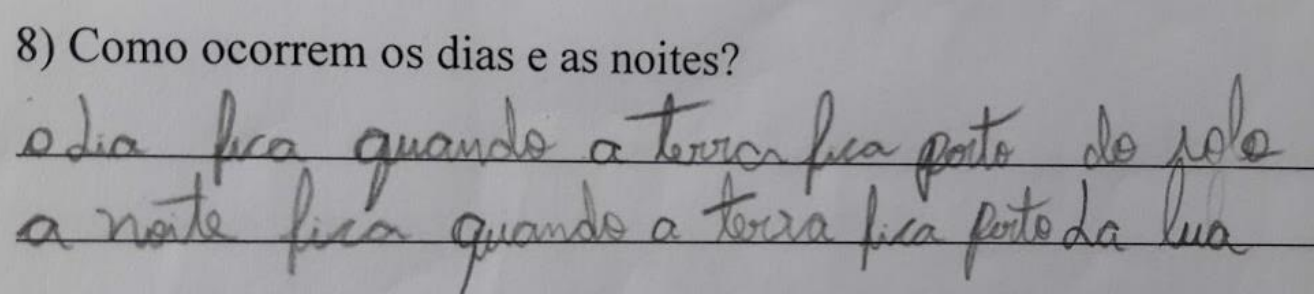

Figura 66 - Resposta considerada incorreta

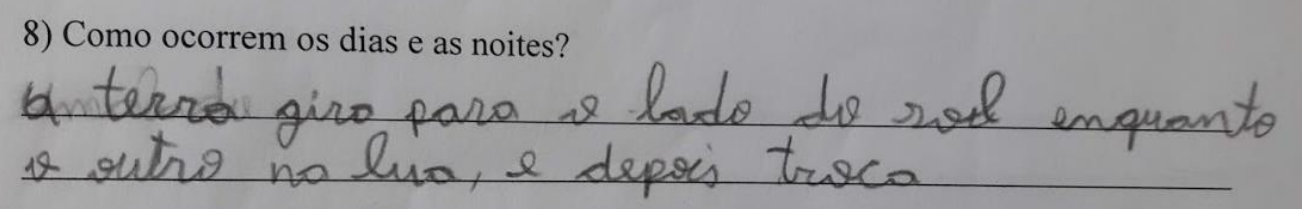

Figura 67 - Resposta considerada incorreta 
A análise dos dados obtidos será somada à segunda atividade diagnóstica que os estudantes realizaram antes da aplicação da SD, que é a confecção de desenhos.

5.2 - Desenhos produzidos na atividade diagnóstica inicial

Realizado o questionário, os alunos foram convidados a desenhar:

- A Terra, o Sol e a Lua;

- O local onde estão no planeta;

- Outros astros/corpos celestes que conhecem.

A professora ainda procurou incentivar os estudantes a colorirem seus desenhos e escrever legendas quando possível.

As figuras 68,69 e 70 trazem algumas imagens da representação do Sol, Terra e Lua:
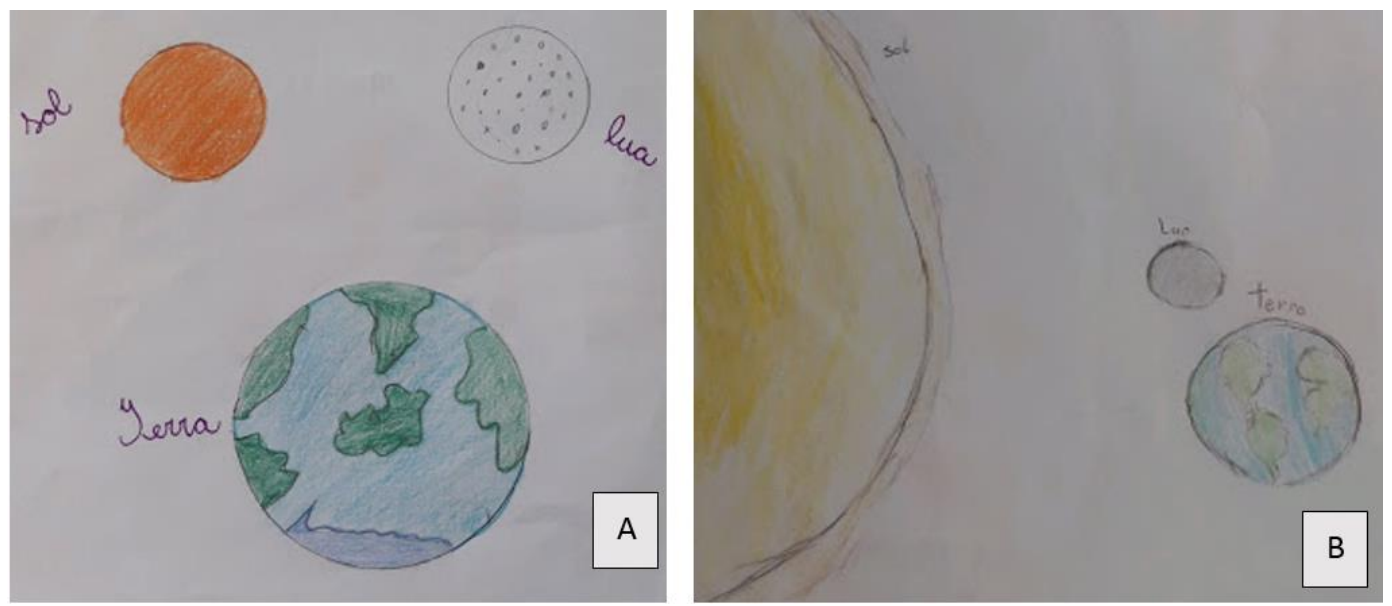

Figura 68 - Desenhos da Terra, Lua e Sol.
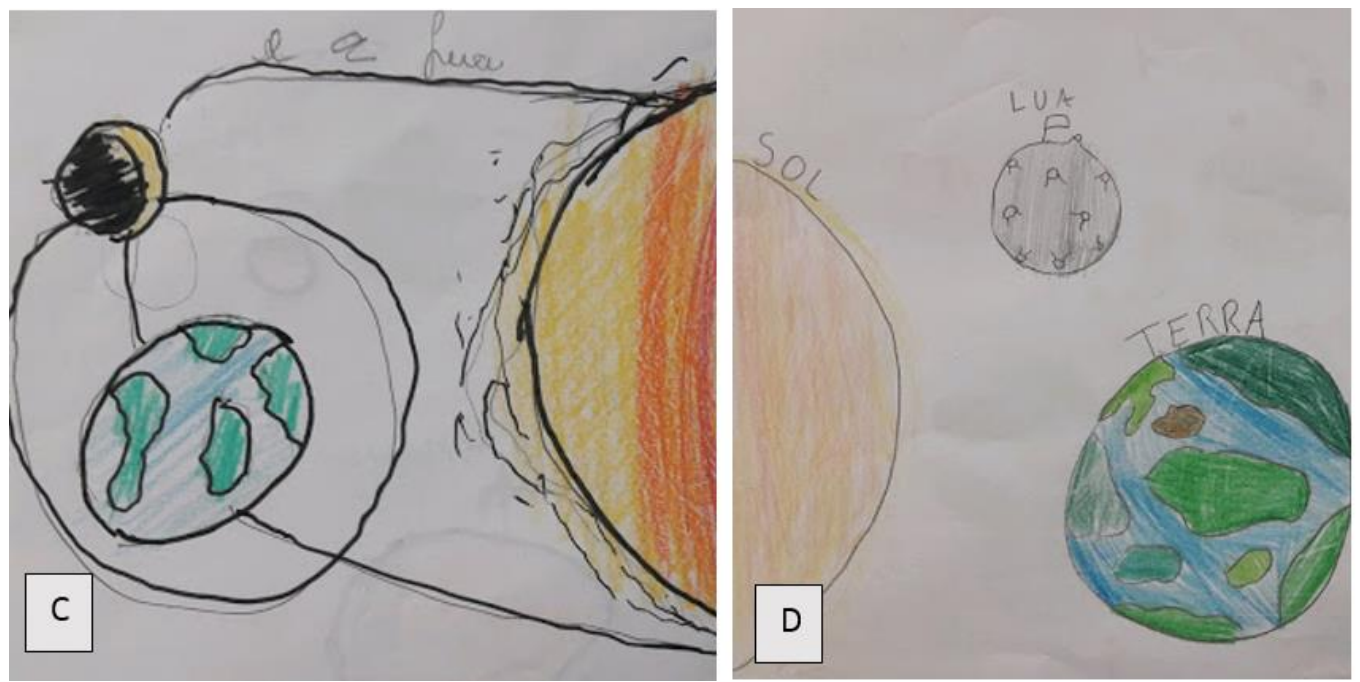

Figura 69 - Desenhos da Terra, Lua e Sol 

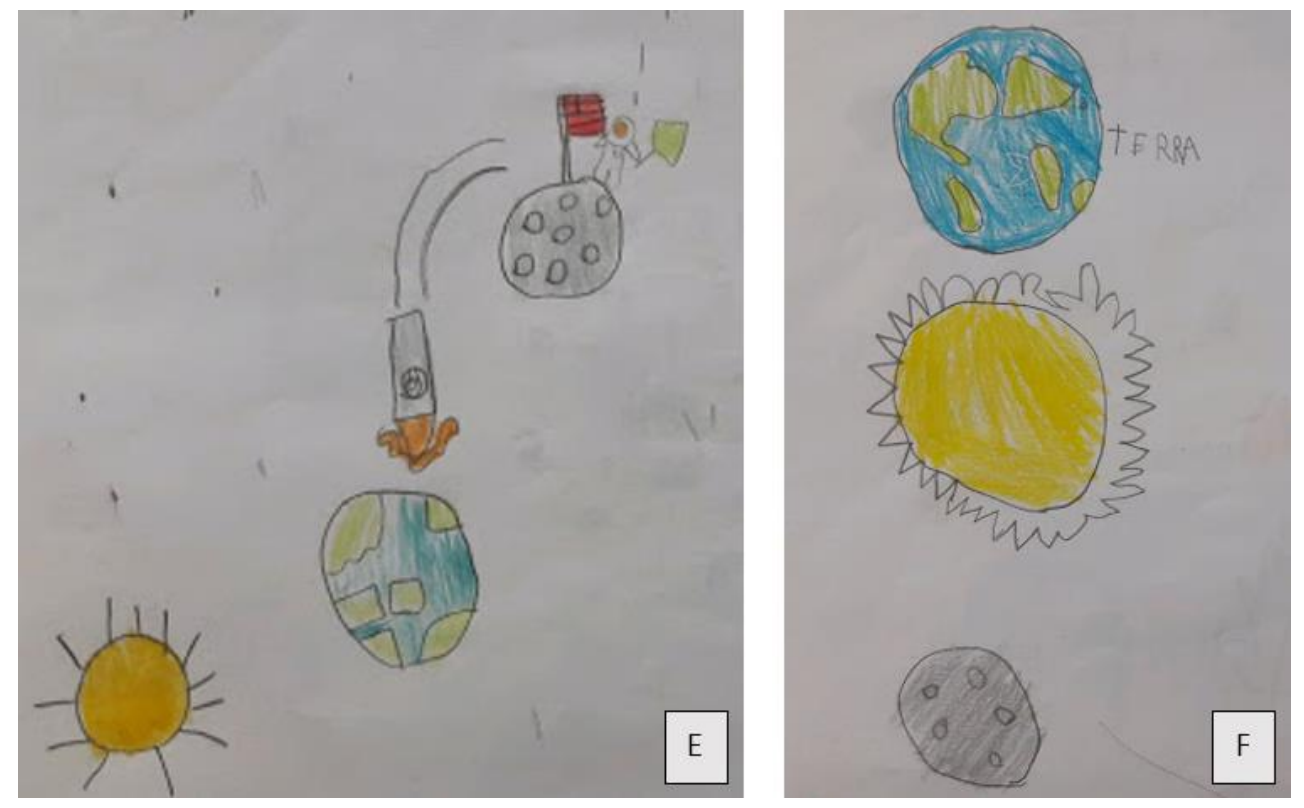

Figura 70 - Desenho da Terra, Lua e Sol

Pode-se observar que os alunos representaram o Sol de diversas maneiras; alguns colocaram raios e outros apenas o representaram como um círculo. Alguns já demonstraram saber que o Sol é maior que a Terra e a Lua, sendo assim o fizeram maior. Analisando a figura A é possível notar que o aluno desenhou a Terra maior que o Sol e a Lua, e na figura B foi o contrário, o estudante procurou deixar o Sol em destaque, desenhando uma parte dele na folha, para representar que era muito maior que a Terra e a Lua. Na figura $\mathrm{C}$ pode-se observar vários aspectos: o desenho das órbitas dos respectivos astros, e a Lua iluminada na direção que está apontada ao Sol; essa imagem está carregada de conhecimentos prévios do estudante acerca dos assuntos que a SD irá abordar, e também seu desenho se assemelha aos desenhos de enciclopédias ou livros didáticos, com os quais ele possivelmente já teve contato. $\mathrm{Na}$ figura $\mathrm{D}$ observamos que $\mathrm{o}$ aluno conhece a ida do homem à Lua e da representação da bandeira americana, sendo que o mesmo se observa na figura $E$. A figura $\mathrm{F}$ representou os astros praticamente do mesmo tamanho, com a Terra composta por continentes e oceanos e a Lua já com as crateras.

No segundo desenho os alunos foram convidados a desenhar o lugar onde estão no planeta, apareceram diversos desenhos, apresentados na Figura 71. 

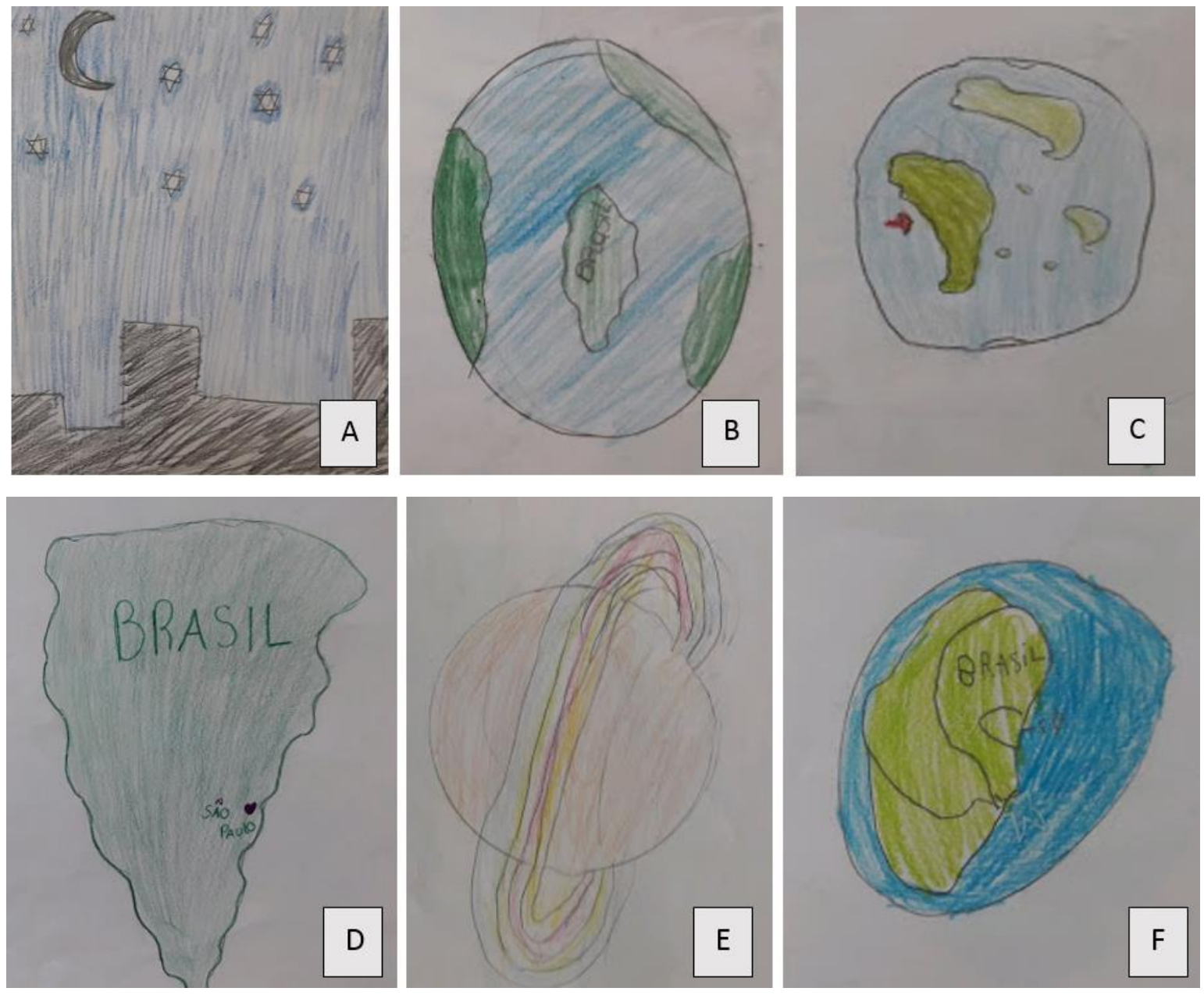

Figura 71 - Desenhos de locais onde os alunos "moram"

Os alunos escolheram diversas representações para mostrarem onde estamos no planeta. Na figura A por exemplo o estudante optou por desenhar uma paisagem noturna de algum local da Terra, uma cidade urbana, com prédios e estrelas. Na figura B, C e F nota-se a representação do planeta Terra, com continentes e oceanos e o Brasil sendo representado; alguns ainda sinalizaram com seta o local, o que demonstra que estes alunos já possuem uma compreensão geográfica e política da Terra, e possivelmente já tiveram o contato com representações da Terra por meio de mapas ou o globo terrestre. A figura D omite planeta Terra, mas mostra o mapa do país e a localização de São Paulo. E por fim, a representação E demonstra um planeta que se assemelha a Saturno. Pode-se interpretar que o estudante não compreendeu a consigna, ou que não sabia representar graficamente o planeta. Entretanto ele escolheu um planeta para representar sua morada. 
Por meio dos desenhos apresentados observa-se que a turma possui diversos conhecimentos, mostrando que a SD com a abordagem sociocultural é fundamental para desenvolver a aprendizagem da turma.

O último desenho solicitava que os alunos representassem outros astros que conheciam. As figuras 72 a 76 mostram algumas imagens selecionadas:
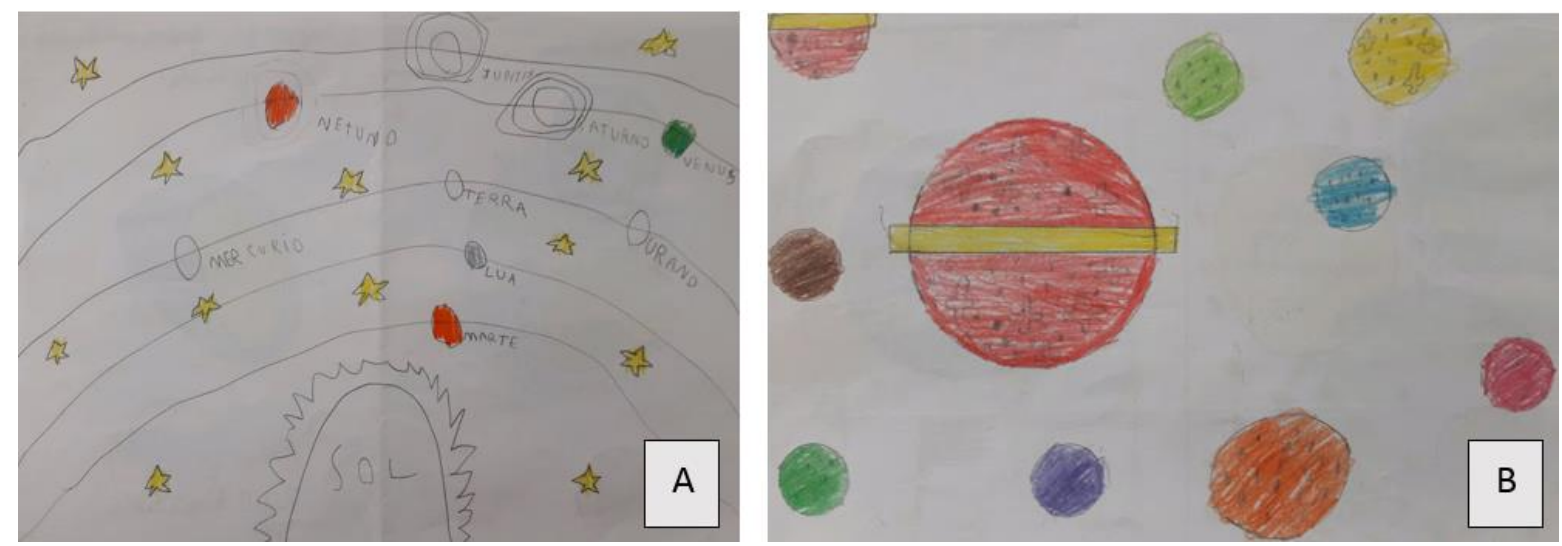

Figura 72 - Desenhos de outros corpos celestes
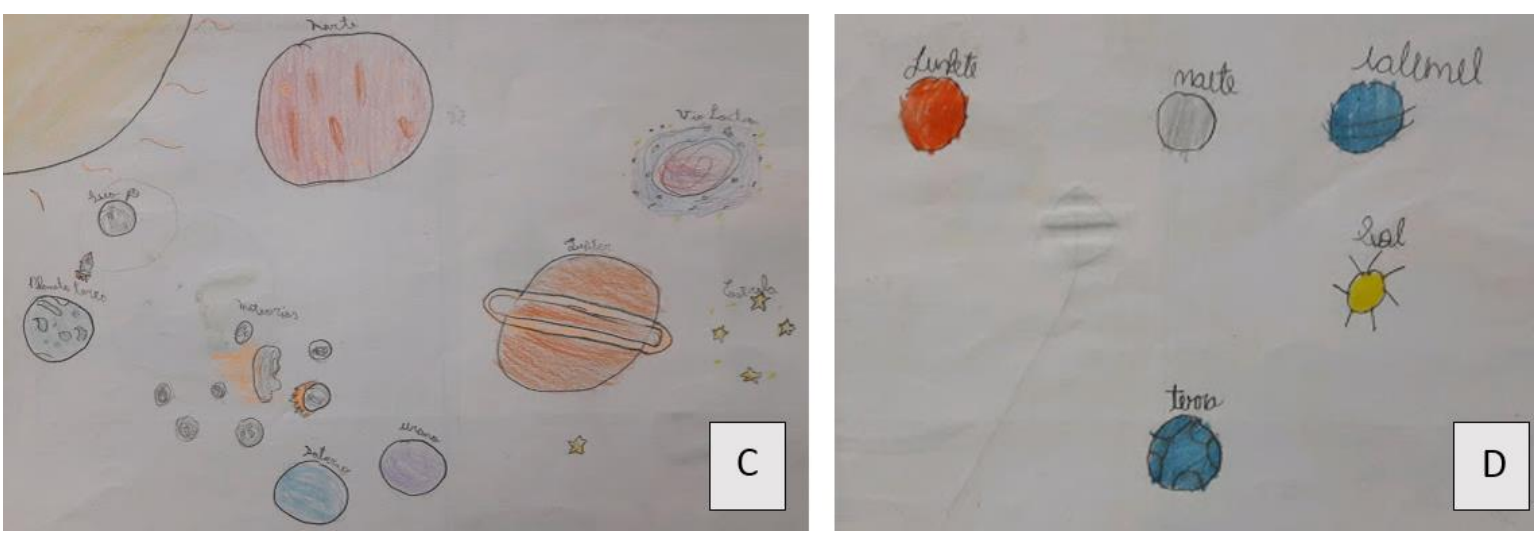

Figura 73 - Desenhos de outros corpos celestes
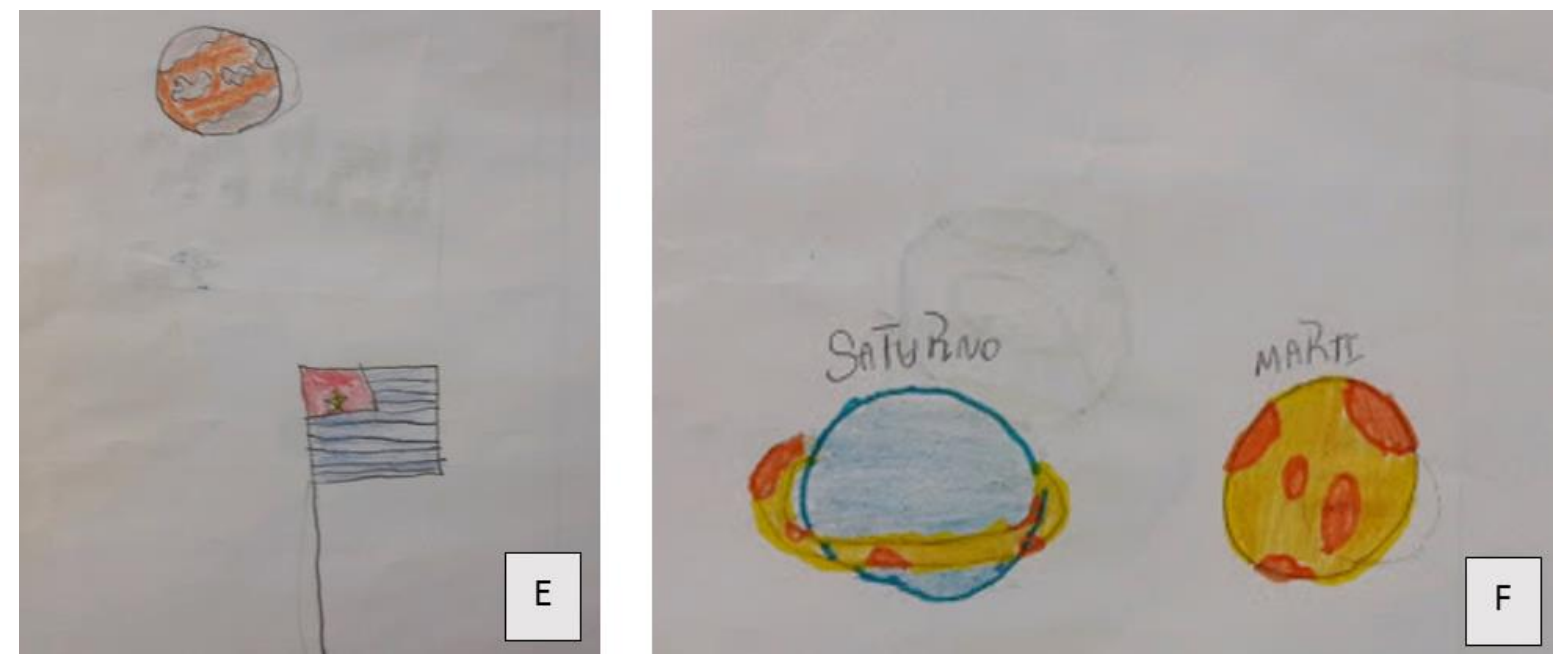

Figura 74 - Desenhos de outros corpos celestes 


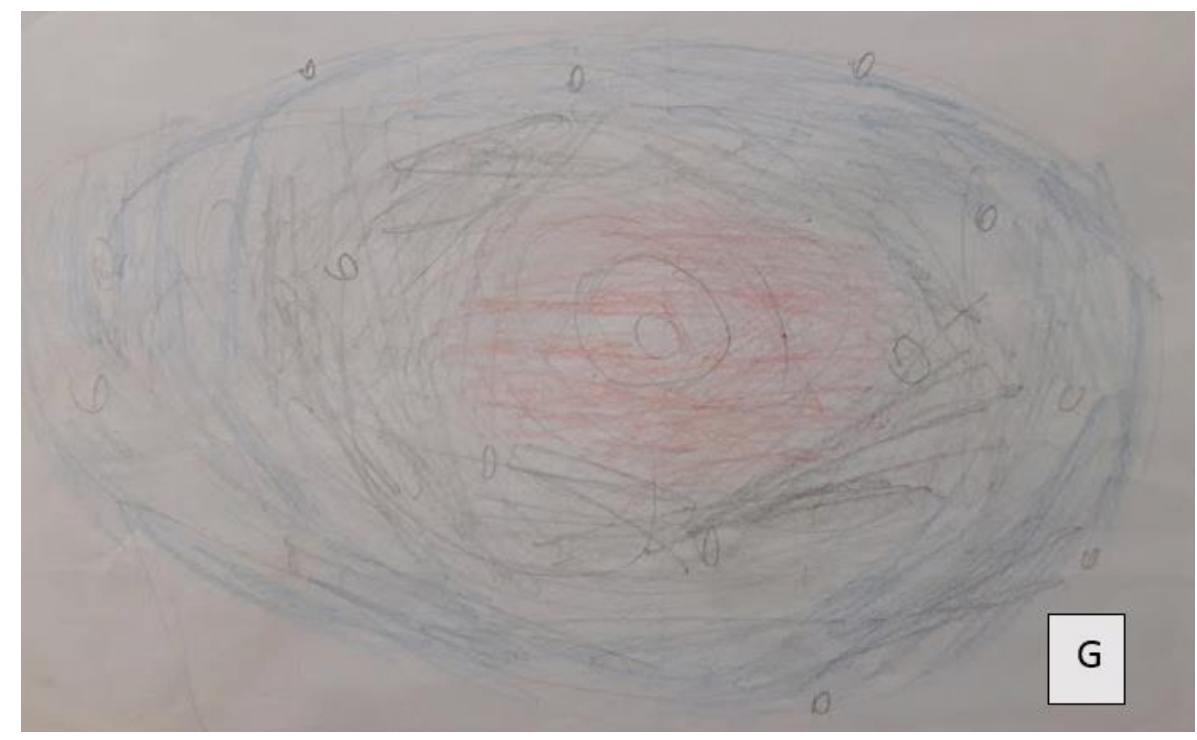

Figura 75 - Desenhos de outros corpos celestes

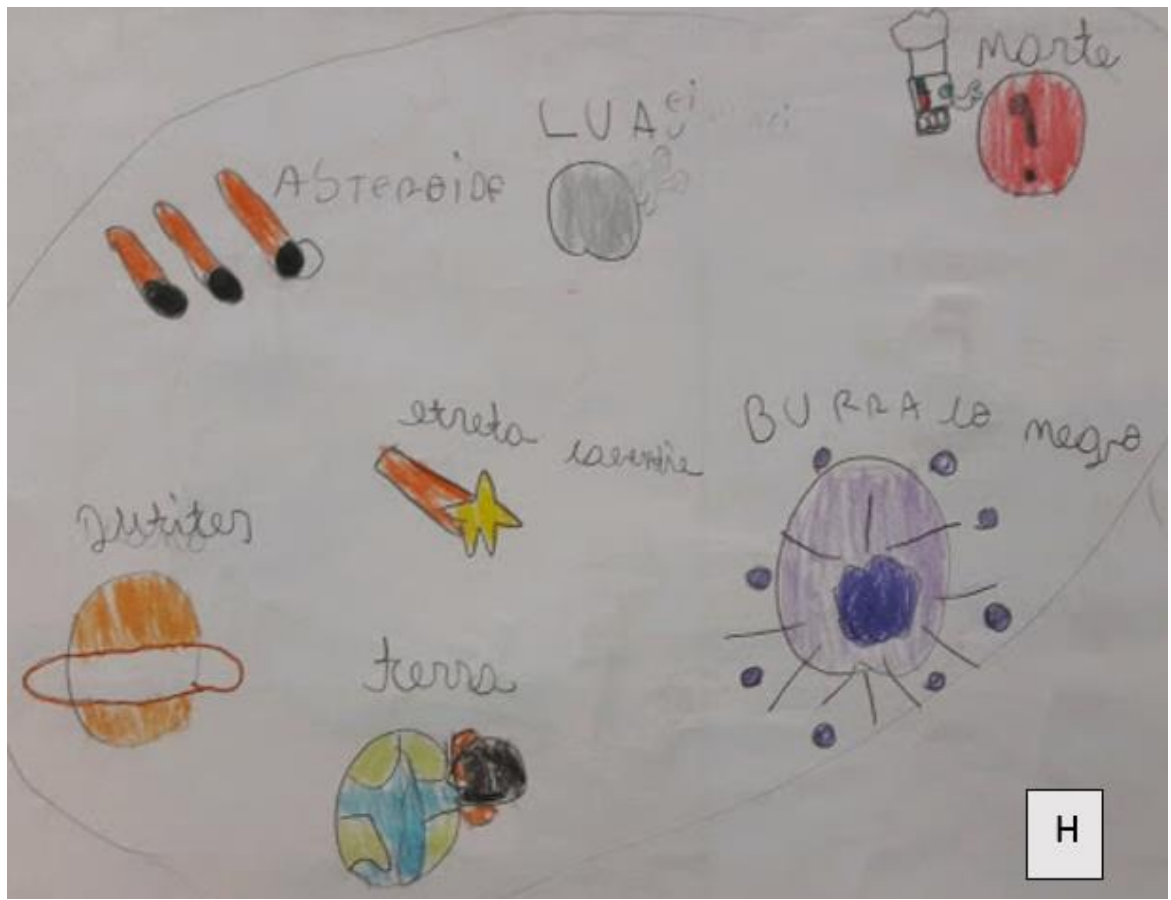

Figura 76 - Desenhos de outros corpos celestes

Os desenhos dos estudantes nos revelam uma riqueza de conhecimentos diversos. Nota-se que os estudantes já tiveram o contato com este tema, pois nenhum aluno se recusou a desenhar. Percebemos que há desenhos com mais elementos e outros com menos, entretanto é possível afirmar que os alunos já compreendem que existem planetas, além da Terra.

A figura A representa uma configuração de Sistema Solar, com o Sol no centro, mas sem os planetas estarem na ordem correta. Os oitos planetas do Sistema Solar estão desenhados, além de estrelas, Lua e Sol. Na figura B é possível observar que o aluno desenhou diversos planetas variando inclusive em tamanho e cores. Na figura 
C, é possível observar a inclusão de outros elementos como nave espacial, a Via Láctea e "meteoros" (sic). Na figura D e F percebe-se que os desenhos apresentam menos elementos, mas os estudantes já conseguem nomear alguns astros, com Marte e Saturno aparecendo em ambos. A figura E apresenta uma bandeira, que possivelmente é a bandeira colocada pelos Estados Unidos na Lua, e ao fundo um planeta, que pode ser a Terra. A figura $G$ apresenta a estrutura de uma galáxia. E por fim a figura $\mathrm{H}$ nos apresenta outros elementos, como asteroides, buraco negro e estrela cadente.

Todos estes desenhos revelam que apesar da diferença de conhecimentos entre os estudantes estes poderão colaborar e descobrir muitas coisas novas com a Sequência Didática proposta. Ao final deste capítulo, será apresentado a análise do questionário final e novos desenhos produzidos pelos estudantes acerca de sua aprendizagem.

Concluimos até aqui que os estudantes já ouviram falar de alguns planetas, mas poucos alunos conhecem todos os planetas do Sistema Solar. Há alunos que já reconhecem, além dos planetas outros corpos celestes como asteroides, meteoroides, cometas, etc. Alguns estudantes vão além, mencionando galáxias e buracos negros. Fica nítido que alguns estudantes já ouviram falar nas conquistas espaciais, nas sondas enviadas a Marte e que Saturno é um planeta que é muito representado, principalmente pelos seus anéis. Há estudantes que já realizaram desenho do Sistema Solar, inclusive representando órbitas.

5.3 - Análise das tarefas e pesquisas encaminhadas aos estudantes durante a aplicação da SD.

Durante os encontros os estudantes realizaram diversas atividades em sala de aula, e na maioria das vezes, ao final de uma aula, os alunos levaram atividades para realizarem em casa. A seguir será apresentado o material coletado pelos estudantes nesse período. Acreditava-se que durante a aplicação da SD se fazia necessária uma retomada do assunto pelos estudantes em casa, para aprofundamento e troca de conhecimentos como os colegas de turma.

A primeira tarefa proposta aos alunos foi pesquisar uma lenda ou mito que explicasse a origem do mundo. Esperava-se que por meio da mediação realizada pela 
professora com as lendas coletadas, os estudantes pudessem compreender que os povos antigos buscavam respostas para sua origem, e como não sabiam explicar como tudo tinha ocorrido, inventavam histórias. Sendo assim, a aula seguiria com a leitura de uma lenda proposta pela professora para aprofundamento e debate, como se explicou no capítulo 4.

Participaram da pesquisa 27 alunos. Alguns estudantes consultaram seus familiares para responder, mas a maioria utilizou o recurso da internet para buscar as informações.

Analisando o material trazido pelos alunos foi possível observar que apesar dos estudantes terem feito a atividade, 40,7\% não encontrou uma lenda, e sim apenas escreveu um texto (cópia) da internet que explicava o que era mitologia. Também seis alunos, que compõe 22,2\% dos estudantes apresentaram a Teoria do Big Bang ao invés de uma lenda. Entretanto, alguns alunos apresentaram mitos interessantes e esboçaram também concepções religiosas acerca da criação do mundo. A tabela 10 resume a coleta destas informações:

\begin{tabular}{|l|c|c|}
\hline \multicolumn{3}{|c|}{ Mitos ou lendas } \\
\hline Indígena & 2 & $7,4 \%$ \\
\hline Relato religioso & 2 & $7,4 \%$ \\
\hline Africano & 2 & $7,4 \%$ \\
\hline Científico & 6 & $22,2 \%$ \\
\hline Aborígenes da Austrália & 1 & $3,7 \%$ \\
\hline Não encontrou mito/lenda & 11 & $40,7 \%$ \\
\hline Mitologia mesopotâmica & 2 & $7,4 \%$ \\
\hline Mitologia egípcia & 1 & $3,7 \%$ \\
\hline Total: & 27 & $100 \%$ \\
\hline
\end{tabular}

Tabela 10 - Pesquisas realizadas pelos alunos sobre mitos que contam a origem do mundo

Observa-se na figura 77 um trecho de um mito de origem africana para explicar a origem do mundo: 


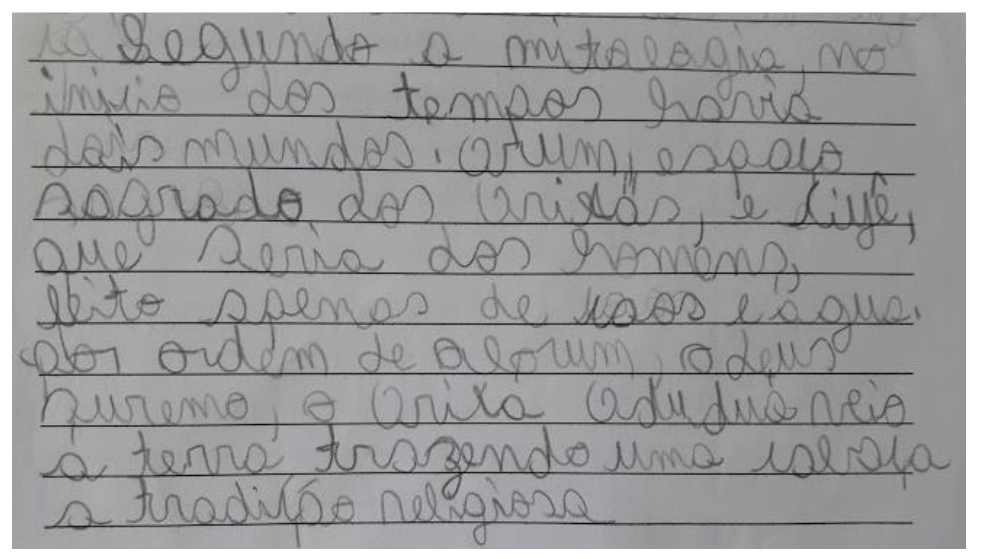

Figura 77 - Pesquisa apresentada sobre lendas para a origem do mundo

Ao ler as pesquisas apresentadas, notamos uma diversidade de culturas presentes entre os estudantes e também o interesse em buscar informações. Observa-se também o cuidado com a escrita e em manter o texto integral na pesquisa. Notamos este cuidado na apresentação de um conto criado pelos aborígenes australianos, como demonstra-se no trecho da figura 78 :

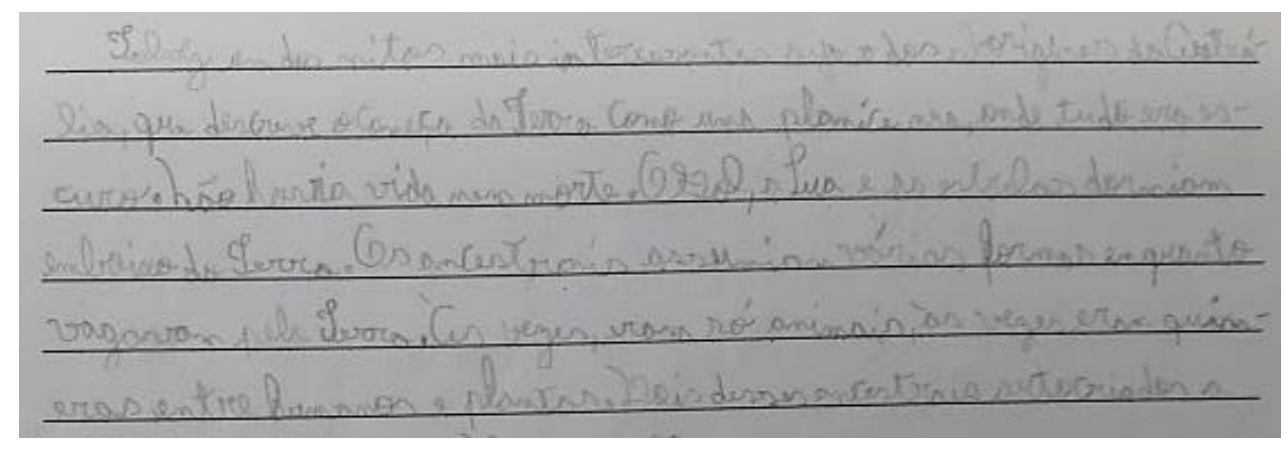

Figura 78 - Pesquisa apresentada sobre lendas para a origem do mundo

Reunir estas informações na aula foi fundamental, pois possibilitou aos estudantes a reflexão de que não existe uma única história para contar a origem do mundo, e que sim, o que existe são muitos povos que criaram suas histórias e suas próprias explicações. A atividade permitiu ainda ampliar o repertório dos estudantes com contato de outros mitos, e prepará-los para o estudo e leitura de mitos que seriam propostos adiante pela SD. Além disso, estariam preparados para conversarem e debaterem sobre a explicação científica da origem do Universo, e saber diferenciar e compreender a importância de cada uma.

No momento da exposição das pesquisas foi também priorizado o cuidado e respeito com concepções religiosas, pois nosso foco era a pesquisa e a diversidade 
de informações sobre o tema, e oportunizar a participação dos estudantes. A figura 79 mostra um fragmento de texto:

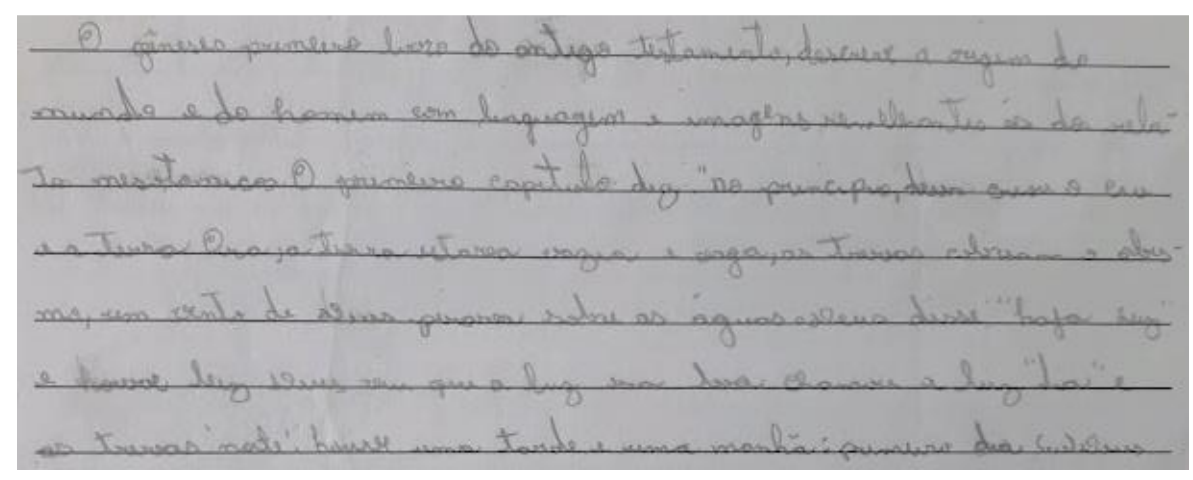

Figura 79 - Pesquisa apresentada sobre lendas para a origem do mundo

Os estudantes apresentaram também fragmentos da teoria do Big Bang, mas é perceptível que apenas copiaram o texto da internet, sem qualquer orientação. $O$ texto não corrobora a proposta inicial, e é possível que nem os próprios estudantes tenham compreendido o que de fato escreveram. Entretanto, durante a aula, alguns estudantes citaram a teoria, de forma resumida (Figura 80). Não deixou de ser interessante esta participação, porque ao final desta aula sobre os mitos, se chegaria a construção da diferença entre o mito e a busca por respostas da Ciência.

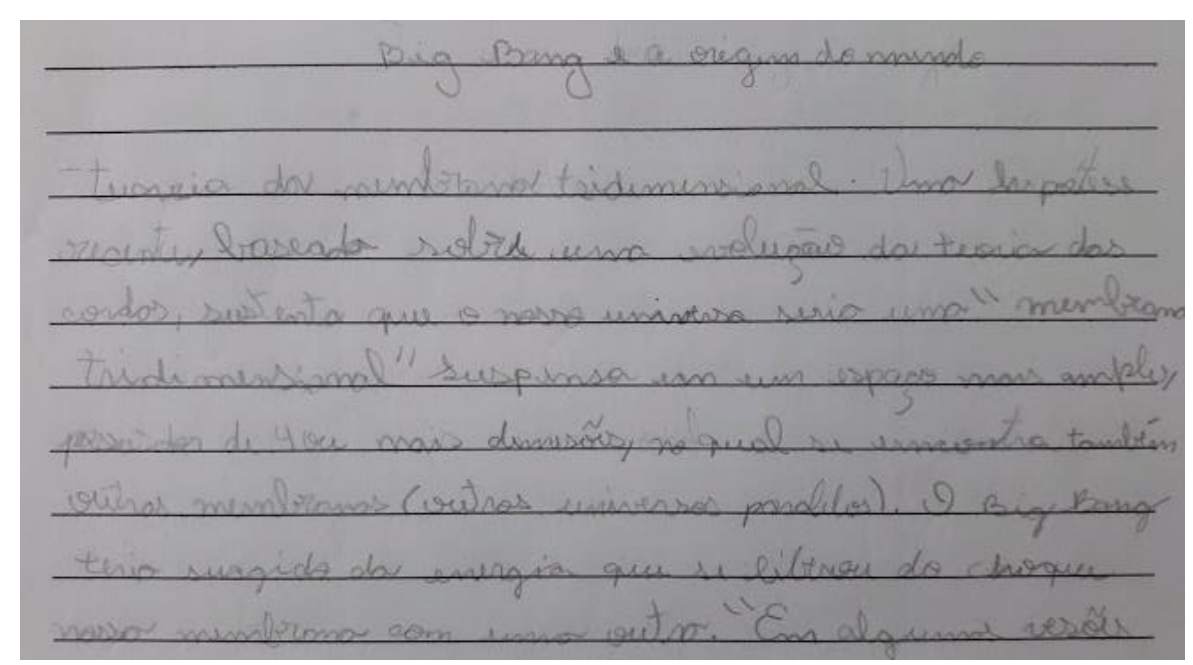

Figura 80 - Pesquisa apresentada sobre lendas para a origem do mundo

O objetivo da proposta nesta atividade foi alcançado, mas talvez direcionar melhor a pesquisa poderia ser uma boa solução para que os alunos encontrassem textos com maior qualidade. Esta atividade poderia ser realizada junto com os professores de biblioteca e/ou sala de leitura ou com o professor do laboratório de informática, pois os alunos teriam mais suporte e orientação. 
A atividade proposta na terceira aula consistia em ampliar o repertório de leitura dos estudantes oferecendo um mito grego, o mito de Andrômeda. Para tanto a professora autora/aplicadora elaborou uma atividade para ser impressa e entregue aos estudantes. Na atividade além do texto, eram propostas algumas questões de inferência (que não analisaremos nesta pesquisa) e introduzia-se o assunto da constelação de Andrômeda, mostrando um fragmento de uma carta celeste o asterismo que compõe a constelação, reproduzido na figura 81:

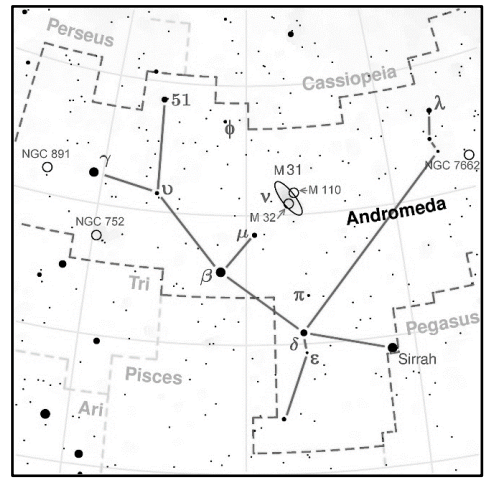

https://pt.wikipedia.org/wiki/Andr\%C3\%B4meda (constela\%C3\%A7\%C3\%A30)

Figura 81 - Constelação de Andrômeda

A pergunta principal feita aos estudantes era se eles conseguiam visualizar na imagem uma princesa. Dos vinte e cinco alunos que entregaram a tarefa, 20\% afirmaram conseguir e $80 \%$ disse que não conseguia observar. A seguir, algumas justificativas:

- Concordando:

Aluno 3 "Sim, porque parece tanto os braços com as pernas e a cintura" Aluno 17 "Não, mas se você usar a imaginação consegue ver a Andrômeda"

- Discordando:

Aluno 19: "Não, só vejo linhas e pontos"

Aluno 25: "Não porque a direção das estrelas não formam uma princesa"

Aluno 9: "Não porque para mim parece uma pessoa correndo"

O objetivo desta questão era trazer para o momento da socialização das respostas o debate sobre a construção de como se criaram as constelações, permitindo que os alunos conseguissem compreender que ela é muito semelhante à brincadeira que se faz ao observar nuvens no céu e dizer o que elas parecem. A 
discussão é ainda ampliada quando a professora aplicadora explica que estas mesmas estrelas ou parte delas, em outras culturas recebem outros nomes e outros formatos.

A questão final proposta nesta atividade era incentivar os alunos a criarem uma nova constelação a partir das estrelas, que estavam representadas como pequenos pontos no papel. Apresentou-se os pontos e os estudantes ficaram livres para criar. As figuras 82 a 93 trazem algumas respostas:

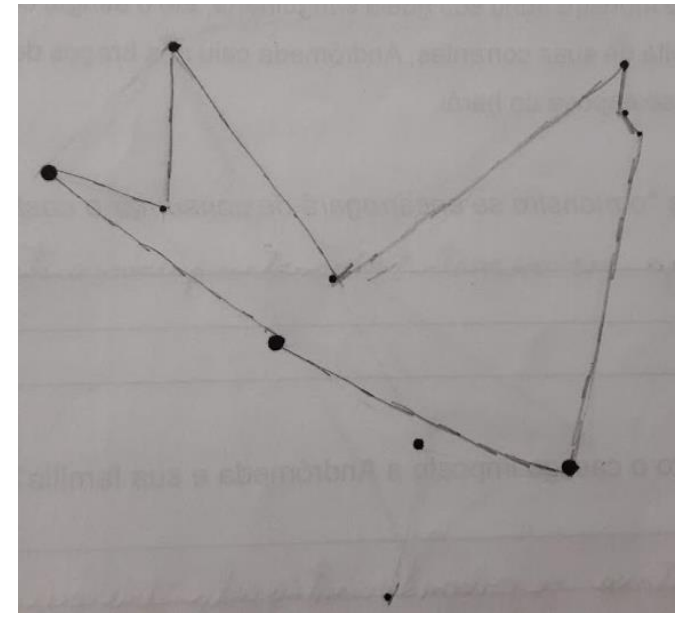

Figura 82 - Sapato de um duende

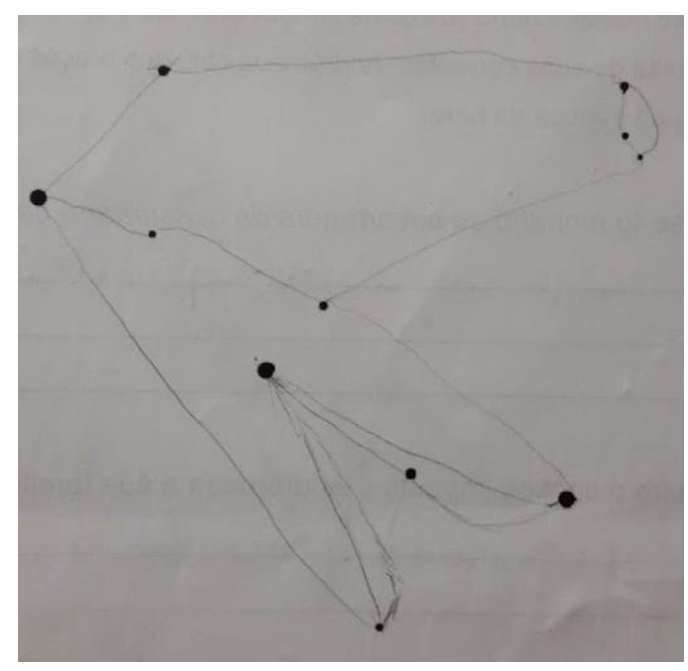

Figura 84 - Telescópio

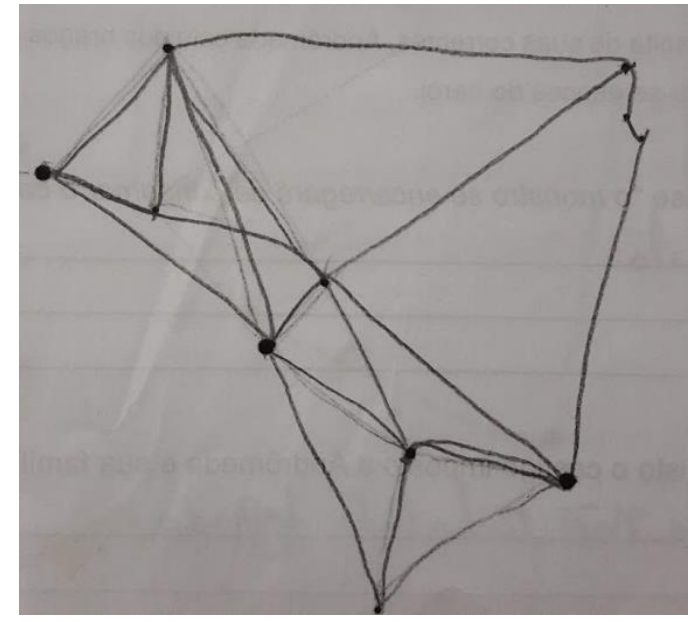

Figura 83 - Cabana de baixo

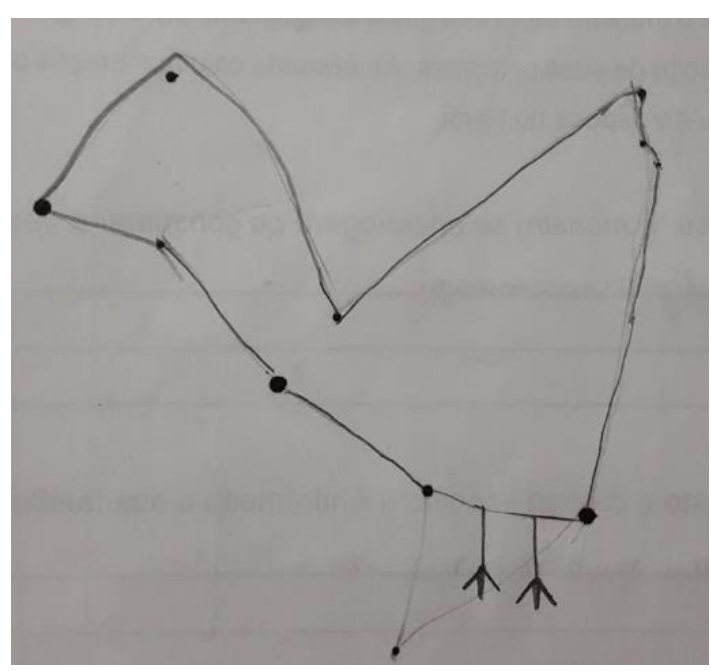

Figura 85 - Passageiro 


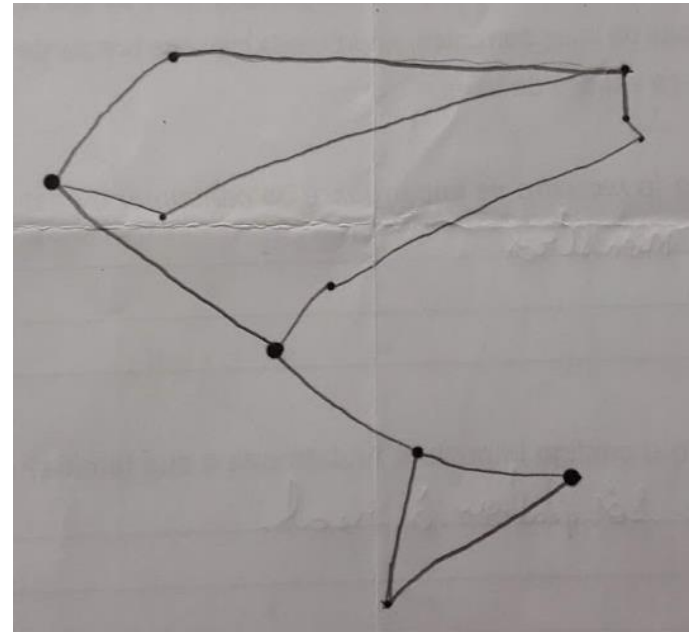

Figura 86 - Arma

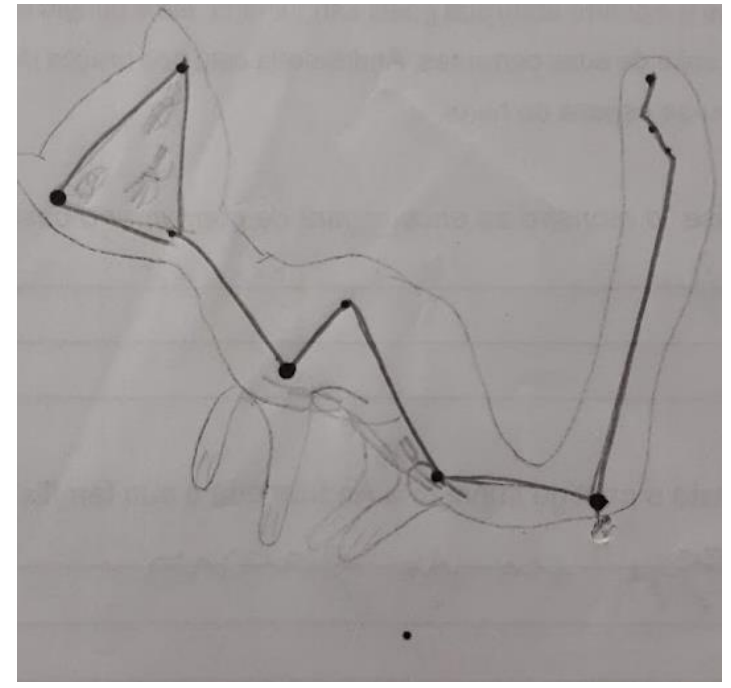

Figura 88 - Gato

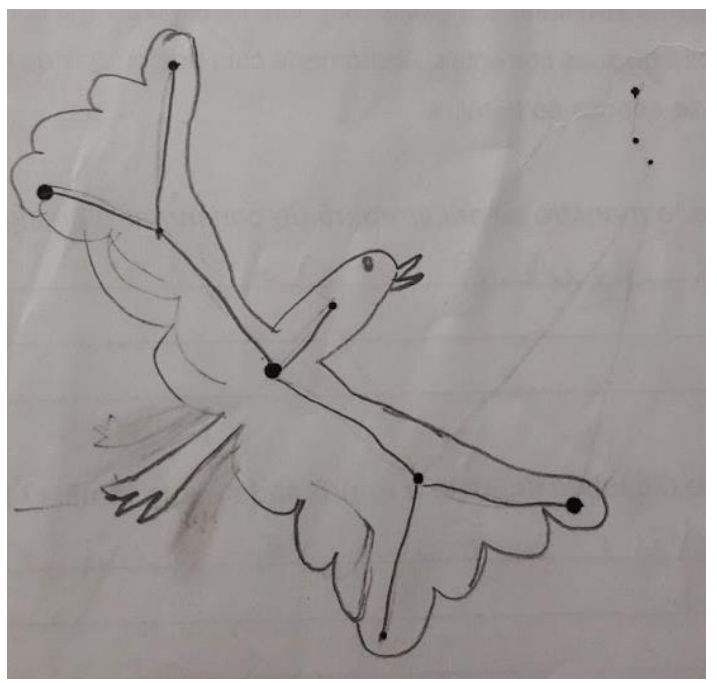

Figura 90 - Pássaro

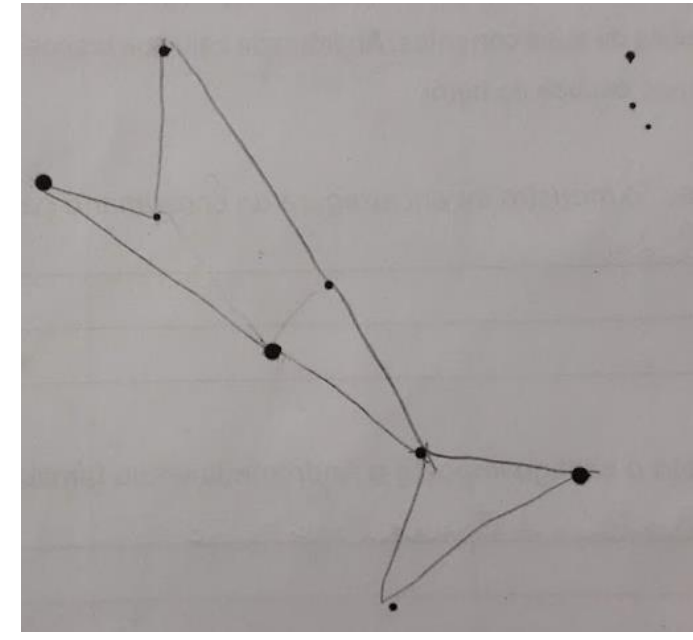

Figura 87 - Tubarão

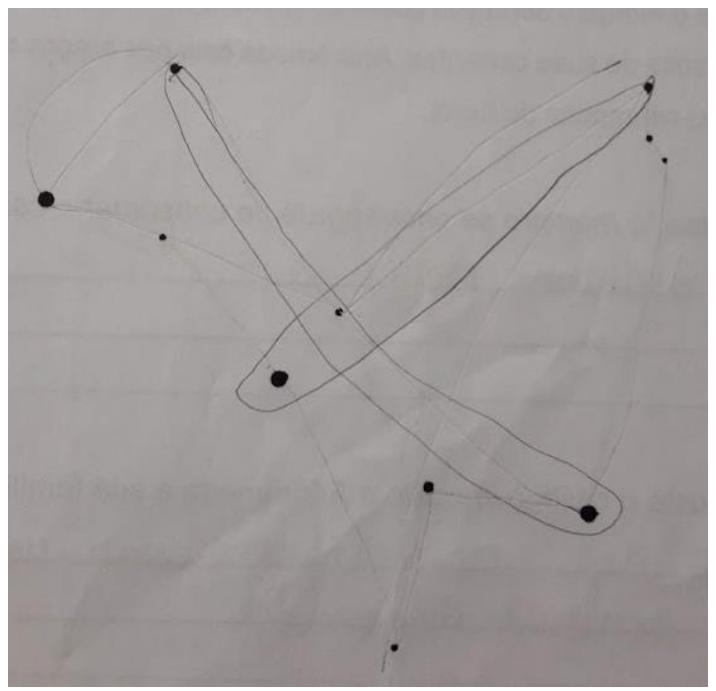

Figura 89 - Espada

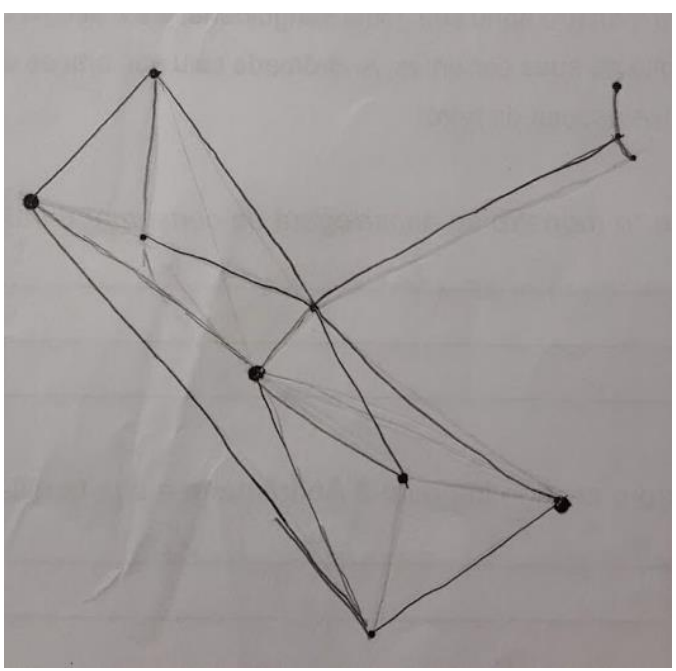

Figura 91 - Placa solar 


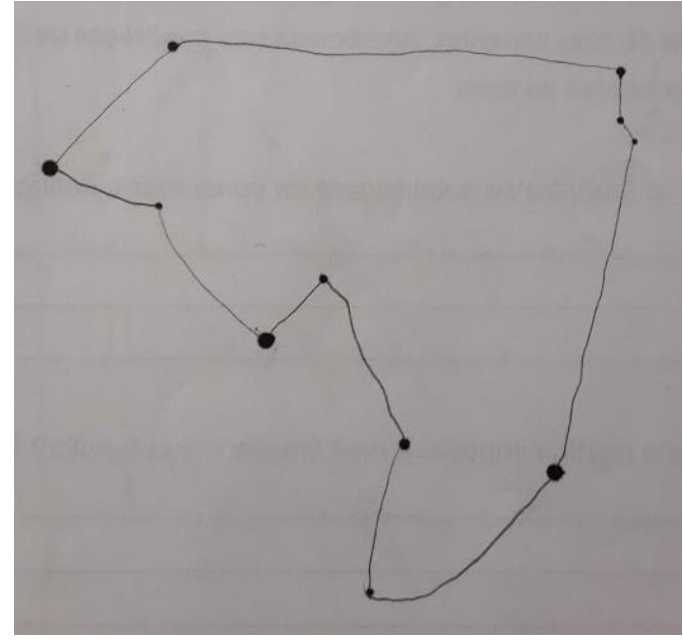

Figura 92 - Brasil

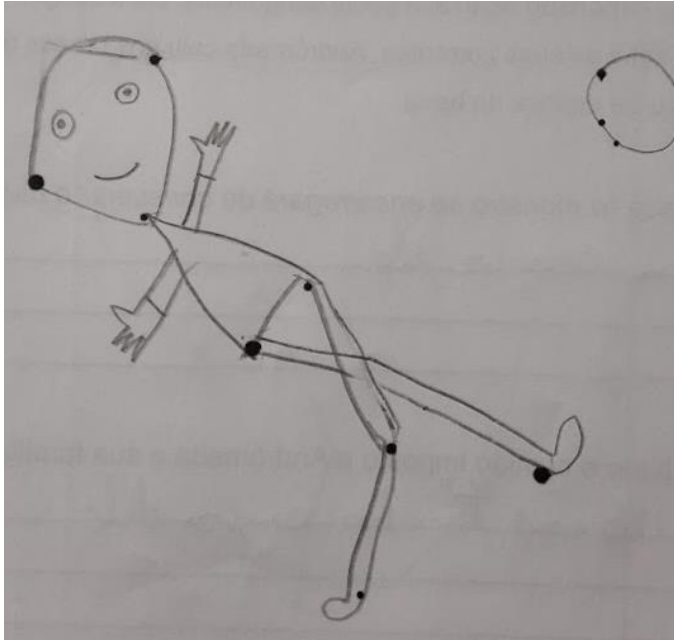

Figura 93 - Menino jogando bola

Durante a socialização desta atividade, foram projetados no quadro os pontos para os estudantes irem desenhar as imagens que conseguiram imaginar. Com este exercício ficou mais simples para os alunos compreenderem como as constelações foram "criadas" e porque a princípio elas podem "não fazer sentido para o observador".

Para ampliar o repertório dos estudantes a professora utilizou imagens do software Stellarium para mostrar que ao redor da constelação de Andrômeda estão outros personagens da história que leram, como Cassiopeia e Perseu, por exemplo.

A atividade proposta ao final da aula 4 foi uma pesquisa sobre o Sol, que continha os seguintes tópicos:

- Do que ele é formado?

- Qual é a distância da Terra até o Sol?

- Qual é o seu tamanho em diâmetro?

- Quanto mede sua temperatura?

- Curiosidades para compartilhar

- Fontes.

A proposta desta pesquisa era orientar melhor os estudantes quanto a forma de procurar informações, além de permitir que os alunos já antecipassem sua pesquisa e participassem da aula sobre o Sol com informações que seriam abordadas na aula. Desta vez a professora orientou os estudantes para que anotassem a fonte de pesquisa, explicando a importância desta prática. Também a professora estava interessada nas informações de "Curiosidades" que os alunos conseguiriam encontrar para compartilhar. O foco desta atividade não era "acertar", e sim, incentivar a 
pesquisa mais aprofundada. Ela serviria para iniciar o tema da aula sobre o Sol, e os demais itens pesquisados seriam esclarecidos com mais cuidado na própria aula.

A atividade contou com a participação de 21 estudantes. A primeira questão sobre "Do que o Sol é formado?", 71,4\% dos estudantes acertaram a resposta, escrevendo que a principal composição do Sol é hidrogênio e hélio, e ainda alguns citaram outros componentes em menor quantidade. Alguns estudantes não acertaram a questão, compondo $4,8 \%$ e os estudantes que erraram, compostos por $23,8 \%$ possivelmente não entenderam que a questão queria saber a composição do Sol, e pensaram que era para pesquisar como é sua formação "física".

A questão “Qual é a distância da Terra ao Sol?”, 90,5\% dos estudantes responderam corretamente com $149600000 \mathrm{~km}$ (cento e quarenta e nove milhões e seiscentos mil quilômetros). Esta questão seria interessante ser abordada mais adiante nas aulas de matemática, pois no $5^{\circ}$ ano inicia-se a leitura de números maiores que milhões, e utilizar os próprios números trazidos pelos estudantes na pesquisa contextualizaria esta aprendizagem e poderia ser utilizada inclusive em trabalhos futuros.

A questão “Qual é o seu tamanho (diâmetro)?”, 71,4\% dos alunos conseguiram responder $1.391 .016 \mathrm{~km}$, enquanto $28,6 \%$ trouxe outras informações que não correspondiam com a realidade. Nesta aula, durante a socialização das respostas será explicado aos estudantes o conceito de diâmetro e porque ele é tão utilizado nas informações sobre os astros em enciclopédias.

O levantamento dos estudantes sobre "Curiosidades" do Sol, revelou várias informações interessantes, tais como:

Aluno 4: "A luz do Sol leva oito minutos para chegar até a Terra";

Aluno 13: "O Sol é a estrela mais próxima de nós, habitantes do planeta Terra, e é basicamente uma grande esfera de gás";

Aluno 22: "O Sol é uma estrela e todos os planetas giram em torno dele".

A pesquisa sobre o Sol, revelou ainda algumas informações das quais não esperávamos que fosse aparecer. Alguns estudantes aproveitaram o campo "Curiosidades" para escrever perguntas sobre o Sol, um estudante perguntou "quanto tempo se leva para chegar ao Sol?" e outro estudante revelou "Eu não sabia que o Sol é uma estrela". O compartilhamento das informações da pesquisa durante a aula foram fundamentais para que os estudantes pudessem iniciar o estudo sobre o Sol 
com conhecimentos prévios e perguntas já elaboradas para ampliarem seu conhecimento.

$\mathrm{Na}$ aula 5, os alunos deveriam investigar o que são auroras boreais e austrais, tentar descobrir como ocorre o fenômeno e fazer um desenho de observação da imagem. A atividade consistia em ampliar a discussão que os alunos tiveram previamente durante a leitura de um texto sobre o Sol, o qual falava rapidamente das auroras. Esta atividade obteve pouca participação dos estudantes, sendo que apenas 16 alunos entregaram. Na primeira pergunta da atividade os alunos deveriam responder "O que é aurora boreal ou austral?", e todos os estudantes conseguiram responder. O aluno 4 escreveu "São verdadeiros shows de luzes coloridas e brilhantes que ocorrem em função do contato dos ventos solares com o campo magnético do planeta Terra"; o aluno 10 escreveu "É um fenômeno óptico composto de um brilho observado nos céus noturnos". A questão 2 perguntava "Como ocorre o fenômeno?", apenas $31,3 \%$ dos estudantes conseguiram explicar corretamente o fenômeno; entretanto $50 \%$ conseguiu associar o fenômeno às partículas emitidas pelo Sol que entram em contato com a Terra, mas sem se aprofundar na resposta sobre o campo magnético; e 18,8\% não conseguiu responder. Sendo assim, se faz necessário após a devolutiva dessa atividade o professor aplicador explicar o fenômeno de uma forma simples, mas que seja efetiva para a compreensão dos estudantes.

Para finalizar, os alunos deveriam fazer um desenho de observação de uma fotografia, mostrando o fenômeno. As figuras 94, 95 e 96 trazem alguns desenhos apresentados:
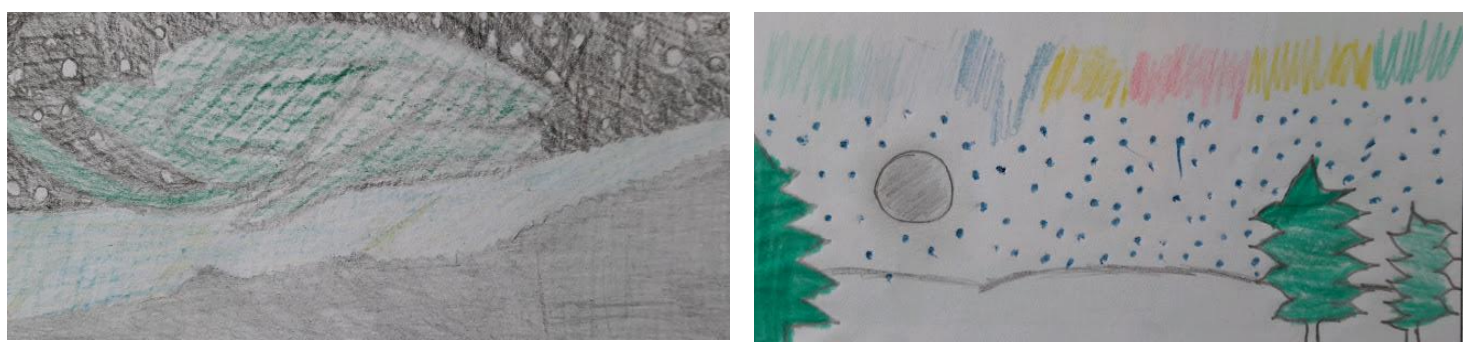

Figura 94 - Desenhos de observação sobre as auroras
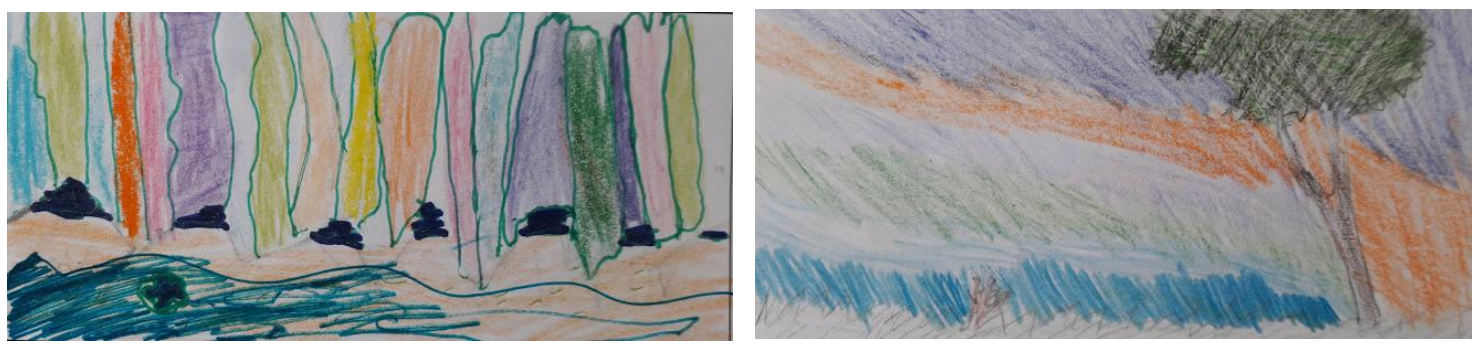

Figura 95 - Desenhos de observação sobre as auroras 


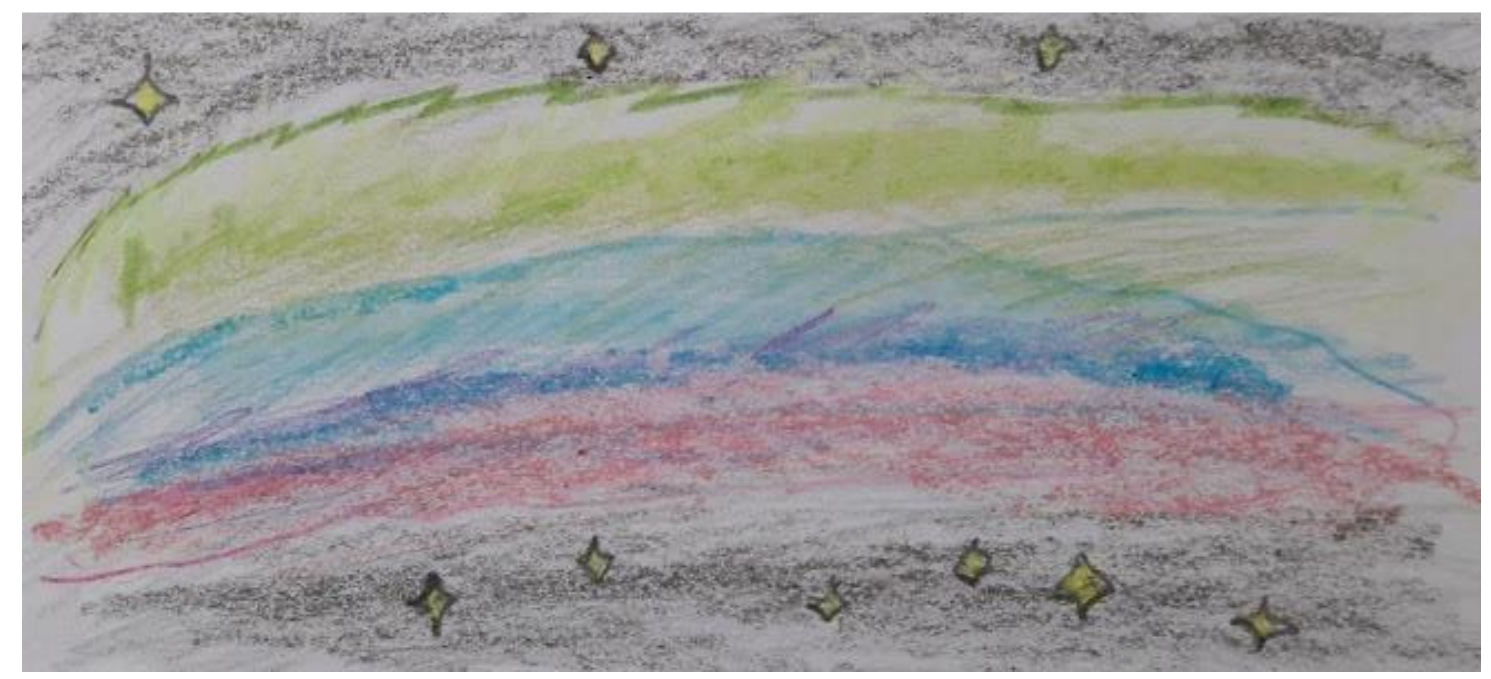

Figura 96 - Desenho de observação sobre as auroras

A atividade proposta na aula 6 tratava da análise do fragmento da música " $A$ Lua", do grupo musical MPB-4. Na atividade os alunos deveriam realizar a leitura, responder a algumas questões de interpretação de texto. Ao final, sugeria-se aos estudantes que desenhassem a Lua e tentassem escrever qual era o nome dela nesta fase. Desejava-se com esta atividade procurar descobrir como os estudantes observavam a Lua e se sabiam nomear alguma fase popularmente conhecida.

Durante a socialização da atividade a professora abordaria com a turma os diferentes desenhos para que os estudantes pudessem reunir seus conhecimentos prévios e aprofundar o que já sabem sobre o satélite durante a aula. Esta atividade foi entregue por 26 estudantes. A maior representação pelos alunos foi da Lua Cheia, contando com 17 desenhos desta fase. As figuras 97 e 98 trazem algumas representações:
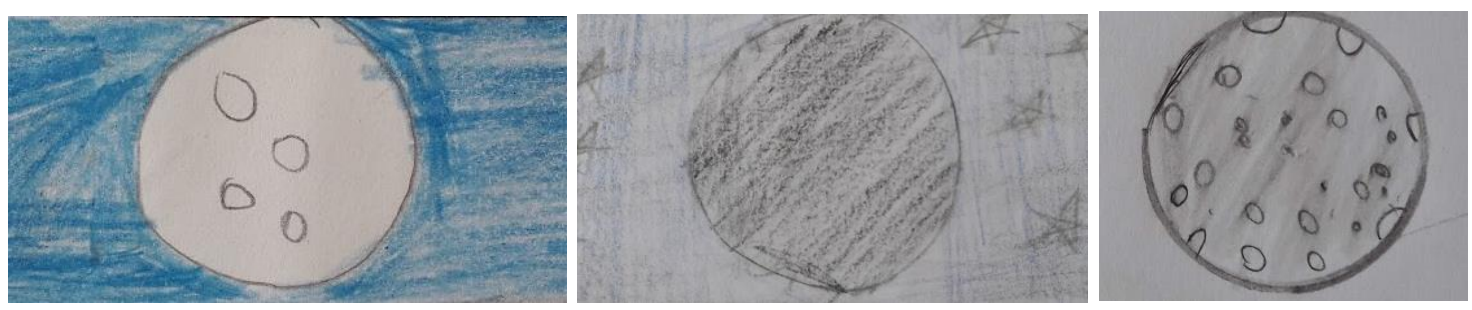

Figura 97 - Desenhos sobre as fases da Lua
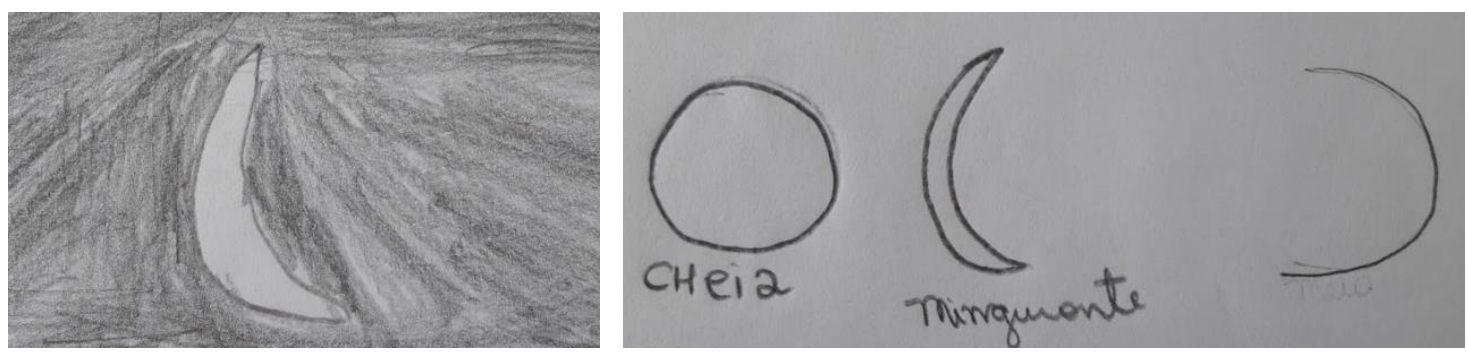

Figura 98 - Desenhos sobre as fases da Lua 
Ao final da aula 7 , os alunos deveriam pesquisar as respostas para as perguntas elaboradas durante a aula, que não foram respondidas por meio da leitura e dos vídeos que assistiram. As perguntas que faltavam ser respondidas eram as seguintes:

- Do que a Lua é feita?

- É possível construir casas na Lua?

- O que há no núcleo da Lua?

- O que são estas coisas redondas na Lua, que faz ela parecer um queijo? (pois os estudantes não conseguiram entrar em um acordo na aula sobre esse assunto).

Durante a socialização das respostas encontradas, a professora pode perceber que apenas 7 alunos tinham realizado a atividade. Quando questionados, os alunos disseram que não tiveram tempo de pesquisar. A professora reiterou a importância de se pesquisar para que todos consigam aprender, e combinou com a turma que em uma outra situação eles serão mais responsáveis. $O$ aluno 6 disse que descobriu que "a Lua é feita de rochas e poeira, e tem basalto que é uma rocha que também tem aqui na Terra, que se forma quando tem vulcões", o aluno 19 concordou com o colega, dizendo que tinha encontrado a mesma resposta. O aluno 10, aproveitou e disse: "Quando eu procurei essa resposta, descobri que o núcleo da Lua é feito de ferro", outros alunos concordaram com ele. A professora elogiou a turma pela pesquisa, e perguntou se alguém tinha descoberto se era possível construir casas na Lua. Alguns estudantes responderam que não tinham encontrado, então um levantou a mão e disse: "Não existe casa na Lua, professora. Mas, eu achei na internet que querem construir, chama casa lunar inflável." O aluno 10 respondeu: "Eu li isso também. Mas ainda não construíram. É só teste”. A professora então procurou explicar que sim, que estão realizando pesquisas, mas que por enquanto não foi construída uma casa na Lua, mas que as pesquisas e os estudos estão caminhando para que isso aconteça em breve. E para finalizar a professora relembrou a turma da última questão: "Pessoal, vocês descobriram o que são estas coisas redondas na Lua?”. O aluno 19 levantou a mão e disse: "São as crateras, isso acontece por causa do choque de meteoros, porque a Lua não tem atmosfera pra se proteger, como a Terra tem". O aluno 3 concordou e disse que escreveu isso também. Sendo assim, finalizou-se a socialização das respostas para esta atividade. 
Durante a aula 8, os estudantes elaboraram perguntas que queriam descobrir sobre os planetas e se dividiram em grupos para poder encontrar estas respostas e elaborar um cartaz. Cada grupo se reuniu para compartilhar com seus colegas de grupo as informações encontradas. Durante a organização do cartaz foi possível observar que os estudantes estavam comprometidos com a atividade, pois trouxeram informações impressas, imagens e também estavam interessados em encontrar mais informações nas enciclopédias disponíveis. Os cartazes apresentados contavam com informações diversas, tais como: características gerais dos planetas, curiosidades e imagens.

A figuras 99 a 107 trazem os cartazes confeccionados bem como nossa análise sobre as produções:

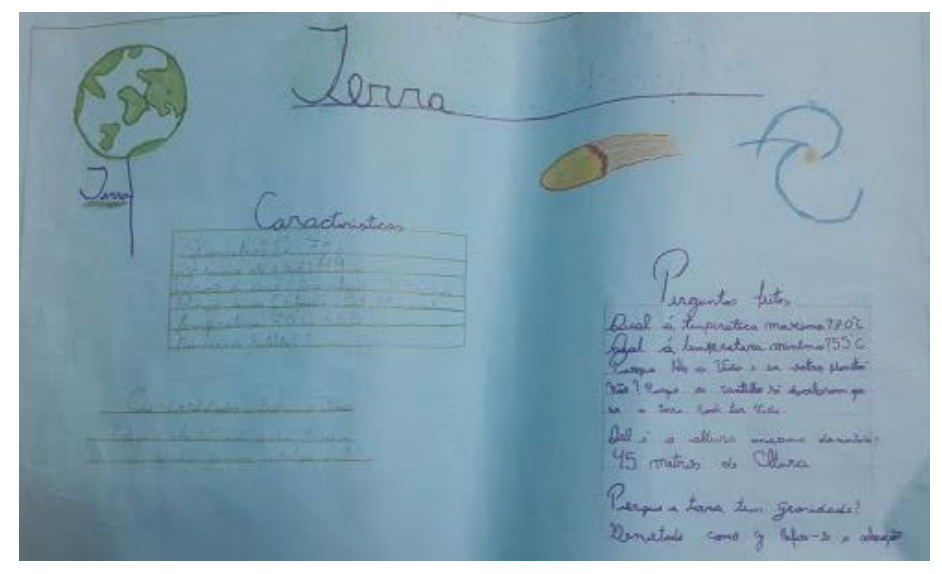

Figura 99 - Cartaz Terra

O cartaz sobre a Terra apresentou várias informações das características do planeta, e obteve mais respostas às perguntas criadas na aula anterior. É possível que os alunos tenham tido mais facilidade em encontrar as informações sobre a Terra porque ele é o planeta no qual vivemos. Os alunos não puderam realizar impressões, mas fizeram desenhos para ilustrar o trabalho, mostrados na figura 99.

O grupo de pesquisa sobre Urano encontrou a resposta para a pergunta "Existe vida?" e também trouxeram uma curiosidade explicando a cor do planeta, afirmando que o azul não é água. Não trouxeram imagens impressas, mas procuraram ilustrar com desenhos (Figura 100). 


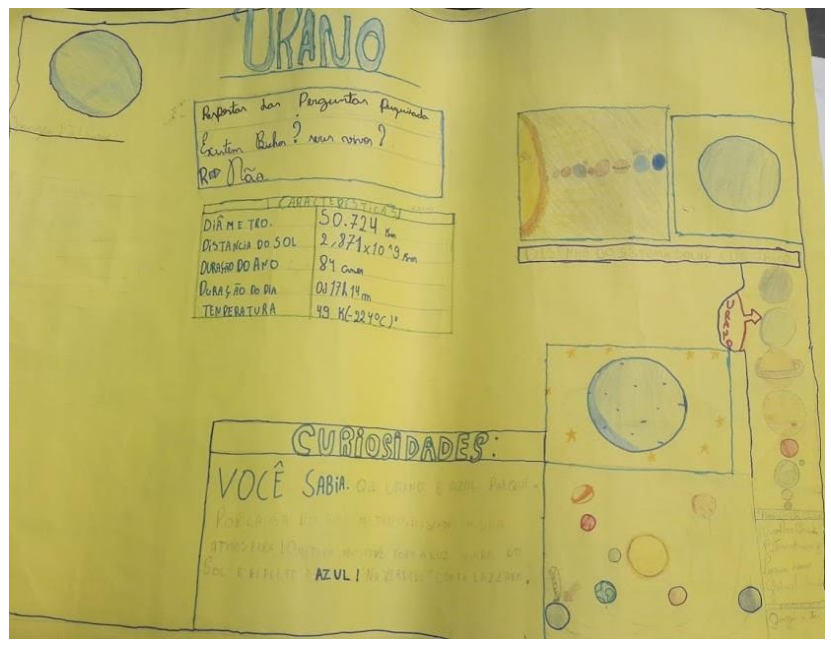

Figura 100 - Cartaz Urano

O cartaz sobre Marte apresentou várias imagens sobre o planeta, mas não conseguiu se organizar de modo a responder as perguntas elaboradas pela turma. A dificuldade dos estudantes não foi encontrar as respostas e sim se organizar para que conseguissem realizar a atividade. No dia do trabalho, nem todos os alunos trouxeram a parte que Ihes cabia pesquisar, eles tentaram procurar algumas respostas em enciclopédias, mas só conseguiram registrar a resposta de uma. Entretanto no dia da apresentação, os estudantes conseguiram trazer mais algumas informações que não foram registradas no cartaz, mas que foram ditas oralmente (Figura 101).

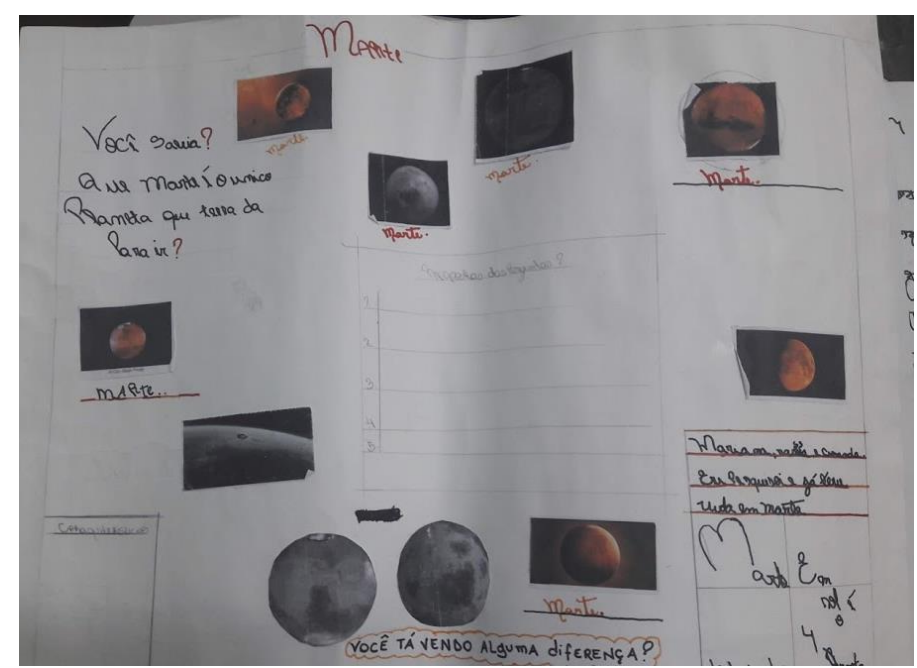

Figura 101 - Cartaz Marte

O grupo responsável por trazer informações sobre Plutão conseguiu alcançar o objetivo proposto, a apesar de não terem conseguido se aprofundar nas respostas, demostraram responsabilidade, organização e interesse (Figura 102). 


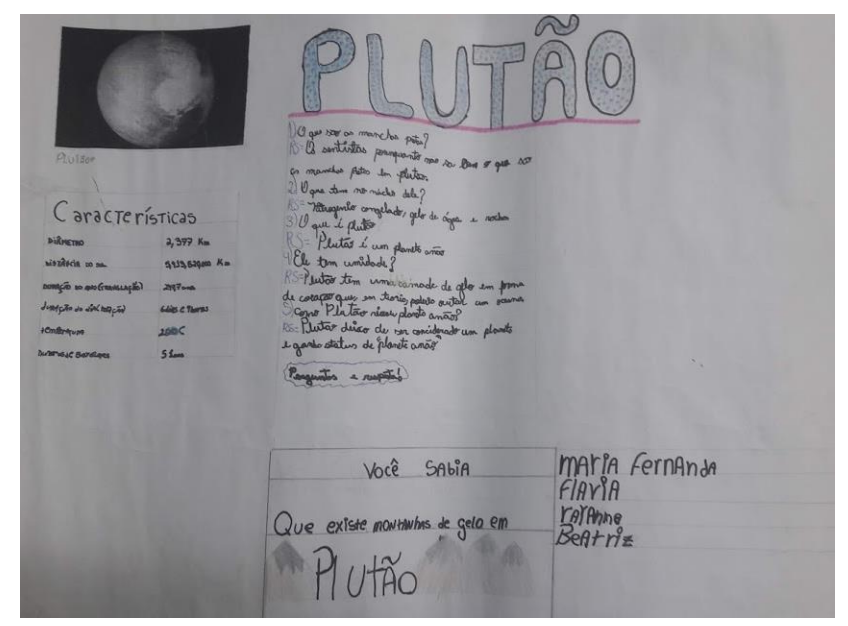

Figura 102 - Cartaz Plutão

O grupo responsável pela pesquisa de Netuno se organizou bem, e os alunos dividiram as tarefas e conseguiram equilibrar bem as informações que precisavam ser encontradas. Os estudantes encontraram a resposta de quatro perguntas, mas como não transcreveram a pergunta no cartaz, ficou confuso a compreensão das informações (Figura 103).

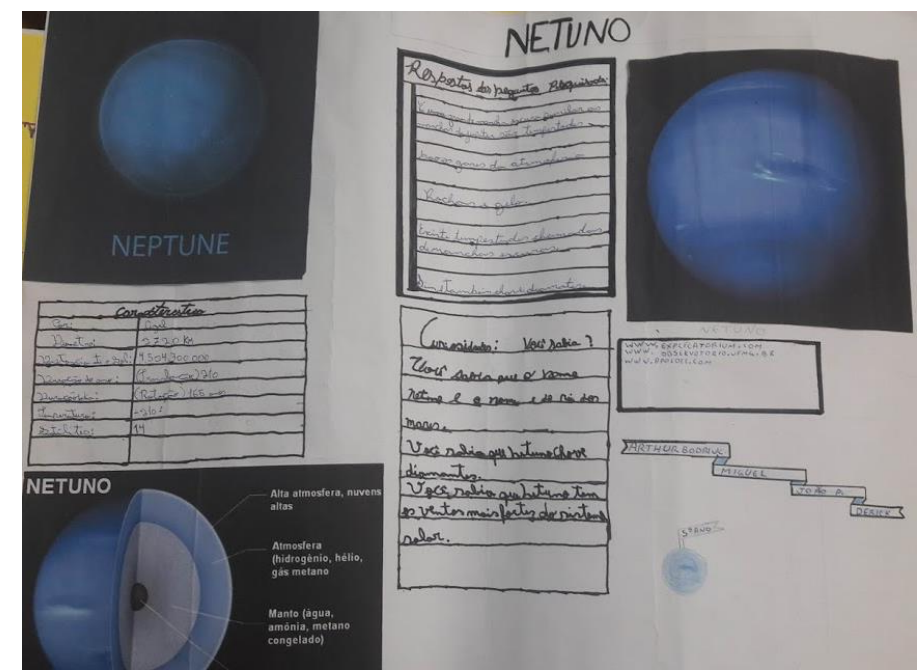

Figura 103 - Cartaz Netuno

O grupo responsável por pesquisar informações de Saturno também apresentou uma boa organização. Conseguiram equilibrar bem informações e imagens. Também optaram por escrever no cartaz apenas as respostas das perguntas, mas durante a apresentação conseguiram explicar tudo de forma clara (Figura 104). 


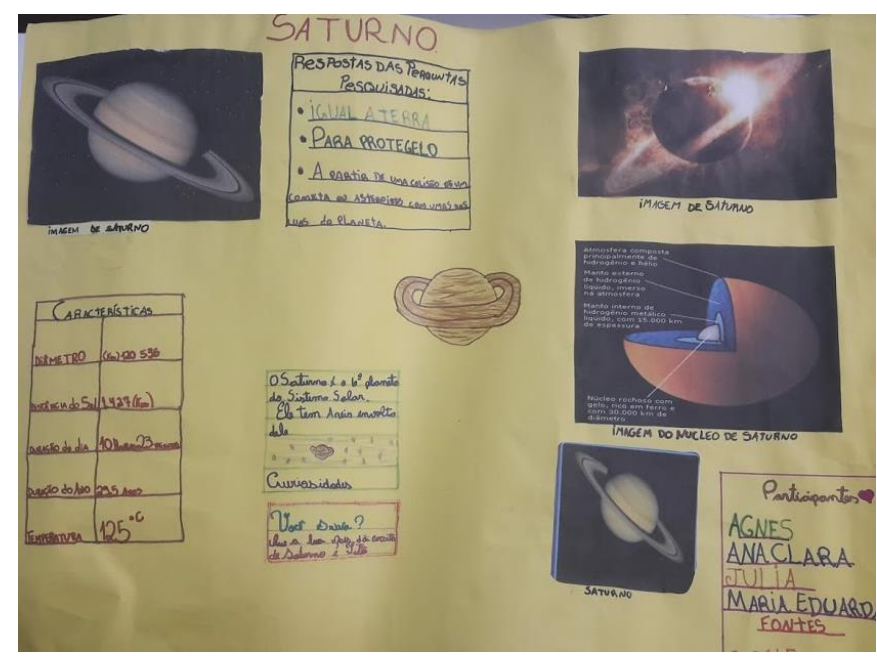

Figura 104 - Cartaz Saturno

O grupo que pesquisou as informações sobre Júpiter também se organizou bem, mas não conseguiu encontrar a resposta de todas as perguntas. Procuraram trazer uma imagem e fizeram mais uma ilustração (Figura 105).

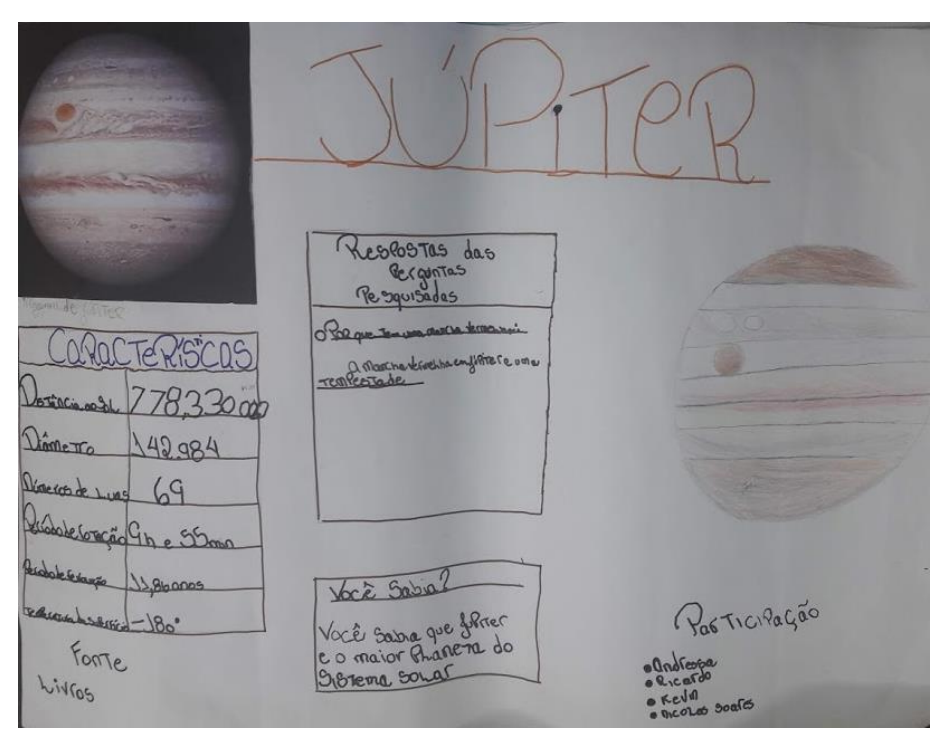

Figura 105 - Cartaz Júpiter

O grupo responsável por pesquisar informações sobre Vênus conseguiu se organizar bem, equilibrando informações e imagens. Não trouxeram a resposta de todas as perguntas feitas, mas foram cuidadosos em trazer uma resposta completa (Figura 106). 


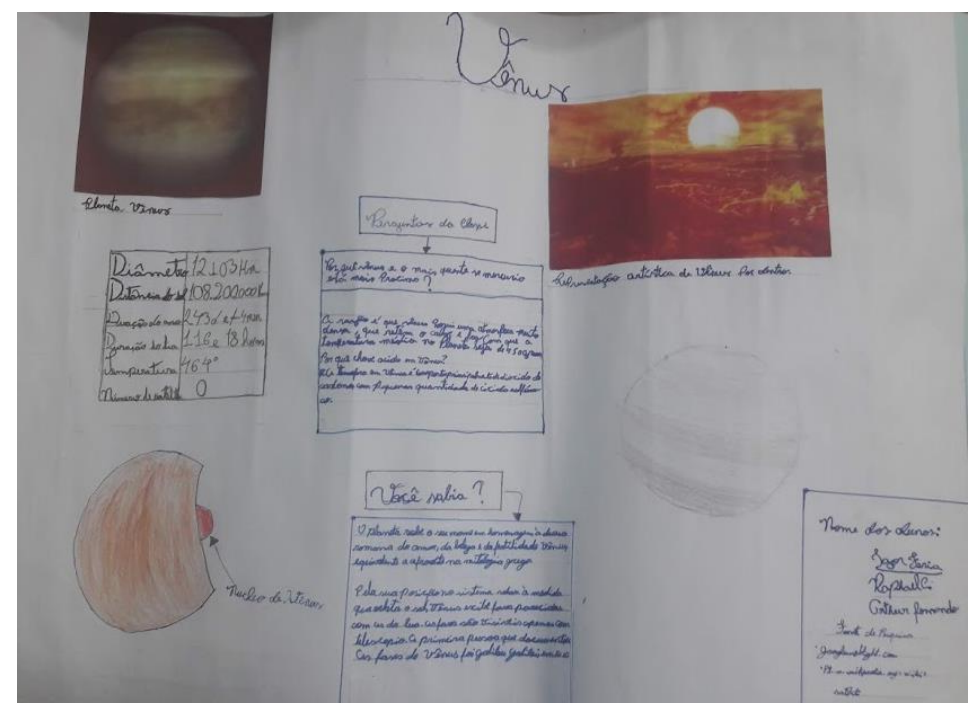

Figura 106 - Cartaz Vênus

O grupo que realizou a pesquisa sobre Mercúrio se dedicou em trazer imagens e boas respostas. Não conseguiram responder a todas as questões, mas se organizaram para realizar uma boa apresentação para a turma (Figura 107).

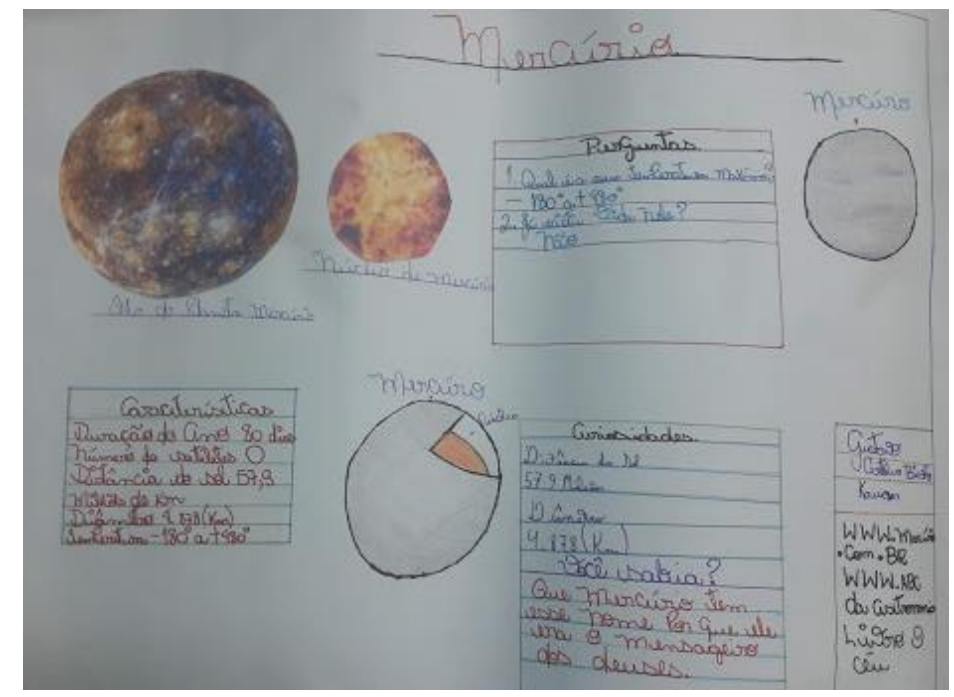

Figura 107 - Cartaz Mercúrio

Devido a nem todos os grupos terem conseguido responder as questões elaboradas, foi sugerido que eles escolhessem uma ou duas questões para responder. Mais adiante os estudantes teriam a oportunidade de realizar outras atividades que poderiam responder a algumas destas perguntas, entretanto na reelaboração da SD será necessário repensar uma estratégia que possa efetivar que as perguntas dos estudantes sejam respondidas.

Ao final da apresentação dos cartazes os alunos deveriam se autoavaliar, refletindo sobre sua participação na realização do trabalho em grupo e procurando 
explicar informações que aprenderam com a atividade. O resultado foi positivo, porque apesar das respostas não terem sido completamente formuladas, é possível observar que os estudantes aprenderam novas informações. A seguir selecionamos alguns depoimentos:

Aluno 4: "O planeta que eu escolhi foi Saturno e descobri que a lua de Saturno mais conhecida é Titâ";

Aluno 16: "Que os planetas não têm vida só na Terra e o meu planeta era o Plutão e eu curti muito essa atividade, Plutão virou um planeta anão!";

Aluno 19: "Eu aprendi sobre o diâmetro de Vênus e a distância do Sol e a temperatura e a rotação";

Aluno 21: "Que o Saturno é o $2^{\circ}$ maior planeta, que ele tem 62 luas";

Aluno 28: "Eu aprendi que eu não sabia que tinha montanhas, que existia umidade em Plutão e os dias de rotação são de 6,4 dias".

Por meio destes depoimentos constata-se a aprendizagem de novas informações, mas principalmente que os alunos estão aprendendo a identificar quando aprendem, como aprendem e o que fizeram para aprender.

A atividade final proposta na aula 11 era desenhar o que os estudantes aprenderam durante a aula sobre os tamanhos proporcionais dos planetas. Entregaram a atividade 28 alunos. Nas figuras 108 a 114 apresentam-se alguns desenhos confeccionados:

Observa-se na figura 108 que o estudante desenhou o Sol maior que todos os planetas, desenhou os oito planetas que pertencem ao Sistema Solar. O estudante se preocupou em pinta-los com suas cores correspondentes, desenhou Júpiter maior que os outros planetas, mas não fez o mesmo com os outros, mantendo-os com tamanhos semelhantes. 


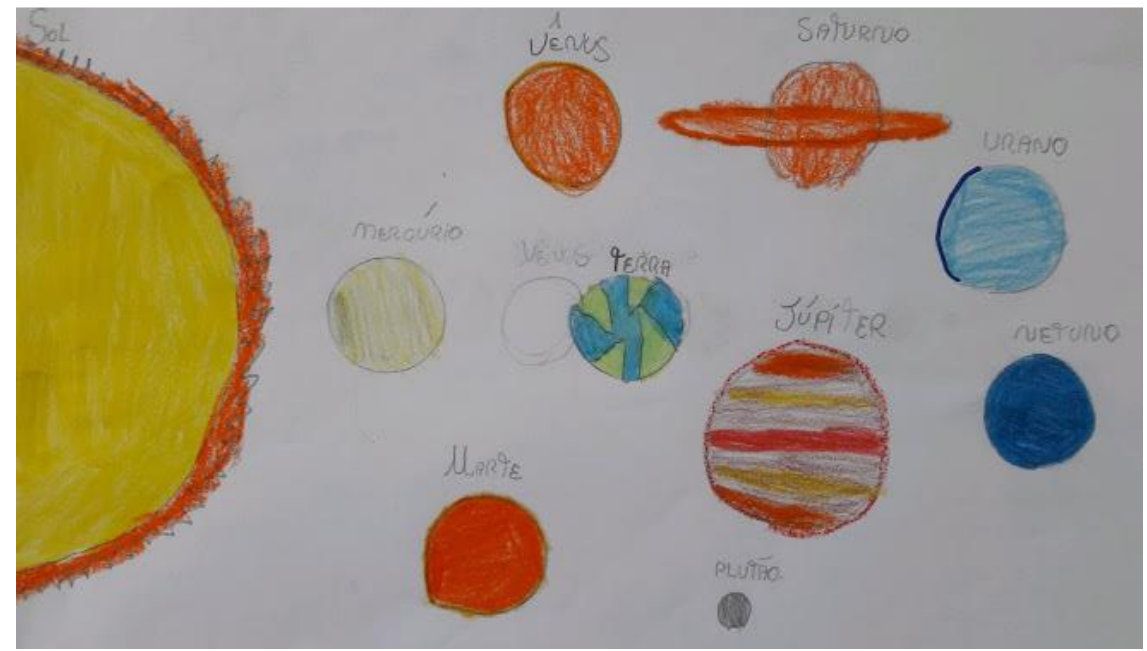

Figura 108 - Desenho dos planetas

O desenho da figura 109 apresenta o Sol como maior que todos os planetas. Entretanto é possível notar que o estudante não teve a mesma preocupação ao desenhar os planetas. É possível identificar a Terra no desenho, mas não na ordem adequada. Mesmo após a aula o estudante ainda desenhou os planetas enfileirados.

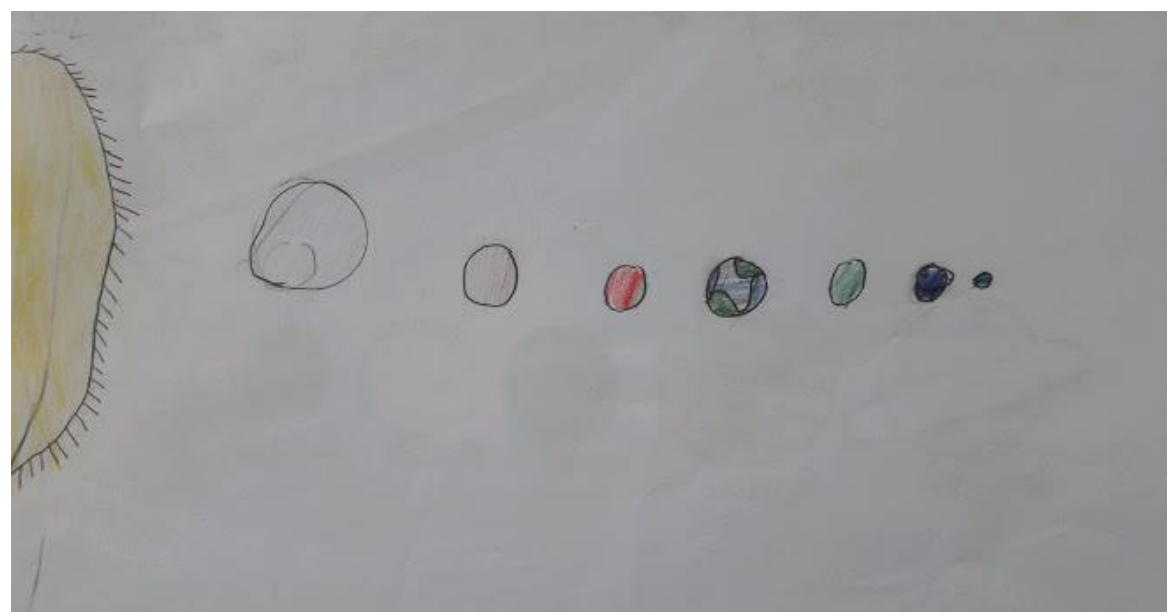

Figura 109 - Desenho dos planetas

Observamos na figura 110 que o aluno procurou representar o Sol maior que os planetas e que Júpiter e Saturno estão maiores que a Terra, por exemplo. Nota-se no desenho algumas características dos planetas, entretanto permanecem alinhados conforme as figuras apresentadas nos livros didáticos. Faltam na imagem Marte, Urano e Netuno. 


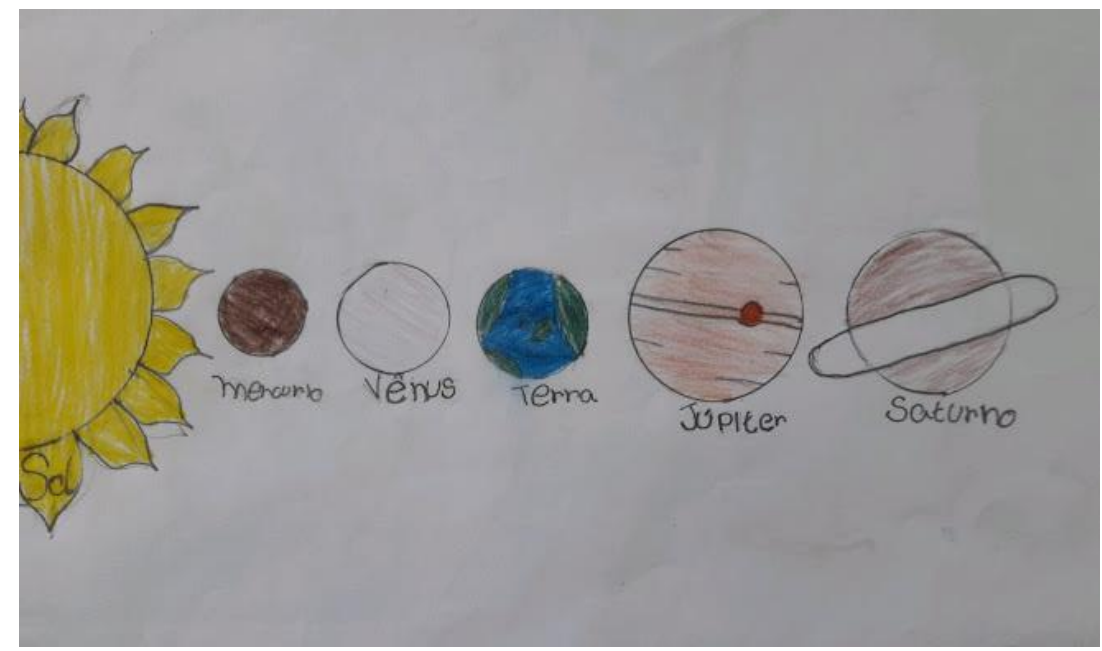

Figura 110 - Desenho dos planetas

$\mathrm{Na}$ figura 111 nota-se a representação do Sol como um astro maior que os demais planetas. Os planetas estão em ordem, mas não alinhados. E aparece outro elemento, o cinturão de asteroides.

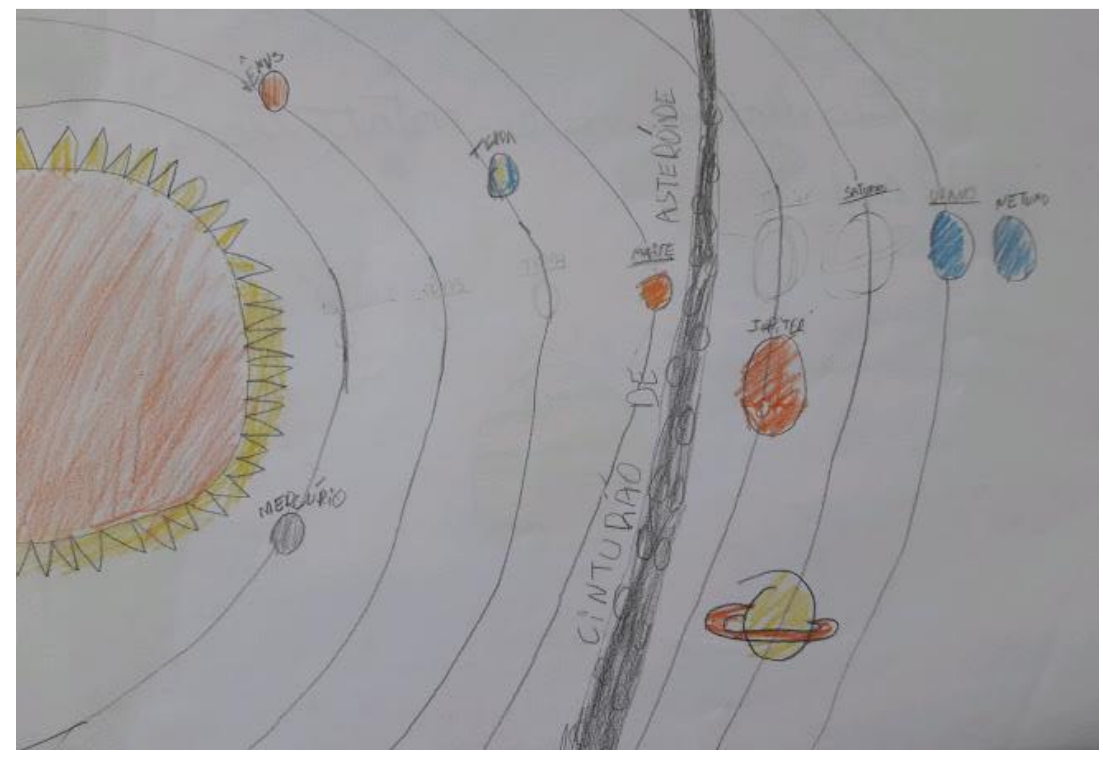

Figura 111 - Desenho dos planetas

A figura 112 apresenta todos os planetas do Sistema Solar em ordem a partir do Sol, mas não alinhados. Nota-se que o Sol está maior que os demais planetas, e entre os planetas observa-se também diferença de tamanho, percebe-se que Mercúrio é o menor, seguido de Vênus e Terra com tamanho semelhante e Marte menor. Os planetas gasosos também apresentam diferenças de tamanhos entre si. A disposição de cores também revela que o estudante já conhece mais características dos planetas. 


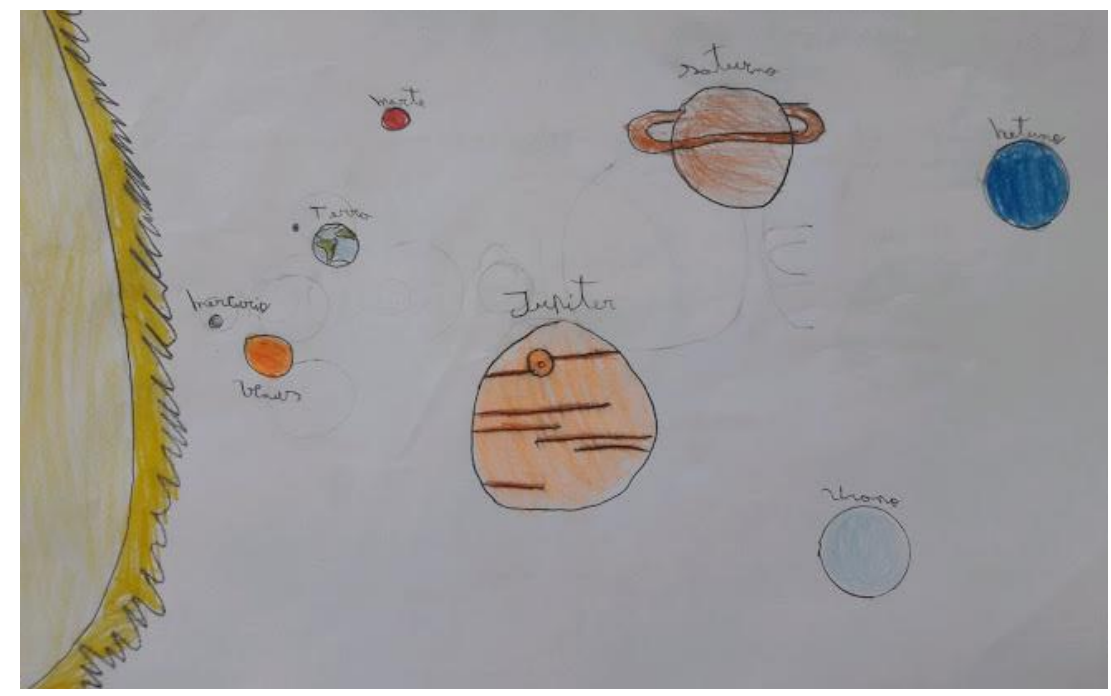

Figura 112 - Desenho dos planetas

A figura 113 revela o Sol no centro do Sistema Solar, maior que os demais planetas. O interessante é que eles não aprecem alinhados. Características sobre a cor foram cuidadosamente representadas no desenho.

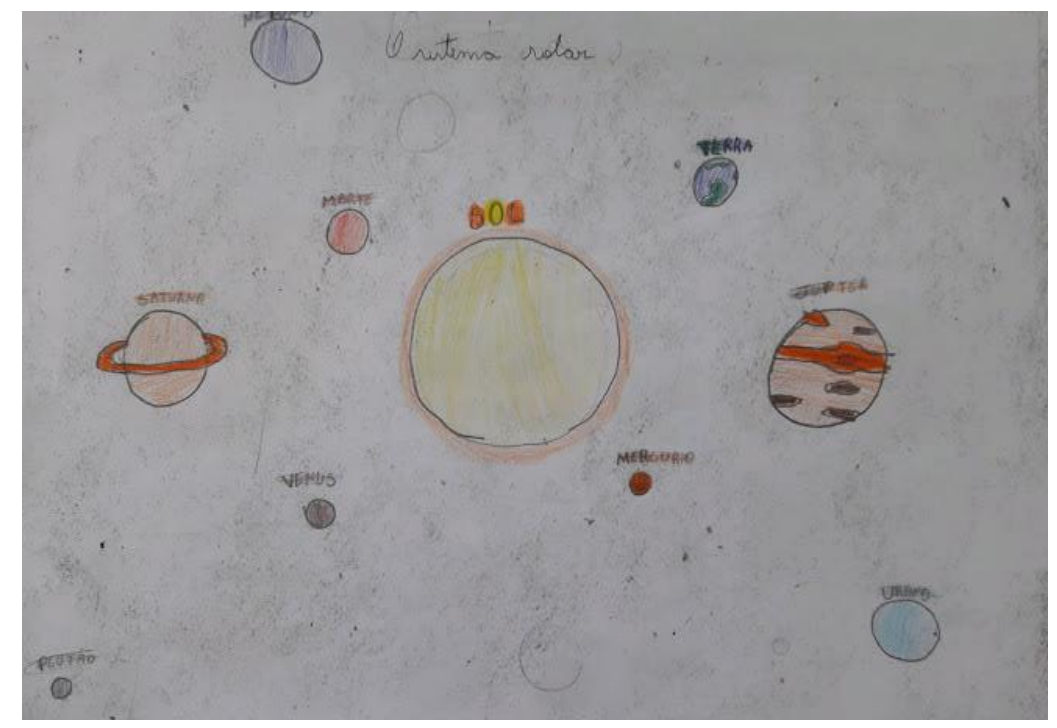

Figura 113 - Desenho dos planetas

A figura 114 apresenta o Sol maior que os demais planetas, alinhados. Mercúrio foi desenhado maior que os planetas terrestres, mas notamos uma preocupação do estudante em representar a proporção adequada. 


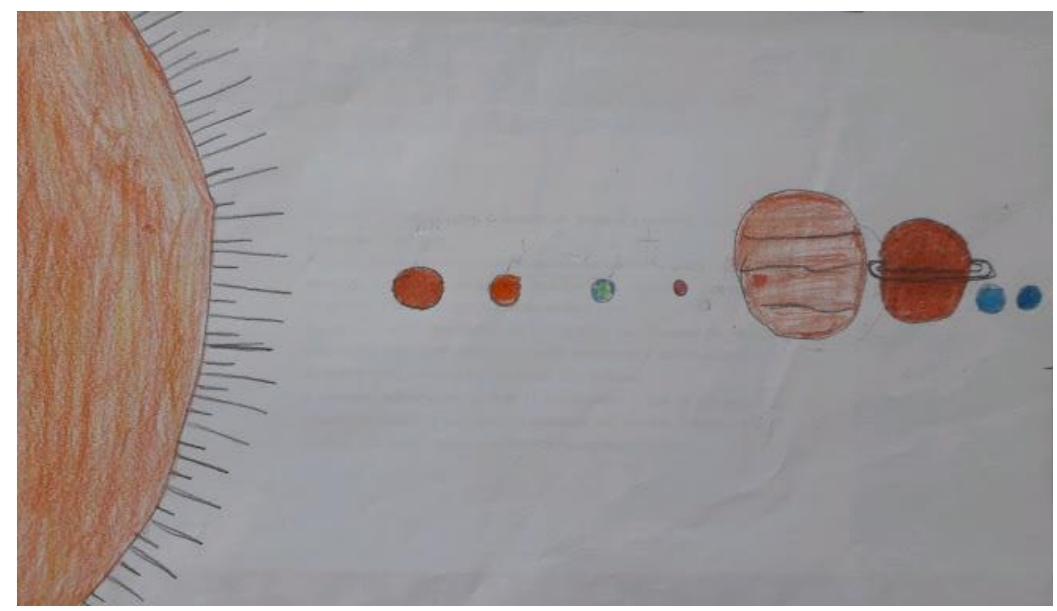

Figura 114 - Desenho dos planetas

A atividade proposta ao final da aula 12 era que os estudantes explicassem 0 tamanho e as distâncias dos planetas. Contamos com a devolutiva de 28 estudantes, e a seguir seleciona-se algumas frases:

Aluno 14: "Acho que você pensa que os planetas são todos juntos, mais não são, pelo contrário são bem distantes, o tamanho também muda muito";

Aluno 5: "Que os planetas não ficam em linha reta e alguns planetas são pequenos e os outros não, e a distância dos planetas são muito grandes";

Aluno 12: "Eu faria uma maquete para entender e iria falar que quando ele for desenhar para ele fazer planetas mais não tão distantes para caber todos os planetas e também colocar os planetas numa esfera e espalhados";

Aluno 24: "Eu diria que os planetas são bem maiores do que você pensa e a distância deles entre o Sol é bem longe é de bilhões e milhões";

Aluno 27: "Que os planetas não ficam alinhados ficam separados e cada um tem o seu diâmetro e os seus quilômetros até o Sol".

Aluno 3: "Eu falaria que um planeta não fica em alinhamento. É bem difícil. É também que é muita distância a deles. O tamanho deles não é igual e tem muita diferença de Júpiter para Plutão".

Aluno 7: "Eu ia falar que as distâncias não é grudado, é só usar a régua e medir como se fosse o tamanho em quilômetros e o tamanho do planeta é só usar o cm".

Pelas frases dos estudantes podemos identificar que os tamanhos e distâncias dos planetas chamaram a atenção, mas eles ainda apresentam dúvidas para explicar o que aprenderam. Seu conhecimento precisa de aprofundamento e vivenciar mais situações que os faça refletir e repensar. 
5.4 - O questionário final e os desenhos

Ao término das atividades desenvolvidas por meio da SD, os estudantes receberam um novo questionário, idêntico ao do início, para responderem novamente. A proposta era identificar o aprendizado dos alunos no decorrer destas aulas e se os objetivos foram alcançados. Além disso, também os desenhos produzidos no início foram devolvidos aos estudantes para que eles pudessem observar suas produções e refletirem sobre o que mudariam agora, ao finalizar a SD. É importante salientar que no primeiro questionário contamos com a participação de 28 estudantes, e no questionário final com a participação de 27 estudantes.

A primeira questão "O que é o Universo? Como ele surgiu?" foi dividida novamente em questão 1a e 1b. Apresenta-se na tabela 11 os resultados:

\begin{tabular}{|l|c|c|l|c|c|}
\hline \multicolumn{5}{|c|}{ Questão 1a "O que é o Universo?" } \\
\hline Respostas & $\begin{array}{c}\text { Número de } \\
\text { alunos }\end{array}$ & $\%$ & Respostas & $\begin{array}{c}\text { Número de } \\
\text { alunos }\end{array}$ & $\%$ \\
\hline Correta & 2 & $7,1 \%$ & Correta & 9 & $33,3 \%$ \\
\hline Parcial & 19 & $67,9 \%$ & Parcial & 12 & $44,4 \%$ \\
\hline Incorreta & 3 & $10,7 \%$ & Incorreta & 1 & $3,7 \%$ \\
\hline Não respondeu & 4 & $14,3 \%$ & Não respondeu & 5 & $18,5 \%$ \\
\hline
\end{tabular}

Tabela 11 - Comparativo da questão 1 a antes e depois da SD

Pode-se observar um aumento nos acertos dos estudantes ao explicarem o que é o Universo, entretanto $44,4 \%$ respondeu à questão de forma parcial, citando alguns astros como planetas ou o Sol como os constituintes do Universo. Por meio das respostas foi possível identificar que alguns estudantes conceituam Universo como sendo a Via Láctea ou o Sistema Solar, devido ao seu tamanho. Na SD não foram mencionados os termos energia ou matéria escura, e por este motivo, não se esperava que aparecesse esse tipo de resposta. Em alguns casos os estudantes erraram a questão porque não compreenderam a pergunta. 


\begin{tabular}{|l|c|c|l|c|c|}
\hline \multicolumn{5}{|c|}{ Questão 1b “Como o Universo surgiu?” } \\
\hline Respostas & $\begin{array}{c}\text { Número de } \\
\text { alunos }\end{array}$ & $\%$ & Respostas & $\begin{array}{c}\text { Número de } \\
\text { alunos }\end{array}$ & $\%$ \\
\hline Correta & 0 & $0 \%$ & Correta & 11 & $40,7 \%$ \\
\hline Parcial & 1 & $3,6 \%$ & Parcial & 2 & $7,4 \%$ \\
\hline Incorreta & 6 & $21,4 \%$ & Incorreta & 6 & $22,2 \%$ \\
\hline Não respondeu & 21 & $75,0 \%$ & Não respondeu & 8 & $29,6 \%$ \\
\hline
\end{tabular}

Tabela 12 - Comparativo da questão $1 b$ antes e depois da SD

Observa-se que nesta questão os estudantes ampliaram sua possibilidade de resposta, mencionando que a teoria do Big Bang é a mais aceita para explicar a origem do Universo. Os alunos que conseguiram explicar essa questão subiram de $0 \%$ para $40,7 \%$. Entretanto, há estudantes que ainda não conseguiram explicar a teoria, respondendo incorretamente a pergunta.

Os resultados da questão 2 "O que é o Sistema Solar? Como ele é formado?" estão apresentados na tabela 13:

\begin{tabular}{|l|c|c|l|c|c|}
\hline \multicolumn{4}{|c|}{ Questão 2 "O que é o Sistema Solar? Como ele é formado? } \\
\hline \multicolumn{4}{|c|}{ Questionário inicial } & \multicolumn{3}{c|}{ Questionário Final } \\
\hline Respostas & $\begin{array}{c}\text { Número de } \\
\text { alunos }\end{array}$ & $\%$ & Respostas & $\begin{array}{c}\text { Número de } \\
\text { alunos }\end{array}$ & $\%$ \\
\hline Correta & 0 & $0,0 \%$ & Correta & 0 & $0,0 \%$ \\
\hline Parcial & 8 & $28,6 \%$ & Parcial & 22 & $81,5 \%$ \\
\hline Incorreta & 12 & $42,9 \%$ & Incorreta & 5 & $18,5 \%$ \\
\hline Não respondeu & 8 & $28,6 \%$ & Não respondeu & 0 & $0,0 \%$ \\
\hline
\end{tabular}

Tabela 13 - Comparativo da questão 2 antes e depois da SD

A princípio ao observar-se os resultados da resposta à esta questão parece que se obteve pouco avanços, pois nenhuma resposta foi considerada como correta. $\mathrm{Na}$ verdade, os alunos obtiveram ótimos avanços na definição do que é o Sistema Solar e como ele é formado, mas nenhum aluno conseguiu expandir a constituição do Sistema Solar como um local que abriga o Sol, com os planetas e outros astros girando ao seu redor. Por este motivo, tivemos que classificar as respostas como parciais. Consideraram-se como respostas incorretas a citação de estrelas (além do sol) ou apenas Sol-Terra-Lua como pertencente ao Sistema Solar.

Apresentam-se nas figuras 115 a 119 algumas das respostas consideradas parciais, que nos faz concluir que os estudantes já revelam um bom avanço nessa 
compreensão, mas que seriam necessárias mais algumas aulas para que pudessem ser capazes de responder a esta questão de acordo com nossa expectativa.

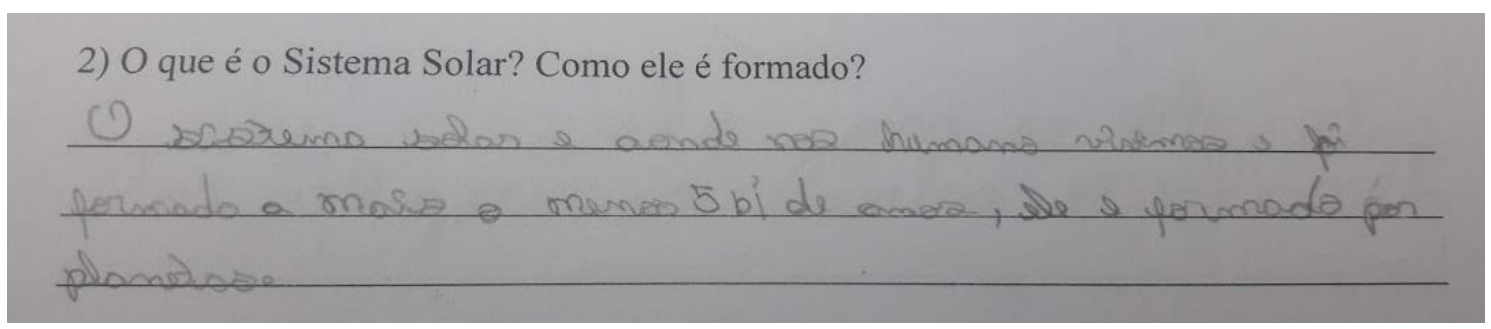

Figura 115 - Resposta questão 2 após a SD

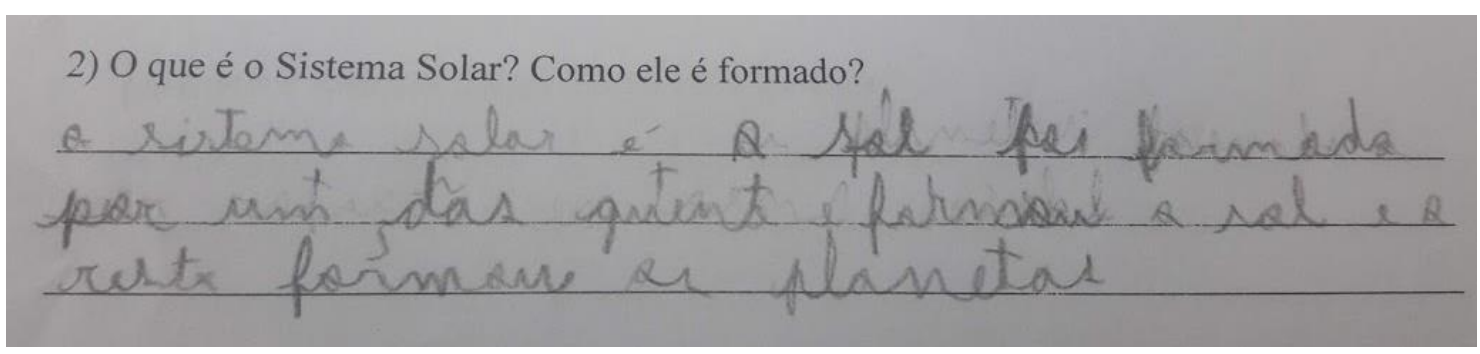

Figura 116 - Resposta questão 2 após a SD

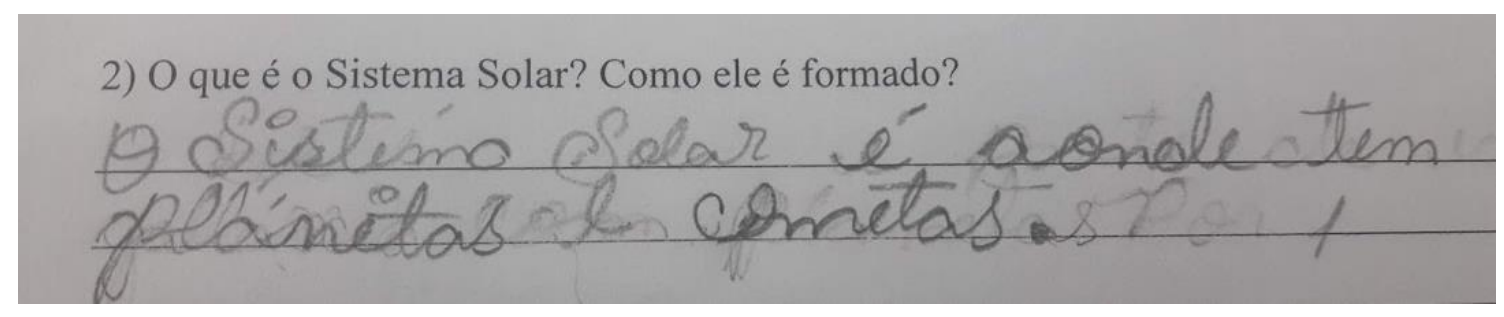

Figura 117 - Resposta questão 2 após a SD

2) O que é o Sistema Solar? Como ele é formado?

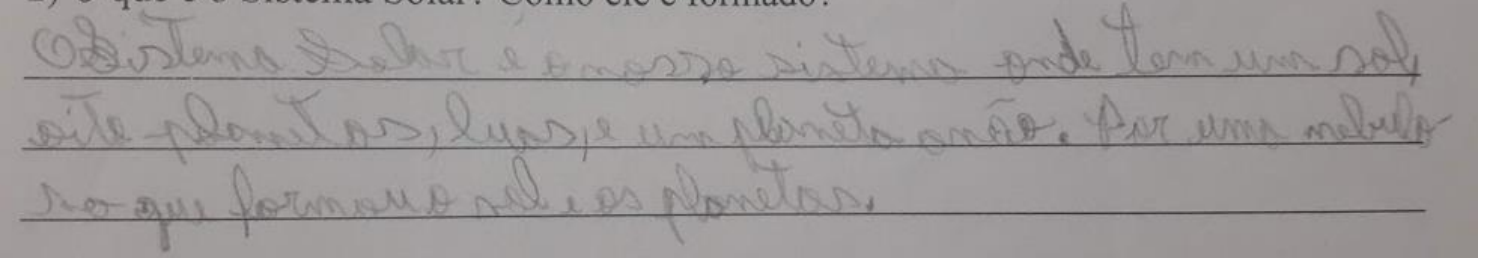

Figura 118 - Resposta questão 2 após a SD

2) O que é o Sistema Solar? Como ele é formado?

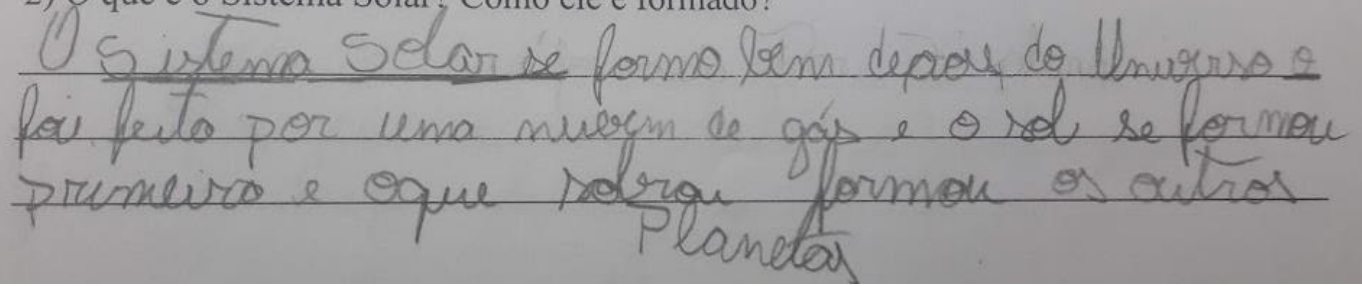

Figura 119 - Resposta questão 2 após a SD 
$\mathrm{Na}$ questão 3, apesar da pergunta ser aberta, procurou-se considerar a resposta correta quando os estudantes citaram todos os oito planetas pertencentes ao Sistema Solar (Mercúrio, Vênus, Terra, Marte, Júpiter, Saturno, Urano e Netuno). As respostas consideradas incorretas ocorreram quando o aluno citou a Lua, o Sol ou outros astros que não são os planetas para a composição da resposta. Observa-se um grande avanço dos estudantes na identificação dos planetas pertencentes ao Sistema Solar (Tabela 14).

\begin{tabular}{|l|c|c|c|c|c|}
\hline \multicolumn{5}{|c|}{ Questão 3 “Quais planetas você conhece?” } \\
\hline \multicolumn{3}{|c|}{ Questionário inicial } & \multicolumn{3}{c|}{ Questionário Final } \\
\hline Respostas & $\begin{array}{c}\text { Número de } \\
\text { alunos }\end{array}$ & $\%$ & Respostas & $\begin{array}{c}\text { Número de } \\
\text { alunos }\end{array}$ & $\%$ \\
\hline Correta & 1 & $3,6 \%$ & Correta & 17 & $63,0 \%$ \\
\hline Parcial & 13 & $46,4 \%$ & Parcial & 6 & $22,2 \%$ \\
\hline Incorreta & 14 & $50,0 \%$ & Incorreta & 4 & $14,8 \%$ \\
\hline Não respondeu & 0 & $0 \%$ & Não respondeu & 0 & $0 \%$ \\
\hline
\end{tabular}

Tabela 14 - Comparativo da questão 3 antes e depois da SD

O resultado da questão 4 demonstra que a turma conseguiu aprender que na lista proposta o Sol é o maior astro (Tabela 15). Na questão proposta no início da SD os alunos escolheram Marte como o astro maior nessa mesma lista.

\begin{tabular}{|l|c|c|c|c|c|}
\hline \multicolumn{4}{|c|}{ Questão 4- Quem é maior que a Terra? - Lua, Sol ou Marte" } \\
\hline \multicolumn{4}{|c|}{ Questionário inicial } & \multicolumn{3}{c|}{ Questionário Final } \\
\hline Respostas & $\begin{array}{c}\text { Número de } \\
\text { alunos }\end{array}$ & $\%$ & Respostas & $\begin{array}{c}\text { Número de } \\
\text { alunos }\end{array}$ & $\%$ \\
\hline Correta & 13 & $46,4 \%$ & Correta & 27 & $100 \%$ \\
\hline Incorreta & 15 & $54 \%$ & Incorreta & 0 & $0 \%$ \\
\hline Não respondeu & 0 & $0 \%$ & Não respondeu & 0 & $0 \%$ \\
\hline
\end{tabular}

Tabela 15 - Comparativo da questão 4 antes e depois da SD

Na questão 5 conseguimos verificar também que os alunos aprenderam que o Sol é maior que a Lua (Tabela 16). A questão no início do projeto já tinha mostrado bons acertos. 


\begin{tabular}{|l|c|c|l|c|c|}
\hline \multicolumn{5}{|c|}{ Questão 5 “Quem é maior? - Sol ou Lua?" } \\
\hline \multicolumn{3}{|c|}{ Questionário inicial } & \multicolumn{3}{c|}{ Questionário Final } \\
\hline Respostas & $\begin{array}{c}\text { Número de } \\
\text { alunos }\end{array}$ & $\%$ & Respostas & $\begin{array}{c}\text { Número de } \\
\text { alunos }\end{array}$ & $\%$ \\
\hline Correta & 22 & $78,6 \%$ & Correta & 27 & $100 \%$ \\
\hline Incorreta & 6 & $21,4 \%$ & Incorreta & 0 & $0 \%$ \\
\hline Não respondeu & 0 & $0 \%$ & Não respondeu & 0 & $0 \%$ \\
\hline
\end{tabular}

Tabela 16 - Comparativo da questão 5 antes e depois da SD

Os estudantes também compreenderam bem a diferença de tamanhos entre Terra-Sol-Lua, pelas respostas obtidas à questão 6 (Tabela 17). Os estudantes possivelmente podem imaginar que a Terra é maior devido estarem dentro dela, e ela ser grande e o Sol parecer pequeno visto do céu.

\begin{tabular}{|l|c|c|l|c|c|}
\hline \multicolumn{4}{|c|}{ Questão 6 “Quem é maior? - Terra, Sol ou Lua?” } \\
\hline \multicolumn{3}{|c|}{ Questionário inicial } & \multicolumn{3}{c|}{ Questionário Final } \\
\hline Respostas & $\begin{array}{c}\text { Número de } \\
\text { alunos }\end{array}$ & $\%$ & Respostas & $\begin{array}{c}\text { Número de } \\
\text { alunos }\end{array}$ & $\%$ \\
\hline Correta & 16 & $57 \%$ & Correta & 26 & $96,3 \%$ \\
\hline Incorreta & 12 & $43 \%$ & Incorreta & 1 & $3,7 \%$ \\
\hline Não respondeu & 0 & $0 \%$ & Não respondeu & 0 & $0 \%$ \\
\hline
\end{tabular}

Tabela 17 - Comparativo da questão 6 antes e depois da SD

O resultado da questão 7 demonstra que os estudantes que responderam errado na primeira vez, em sua maioria conseguiram compreender que a Terra está mais próxima da Lua, conforme mostra a tabela 18.

\begin{tabular}{|l|c|c|l|c|c|}
\hline \multicolumn{4}{|c|}{ Questão 7 "A Terra está mais próxima do... Sol ou da Lua?" } \\
\hline \multicolumn{3}{|c|}{ Questionário inicial } & \multicolumn{3}{c|}{ Questionário Final } \\
\hline Correta & $\begin{array}{c}\text { Número de } \\
\text { alunos }\end{array}$ & $\%$ & Respostas & $\begin{array}{c}\text { Número de } \\
\text { alunos }\end{array}$ & $\%$ \\
\hline Incorreta & 19 & $67,9 \%$ & Correta & 25 & $92,6 \%$ \\
\hline Não respondeu & 9 & $32,1 \%$ & Incorreta & 2 & $7,4 \%$ \\
\hline
\end{tabular}

Tabela 18 - Comparativo da questão 7 antes e depois da SD

Na questão 8 observa-se que os estudantes já conseguem responder melhor como ocorrem os dias e as noites, mas só foi considerada resposta correta quando os estudantes que além de nomearem o movimento de rotação conseguiram descrever 
o processo que o movimento causa no planeta, já que ao girar partes do planeta são iluminadas pelo Sol e gradativamente partes vão deixando de ser iluminadas, caracterizando as noites. Pouco mais da metade da turma, o equivalente a 55,5\% conseguiu explicar o processo de modo parcial (Tabela 19), mas já se observa um resultado melhor do que o obtido no primeiro questionário, quando os estudantes ainda apenas diziam que para existir noite e dia era só "aparecer o Sol ou a Lua".

\begin{tabular}{|l|c|c|l|c|c|}
\hline \multicolumn{5}{|c|}{ Questão 8 "Como ocorrem os dias e as noites?" } \\
\hline \multicolumn{3}{|c|}{ Questionário inicial } & \multicolumn{3}{c|}{ Questionário Final } \\
\hline Respostas & $\begin{array}{c}\text { Número de } \\
\text { alunos }\end{array}$ & $\%$ & Respostas & $\begin{array}{c}\text { Número de } \\
\text { alunos }\end{array}$ & $\%$ \\
\hline Correta & 1 & $3,6 \%$ & Correta & 5 & $18,5 \%$ \\
\hline Parcial & 11 & $39,3 \%$ & Parcial & 15 & $55,6 \%$ \\
\hline Incorreta & 15 & $53,6 \%$ & Incorreta & 7 & $25,9 \%$ \\
\hline Não respondeu & 1 & $3,6 \%$ & Não respondeu & 0 & $0,0 \%$ \\
\hline
\end{tabular}

Tabela 19 - Comparativo da questão 8 antes e depois da SD

Conclui-se que a SD obteve avanços nos resultados dos questionários, mas avalia-se que estes resultados poderiam melhorar. É o que apresentaremos no capítulo 6, ao reelaborar a Sequência Didática para deixa-la mais adequada aos nossos objetivos iniciais. Também é importante salientar que os desenhos realizados pelos estudantes nos revelam uma aprendizagem mais completa, pois em algumas situações a resposta de questionários podem ser causadas por má interpretação dos estudantes ou má formulação das perguntas. Apresentamos a comparação de alguns desenhos criados no início e fim deste processo pelos mesmos estudantes. Selecionamos apenas alguns para análise.

Observa-se na figura 120 que o aluno desenhou a Terra maior que o Sol e a Lua, e que Lua e Sol estão desenhados do mesmo tamanho. Isso nos revela que o estudante antes de iniciar a SD, podia pensar que a Terra era maior do que o Sol e Lua, de acordo com as concepções alternativas. No desenho final, observa-se que o Sol é o maior astro, e depois a Terra e a Lua. 


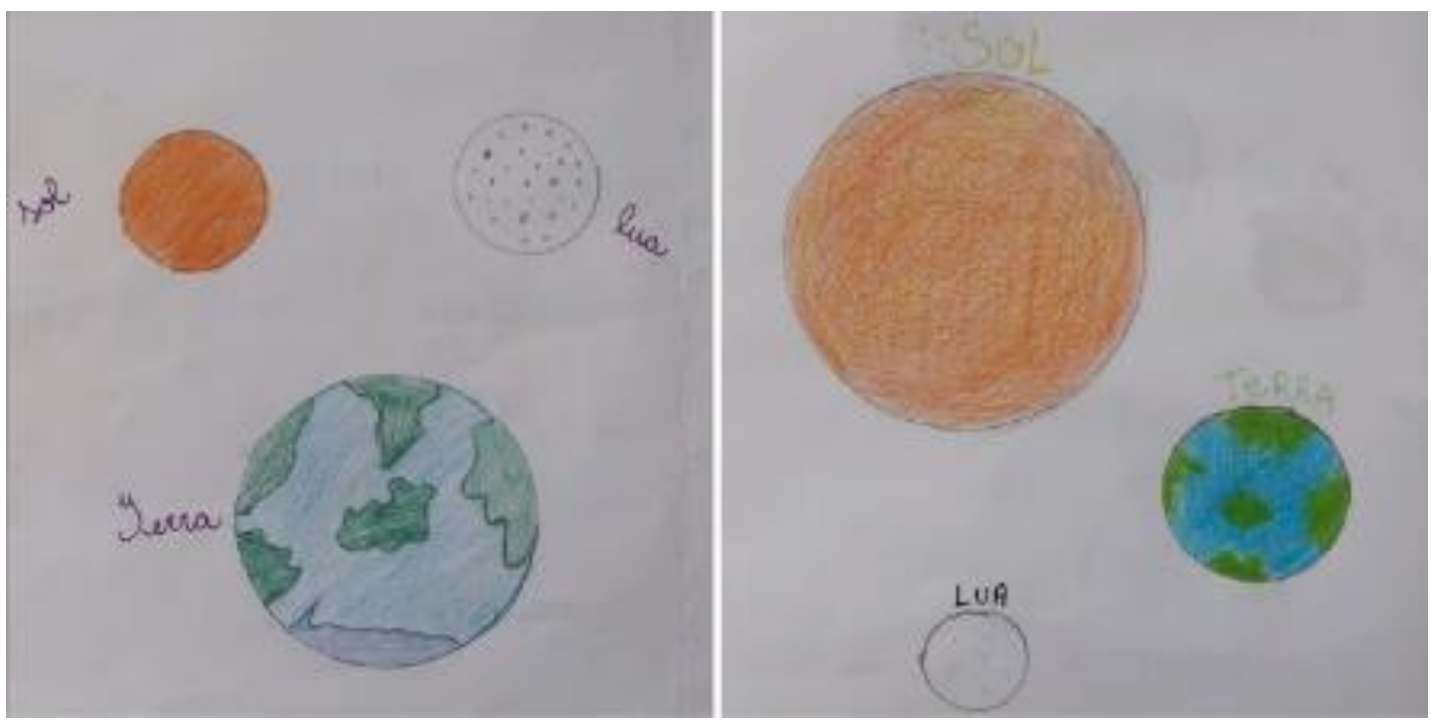

Figura 120 - Desenho antes e depois da SD (Terra-Sol-Lua)

Na figura 121 observa-se que o estudante já tinha o conhecimento prévio de que o Sol é o maior astro. Entretanto, em seu desenho final há uma mudança em relação a comparação do tamanho do Sol. Na segunda figura ele está muito maior e a Terra e a Lua ainda menores. Podemos concluir que a atividade prática sobre os tamanhos dos planetas em relação ao Sol fez o estudante rever sua aprendizagem inicial.

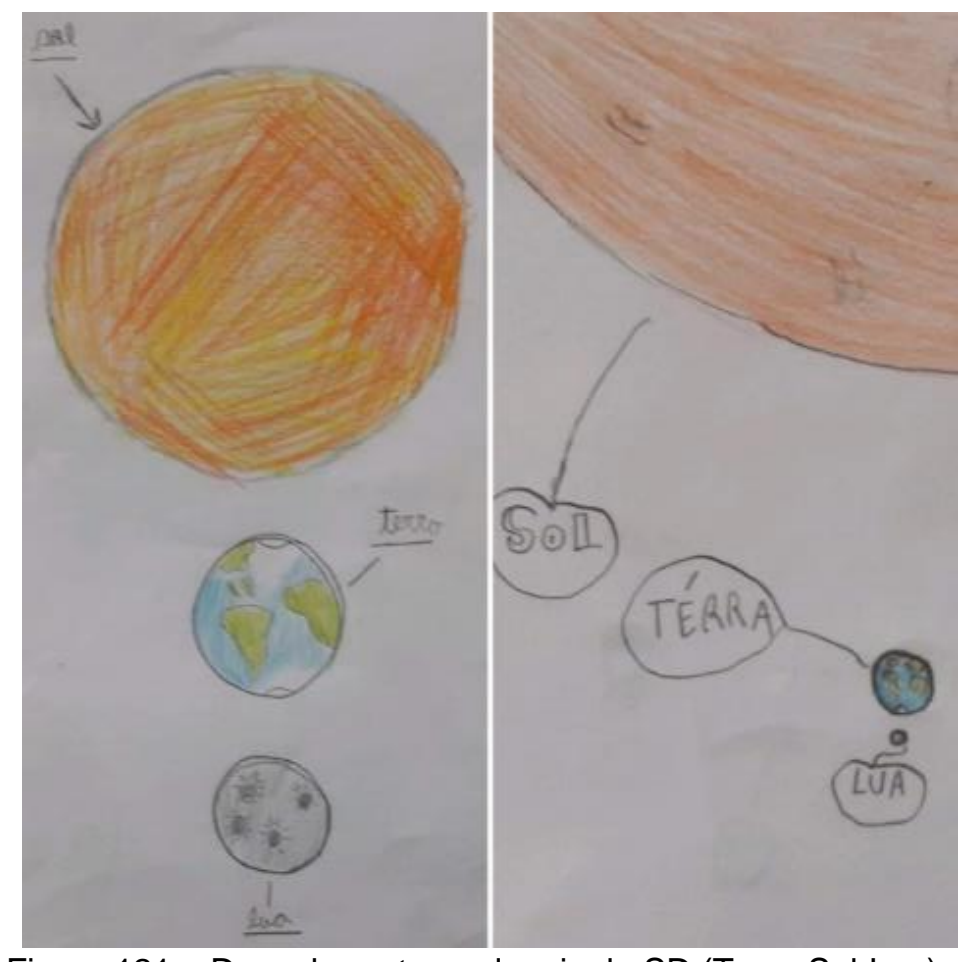

Figura 121 - Desenho antes e depois da SD (Terra-Sol-Lua) 
$\mathrm{Na}$ figura 122 mostra-se que desenho inicial o estudante representou os astros praticamente do mesmo tamanho, e o Sol e Lua estão um pouquinho maiores. No segundo desenho, é possível observar uma mudança total dos tamanhos. Conservase o alinhamento dos astros e raios no Sol.

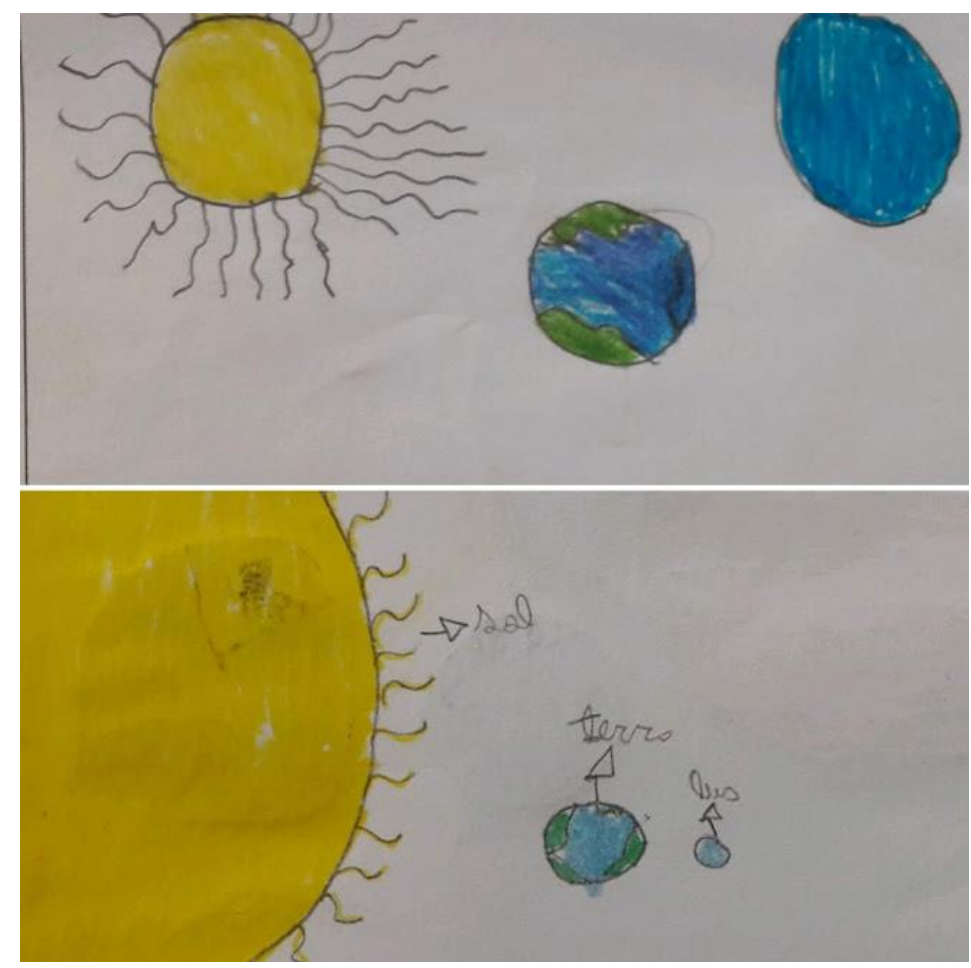

Figura 122 - Desenho antes e depois da SD (Terra-Sol-Lua)

$\mathrm{Na}$ Figura 123, observa-se que o estudante já apresentava o conhecimento prévio correto de que o Sol é maior, e depois Terra e Lua. Entretanto, no desenho final, o estudante diminui ainda mais a Terra e a Lua.

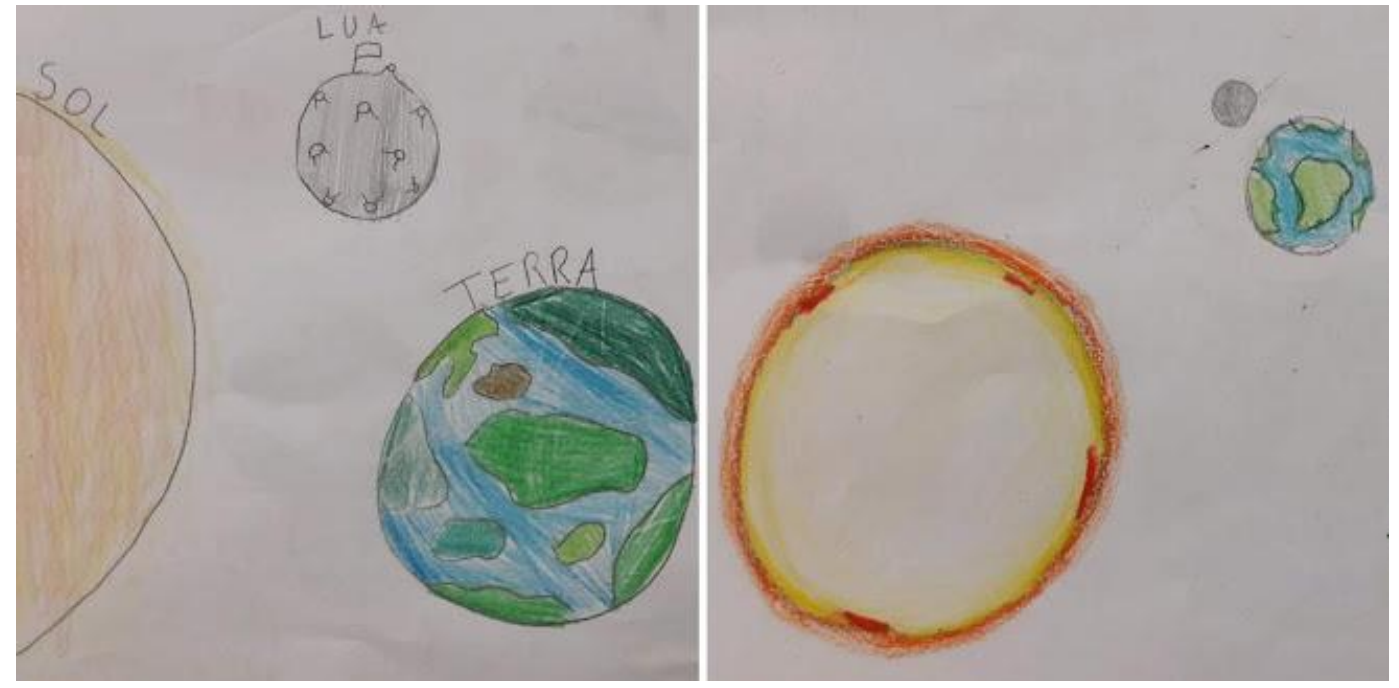

Figura 123 - Desenho antes e depois da SD (Terra-Sol-Lua) 
Na figura 124 o estudante faz os astros sem a preocupação com os tamanhos, e o que chama atenção no desenho é a conquista da Lua, pelos americanos. No desenho final, o estudante amplia o Sol. A Terra está um pouco menor que a Lua, mas a Lua está em destaque devido ao astronauta estar "pendurado" na bandeira. O interesse do estudante se revela sobre o encantamento humano pela conquista da Lua e o desbravamento das conquistas espaciais.

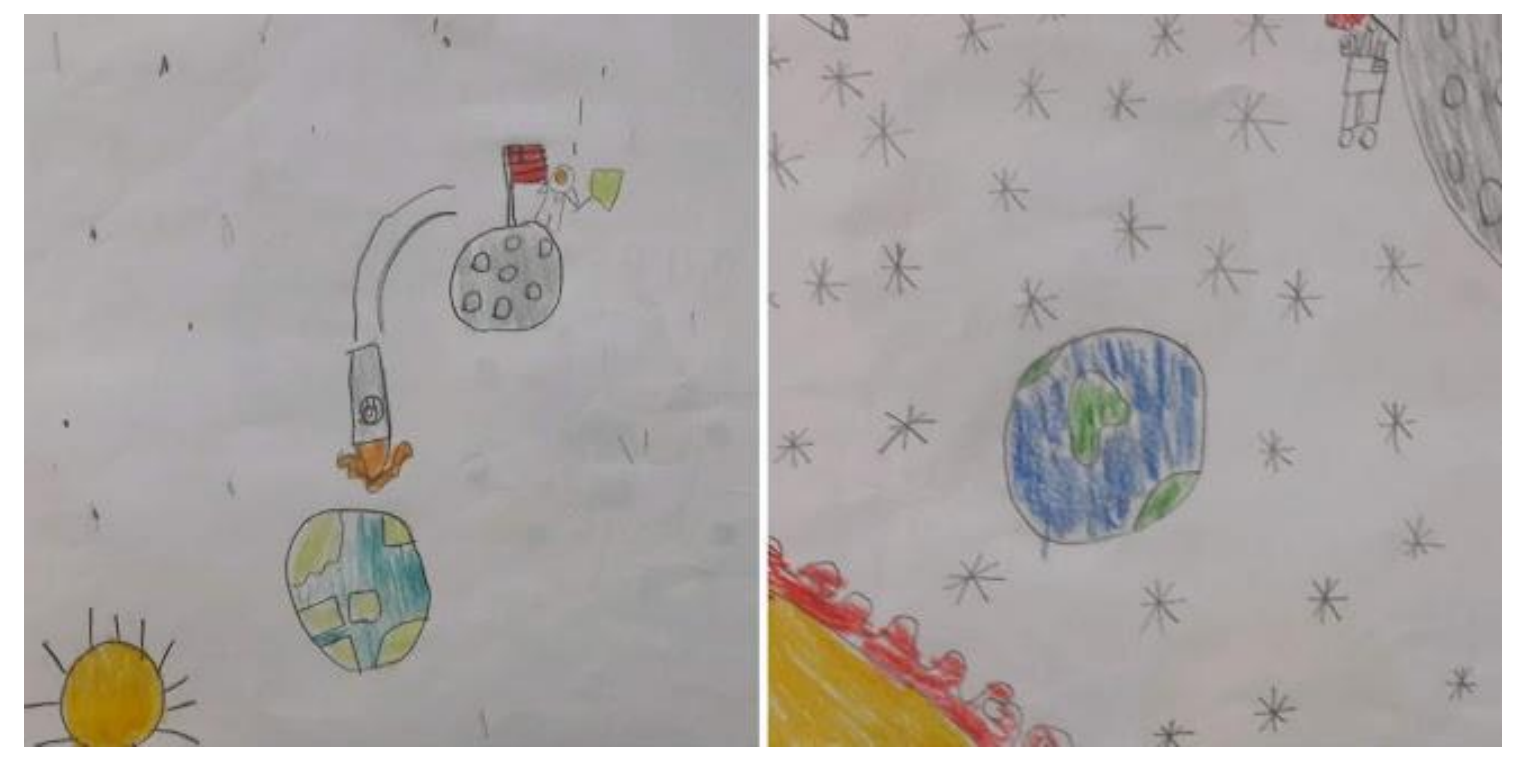

Figura 124 - Desenho antes e depois da SD (Terra-Sol-Lua)

Na figura 125 o aluno também já demonstra apresentar o conhecimento prévio do tamanho dos astros, no entanto, em eu desenho final ele realiza o ajuste do tamanho do Sol, procurando amplia-lo. Destaque para a Terra, com as calotas polares formadas. 


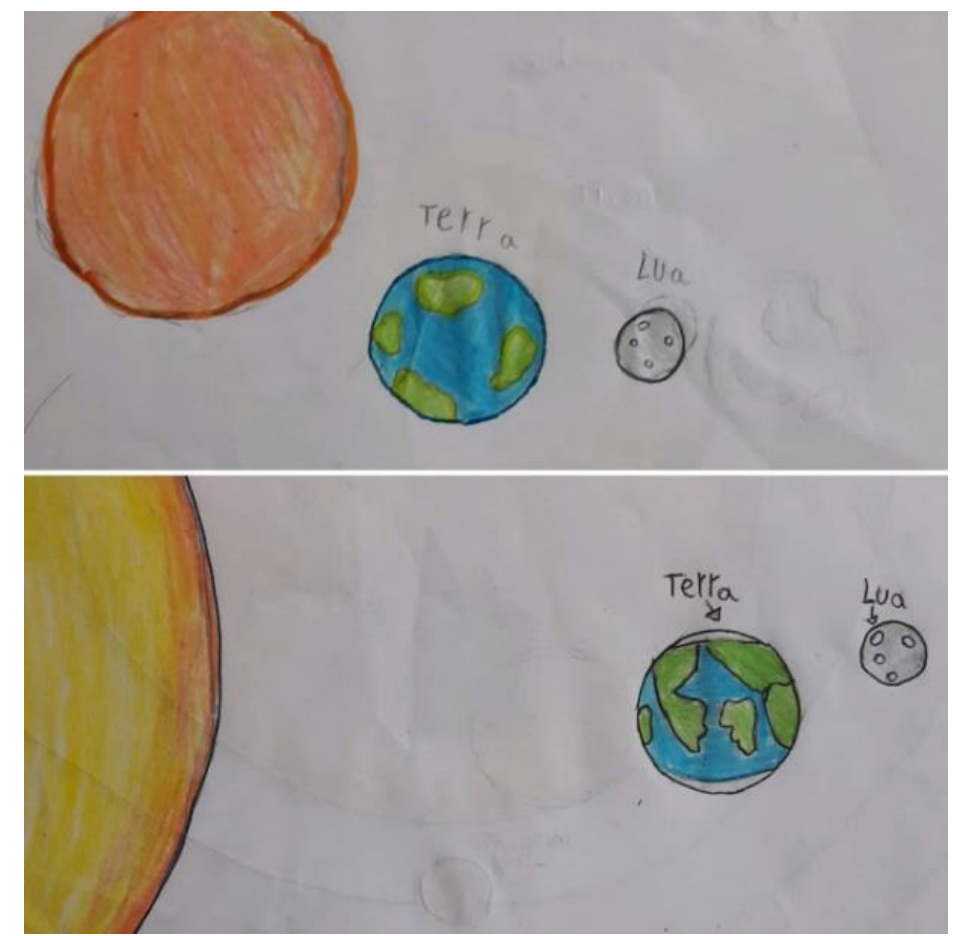

Figura 125 - Desenho antes e depois da SD (Terra-Sol-Lua)

Na Figura 126 observa-se no desenho inicial que o estudante desenhou além da Terra-Sol-Lua outros astros. Em seu desenho final, observamos uma mudança no que diz respeito aos tamanhos dos astros, e apresentação de uma fase da Lua (quarto crescente).

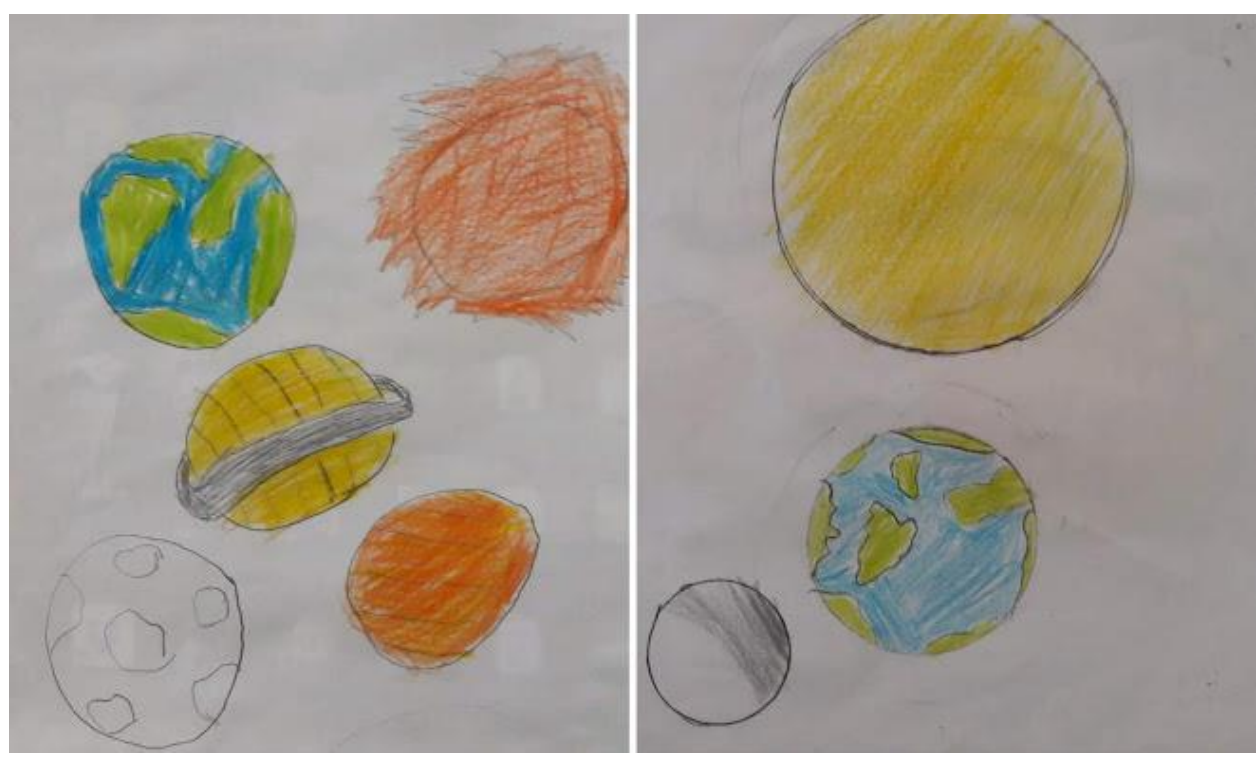

Figura 126 - Desenho antes e depois da SD (Terra-Sol-Lua) 
A evolução do desenho da figura 127 nos remete também que o estudante vê como marcante a diferença de tamanhos entre os astros, e a Lua se revela como muito pequena em relação ao tamanho da Terra.
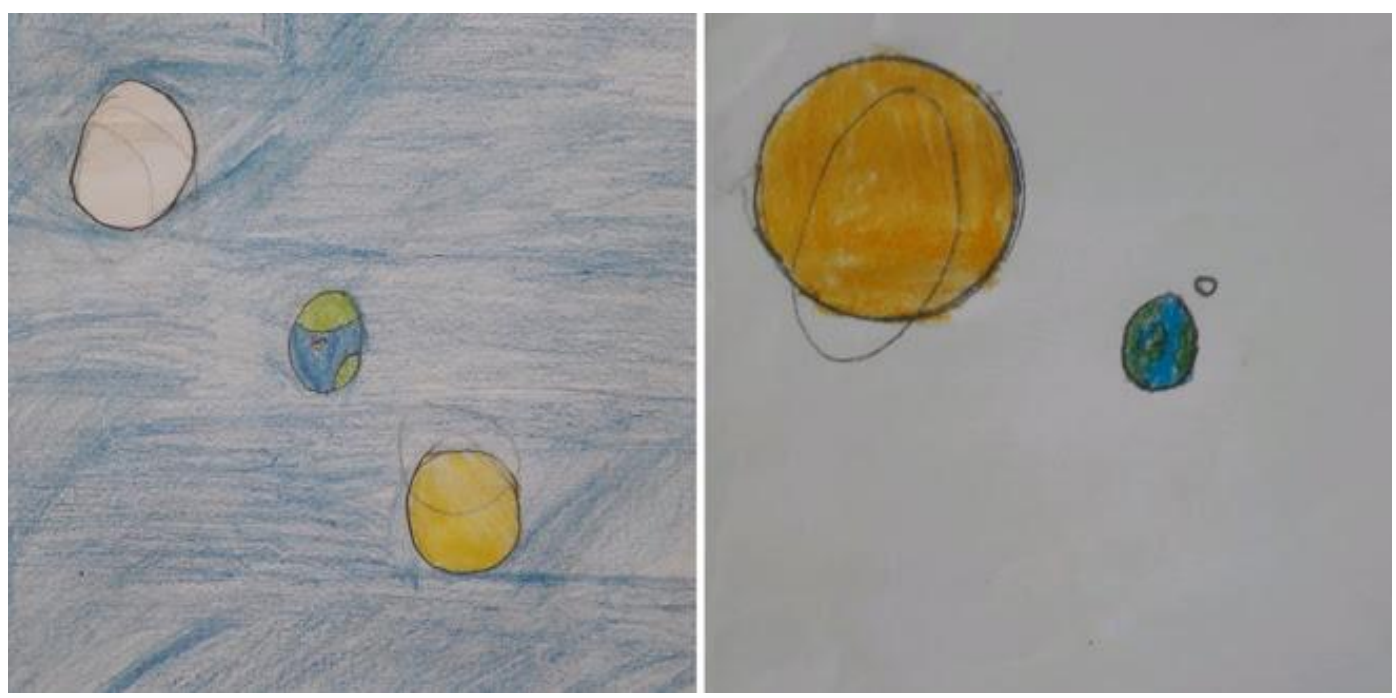

Figura 127 - Desenho antes e depois da SD (Terra-Sol-Lua)

Na figura 128, observa-se no desenho inicial que Sol -Terra foram desenhados do mesmo tamanho e a Lua um pouco menor. No desenho final, já observamos uma progressiva mudança com o Sol, maior que os demais astros.

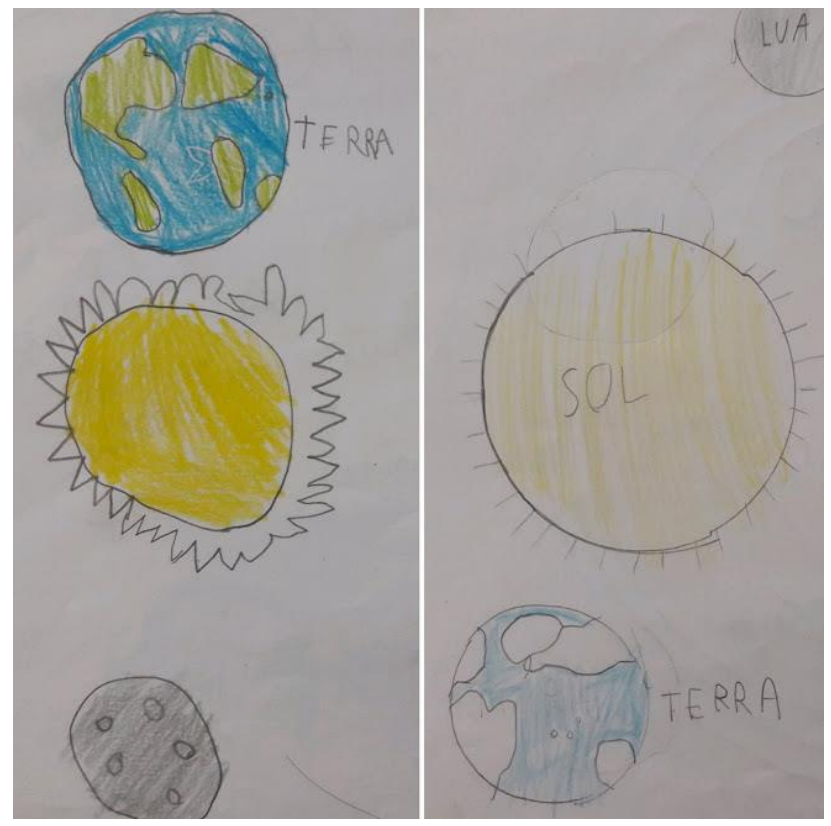

Figura 128 - Desenho antes e depois da SD (Terra-Sol-Lua) 
Nas figuras 129 a 132 observamos alguns desenhos sobre nossa localização no planeta. É interessante como os estudantes escolheram caminhos diversos para realizar estas representações.

Na figura 129 inicialmente o aluno representou o Brasil, como país e São Paulo como outro continente. No desenho final o estudante prefere desenhar o planeta com a localização do país no continente. Possivelmente, o contato com o globo terrestre pode ter auxiliado o estudante a replanejar seu desenho.

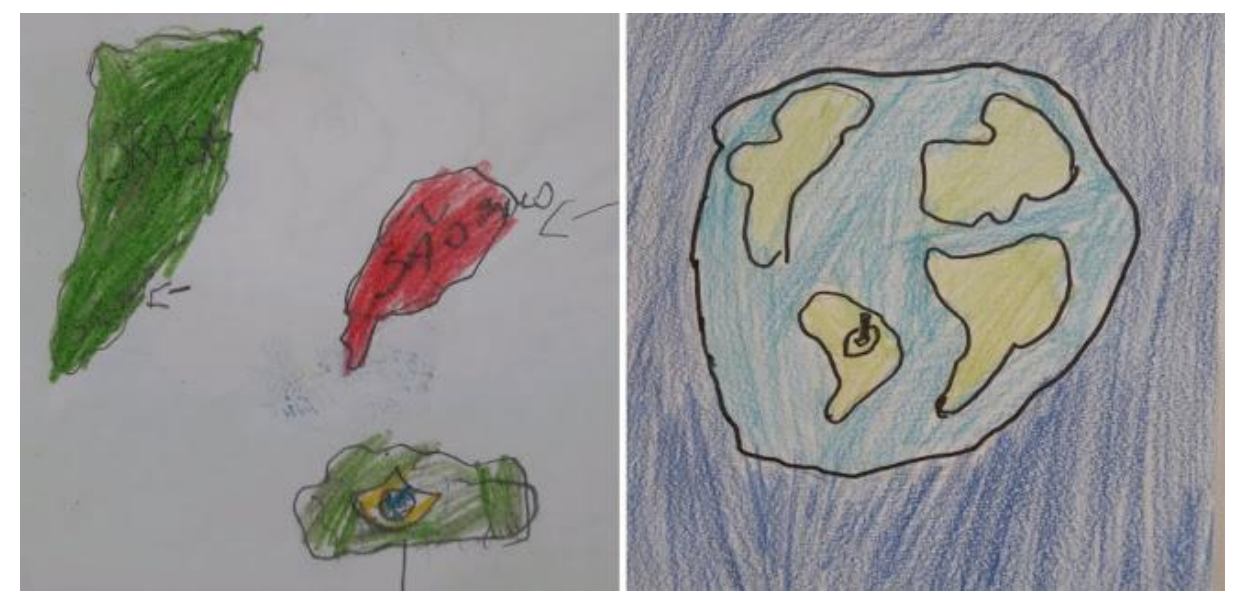

Figura 129 - Desenho antes e depois (Onde você está no planeta?)

Na figura 130 o estudante mostra em seu desenho a Terra, as calotas polares, mas não aponta sua localização. Ao rever seu desenho no final o aluno parte de São Paulo, até chegar a Via Láctea. É interessante observar o raciocínio do aluno ao compreender que nossa localização vai além do bairro, ou além das imediações do planeta. É uma possibilidade mais ampliada de abstrair o que aprendeu por meio das aulas.

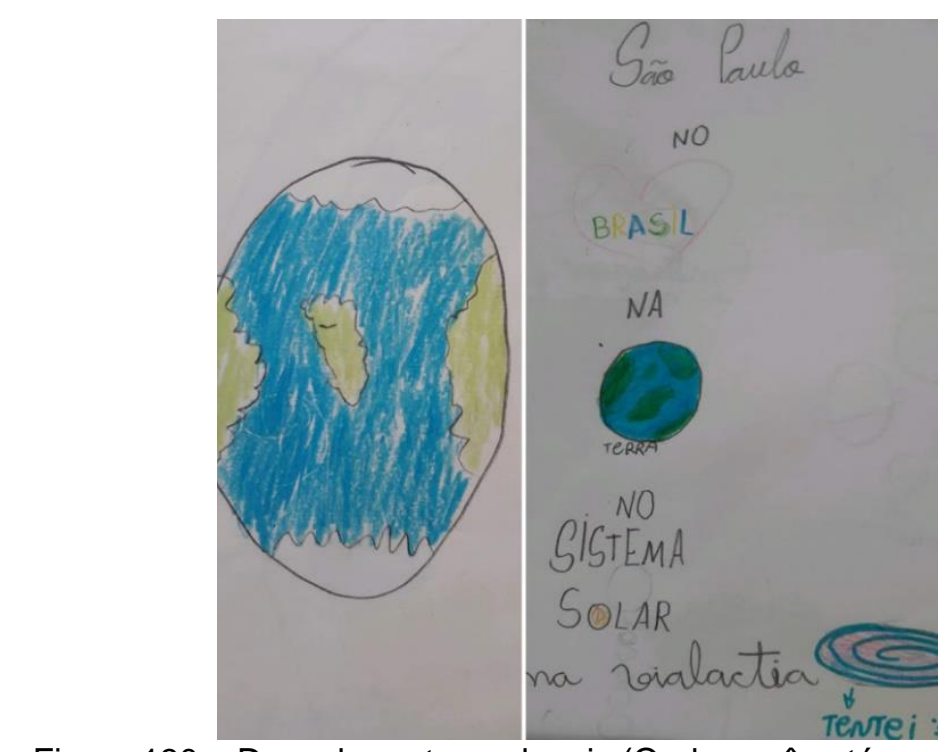

Figura 130 - Desenho antes e depois (Onde você está no planeta?) 
O desenho da figura 131 revela que inicialmente o estudante não conseguiu desenhar nem o planeta Terra, para mostrar a nossa localização. Entretanto termina a SD desenhado o "mapa" de seu país. Outros colegas de turma também optaram por não desenhar o planeta e sim apenas o país, entretanto esta figura nos demonstra a aquisição de novos conhecimentos e como este aluno avançou ao longo de seus estudos.

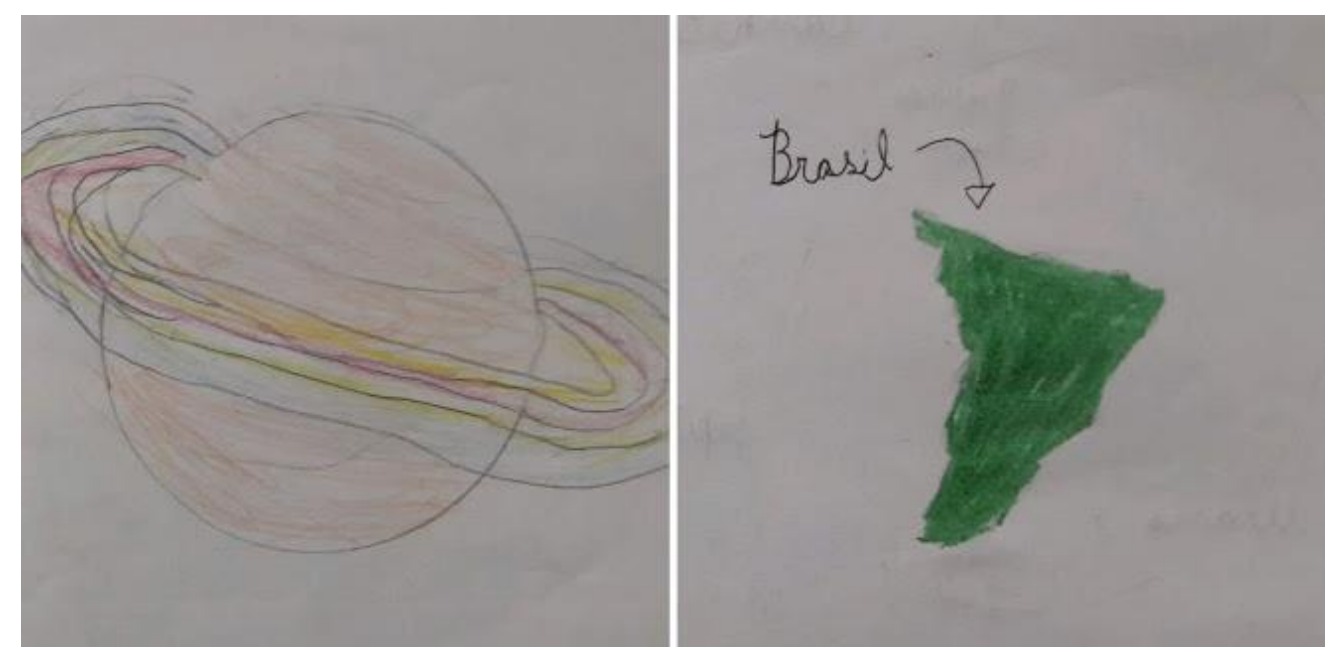

Figura 131 - Desenho antes e depois (Onde você está no planeta?)

Na figura 132 revela-se no desenho inicial um planeta que não se assemelha tanto a Terra vista do espaço. No desenho final o estudante já representa o planeta como se fosse uma fotografia tirada de satélite, e o destaque fica para a América do Sul, onde está localizado o Brasil.

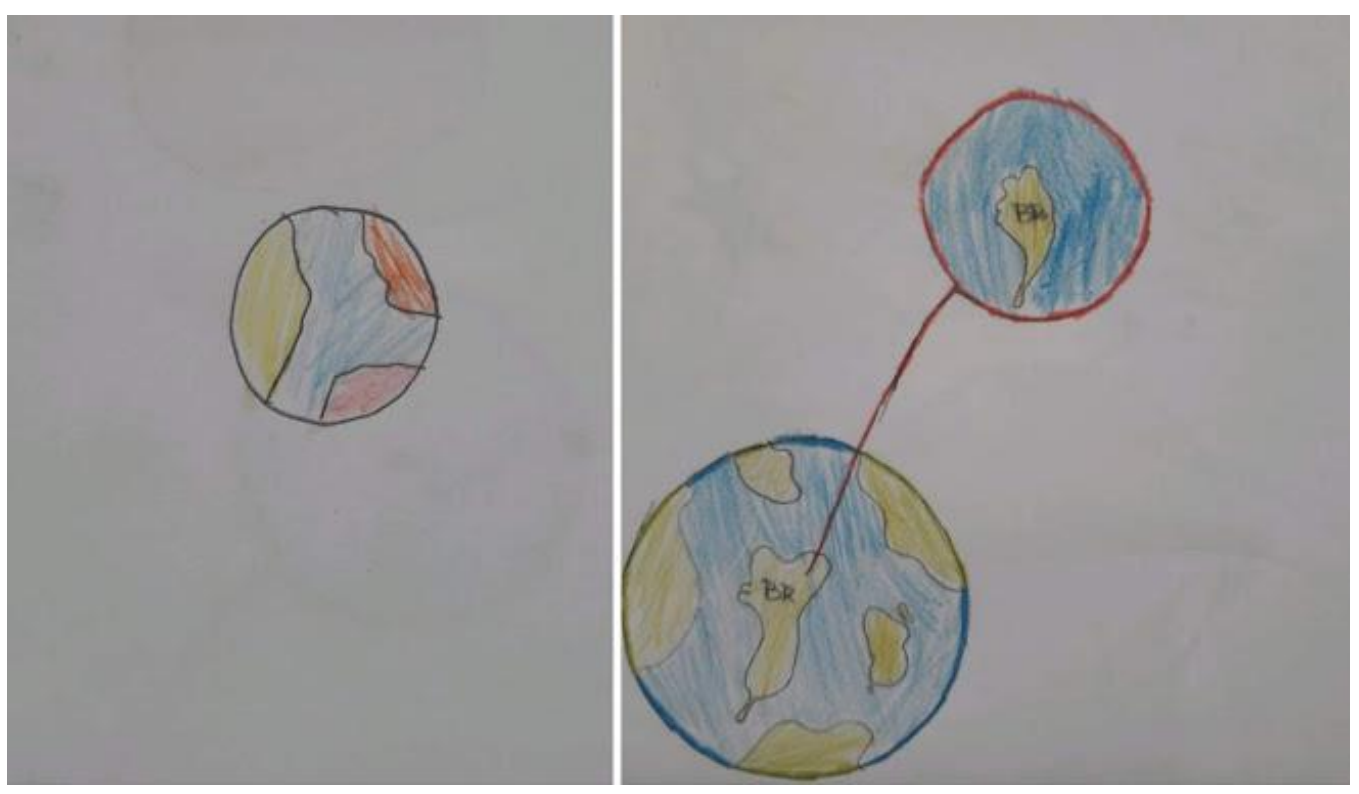

Figura 132 - Desenho antes e depois (Onde você está no planeta?) 
A seguir observaremos os desenhos de outros corpos celestes que os estudantes conhecem.

$\mathrm{Na}$ figura 133, inicialmente o estudante representa diversos planetas, ao final da SD ele já consegue nomear alguns planetas, mostrando que seu conhecimento ampliou desde então. Observam-se inclusive características marcantes dos planetas, como a Mancha Vermelha de Júpiter, a bandeira dos Estados Unidos na Lua e Plutão em um tamanho menor que qualquer astro apresentado.

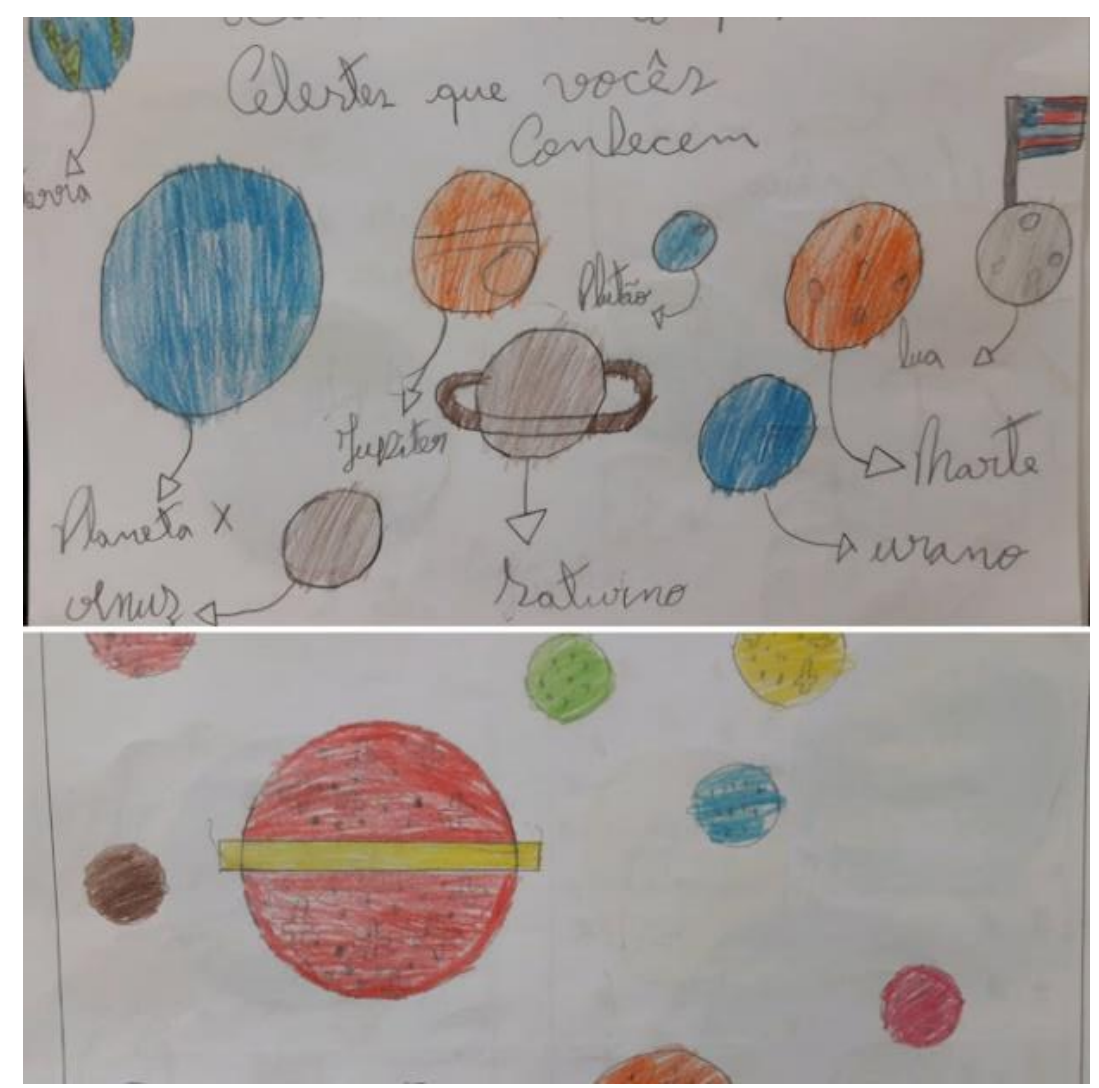

Figura 133 - Desenho antes e depois (Outros corpos celestes que conhece)

No desenho da figura 134, observamos que inicialmente o aluno desenha apenas a Lua, com a bandeira dos Estados Unidos; já em seu desenho final o estudante revela muitas informações que aprendeu, mesmo nem todas sendo nosso foco de estudo. Veja a representação de nebulosas e atribuindo a este local o nascimento de outras estrelas, desenho de uma estrela maior que o Sol, a representação do Big Bang, e uma menção ao planeta Urano com sua rotação retrógrada. 


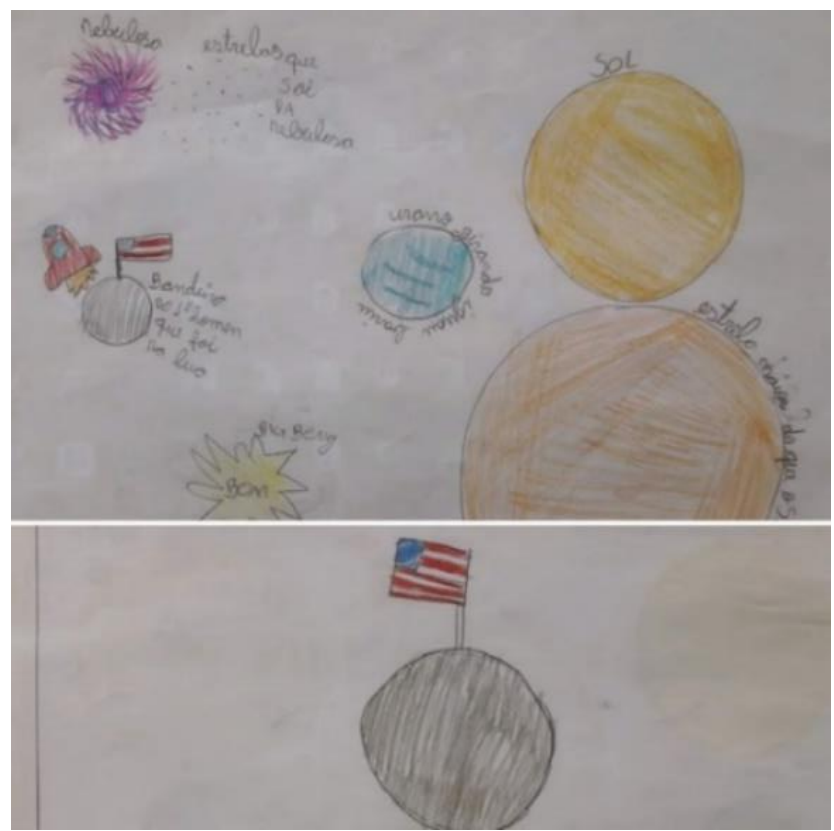

Figura 134 - Desenho antes e depois (Outros corpos celestes que conhece)

$\mathrm{Na}$ figura 135, observa-se que no desenho inicial o aluno representou alguns planetas, estrela, mas não é possível identificar quais astros estava se referindo. No desenho final, o aluno revela além dos planetas do Sistema Solar, com cores semelhantes, tamanhos diversos, também outros elementos como galáxias, estrelas e asteroides.

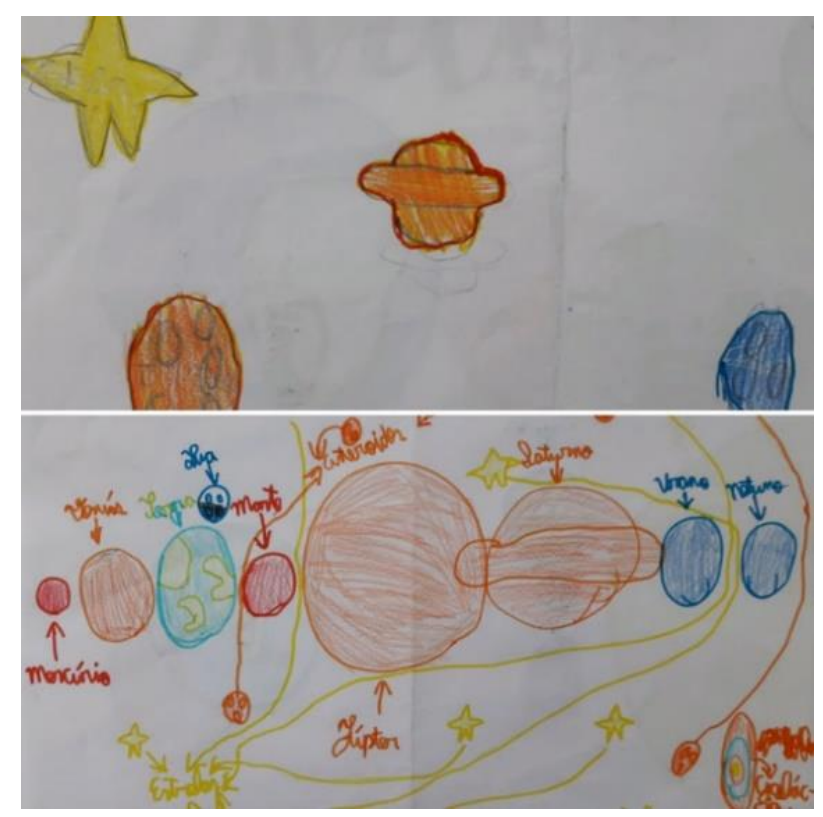

Figura 135 - Desenho antes e depois (Outros corpos celestes que conhece) 
Na figura $X$ observa-se no desenho inicial o aluno já revelou o conhecimento da galáxia Via Láctea, de meteoros, etc. No desenho final o aluno procura mostrar o conhecimento adquirido sobre características dos planetas do Sistema Solar, entretanto organiza os planetas alinhados, fazendo inclusive a menção ao cinturão de asteroides.

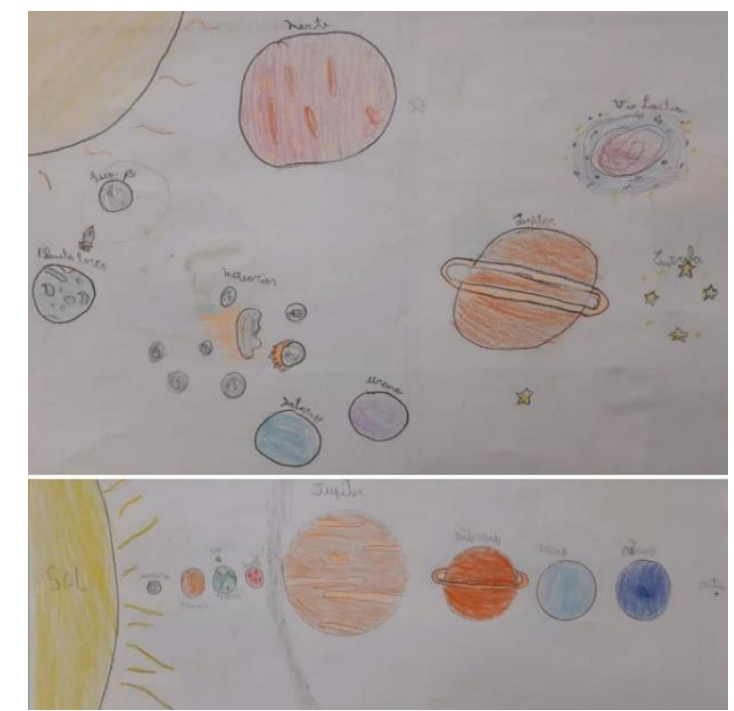

Figura 136 - Desenho antes e depois (Outros corpos celestes que conhece)

$\mathrm{Na}$ figura 136 o estudante inicialmente conseguiu desenhar Saturno e Marte, sem preocupar-se com cores, tamanhos etc. Em seu desenho final, o estudante reúne mais elementos em seu desenho. Ele não chega a desenhar todos os planetas, mas já demonstra conhecer características dos planetas e colocar o Sol como maior que todos os demais.

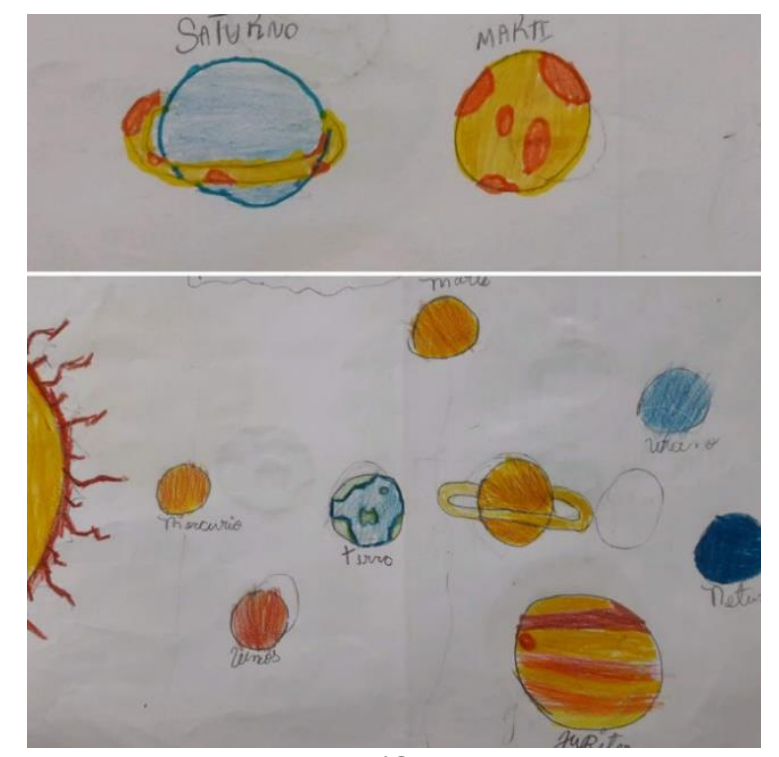

Figura 137 - Desenho antes e depois (Outros corpos celestes que conhece) 
Na figura 137 também se observa que o estudante desenhou o Sol, Terra, Marte, Júpiter e Saturno. Em seu desenho final apresenta-se mais elementos. O aluno nomeia Saturno e um planeta chamado "Senhor dos anéis".

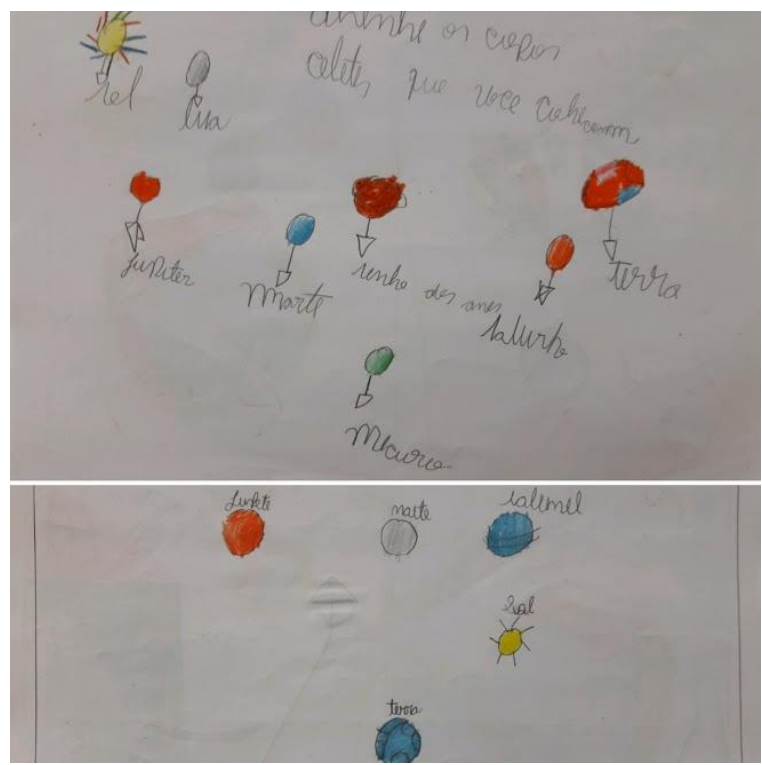

Figura 138 - Desenho antes e depois (Outros corpos celestes que conhece)

$\mathrm{Na}$ figura 139 podemos notar no desenho inicial apenas dois planetas, e no desenho final a representação do Sol, bem maior que os outros astros e todos os planetas do Sistema Solar representados.

Figura 139 - Desenho antes e depois (Outros corpos celestes que conhece)

Podemos concluir que a aprendizagem durante a SD ocorreu de forma diferenciada com cada estudante, respeitando suas possibilidades e amadurecimento. 
Por meio da observação e análise de cada desenho foi possível identificar avanços em vários aspectos, desde a nomenclatura atribuída aos planetas e outros astros que apareceram nos desenhos, como a preocupação com as cores, com os formatos, localização, etc. Em alguns desenhos observamos que foi significativo refletir sobre a comparação de tamanho entre Sol-Terra-Lua, e para outros o mais interessante foi inserir mais elementos que compõem o Universo.

Os questionários também apresentaram resultados de avanço em todos os itens, entretanto revelaram desafios a serem superados, o que nos faz refletir numa Reelaboração da SD, adequando algumas atividades e acrescentando outras, para de fato atingirmos todos os objetivos. 


\section{Capítulo 6 - Reelaboração da SD e conclusão}

A elaboração deste trabalho visava atingir diversos objetivos, e para alcançálos foi construída uma Sequência Didática. Ao final de sua aplicação pode-se afirmar que foi alcançado muito do que era esperado, já que se considerava relevante proporcionar aos estudantes a possibilidade de ampliar seu repertório de conhecimentos básicos em Astronomia, como: debater a origem do Universo comparando mitos e lendas com a formulação de teorias científicas; conhecer elementos que compõe o Sistema Solar, aprofundando informações sobre o Sol, a Lua e a Terra, expandindo para características dos demais planetas do Sistema Solar, além de refletir sobre a importância do cuidado com nosso planeta, pois ele é o único que pode nos abrigar em segurança nesse Universo gigantesco.

Nossa medida para afirmar isto é baseada nos questionários e desenhos realizados pelos estudantes, antes e após a aplicação da SD, bem como sua participação constante em cada atividade proposta. Os estudantes demonstraram em toda aula entusiasmo, motivação, curiosidade, tornando a realização deste trabalho prazerosa, tanto para a professora aplicadora, como para os estudantes participantes.

Por meio deste trabalho, conseguimos identificar a metodologia de Sequência Didática como uma estratégia interessante, pois as sequências de aulas previamente planejadas conferem à prática mais segurança, melhor gestão de tempo e progressão efetiva de aprendizagem, proporcionando uma aprendizagem mais focada, facilitando a compreensão de conteúdos. O planejamento prévio das atividades também proporciona ao educador uma preparação prévia e mais possibilidades em diversificar as estratégias, permitindo aos estudantes mais protagonismo na aprendizagem, mais participação e uma verdadeira construção de conhecimento, o que significa uma aprendizagem mais significativa e eficiente.

Verificamos por meio da fala dos estudantes, da troca de impressões com coordenação pedagógica e família, que o interesse dos estudantes foi fundamental para que este projeto desse certo. Além disso, os resultados nos revelam que os estudantes se sentem mais empoderados em pesquisar, elaborar perguntas e hipóteses, e procurar caminhos para responder as suas indagações, isto é, o princípio básico do fazer científico, demonstrando aos alunos que para ser cientista não é necessário ser um gênio, e sim ser dedicado, interessado, e buscar conhecimento. 
Em outras palavras, esse trabalho procurou "ensinar" aos nossos estudantes que qualquer um deles pode seguir uma carreira na ciência, bastando ter foco, empenho e seguir seus objetivos. E sim, mostrar a eles que a Ciência é fascinante, e a Astronomia é apenas uma de tantas áreas nas quais eles podem se inspirar.

No entanto, apesar dos resultados nos apontarem uma aprendizagem efetiva, se faz necessária uma avaliação de todo o processo, visando realizar ajustes que sejam fundamentais, para que de fato a Sequência Didática seja validada. Chamamos este processo de reelaboração da SD, que segundo Giordan e Guimarães (2013), é quando o professor retoma a elaboração, mas munido de informações e experiências importantes no sentido de aprimorar a SD e a ação docente. Em outras palavras, é o momento de avaliar desde a elaboração e aplicação com um foco investigativo, comparando o alcance dos objetivos aos resultados alcançados. Alguns dos pontos avaliados como importantes para serem reelaborados encontram-se a seguir.

$\mathrm{Na}$ segunda aula da SD, o tema estudado foi a origem do Universo, reunindo lendas e mitos trazidos pelos estudantes, aprofundado com o estudo de uma lenda indígena. A atividade poderia ser potencializada, se ao invés dos estudantes pesquisarem uma lenda para trazer à escola, pudessem obter um momento na própria escola, se possível na aula de informática educativa ou de biblioteca, ao qual tivessem contato com livros ou sites próprios que direcionassem melhor a pesquisa dos estudantes. Assim, a roda de conversa seria enriquecida e apresentada com mais diversidade, que era o esperado para a aula inicial.

Outro ponto importante a ser revisado nesta aula é a formulação do conceito de Universo. Apesar dos estudantes terem pesquisado o significado de Universo e elaborar o conceito em conjunto, isso não foi o suficiente para a compreensão da turma. Para tornar esse aprendizado mais concreto aos estudantes, sugere-se criar um painel interativo ao qual os estudantes são convidados a adicionar elementos que constituem o Universo, desta forma, os alunos receberiam vários desenhos com legenda de elementos constituintes do Universo como estrelas, galáxias, nebulosas, planetas, cometas, satélites, entre outros astros para colarem no painel, e após isto deve-se retomar com os estudantes o conceito de Universo.

Durante a terceira aula os alunos tiveram o contato com a leitura do mito de Andrômeda, além da oportunidade de visualizar a constelação no software Stellarium e na carta celeste. O assunto foi ampliado para o estudo da Via Láctea e nossa 
localização na Galáxia. A aula obteve uma ótima participação da turma, e sendo assim, não se viu necessidade de modificar nenhum item desta aula.

O tema principal da quarta aula foi o Sol. Esta foi uma aula de várias descobertas, um estudante relatou inclusive que não sabia que o Sol é uma estrela. A aula contou com uma pesquisa realizada pela turma, a leitura de texto, exibição e imagens em 3D e um jogo para sistematizar e aprofundar os assuntos estudados. Sendo assim, o formato da aula pode permanecer assim.

O foco da quinta aula foi a Terra. Os estudantes tiveram o contato com a leitura de texto, música, vídeos e atividades práticas. Entretanto, a aula ficou extensa, e acreditamos que as duas atividades práticas sobre os movimentos de rotação e translação poderiam ser realizadas numa aula seguinte, inclusive para os alunos obterem mais tempo para refletir e experimentar. Outro aspecto importante seria incluir na atividade prática a apresentação do fenômeno aos demais colegas, em que cada grupo explicaria como acontecem os dias e as noites; essa troca poderia oportunizar que grupos que ainda apresentem concepções alternativas tenham a possibilidade de rever seu pensamento por meio da interferência da professora ou de outros grupos.

A sexta e sétima aulas tiveram como assunto principal a Lua. Os alunos participaram de diversas atividades, envolvendo a análise de filme de ficção científica e documentários, leitura de textos e músicas, além de uma atividade prática sobre as fases da Lua. Pode-se manter este formato, também.

A oitava aula abordou o tema Sistema Solar. Os alunos participaram da aula e se mostraram muito interessados no vídeo que foi produzido para esta SD. Devido ao entusiasmo, os alunos elaboraram perguntas interessantes sobre os planetas além de ler um texto coletivamente. O formato proporcionou que as próximas aulas fossem de intensa pesquisa pelos estudantes. Funcionou muito bem, e sendo assim avalia-se como adequado manter sua organização original.

A nona e décima aula foram destinadas aos estudantes montarem seus cartazes para a apresentação de suas descobertas, e uma das tarefas era responder as perguntas elaboradas sobre os planetas na aula anterior. Esse formato de responder as perguntas funcionou parcialmente, nem todas as respostas foram encontradas facilmente, e ainda assim, nem todos os alunos apresentam a oportunidade de pesquisar em enciclopédias ou possuem acesso livre à internet em 
casa. Nossa sugestão é manter o formato, mas ampliar o espaço de mais uma aula para proporcionar aos estudantes uma visita à biblioteca ou ao laboratório de informática para auxiliá-los melhor na pesquisa.

A décima primeira aula foi uma atividade prática sobre o tamanho dos planetas; ela foi muito significativa para os estudantes. Sendo assim, pode permanecer do mesmo modo para aplicações futuras.

Podemos manter o formato também da décima segunda aula, que trata das distâncias dos planetas; a visualização proporcional das distâncias surpreendeu os estudantes.

A décima terceira aula foi o momento destinado ao jogo "Uma aventura pelo Sistema Solar". Os alunos participaram ativamente do jogo, gostaram da proposta e não foi apresentado nenhum problema durante o jogo, então podemos mantê-lo também.

A décima quarta aula apesar de ser um momento avaliativo e de conclusão foi fundamental para os estudantes refletirem sobre sua aprendizagem, e rever seus desenhos. A oportunidade de "redesenhar" permitiu aos estudantes avaliarem o quanto se desenvolveram.

As modificações propostas serão adicionadas no Material de Apoio do Professor, que é o produto final desta pesquisa e que será disponibilizado na íntegra no Apêndice e no endereço http://www.iag.usp.br/ eder/CarolinaSilveiraLeite/. A tabela 20 mostra como fica a reelaboração da SD de modo sintetizado:

\begin{tabular}{|c|c|c|c|}
\hline Aulas: & Descrição da atividade & Duração & Tarefa para casa \\
\hline 1 & $\begin{array}{l}\text { Levantamento de conhecimentos } \\
\text { prévios }\end{array}$ & 2 aulas & $\begin{array}{l}\text { Pesquisar uma lenda ou mito que } \\
\text { explica a origem do mundo/ } \\
\text { Atividade compartilhada com } \\
\text { laboratório de informática ou } \\
\text { biblioteca }\end{array}$ \\
\hline 2 & O que é o Universo? & 2 aulas & Ler do Mito de Andrômeda \\
\hline 3 & $\begin{array}{l}\text { Nossa Galáxia: a Via Láctea. Onde está } \\
\text { nosso Sistema Solar? }\end{array}$ & 2 aulas & $\begin{array}{l}\text { Procurar informações sobre a estrela } \\
\text { mais próxima de nós: o Sol }\end{array}$ \\
\hline 4 & A estrela mais próxima de nós: o Sol & 2 aulas & $\begin{array}{l}\text { Pesquisar o que são auroras boreais } \\
\text { e austrais. }\end{array}$ \\
\hline 5 & A Terra & 2 aulas & $\begin{array}{l}\text { Levantar conhecimentos prévios } \\
\text { sobre a Lua, por meio da análise da } \\
\text { letra de uma música. }\end{array}$ \\
\hline 6 & Os movimentos de rotação e translação & 2 aulas & \\
\hline 7 & A Lua ( $1^{\text {a }}$ etapa) & 2 aulas & $\begin{array}{l}\text { Pesquisar informações sobre a Lua } \\
\text { que não descobrimos na aula de } \\
\text { hoje }\end{array}$ \\
\hline 8 & A Lua ( $2^{\mathrm{a}}$ etapa) & 2 aulas & \\
\hline 9 & O Sistema Solar & 2 aulas & $\begin{array}{l}\text { Pesquisar informações sobre um } \\
\text { planeta do Sistema Solar }\end{array}$ \\
\hline
\end{tabular}




\begin{tabular}{|c|c|c|c|}
\hline 10 & $\begin{array}{l}\text { Os planetas - trabalho em grupo II } \\
\text { Pesquisa }\end{array}$ & 2 aulas & \\
\hline 11 & $\begin{array}{l}\text { Os planetas - trabalho em grupo II } \\
\text { Cartaz }\end{array}$ & 2 aulas & $\begin{array}{l}\text { Ensaiar para a apresentação da } \\
\text { pesquisa. }\end{array}$ \\
\hline 12 & $\begin{array}{l}\text { Os planetas - trabalho em grupo III } \\
\text { Apresentação }\end{array}$ & 2 aulas & $\begin{array}{l}\text { Trazer uma imagem que } \\
\text { representam o Sistema Solar. }\end{array}$ \\
\hline 13 & Qual é o tamanho dos planetas? & 2 aulas & $\begin{array}{l}\text { Desenhar o que você aprendeu na } \\
\text { aula de hoje }\end{array}$ \\
\hline 14 & Qual é a distância dos planetas? & 2 aulas & $\begin{array}{l}\text { Escrever como você explicaria os } \\
\text { tamanhos e distâncias dos planetas } \\
\text { do Sistema Solar. }\end{array}$ \\
\hline 15 & Um jogo sobre o Sistema Solar & 2 aulas & $\begin{array}{l}\text { Escrever o que você aprendeu com o } \\
\text { jogo }\end{array}$ \\
\hline 16 & Avaliação: O que eu aprendi? & 2 aulas & Não há \\
\hline
\end{tabular}

Tabela 20 - Reelaboração das aulas da SD

Diante do exposto, pode se chegar à conclusão que os objetivos iniciais da SD foram alcançados e que esta metodologia foi fundamental para o aprendizado dos estudantes e também do professor aplicador, pois, afinal, ambos aprenderam neste processo, os alunos por descobrirem mais sobre os assuntos abordados e o professor por oportunizar a elaboração deste material, sua aplicação e avaliar seu resultados, a fim de conseguir rever o que é necessário melhorar para que o ensino e aprendizagem se tornem mais eficazes.

O Material de Apoio ao professor, que é o produto final este trabalho, visa fornecer aos educadores interessados em trabalhar estes assuntos com seus alunos uma sugestão de atividades possíveis para trabalhar estes temas, e ressalta-se que todas estas aulas e atividades podem ser alteradas e adaptadas pelos professores, pois o intuito é este, fortalecer a prática e inová-la. Esse material é insuficiente inclusive para que nossos alunos terminem a primeira etapa do Ensino Fundamental conhecedores de todos os princípios básicos de Astronomia, tratando-se apenas de um recorte que inicia um tempo, que poderá ser ricamente aprofundado nas séries posteriores. 


\section{REFERÊNCIAS}

AULER, Décio; DELIZOICOV, Demétrio. Alfabetização científico-tecnológica para quê? Ensaio - Pesquisa em Educação em Ciências, v. 3, n. 1, jun. 2001.

BRETONES, P. S. Disciplinas introdutórias e Astronomia nos cursos superiores do Brasil. 1999. 187 f. Dissertação (Mestrado em Geociências) - Instituto de Geociências, UNICAMP, Campinas. . Jogos para o ensino de Astronomia. Campinas-SP: Editora

Átomo, 2013.

BARTELMEBS, Roberta Chiesa. MORAES, Roque. Astronomia nos anos iniciais: possibilidades e reflexões. REP - Revista Espaço Pedagógico, v. 19, n. 2, Passo Fundo, p. 341-352, jul./dez. 2012.

BIZZO, N. Graves erros de conceitos em livros didáticos de Ciência. Ciência Hoje, V.21, N.121, p.26-35, 1996.

. Ciências: fácil ou difícil? São Paulo: Ática, 2002.

BRASIL. Parâmetros Curriculares Nacionais, Ciências Naturais, $1^{1 \mathfrak{a}}$ à 4 série do Ensino Fundamental. Ministério da Educação. Secretaria de Educação Fundamental. Brasília: MEC/SEF, 1997.

BRASIL. Base Nacional Curricular Comum. Fundamental. Ministério da Educação. Secretaria de Educação Fundamental. Brasília: MEC/SEF, 2017.

CARVALHO, A. M. P. (org.) Ensino de ciências por investigação: condições para implementação em sala de aula. São Paulo, Cengage Learning, 2016.

CHASSOT, Attico. Alfabetização científica: questões e desafios para a educação. ljuí: Editora UNIJUÍ, 2000.

CHASSOT, Attico. Alfabetização científica: uma possibilidade para a inclusão social. Rev. Bras. Educ. [online]. 2003, n.22, pp.89-100. ISSN 1413-2478. Disponível em: http://www.scielo.br/pdf/rbedu/n22/n22a09.pdf - Último acesso em 02/08/2018.

DAMINELI, Augusto. STEINER, João (Org.). O Fascínio do universo. São Paulo: Odysseus Editora, 2010.

DÍAZ, José A. A.; ALONSO , Ángel V.; MAS, Maria Antonia M. Papel de la educación CTS en uma alfabetización científica y tecnológica para todas las personas. Revista 
Electrónica de Enseñanza de las Ciencias, v. 2, n. 2, 2003. Disponível em: http://reec.uvigo.es/volumenes/volumen2/REEC 22 1.pdf - Último acesso em 15/08/2018.

FREIRE, P. A importância do ato de ler: em três artigos que se completam. São Paulo: Cortez, 1989.

GUIMARÃES, Y.A.F.; GIORDAN, M. Instrumento para construção e validação de sequências didáticas em um curso a distância de formação continuada de professores. In: VIII ENCONTRO NACIONAL DE PESQUISA EM ENSINO DE CIÊNCIAS. Anais... Campinas, 2011.

. Elementos para Validação de Sequências Didáticas. In: IX ENCONTRO NACIONAL DE PESQUISA EM ENSINO DE CIÊNCIAS. Anais... Águas de Lindóia, SP, 2013.

. Estudo dirigido de Iniciação à Sequência Didática. Curso de Especialização em Ensino de Ciências da FEUSP. Programa Redefor. São Paulo, 2012.

. E MASSI, L. Uma análise das abordagens investigativas de trabalhos sobre sequências didáticas: Tendências no ensino de Ciências. VIII Encontro Nacional de Pesquisa em Educação em Ciências, 2012.

LAGO, L., ANDRADE, R., LOCATELLI, R. Astronomia no ensino de ciências da natureza. São Paulo: Editora Livraria da Física, 2017.

LANGHI, Rodolfo. NARDI, Roberto. Dificuldades interpretadas nos discursos de professores dos anos iniciais do ensino fundamental em relação ao ensino da astronomia. Revista Latino-Americana de Educação em Astronomia - RELEA, n. 2, p. 75-92, 2005.

Ideias de senso comum em astronomia. $7^{\circ}$

Encontro Nacional de Astronomia (ENAST), 2004.

. Ensino de astronomia: Erros conceituais mais comuns presentes em livros didáticos de Ciências. Caderno Brasileiro Ensino de Física, v. 24, n. 1: p. 87-111, abr. 2007. 
Educação em astronomia: repensando a formação de professores. São Paulo: Escrituras Editora, 2012.

LONGHINI, M. D. (org.) Ensino de astronomia na escola. Campinas, SP: Editora Átomo, 2014.

LORENZETTI, Leonir; DELIZOICOV, Demétrio. Alfabetização científica no contexto das séries iniciais. Ensaio - Pesquisa em Educação em Ciências, v. 3, n. 1, jun. 2001. MATTHEWS, Michael R. História, filosofia e ensino de ciências: a tendência atual de reaproximação. Caderno Catarinense de Ensino de Física, v. 12, n. 3, p. 164-214, agosto 1993.

OLIVEIRA, Kepler de; SARAIVA, Maria de Fátima. Astronomia \& Astrofísica. São Paulo: Editora Livraria da Física, 2013.

PAVÃO, A. C.; FREITAS, D. Quanta Ciência há no ensino de Ciências. São Carlos: EdUFSCar, 2017.

PICAZZIO, Enos (Org.). O céu que nos envolve. Introdução à astronomia para educadores e iniciantes. São Paulo: Odysseus Editora, 2011. $1^{\underline{a}}$ ed.

RONCA, A. Teorias de ensino: a contribuição de David Ausubel. Temas psicol., Ribeirão Preto, v. 2, n. 3, p. 91-95, dez.1994. Disponível em $<$ http://pepsic.bvsalud.org/scielo.php?script=sci_arttext\&pid=S1413389X1994000300 009\&lng=pt\&nrm=iso $>$. acessos em 02 jan. 2019.

SASSERON, L. H. MACHADO, V. F. Alfabetização científica na prática: inovando a forma de ensinar física. 1 ed. São Paulo: Editora Livraria da Física, 2017.

. DUSCHI, R. A. Ensino de Ciências e as práticas epistêmicas: o papel do professor e o engajamento dos estudantes. Investigações em Ensino de Ciências. V21, pp. 52-67, 2016.

CARVALHO, A. M. P. Alfabetização científica: uma revisão bibliográfica. Investigações em ensino de Ciências. V16, pp. 59-77, 2011.

SOARES, M. Letramento: um tema em três gêneros. 4. ed. Belo Horizonte: Autêntica, 2010.

SOLÉ, I. Estratégias de leitura. 6. ed. Porto Alegre: Artmed, 1998. 
VIEGAS, Suely. Entrevista: Ouvir estrelas. <http://revistaguiafundamental.uol.com.br/ professores-atividades/86/artigo2196201asp> São Paulo: Escala, 2000. Último acesso em 22/05/2016.

VYGOTSKI, L. S. A formação social da mente. São Paulo: Martins Fontes, 1991.

ZABALA, A. A prática educativa: como ensinar. Porto Alegre: Artmed, 1998. 
APÊNDICE "Material de Apoio" - Sequência Didática "Viagem pelo Sistema Solar".

\section{SEQUÊNCIA DIDÁTICA:}
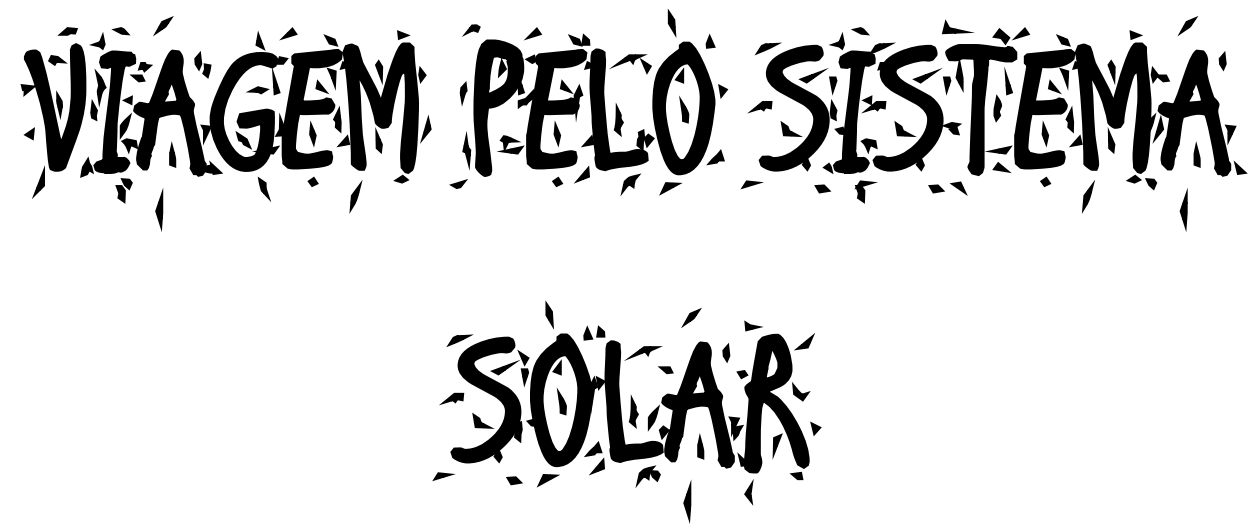

MATERIAL DE APOIO AO PROFESSOR

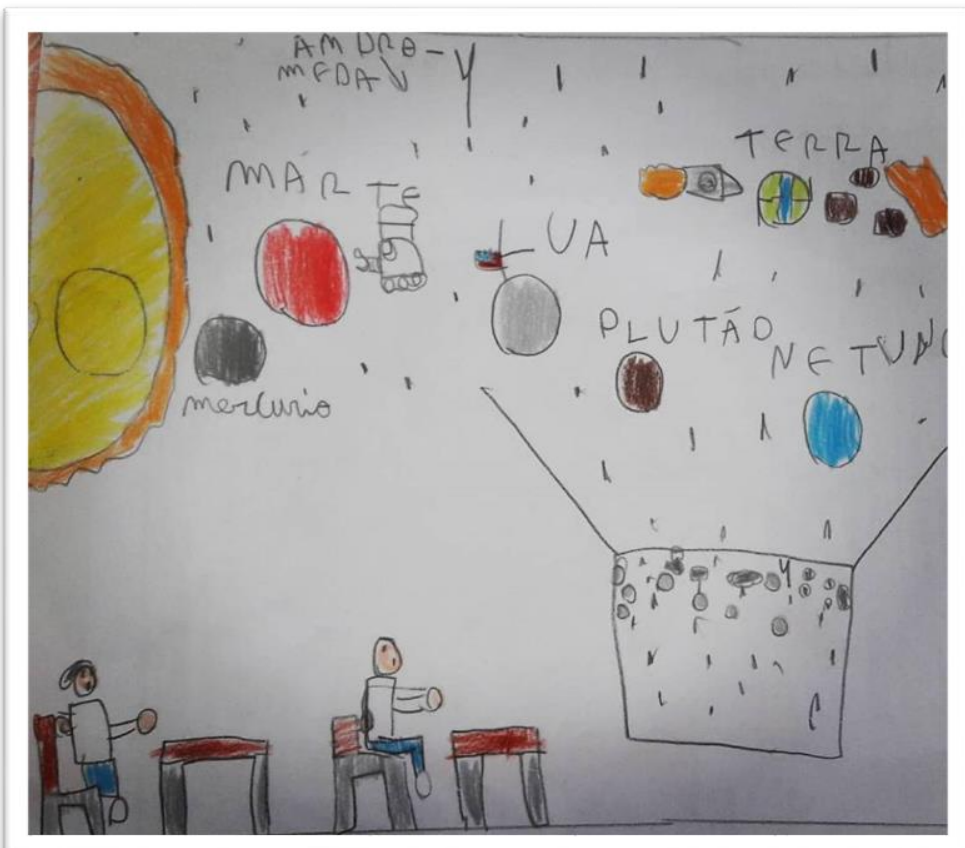

Organização: Carolina Silveira Leite Orientação: Eder Cassola Molina 


\section{Sequência Didática: Viagem pelo Sistema Solar}

Público Alvo: $5^{\circ}$ ano do Ensino Fundamental [ou recomendado a partir do $3^{\circ}$ ano do Ensino Fundamental]

Problematização: A Astronomia é uma ciência que instiga a humanidade desde a Antiguidade. Os filósofos do passado questionavam-se sobre a origem do mundo, a nossa origem, onde de fato estamos, para onde iremos... O que são as estrelas, por que desaparecem com o clarear do dia? Nos dias atuais, apesar de um grande avanço tecnológico, muitas destas perguntas ainda passeiam pelo imaginário das pessoas... Nosso objetivo enquanto educadores não é formar astrônomos, mas despertar em nossos alunos o prazer pela busca pelo conhecimento e por meio desta Sequência Didática aproximá-los mais ainda do fazer científico. A problematização implícita nesta sequência didática é fazer com que nossos alunos criem outras perguntas complexas, e que reflitam sobre a grandeza do espaço, descobrindo que nosso pequeno planeta é precioso, pois abriga a única forma de vida que conhecemos atualmente, e que para preservá-la é necessário conhecê-la, compreendê-la e defendê-la.

\section{Objetivos Gerais:}

- Identificar o Sistema Solar e quais astros fazem parte de sua formação;

- Conhecer lendas e mitos que explicam a origem do mundo, debatendo e refletindo o mítico e o científico;

- Refletir sobre a diferença entre os planetas e suas grandezas;

- Conhecer diversas características de nossa estrela, o Sol, bem como seu tamanho e sua importância para a que exista vida no planeta;

- Descobrir como os planetas se formaram e porque tiveram formações tão distintas;

- Entender por que a Lua muda de aparência;

- Conhecer as características dos planetas do Sistema Solar, comparando-as com a Terra;

- Compreender algumas grandezas de acordo com a proporção de tamanhos;

- Refletir sobre o cuidado e preservação do nosso planeta, já que este é o único lugar possível para abrigar vida. 


\section{Conteúdos:}

\begin{tabular}{|c|c|}
\hline Aula & Conteúdos \\
\hline 1 & - Introdução da SD e atividade diagnóstica. \\
\hline 2 & $\begin{array}{l}\text { - Universo (O que é? Como se formou?); } \\
\text { - } \quad \text { Mitologia para justificar a origem do mundo; } \\
\text { - Teoria do Big Bang; }\end{array}$ \\
\hline 3 & $\begin{array}{l}\text { - } \quad \text { Mito de Andrômeda; } \\
\text { - } \quad \text { A Via Láctea; } \\
\text { - Mito de Hércules e a Via Láctea; }\end{array}$ \\
\hline 4 & $\begin{array}{l}\text { - O Sol (características); } \\
\text { - } \quad \text { Imanchas Solares; } \\
\text { - Eclipse solar; } \\
\text { - } \\
\text { Auroras polares; }\end{array}$ \\
\hline 5 & $\begin{array}{l}\text { - Terra (características físicas); } \\
\text { - } \quad \text { Música "Terra", de Caetano Veloso; } \\
\text { A Terra vista do espaço; }\end{array}$ \\
\hline 6 & - Movimentos de rotação e translação da Terra. \\
\hline 7 & $\begin{array}{l}\text { - A conquista da Lua; } \\
\text { - Filme: Viagem à Lua, de Georges Méliès; }\end{array}$ \\
\hline 8 & $\begin{array}{l}\text { - Lua (características físicas e formação); } \\
\text { - Fases da Lua; }\end{array}$ \\
\hline 9 & $\begin{array}{l}\text { - Sistema Solar (características); } \\
\text { - } \quad \text { Quais astros o compõe (Sol; planetas; satélites, cometas, asteroides, entre outros); }\end{array}$ \\
\hline 10 & - Informações específicas sobre os planetas (pesquisa). \\
\hline 11 & - Organização das informações pesquisadas sobre os planetas (confecção de cartaz). \\
\hline 12 & - Troca de informações pesquisadas sobre os planetas (apresentação). \\
\hline 13 & - Volume dos planetas (proporção) em relação ao Sol. \\
\hline 14 & - Distância dos planetas (proporção) em relação ao Sol. \\
\hline 15 & $\begin{array}{l}\text { - Jogo "Uma aventura pelo Sistema Solar" - Revisão de conteúdos já abordados e novas } \\
\text { curiosidades culturais e científicas sobre o Sistema Solar. }\end{array}$ \\
\hline 16 & $\begin{array}{l}\text { - Retomada dos conteúdos aprendidos, troca entre a turma; } \\
\text { - Conclusão da SD. }\end{array}$ \\
\hline
\end{tabular}

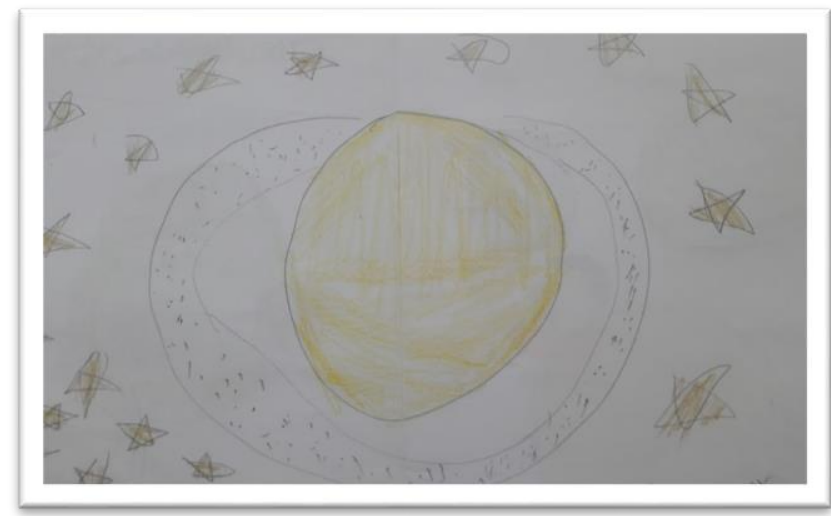




\section{Dinâmicas:}

\begin{tabular}{|c|c|}
\hline Aula & Dinâmicas \\
\hline 1 & $\begin{array}{l}\text { - } \quad \text { Apresentação da SD; } \\
\text { - } \quad \text { Questionário e desenho diagnóstico. }\end{array}$ \\
\hline 2 & $\begin{array}{l}\text { - Levantamento de conhecimentos prévios acerca da palavra Universo; } \\
\text { - } \quad \text { Construção coletiva do conceito de Universo usando como recursos dicionários e enciclopédias); } \\
\text { - Leitura de lendas e mitos sobre a origem do mundo/universo; } \\
\text { - } \quad \text { Roitura compartilhada da lenda "A criação do mundo"; } \\
\text { - Teoria do Big Bang (aula expositiva); } \\
\text { - Vídeo sobre o Big Bang. } \\
\text { - Confecção de painel "No Universo tem..." }\end{array}$ \\
\hline 3 & $\begin{array}{l}\text { - Uso de imagens de galáxias (Andrômeda e Via Láctea); } \\
\text { - } \quad \text { Software: Stellarium; } \\
\text { - } \quad \text { Carta celeste com a constelação de Andrômeda; } \\
\text { - } \quad \text { Projeção de imagens (slides) (aula expositiva); } \\
\text { - } \quad \text { Leitura de mito grego "Hércules e a origem da Via Láctea"; } \\
\text { - } \quad \text { Vídeo com projeção da Via Láctea em 3D; } \\
\text { - } \quad \text { Roda de leitura de enciclopédias e livros de Astronomia. }\end{array}$ \\
\hline 4 & $\begin{array}{l}\text { - Leitura de texto informativo (grifar, localizar informações); } \\
\text { - Vídeo sobre o Sol; } \\
\text { - Imagens em 3D do Sol (usar óculos); } \\
\text { - Jogo de tabuleiro "Uma jornada solar". }\end{array}$ \\
\hline 5 & $\begin{array}{l}\text { - Música “A Terra”, de Caetano Veloso (ouvir e interpretar um trecho); } \\
\text { - Vídeo com imagens da Terra gravados no espaço; } \\
\text { - Leitura compartilhada de texto informativo com procedimentos de estratégia de leitura. }\end{array}$ \\
\hline 6 & - Experimentos para simular os movimentos de rotação e translação da Terra. \\
\hline 7 & $\begin{array}{l}\text { - Música “A Lua”, MPB-4 (ouvir e interpretar); } \\
\text { - } \quad \text { Vídeo: Viagem à Lua, de Georges Méliès; } \\
\text { - } \quad \text { Vídeos documentários sobre a Viagem à Lua em 1969; } \\
\text { - } \quad \text { Comparação dos dois vídeos, o de ficção e o real; } \\
\text { - } \quad \text { Leitura de texto informativo e procedimentos de leitura; } \\
\text { - Elaboração de perguntas. }\end{array}$ \\
\hline 8 & $\begin{array}{l}\text { - } \quad \text { As fases da Lua; } \\
\text { - } \quad \text { Experimento sobre as fases da Lua em uma caixa de papelão; }\end{array}$ \\
\hline 9 & $\begin{array}{l}\text { - Vídeo sobre o Sistema Solar; } \\
\text { - } \quad \text { Elaboração de perguntas sobre os planetas. }\end{array}$ \\
\hline 10 & Pesquisa sobre planetas; \\
\hline 11 & $\begin{array}{l}\text { - Confecção de cartazes; } \\
\text { - } \quad \text { Trabalho em grupo. }\end{array}$ \\
\hline 12 & $\begin{array}{l}\text { - Apresentação de pesquisa realizada utilizando os cartazes produzidos; } \\
\text { - } \quad \text { Autoavaliação. }\end{array}$ \\
\hline 13 & - $\quad$ Atividade prática dirigida sobre o volume dos planetas em tamanho proporcional. \\
\hline 14 & - $\quad$ Atividade expositiva sobre a distância proporcional dos planetas em relação ao Sol. \\
\hline 15 & Jogo “Uma aventura pelo Sistema Solar” \\
\hline 16 & Avaliação (Desenho e questionários). \\
\hline
\end{tabular}




\section{Cronograma de aulas:}

Descrevemos a seguir o passo-a-passo desta Sequência Didática. Primeiro o cronograma de aulas e depois as orientações para cada atividade.

\begin{tabular}{|c|c|c|c|}
\hline Aulas: & Descrição da atividade & Duração & Tarefa para casa \\
\hline 1 & $\begin{array}{l}\text { Levantamento de conhecimentos } \\
\text { prévios }\end{array}$ & 2 aulas & $\begin{array}{l}\text { Pesquisar uma lenda ou mito que } \\
\text { explica a origem do mundo/ } \\
\text { Atividade compartilhada com } \\
\text { laboratório de informática ou } \\
\text { biblioteca }\end{array}$ \\
\hline 2 & O que é o Universo? & 2 aulas & Ler do Mito de Andrômeda \\
\hline 3 & $\begin{array}{l}\text { Nossa Galáxia: a Via Láctea. Onde está } \\
\text { nosso Sistema Solar? }\end{array}$ & 2 aulas & $\begin{array}{l}\text { Procurar informações sobre a estrela } \\
\text { mais próxima de nós: o Sol }\end{array}$ \\
\hline 4 & A estrela mais próxima de nós: o Sol & 2 aulas & $\begin{array}{l}\text { Pesquisar o que são auroras boreais } \\
\text { e austrais. }\end{array}$ \\
\hline 5 & A Terra & 2 aulas & $\begin{array}{l}\text { Levantar conhecimentos prévios } \\
\text { sobre a Lua, por meio da análise da } \\
\text { letra de uma música. }\end{array}$ \\
\hline 6 & Os movimentos de rotação e translação & 2 aulas & *** \\
\hline 7 & A Lua ( $1^{\text {a }}$ etapa) & 2 aulas & $\begin{array}{l}\text { Pesquisar informações sobre a Lua } \\
\text { que não descobrimos na aula de } \\
\text { hoje }\end{array}$ \\
\hline 8 & A Lua ( $2^{\mathrm{a}}$ etapa) & 2 aulas & $* * *$ \\
\hline 9 & O Sistema Solar & 2 aulas & $\begin{array}{l}\text { Pesquisar informações sobre um } \\
\text { planeta do Sistema Solar }\end{array}$ \\
\hline 10 & $\begin{array}{l}\text { Os planetas - trabalho em grupo II } \\
\text { Pesquisa }\end{array}$ & 2 aulas & $\begin{array}{l}\text { Trazer uma imagem que representa } \\
\text { seu planeta de pesquisa. }\end{array}$ \\
\hline 11 & $\begin{array}{l}\text { Os planetas - trabalho em grupo II } \\
\text { Cartaz }\end{array}$ & 2 aulas & $\begin{array}{l}\text { Ensaiar para a apresentação da } \\
\text { pesquisa. }\end{array}$ \\
\hline 12 & $\begin{array}{l}\text { Os planetas - trabalho em grupo III } \\
\text { Apresentação }\end{array}$ & 2 aulas & *** \\
\hline 13 & Qual é o tamanho dos planetas? & 2 aulas & $\begin{array}{l}\text { Desenhar o que você aprendeu na } \\
\text { aula de hoje }\end{array}$ \\
\hline 14 & Qual é a distância dos planetas? & 2 aulas & $\begin{array}{l}\text { Escrever como você explicaria os } \\
\text { tamanhos e distâncias dos planetas } \\
\text { do Sistema Solar. }\end{array}$ \\
\hline 15 & Um jogo sobre o Sistema Solar & 2 aulas & $\begin{array}{l}\text { Escrever o que você aprendeu com o } \\
\text { jogo }\end{array}$ \\
\hline 16 & Avaliação: O que eu aprendi? & 2 aulas & Não há \\
\hline
\end{tabular}

\section{Avaliação:}

A avaliação será de forma contínua, analisando, observando cada participação por meio das atividades realizadas:

- Questionários;

- Desenhos;

- Pesquisas;

- Participação oral;

- Atividades em grupo. 


\section{Descrição das aulas}

\section{Aula 1 - Levantamento de conhecimentos prévios}

Objetivo específico: Descobrir o que a turma já sabe sobre o tema da Sequência Didática e apresentá-la.

Disciplinas envolvidas: Artes, Ciências; Língua Portuguesa.

Duração: 2 aulas.

Material didático: Lápis, folha sulfite A4 (ou modelo impresso do anexo 1), lápis de cor, giz de cera e Questionário (anexo 2).

Referência consultada: SÃO PAULO. Guia de planejamento e Orientações Didáticas para o professor do Ciclo 1 / Secretaria Municipal de Educação. São Paulo: SME/DOT, 2007.

http://www.se-pmmc.com.br/lerescrever/arquivos/professor/3 ano professor.pdf

\section{Descrição da atividade:}

\section{1ํ Momento: Apresentação da proposta (5 a 10 minutos)}

Professor, antes de iniciar a Sequência Didática, é necessário fazer um levantamento dos conhecimentos prévios dos alunos, assim você já consegue descobrir e analisar o perfil da turma para essa nova proposta.

Sugerimos que a princípio você explique que nas próximas aulas eles participarão de uma sequência de atividades sobre Astronomia, e que aprenderão muitas coisas interessantes. Mas que, antes disso, precisamos saber o que eles já conhecem sobre o assunto. Por isso farão duas atividades: uma envolvendo a criação de desenhos e outra respondendo a um questionário.

20 momento: Atividade de desenho (40 a 50 minutos) 
Oriente os alunos a desenharem individualmente em uma folha sulfite:

- A Terra, a Lua e o Sol;

- Onde estamos no planeta;

- Outros corpos celestes que conhecem.

Ajude-os a dividir a folha de modo que possam desenhar todos itens propostos.

Incentive os alunos a escreverem legendas ou comentários na folha.

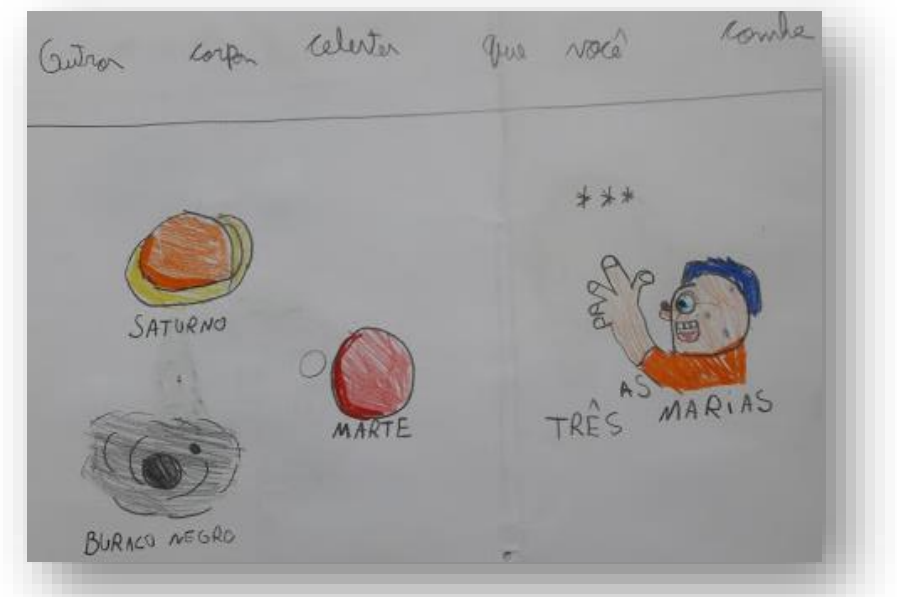

Recolha estas folhas e guarde-as. Ao final desta SD, essas folhas serão devolvidas aos alunos para que eles avaliem o que aprenderam durante o trabalho

$\Delta$ Professor: Em um momento oportuno analise os desenhos, e observe quais conhecimentos sua turma já tem acerca do assunto que irão estudar.

\section{3ำ momento: Questionário diagnóstico (30 minutos)}

Entregue aos alunos a folha com o questionário impresso (anexo 2) ou peça para responderem as perguntas em uma folha separada para lhe entregar. 
Lição de casa: Pesquise* uma lenda ou mito que explica a origem do mundo, escreva em seu caderno para compartilhar com seus colegas de classe.

*Sugestão: Se possível organize uma ida à biblioteca ou a sala de informática para que os estudantes consigam fazer uma pesquisa mais dirigida e assim encontrar textos com qualidade.

\section{Aula 2 - Como surgiu o Universo?}

Objetivo específico: Construir um conceito para o Universo utilizando conhecimentos prévios e pesquisa. Indagar-se de como o Universo surgiu e como os povos antigos procuravam explicar sua origem.

Disciplinas envolvidas: Português; História; Ciências e Geografia.

Duração: 2 aulas

Material didático: Folha impressa (anexo 3 - A origem do mundo*); Folha impressa (anexo 4 - Lição de casa: Mito de Andrômeda); Dicionários e enciclopédias; Acesso ao computador com internet para assistir um vídeo; projetor; caixa de som; Kit painel impresso; cartolinas; cola; tesoura.; fita adesiva transparente.

*Você pode disponibilizar cópias individuais, para serem lidas em duplas, ou apenas uma, que será lida por você.

Referência consultada:

DAMINELI, Augusto. STEINER, João (Org.). O Fascínio do universo. São Paulo: Odysseus Editora, 2010.

OLIVEIRA, Kepler de; SARAIVA, Maria de Fátima. Astronomia \& Astrofísica. São Paulo: Editora Livraria da Física, 2013.

PICAZZIO, Enos (Org.). O céu que nos envolve. Introdução à astronomia para educadores e iniciantes. São Paulo: Odysseus Editora, 2011. 1르 ed. 


\section{Descrição da atividade:}

1을 Momento: Falando sobre o assunto... ( 30 a 40 minutos)

Inicie a aula perguntado aos alunos: O que é o Universo?

Instigue a turma a levantar hipóteses do que é o Universo. Anote no quadro algumas ideias apresentadas por eles.

Depois de algum tempo, procure construir com as ideias sugeridas o conceito de Universo com os alunos. Você, professor, pode utilizar o recurso do dicionário e/ou uma enciclopédia, reunir os conceitos e elaborar um breve parágrafo, conceituando o Universo. Segue um exemplo abaixo:

Dicionário Online de Português: https://www.dicio.com.br/universos/

- Universo: Conjunto de todos os astros com tudo que neles exista.

Dicionário Online Caudas Aulete: http://www.aulete.com.br/universo

- Universo: O espaço e todas as estrelas, planetas e outras formas de matéria nele existente.

Enciclopédia: DRISCOLL, Michael. Céu noturno: uma introdução para crianças: a história das estrelas, dos planetas e constelações e informações sobre como localizá-los no céu. São Paulo: Panda Books, 2009. p.13.

- Universo: Palavra científica que designa a grande e vasta área em que tudo o que conhecemos existe. O Universo às vezes chamado de cosmo. É o conjunto de tudo o que existe (incluindo-se a Terra, os astros, as galáxias e toda a matéria disseminada no espaço), tomado como um todo.

Com estes conceitos reunidos, elabore coletivamente um parágrafo semelhante ao que apresentamos a seguir: 


\section{Universo é...}

O conjunto de todos os astros que existem. É o espaço que ocupam as estrelas, planetas, galáxias e toda a matéria.

Os alunos podem fazer o registro dessa definição no caderno, e então professor, você deve levantar outro questionamento com a turma:

\section{Como surgiu o Universo?}

Permita que os alunos expressem o que pensam sobre o assunto novamente. Após se manifestarem, sugira que contem para os colegas de turma as lendas que encontraram na lição de casa.

A Professor fique atento! Os alunos podem trazer concepções religiosas para debate. Neste momento, todas as opiniões devem ser respeitadas. Cuide para que este espaço de fala seja possível e agradável.

Em seguida, peça que os alunos apresentem suas ideias.

Como acreditam que o Universo surgiu?

Anote algumas ideias apresentadas pelos alunos, e prossiga para a segunda etapa desta aula.

\section{0- Momento: Conhecendo uma lenda ( 20 minutos)}

Prossiga a aula, explicando que muitas civilizações do passado procuraram compreender como o mundo surgiu. Uma delas foi a tribo do povo Araweté, que morava às margens do rio Xingu.

Realize a leitura compartilhada da lenda com a turma, disponível também para impressão no anexo 3. 


\section{A criação do mundo \\ Lenda do povo Araweté, habitante da região do rio Xingu}

Houve um tempo em que o mundo era sem morte e sem trabalho. Existiam na terra os índios e os Mais, uma tribo de imponentes homens-deuses. Não havia as roças e nem o fogo; todos colhiam o mel e as frutas. Não se conheciam a doenças; a velhice e a morte não existiam. A floresta era amiga e os animais, dóceis. Durante as noites, os índios e os Mais fumavam grandes charutos, cantavam e dançavam; não se tinha inventado a mentira e a maldade; todos eram amigos, casavam-se entre si e viviam em harmonia.

O chefe Mai, Ananãmi, havia se casado com uma índia. Moravam felizes em uma aldeia ao lado de árvores cheias de frutos e cipós floridos.

Um dia, sem motivo nenhum, a mulher de Anañami discutiu com ele. Levantou a voz e, aos gritos, o insultou. $\mathrm{O}$ mundo todo parou surpreso. Aquilo jamais havia sido visto.

O grande chefe Mai percebeu então que o paraíso estava morto. Chamou seu sobrinho Hehede, pegou seu chocalho de pajé e começou a cantar e a fumar. Foram rodeados por toda a aldeia, que se espantou quando o solo de pedra, onde estavam os dois, começou a subir sem parar até desaparecer nas alturas. Foi assim que surgiu o céu.

Estava feita a confusão na Terra.

Muitos Mais subiram com Anañami. O céu povoou-se de guerreiros divinos, que levaram o paraíso com eles. As melhores plantas, os melhores animais foram viver nas alturas. Alguns Mais subiram mais alto, criando o céu vermelho que era o céu do céu.

Abandonada e perdendo o seu suporte de pedras, a terra começou a se dissolver em água; jacarés e piranhas esfomeados saíram dos rios e devoraram os índios. Uma tribo Mai, que tinha ficado para trás, afundou n'água e entrou terra adentro. Passou a viver em grandes ilhas nos rios subterrâneos.

Os índios foram desaparecendo um a um. Os que não foram devorados acabaram por afogar-se. Só três pessoas escaparam. Dois homens e uma mulher, mais rápidos que os demais, subiram em um pé de bacaba e de lá assistiram ao desastre. Viriam a ser, depois, os pais de todos os índios.

Quando as águas desceram, a terra estava diferente. Aos poucos, povoou-se de animais ferozes; as árvores já não ofereciam tantas frutas; os sobreviventes tiveram que passar a pescar, caçar e plantar para viver. Anañami teve pena deles e mandou um pássaro vermelho para lhes ensinar a fazer fogo, plantar os roçados, construir canoas e tratar a grande quantidade de doenças que surgiram e a enterrar os mortos.

A vida no céu era muito diferente da que se levava na terra. Lá as sementes brotavam sozinhas, as frutas e o mel estavam ao alcance da mão. Anañami levou o segredo da juventude e não havia nada a fazer além de cantar, dançar e beber cauim. Os deuses eram bonitos e altos, o corpo pintado com tinta de jenipapo de um negro brilhante, e usavam maravilhosos cocares de penas de araras. Tudo era feito de pedra que não estraga com o tempo. E, se o tempo não se fazia sentir ao passar, então a vida deles era sempre presente e não existia futuro.

$\mathrm{Na}$ terra existia o tempo, o envelhecer, o esperar o dia de amanhã. $\mathrm{O}$ futuro. $\mathrm{Na}$ terra existia a esperança. Isso foi um presente de Anañami aos homens.

VAL, Vera do. A criação do mundo: e outras lendas da Amazônia. ilustrações de Geraldo Valério. - São Paulo: WMF Martins Fontes, 2008. P. 13 a 15. 
Ao término da leitura, pergunte a turma:

\section{Será que a origem do mundo é como os Araweté contam?}

Permita que os alunos se manifestem e, em seguida, direcione a aula para o 3o momento, explicando a teoria do Big Bang.

\section{3o- Momento: Explicando o que é a teoria do Big Bang (40 minutos)}

Prossiga a aula, explicando aos alunos que o ser humano sempre olhou para o céu se perguntando o que são as estrelas e como tudo isso se formou. As lendas foram criadas para explicar algo que de fato ninguém sabe como aconteceu.

Explique que há uma teoria, aceita atualmente pelos cientistas chamada Big Bang. Pergunte aos alunos se já ouviram falar nela.

Explique o que é o Big Bang, fazendo com a turma a leitura coletiva abaixo:

$$
\text { O Big Bang }
$$

A teoria do Big Bang é a mais aceita na comunidade científica para explicar a origem do Universo. Eles acreditam que há aproximadamente 14 bilhões de anos, tudo o que existe hoje no Universo estava concentrado em um único ponto. Em determinado momento ocorreu a expansão dessa matéria que ficou conhecida como o Big Bang. Ao serem lançados no espaço, essa energia e matéria, foram sofrendo transformações e dando origem a tudo o que conhecemos hoje. Os cientistas afirmam isso porque ao longo dos anos ao observar as estrelas notaram que elas estão se afastando umas das outras.

Adaptado de: PICAZZIO, Enos (Org.). O céu que nos envolve. Introdução à astronomia para educadores e iniciantes. São Paulo: Odysseus Editora, 2011. 1ํㅡ ed

Disponível em: http://www.astro.iag.usp.br/ damineli/aga105/livroprof.pdf

Para complementar esta aula, mostre o vídeo, da TV Escola sobre o tema. https://tvescola.org.br/tve/video/abc-da-astronomia-big-bang 


\section{4을 Momento: Montando um painel para representar o Universo}

Nesta última atividade, organize a sala num grande grupo e distribua as imagens aos alunos. Explique que eles irão montar um painel colocando nele todos os elementos que compõe o Universo.

Professor, observe que aparecerão estrelas, galáxias, seres vivos, planetas, nebulosas, buracos negros, etc... Vá confrontando a turma acerca das imagens que aparecem, a fim de que eles percebam que todas as imagens disponíveis compõem o Universo.

Mantenha o cartaz exposto na sala por uma semana.

Lição de casa: Leitura e interpretação do mito de Andrômeda (anexo 4).

\section{Aula 3 - Nossa Galáxia: a Via Láctea. Onde está o Sistema Solar?}

Objetivo específico: Conhecer qual é a nossa galáxia; descobrir o local em que está o nosso Sistema Solar na Via Láctea.

Disciplinas envolvidas: Língua Portuguesa, Ciências

Duração: 2 aulas

Material didático: Apresentação de slides "Aula 3_Nossa Galáxia_A Via Láctea”; computador; projetor; software Stellarium (baixar gratuitamente em: https://stellarium.org/pt/) caixa de som. Para a $3^{\text {a }}$ etapa será necessário enciclopédias, revistas, livros, imagens, reportagens, e outros documentos que falem de Astronomia para compor uma roda de leitura; pesquisa sobre o Sol impressa (Anexo 5).

\section{Referência consultada:}

OLIVEIRA, Kepler de; SARAIVA, Maria de Fátima. Astronomia \& Astrofísica. São Paulo: Editora Livraria da Física, 2013.

NOGUEIRA, S. CANALLE, J. B. G. Astronomia: ensino fundamental e médio. Brasília: MEC, SEB ; MCT ; AEB, 2009.- (Coleção Explorando o ensino ; v. 11)

Disponível em: www.oba.org.br/ 
Professor, o passo-a-passo do 1ํmomento desta aula está disponível em

http://www.iag.usp.br/ eder/CarolinaSilveiraLeite/

\section{Descrição da atividade:}

\section{1ํ momento: Relembrando o mito de Andrômeda (30 minutos)}

Inicie a aula retomando a lição de casa sobre a leitura e interpretação do mito de Andrômeda. Em seguida, explique aos alunos que o nome Andrômeda foi dado à galáxia mais próxima de nós. Mostre a imagem da galáxia Andrômeda.

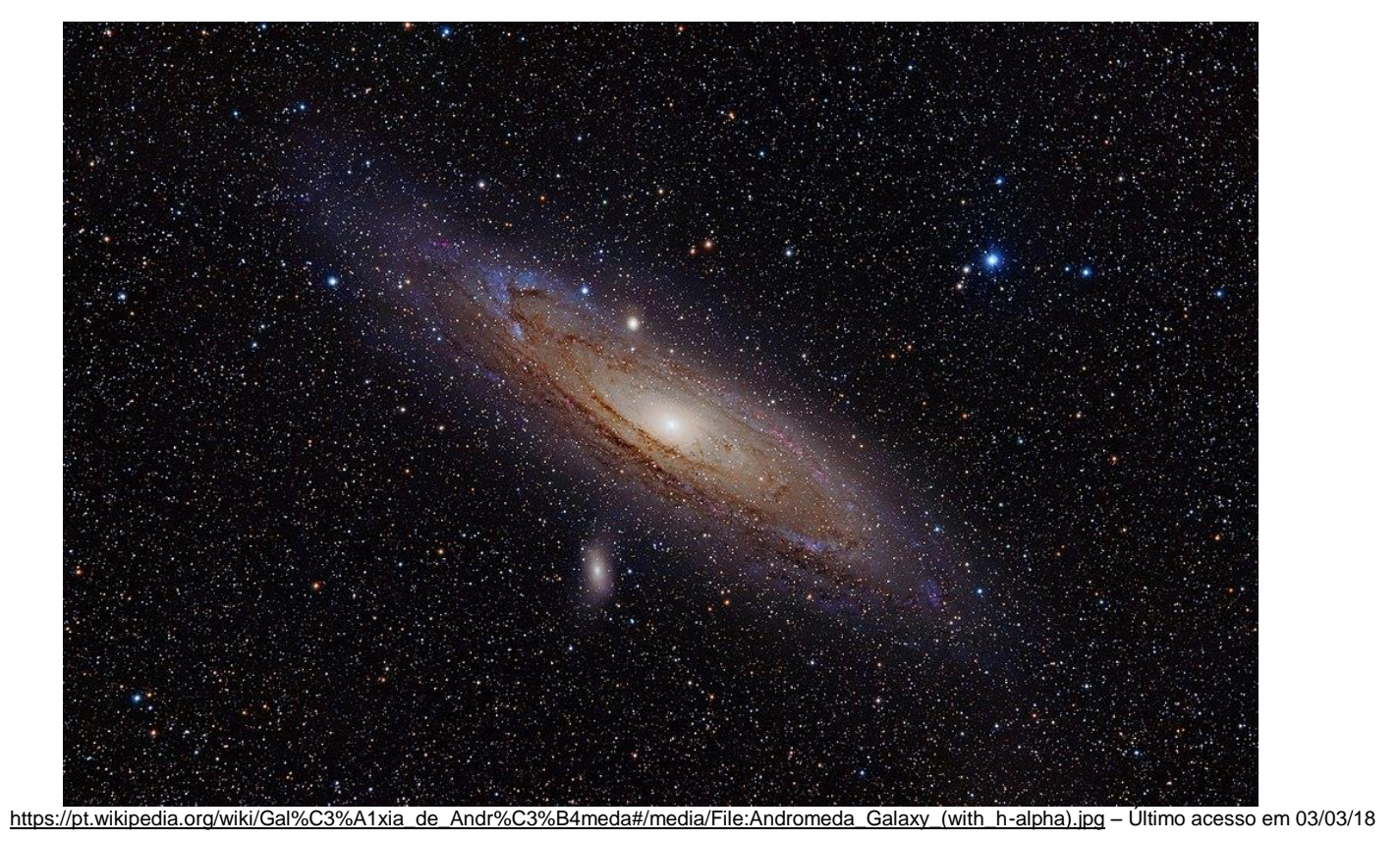

Pergunte aos alunos:

\section{O que é uma galáxia?}

Anote no quadro as ideias dos alunos. Em seguida explique a definição de galáxia, que pode ser: 
Galáxia é um grande aglomerado de estrelas que se mantêm juntas em virtude da gravidade e de outros corpos. Além destas estrelas fazem parte de uma galáxia nebulosas, poeira, gás, planetas, luas e outros corpos celestes.

\section{2ำ momento: A Via Láctea (30 minutos)}

Usando a apresentação com slides, mostre a imagem da Via Láctea.

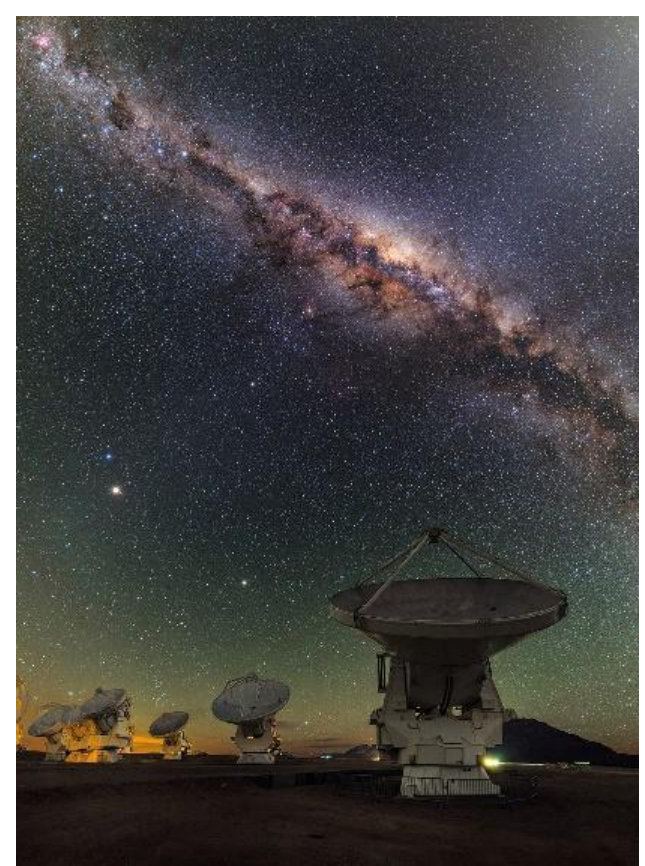

https://commons.wikimedia.org/wiki/File:ALMA and the centre of the Milky Way.jpg

Conte aos alunos que esta imagem é uma foto tirada da Terra, de parte da nossa galáxia: a Via Láctea.

Explique que esse nome foi criado devido a um mito grego... Conte a história:

Conta a lenda, que Hércules era filho de Zeus com uma mortal. Para que Hércules se tornasse imortal deveria tomar o leite da esposa de Zeus, Hera. Entretanto a deusa não gostava do enteado e essa era uma tarefa impossível. Certa noite, enquanto Hera dormia, Zeus pediu a Hermes que levasse o filho bebê para tomar o leite da esposa. Hércules sugou o leite com muita força acordando a deusa. Ela o empurrou 
fazendo com que o leite escorresse deixando um caminho no céu. Este caminho branco formou a Via Láctea. Via Láctea quer dizer "caminho de leite”.

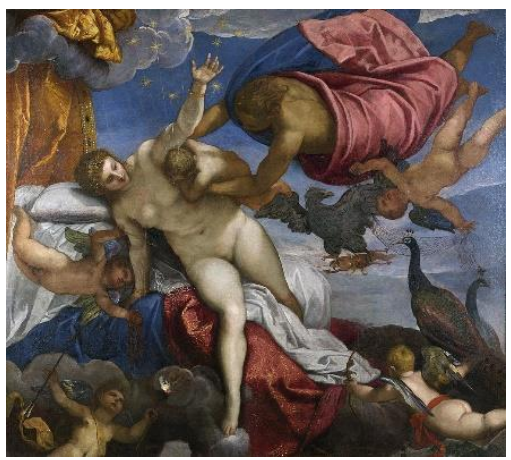

[[Imagem:Jacopo Tintoretto - The Origin of the Milky Way (A origem da Via Láctea)- Google Art Project.jpg|thumb|180px|Legenda]] https://pt.wikipedia.org/wiki/Ficheiro:Jacopo Tintoretto - The Origin of the Milky Way - Google Art Project.jpg

Mostre a imagem da Via Láctea (simulação) e explique que esta imagem não é uma foto real da nossa galáxia (seguir as orientações do ppt). Faça a exibição de um vídeo também, que é uma construção da galáxia em 3D https://www.youtube.com/watch?time continue=4\&v=dtfLbbAZ6FU

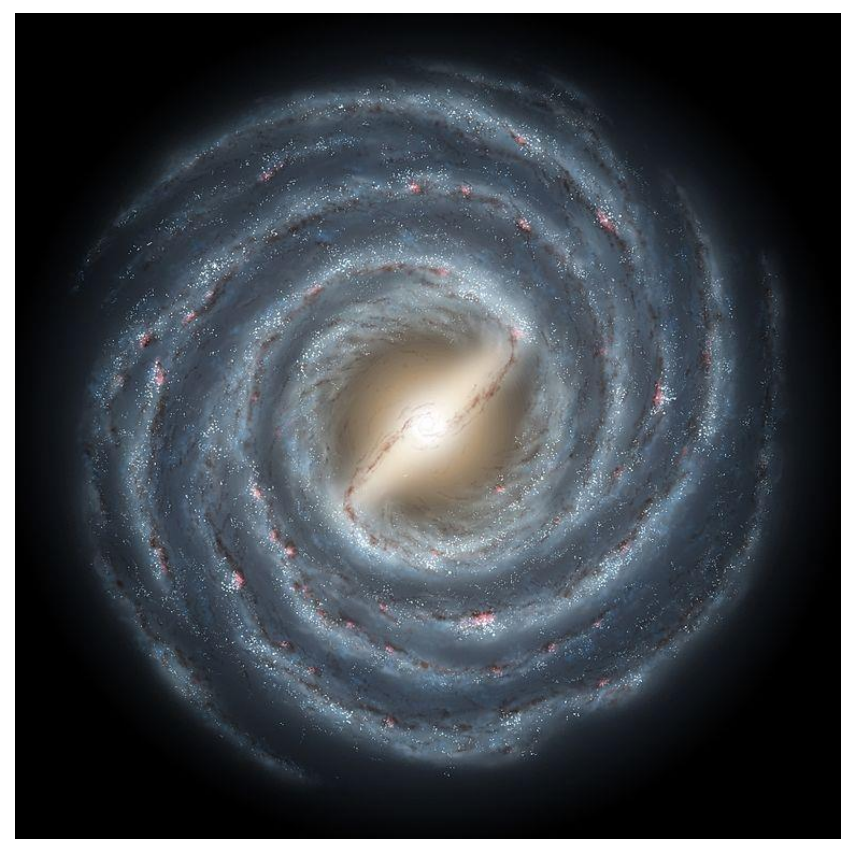

Pergunte:

Onde está o nosso Sol, nessa Galáxia com bilhões de estrelas? 


\begin{abstract}
A apresentação auxiliará bastante os alunos a visualizarem o tema. Aproveite este recurso e finalize sua aula, com um momento descontraído, propondo uma roda de leitura aos alunos.

\section{3ำ momento: Roda de leitura (30 minutos)}

Professor, selecione previamente, enciclopédias, livros, reportagens, revistas, pôsteres, fotografias, dicionários, sobre o tema Astronomia. Reúna os alunos em roda, e permita que eles manuseiem este material, permita que copiem informações de que gostaram. Mostre a eles como consultar o sumário a fim de procurar informações que tenham interesse.
\end{abstract}

Lição de casa: Procure informações sobre a estrela mais próxima de nós: o Sol (Anexo 5).

\title{
Aula 4 - A estrela mais próxima de nós: o Sol
}

Objetivo específico: Descobrir mais informações sobre nossa estrela: o Sol.

Disciplinas envolvidas: Geografia, Ciências, Português e Arte.

Duração: 2 aulas

Material didático: Apresentação em slides “Aula 4_OSol_3D”, óculos 3D, Texto: "Nossa estrela, o Sol (Anexo 6); Pesquisa auroras polares (Anexo 7); Jogo "Uma jornada solar" (todo material do jogo está disponível para impressão em: http://www.iag.usp.br/ eder/CarolinaSilveiraLeite/).

\section{Referência consultada:}

OLIVEIRA, Kepler de; SARAIVA, Maria de Fátima. Astronomia \& Astrofísica. São Paulo: Editora Livraria da Física, 2013.

NOGUEIRA, S. CANALLE, J. B. G. Astronomia: ensino fundamental e médio. Brasília: MEC, SEB ; MCT ; AEB, 2009.- (Coleção Explorando o ensino ; v. 11)

\section{Descrição da atividade:}




\section{0- momento: Lendo um texto sobre o Sol (45 minutos)}

Inicie a aula, perguntando aos alunos quais informações eles encontraram sobre o Sol. Vá lendo pergunta por pergunta, e anote algumas respostas no quadro. Em seguida, entregue aos alunos o texto: Nossa estrela, o Sol.

Professor, realizaremos uma leitura investigativa do texto, para que os alunos comecem a se familiarizar mais com o tipo de texto cientifico que exige uma leitura mais concentrada, pois aparecem vários termos e conceitos desconhecidos. Ensinar os alunos a encontrar informações rapidamente em um texto é fornecer a eles ferramentas necessárias para buscar informações em um texto que pode ser potencialmente interessante. Veja abaixo as instruções:

\section{Antes da leitura:}

Professor explique aos alunos que:

"Nesta aula, nós vamos estudar coletivamente um texto sobre o Sol. Só que será um pouco diferente. Em vez de lermos o texto do começo ao fim, nós vamos buscar formas de encontrar informações mais rapidamente".

Oriente os alunos para que sem ler o texto tentem responder as seguintes perguntas:

- O que são manchas solares?

- O que é um eclipse?

Pergunte aos alunos o que eles precisaram fazer para encontrar as respostas?

Provavelmente eles dirão que deram uma olhada geral no texto, lendo os subtítulos.

Prossiga com mais perguntas: 


\section{- O que é diâmetro?}

- Qual é a temperatura do Sol?

Em seguida proponha a leitura do texto completo. Sugiro que você professor realize a leitura compartilhada, pois como é um texto longo com muitas informações, a estratégia dos alunos lerem cada um trecho pode desfazer o sentido do texto, e menos informações poderão ser compreendidas durante a leitura.

\section{Durante a leitura:}

Durante a leitura interaja com os alunos, perguntando qual é a informação principal do parágrafo; qual frase é importante grifar, etc...

\section{Após a leitura:}

Permita que os alunos façam perguntas sobre o texto e digam o que acharam.

Finalize esta etapa com um vídeo complementar:

https://www.youtube.com/watch?v=ZEiJLhtkfGM Último acesso em 28/10/2018.

$\underline{2^{0} \text { momento: Vendo imagens em 3D sobre o Sol (25 minutos) }}$

Após a leitura do texto, projete a apresentação com imagens do Sol em 3D.

$\Delta$

Professor, você pode comprar os óculos 3D de papel ou confeccionálos previamente com a turma durante uma aula de arte. Há vários modelos disponíveis na internet. Segue um link como uma sugestão para confecção: http://www.manualdomundo.com.br/2012/10/como-fazer-oculos-3d/ Último acesso em 28/10/2018. 


\section{$\underline{3^{\circ} \text { momento: Jogo "O Sol" (20 minutos) }}$}

Para complementar a aula, realize com a turma o Jogo: "Uma aventura solar".

Neste jogo, os alunos poderão aprender mais informações sobre o Sol, e revisar conteúdos que aprenderam na aula de hoje. Em outras aulas, os alunos poderão jogá-lo novamente.

Lição de casa: Pesquisa sobre a Auroras (Anexo 7).

\section{Aula 5 - A Terra}

Objetivo específico: Conhecer como a Terra se formou e algumas de suas características.

Disciplinas envolvidas: Língua Portuguesa, Ciências, Geografia, História.

Duração: 2 aulas

Material didático: Texto impresso para cada aluno "Terra, nosso planeta" (Anexo 8); projetor; música "Terra", de Caetano veloso; Pesquisa sobre a "Lua" (Anexo 9).

\section{Referência consultada:}

OLIVEIRA, Kepler de; SARAIVA, Maria de Fátima. Astronomia \& Astrofísica. São Paulo: Editora Livraria da Física, 2013.

NOGUEIRA, S. CANALLE, J. B. G. Astronomia: ensino fundamental e médio. Brasília: MEC, SEB ; MCT ; AEB, 2009.- (Coleção Explorando o ensino ; v. 11)

Disponível em: www.oba.org.br/

\section{Descrição da atividade:}

\section{1으 momento: Conversando sobre a Terra (30 minutos)}

Inicie a aula ouvindo um fragmento da música "Terra", de Caetano Veloso, disponível em: https://www.youtube.com/watch?v=gMsSrxGwW8U até 1'10'. Ouça mais de uma vez se necessário. 
"Quando eu me encontrava preso

Na cela de uma cadeia

Foi que vi pela primeira vez

As tais fotografias

Em que apareces inteira

Porém lá não estavas nua

E sim coberta de nuvens...

\author{
Terra! Terra! \\ Por mais distante \\ O errante navegante \\ Quem jamais te esqueceria?" \\ https://www.letras.mus.br/caetano-veloso/44780/
}

Após ouvir a música, pergunte aos alunos:

- Quando foi possível observar a Terra pela primeira vez do espaço?

- O que o poeta quis dizer com a frase:

“Porém lá não estavas nua

E sim coberta de nuvens..."

Explique aos alunos que o primeiro homem a sair da Terra e circundar nosso planeta foi Yuri Gagarin, em 12 de abril de 1961. E assim que ele pôde sobrevoar o planeta disse a famosa frase "A Terra é azul".

Mostre aos alunos o vídeo a seguir que apresenta imagens da Terra vista do espaço, até 1'15".

https://www.youtube.com/watch?v=aMwE5J9ImWY - Último acesso em $28 / 10 / 2018$ 
Ao terminar de assistir ao vídeo pergunte aos alunos o que eram as luzes coloridas na superfície do planeta.

Espera-se que as crianças mencionem auroras, entretanto se isso não ocorrer, conte a eles, exibindo o filme novamente para que observem.

Em seguida, comece a conversar com a turma sobre o que encontraram na pesquisa. Verifique o que descobriram de informações.

Terminado esse bate-papo inicial, entregue para os alunos o texto: "Terra, nosso planeta".

2ำ momento: Leitura do texto (30 minutos)

Professor, o objetivo desta leitura é fazer uma análise investigativa do texto. E é claro, ensinar nossos alunos procedimentos de um comportamento leitor. Por isso é fundamental que se siga as etapas propostas abaixo antes, durante e após a leitura.

\section{ANTES DA LEITURA}

- Pergunte aos alunos qual será o assunto do texto;

- Quais elementos eles estão observando para responder isso?

- Pergunte se nesse texto eles vão encontrar informações sobre o planeta Júpiter; e sobre o Sol; e sobre a Lua? Questione os estudantes a medida de suas respostas.

- Oriente aos alunos realizarem uma leitura individual primeiro, e grifar palavras desconhecidas.

\section{DURANTE A LEITURA}

- Leia o texto coletivamente, fazendo uma pausa a cada parágrafo;

- Pergunte qual é a informação importante naquele trecho e incentive-os a grifarem. 


\section{APÓS A LEITURA}

- Pergunte aos alunos quais palavras eles não conhecem e procure no dicionário as respostas;

- Pergunte se eles têm alguma dúvida sobre o texto;

\section{3o momento: Assistindo vídeos sugeridos}

Finalize a aula assistindo com a turma os vídeos sugeridos no próprio texto. Explique que na próxima eles farão uma atividade prática para simular os movimentos de rotação e translação.

\section{Aula 6 - Os movimentos de rotação e translação}

Objetivo específico: Simular os movimentos de rotação e translação para entender algumas de suas funções e saber diferencia-los.

Disciplinas envolvidas: Ciências, Geografia.

Duração: 2 aulas.

Material didático: Lanternas (ou celulares com este recurso); bola de isopor para representar a Terra espetada em palito de churrasco, abajur ou luminária com lâmpada para representar o Sol; globo terrestre; lição de casa sobre a Lua (anexo 9).

\section{Referência consultada:}

OLIVEIRA, Kepler de; SARAIVA, Maria de Fátima. Astronomia \& Astrofísica. São Paulo: Editora Livraria da Física, 2013.

\section{Descrição da atividade:}

\section{1ํ- momento: Atividade prática rotação e translação (30 minutos)}

Após o estudo do texto, pergunte aos alunos como ocorrem os dias e a noites. Permita que eles digam o que sabem, registre algumas contribuições na lousa.

Em seguida inicie a organização do experimento. 


\section{O movimento de rotação: Representando os dias e as noites}

Organize os alunos em grupos e distribua para cada grupo lanternas e uma bola de isopor.

Na frente, o professor demonstra a experiência pedindo o auxílio de um aluno que segurará o Sol representado pela lanterna, enquanto o professor vai girando lentamente a Terra, representada pela bola de isopor. Repita este movimento virado ora para o lado esquerdo da turma, e ora para o lado direito, para que os grupos visualizem o movimento adequadamente. Terminada a demonstração, permita que os grupos façam a atividade. Procure passar em todos os grupos verificando se os alunos estão reproduzindo o experimento de forma adequada.

Após garantir que todos compreenderam o movimento, convide um grupo para representá-lo na frente para todos verem.

Terminada esta primeira etapa, inicie o experimento 2.

\section{O movimento de translação: Representando a volta da Terra ao redor do Sol}

Organize os alunos em uma grande roda com a luminária no centro. Tente deixar o espaço da sala de aula mais escuro.

Pegue o globo terrestre e passe de mão em mão até retornar ao primeiro aluno. Quando isso acontecer a bola terá completado uma translação inteira em torno da luminária que continuará a fazer o papel do Sol.

\section{Questione: 0 que aconteceu com a Terra?}

Espera-se que os alunos respondam que ela "deu" uma volta completa ao redor do Sol.

Questione: 0 que acontece quando a Terra dá uma volta completa ao redor do Sol?

Espera-se que eles concluam que se completa um ano na Terra, ou seja, se passaram 365 dias (aproximadamente). 


\section{Questione: Se a Terra gira ao redor do Sol, por que parece que ele é quem gira em volta da Terra?}

Escute as ideias dos alunos, depois explique que Terra gira e por isso ela dá a impressão de que o "Sol" está passando no céu.

\section{Professor: Podem surgir nesse momento perguntas sobre o ano}

bissexto ou sobre as estações do ano. Nesta atividade não iremos

ampliar esta discussão, mas no campo Referência Comentada há

sugestão de materiais que abordam este tema.

Continue o experimento:

Um dos alunos deverá girar em torno da luminária segurando o globo terrestre enquanto os outros acompanham o movimento. Isso mostrará que há uma diferença grande entre a rotação (girar em torno do próprio eixo) e translação (girar em torno do Sol).

Lição de casa: Levantar os conhecimentos prévios dos alunos sobre a Lua, analisando as estrofes de uma música (Anexo 9).

\section{Aula 7 - A Lua (1ª etapa)}

Objetivos específicos: Descobrir informações sobre a Lua e suas características.

Disciplinas envolvidas: Arte, Português, Ciências.

Duração: 2 aulas

Material didático: Acesso à internet, projetor, caixa de som.

\section{Referência consultada:}

OLIVEIRA, Kepler de; SARAIVA, Maria de Fátima. Astronomia \& Astrofísica. São Paulo: Editora Livraria da Física, 2013.

NOGUEIRA, S. CANALLE, J. B. G. Astronomia: ensino fundamental e médio. Brasília: MEC, SEB ; MCT ; AEB, 2009.- (Coleção Explorando o ensino ; v. 11)

Disponível em: www.oba.org.br/ 


\section{Descrição da atividade:}

10 momento: Refletindo sobre a conquista da Lua (45 minutos)

Inicie a aula ouvindo com os alunos a música "A Lua", do grupo MPB-4. Entregue a letra da música na íntegra para que os alunos possam ouvir. Em seguida, retome com os alunos as questões propostas na lição de casa.

Continue a discussão, assistindo ao primeiro filme de ficção científica "Viagem à Lua", de Georges Méliès, disponível no endereço abaixo:

\section{https://www.youtube.com/watch?v=leXpc2vBG-w (aproximadamente 15')}

$\mathrm{Na}$ introdução do vídeo há uma breve explicação do contexto em que o vídeo foi produzido, mas é interessante chamar a atenção dos alunos sobre a importância desse vídeo, por ser o primeiro de ficção científica. Se os alunos não souberem o que é um filme de ficção científica cite alguns dos filmes conhecidos por eles como Jurassic World, Star Wars, Homem Aranha, etc... e eles compreenderão do que se trata.

Analisando a exibição do vídeo:

- Nos primeiros 2 minutos de exibição questione os alunos sobre o que as pessoas estão fazendo. Ajude-os a concluir que estão fazendo uma reunião. E que há o personagem que está dando explicações, fazendo anotações no quadro.

- Em 2'43" pergunte aos alunos qual é o assunto desta reunião (ir á Lua, já que se desenha a trajetória de um foguete até o satélite). Questione os alunos sobre a reação das pessoas presentes;

- Em 2'58" o que acontece na reunião? Será que todos concordaram com a ideia? Pare a exibição do filme e pergunte aos alunos porque nem todos concordaram com a ideia. 
- E 2'33" o que acontece com os demais participantes? Ao "darem o aperto de mão" o que isto significa?

- Em 4'28" o que ocorre? Espera-se que os alunos digam que inicia-se a construção de um foguete para levá-los à Lua.

- Em 5'48" questione os alunos sobre o que vai acontecer. Espera-se que falem que é o dia do lançamento do foguete. O dia da tão esperada viagem à Lua;

- Pause o vídeo em 7’29 e pergunte aos alunos se esta viagem dará certo e por quê. Em seguida, continue a exibição.

- Aos 8'00" pause novamente o vídeo e permita que os alunos falem o que pensam. Por que a Lua tem olhos e boca? Por que saiu sangue da Lua? Pergunte o que eles acham que ocorrerá agora. Em seguida retome a exibição do filme.

- Em 8'45" o que os personagens visualizam ao fundo? Os alunos dirão que é a Terra.

- Em 11'13" o que acontece? Aparece um habitante da Lua.

- Em 12'15" se descobre que há um reino na Lua.

- Finalize a exibição do vídeo com o retorno dos aventureiros à Terra.

Mostrar este filme, é proporcionar aos alunos uma reflexão sobre o interesse da humanidade em conhecer e conquistar a Lua. Muitos imaginavam que poderia existir outro mundo lá. Afinal, ela é o astro mais próximo de nós e o mais brilhante no céu noturno.

Aproveite esta reflexão e pergunte:

\section{- O que vocês gostariam de saber sobre a Lua?}

Anote de 3 a 5 perguntas, para não estender muito o tempo de aula. Explique que se não conseguirem responder as perguntas, poderão de realizar uma pesquisa mais aprofundada. 
20 momento: Assistindo outros dois filmes (45 minutos)

Em seguida, apresente a turma mais dois vídeos:

- a simulação da viagem à Lua em 1969, com algumas imagens reais do pouso em nosso satélite natural;

Viagem à Lua: Voo simulado pela NASA - 7'44"

https://www.youtube.com/watch?v=Pht19m8HJxM

- um documentário com imagens reais da viagem.

A conquista da Lua dublado - 10'33"

https://www.youtube.com/watch?v=5dfmNroYvZ0

Sugira que os alunos façam comparações entre o filme "Viagem à Lua" e os dois últimos filmes, da viagem em 1969.

\section{Pergunte:}

1) Quais semelhanças podemos encontrar entre os dois filmes?

2) Quais diferenças?

3) No primeiro filme existiam habitantes na Lua. O que se descobriu quando puderam visitá-la?

4) Por que não há vida na Lua?

Escreva no quadro as contribuições e reflexões da turma.

\section{Aula 8 - A Lua ( $2^{\mathrm{a}}$ etapa)}

Objetivo específico: Compreender como a Lua muda de aparência e saber nomear e identificar algumas de suas fases.

Disciplinas envolvidas: Ciências; Geografia.

Duração: 2 aulas.

Material didático: Texto informativo sobre a Lua (anexo 10); 
Experimento das fases da Lua (preparar previamente) disponível em:

http://www.cienciamao.usp.br/tudo/exibir.php?midia=Icn\&cod= simulacaoumaformaderepre

http://www.if.ufrgs.br/mpef/mef008/trabalhos 06/Carmes FL.htm

\section{Referência consultada:}

http://www.cienciamao.usp.br/tudo/exibir.php?midia=Icn\&cod= simulacaoumaformaderepre http://www.if.ufrgs.br/mpef/mef008/trabalhos 06/Carmes FL.htm

\section{Descrição da atividade:}

1ㅇ momento: Aprendendo mais sobre a Lua (45 minutos)

Entregue o texto "A Lua, o único satélite natural da Terra" e escreva na lousa as cinco perguntas feitas pelos alunos no início da aula. Em seguida, pergunte a turma, se eles conseguem identificar sem ler o texto, se é possível encontrar as respostas destas perguntas.

Logo depois, permita que os alunos façam uma leitura prévia do texto em duplas.

Terminado este prazo, pergunte novamente, quais das perguntas feitas por eles já estão respondidas no texto.

Só depois, faça a releitura do texto, agora coletivamente com a turma.

Use os recursos de grifar informações importantes, para que os alunos percebam a importância de utilizar este recurso para estudar.

\section{2o- momento: Como a Lua muda de forma? (45 minutos)}

Assista ao vídeo as Fases da Lua, da série $A B C$ da Astronomia https://www.youtube.com/watch?v=N2wTtaJEtNY

Realize uma atividade prática para explicar as fases da Lua. Para isso é necessário confeccionar antes a caixa com a bola de isopor e a lanterna para os alunos conseguirem observar as fases da Lua.

Explique aos alunos que ao olharem pelo orifício, eles estarão simulando como se estivessem observando a Lua daqui da Terra. 
É muito importante explicar aos alunos que Terra-Sol-Lua não ficam num mesmo plano no espaço; se fosse assim teríamos todo mês um eclipse. Estes astros estão em planos de órbitas diferentes, e ocasionalmente, quando se alinham (parecem se alinhar, mas numa determinada região, vistos aqui da Terra) dá-se o eclipse. Na bibliografia sugerida há mais informações a respeito.

Com o experimento pronto, reúna os alunos e permita que eles observem a caixa, olhando pelas aberturas. Na caixa eles observarão que a Lua estará iluminada de diferentes formas. E poderão visualizar algumas fases marcantes como a Lua Cheia ou a Lua Nova.

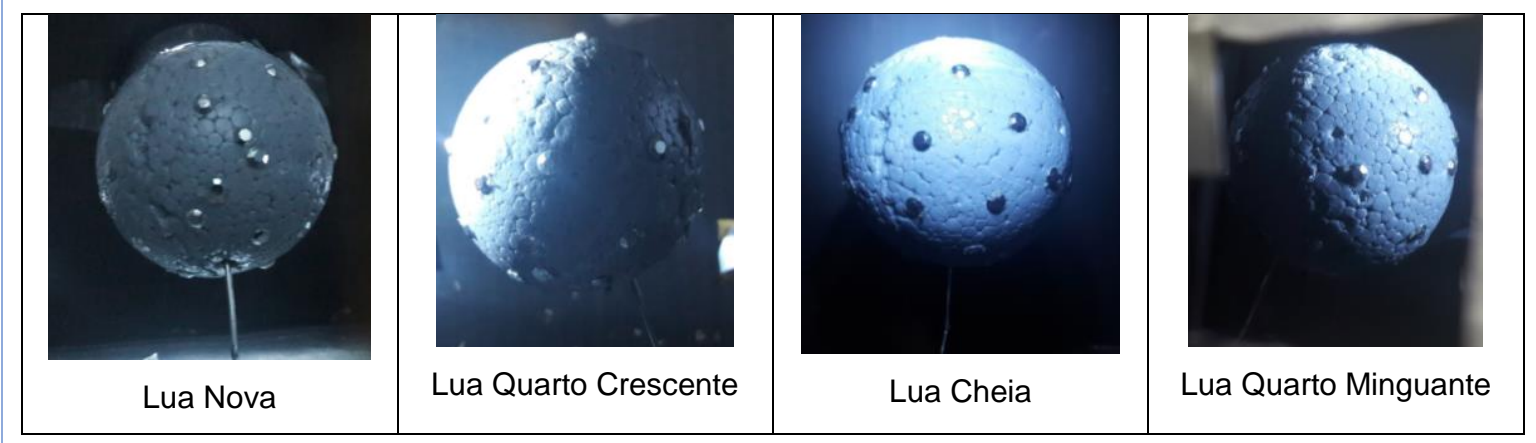

Após todos terem olhado o experimento, proponha oralmente as seguintes perguntas aos alunos.

- Quais foram as fases da Lua que você conseguiu observar no experimento?

- Nas janelinhas intermediárias, como aparecia a iluminação da Lua?

- É correto afirmar que a Lua cada dia apresenta um formato? Como você conseguiria comprovar isso com o experimento de hoje?

Lição de casa: Pesquise informações sobre a Lua que não foram respondidas na aula de hoje. 
Objetivos específicos: Ampliar os conhecimentos dos alunos sobre o Sistema Solar; Descobrir como o Sistema Solar se formou; Identificar os astros que fazem parte deste sistema; elaborar perguntas sobre informações que desejam descobrir sobre os planetas.

Disciplinas envolvidas: Língua Portuguesa, Matemática, Ciências, Geografia.

Duração: 2 aulas

Material didático: Projetor, computador, caixa de som, texto "Nosso Sistema Solar" (anexo 11); vídeo "Sistema Solar"; Apresentação de slides dos planetas, tudo disponível também em: http://www.iag.usp.br/ eder/CarolinaSilveiraLeite/

\section{Referência consultada:}

OLIVEIRA, Kepler de; SARAIVA, Maria de Fátima. Astronomia \& Astrofísica. São Paulo: Editora Livraria da Física, 2013.

NOGUEIRA, S. CANALLE, J. B. G. Astronomia: ensino fundamental e médio. Brasília: MEC, SEB ; MCT ; AEB, 2009.- (Coleção Explorando o ensino ; v. 11)

\section{Descrição da atividade:}

\section{0 momento: Assistindo um vídeo sobre o Sistema Solar (45 minutos)}

Iniciar a aula, assistindo a um vídeo sobre o Sistema Solar (13'24"), produzido para esta aula:

\section{https://www.youtube.com/watch?v=|pHTVaFVUJw\&feature=youtu.be}

Ao fim do vídeo, permita que os alunos falem suas impressões sobre o vídeo. Quais informações eles já sabiam e quais informações puderam descobrir, etc.

Em seguida, proponha uma leitura silenciosa do texto: "Nosso Sistema Solar".

Oriente os alunos a realizarem uma nova leitura e pergunte quais informações eles destacaram e que desejam compartilhar com os colegas. 
20 momento: Elaborando perguntas sobre os planetas (45 minutos)

Apresente as imagens dos planetas e incentive os alunos a elaborarem perguntas sobre o que desejam descobrir sobre estes astros.

Anote no máximo 5 perguntas de cada planeta.

\section{3o- momento: Organizando grupos de pesquisa}

Organize os alunos em nove grupos, oito que encontrarão informações sobre os planetas e mais um que pesquisará informações sobre Plutão, o planeta-anão. No anexo 12 há informações de como organizar a turma para a pesquisa. Combine que eles terão uma aula disponível para pesquisar as informações na escola também.

Lição de casa: Dividir a turma em grupos para pesquisarem sobre os planetas e suas perguntas (Anexo 12 - disponível no link:

https://drive.google.com/drive/u/0/folders/1qf-

NotuudZzqgRIN27Pt5FVFXKaA19XU).

\section{Aula 10 - Os planetas - Trabalho em grupo I - Pesquisa}

Objetivos específicos: Pesquisar informações sobre os planetas.

Disciplinas envolvidas: História, Geografia, Língua Portuguesa, Arte e Ciências.

Duração: 2 aulas

Material didático: Computadores com acesso à internet, livros e enciclopédias de astronomia.

\section{Descrição da atividade:}




\section{1ํ- momento: Organizando as informações}

Oriente os estudantes a se reunirem em grupos e verificarem quais informações conseguiram descobrir sobre os planetas e quais ainda faltam. Entreguem a professora o material já encontrado para ela verificar e corrigir, enquanto eles pesquisarão as informações que ainda não foram descobertas.

\section{0 momento: Pesquisando}

Professor, organize previamente o laboratório de informática com estações, rodiziando o uso dos computadores e livros entre os estudantes. No laboratório instrua em quais sites eles devem pesquisar as informações, para que não fiquem perdidos, tais como:

- Ciência Hoje das Crianças http://chc.org.br/?s=astronomia

- Coleção Explorando o Ensino de Astronomia http://www.oba.org.br/sisglob/sisglob arquivos/downloads/Explorando o en sino astronomia.pdf

3o momento: Organizando a pesquisa para o cartaz

Explique a turma que na próxima aula eles irão montar o cartaz. Releia o anexo 12, para que entendam quais materiais deverão trazer para fazer o trabalho.

Lição de casa: Trazer imagens dos planetas e informações sobre eles.

\section{Aula 11 - Os planetas - Trabalho em grupo II - Cartaz}

Objetivos específicos: Confeccionar cartazes para apresentar informações sobre os planetas.

Disciplinas envolvidas: Ciências, Língua Portuguesa; Arte. 
Duração: 2 aulas

Material didático: Cartolina, tesoura, régua, lápis de cor, cola, canetinha, tintas diversas, imagens dos planetas impressas ou desenhadas, livros e enciclopédias.

\section{Descrição da atividade:}

Nesta aula os alunos em grupos utilizarão as informações encontradas para elaborar um cartaz com as principais informações encontradas. Também poderão utilizar enciclopédias para finalizar a pesquisa.

Auxilie os alunos a se organizarem. Ajudando-os a seguir as orientações da ficha de pesquisa.

Eles devem produzir um cartaz para auxiliar na explicação e ensaiar a apresentação.

Lição de casa: Ensaiar para a apresentação da pesquisa.

\section{Aula 12 - Os planetas - Trabalho em grupo III - Apresentação}

Objetivos específicos: Apresentar as descobertas realizadas com a pesquisa, utilizando o cartaz como estratégia.

Disciplinas envolvidas: Ciências, Língua Portuguesa; Arte.

Duração: 2 aulas

Material didático: Cartazes confeccionados, Autoavaliação (anexo 13).

\section{Descrição da atividade:}

Nesta aula, organize os alunos de modo que a sala fique receptiva para as apresentações.

Os alunos contarão aos colegas o que descobriram durante a pesquisa.

Exponha os cartazes na sala de aula.

Ao terminar as apresentações permita que os alunos se autoavaliem (Anexo 13). 


\section{Aula 13 - Qual é o tamanho dos planetas?}

Objetivos específicos: Visualizar os tamanhos dos planetas em relação ao Sol de forma proporcional.

Disciplinas envolvidas: Artes, Geografia, Ciências, Matemática.

Duração: 2 aulas

Material didático: Massinha de modelar, folha com o molde dos planetas, bola.

Referência consultada:

Atividade dos planetas em volume (p. 83 a 88)

http://www.oba.org.br/sisglob/sisglob arquivos/downloads/Explorando o ensino astrono mia.pdf

https://www.youtube.com/watch?v=obXOcqEWf-c

http://astronomiareal.blogspot.com.br/p/grandezados-planetas-em-relacao-ao-sol.html

\section{Descrição da atividade:}

Adaptamos esta atividade a partir das referências citadas. Substituímos 0 material por massinha de modelar para atrair mais a atenção dos estudantes, e funcionou muito bem.

Reduzimos um pouco mais o diâmetro do Sol para se adequar ao tamanho da bola.

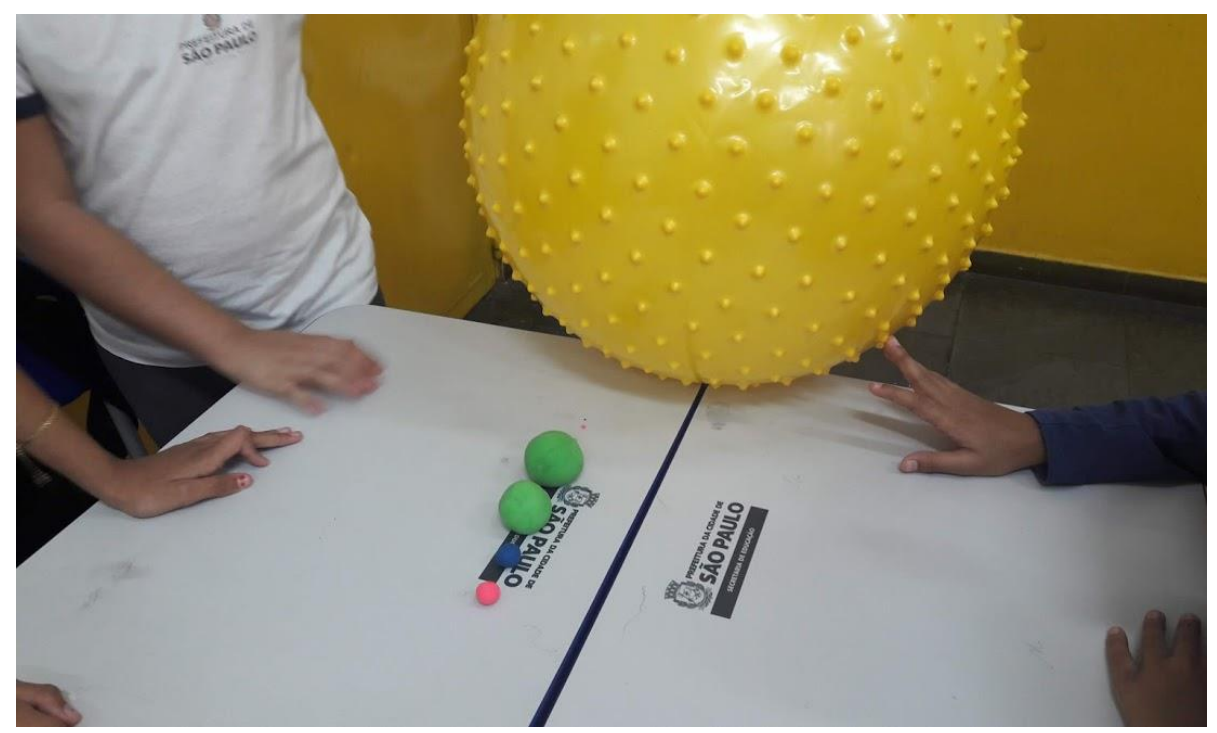

Lição de Casa: Desenhe o que você aprendeu nesta aula. 


\section{Aula 14 - Qual é a distância dos planetas?}

Objetivos específicos: Simular as distâncias dos planetas a partir do Sol.

Disciplinas envolvidas: Matemática, Geografia, Ciências.

Duração: 2 aulas

Material didático: Fitas de cetim já cortadas na medida correta para representar as "distâncias".

\section{Referência consultada:}

Atividade adaptada de: http://planetario.ufsc.br/o-sistema-solar/

\section{Descrição da atividade:}

Adaptamos a atividade http://planetario.ufsc.br/o-sistema-solar/ representando as distâncias com fitas de cetim.

O material ajudou os estudantes visualizarem as distâncias proporcionais. A seguir mostramos a tabela das medidas que utilizamos.

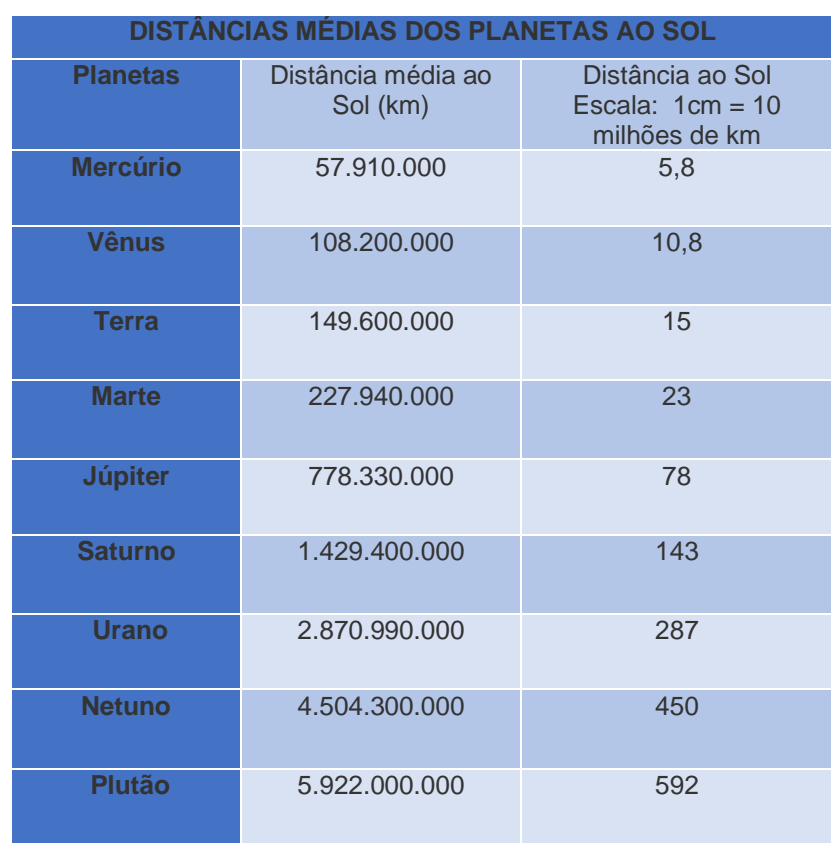

Fonte: http://planetario.ufsc.br/o-sistema-solar/ 


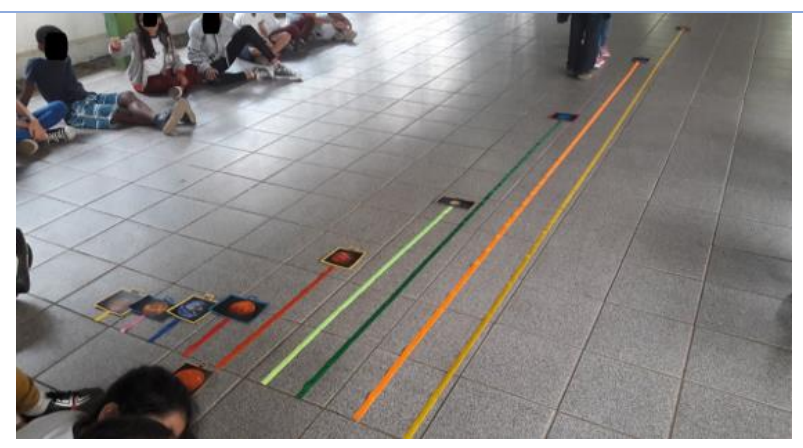

Lição de casa: De acordo com o que você aprendeu hoje, como você explicaria para uma criança as distâncias dos planetas?

\section{Aula 15 - Um jogo sobre o Sistema Solar}

Objetivos específicos: Complementar os estudos realizados, participando do jogo "Uma aventura pelo Sistema Solar"

Disciplinas envolvidas: Todas.

Duração: 2 aulas

Material didático: Jogo “Uma aventura pelo Sistema Solar" (É necessário organizar a impressão do material previamente).

Descrição da atividade:

Agora que os alunos já exploraram bastante as informações dos planetas que compõe o Sistema Solar, amplie os conhecimentos adquiridos por eles com um jogo de tabuleiro.

Observe como será o desempenho da turma.

Lição de casa: O que eu aprendi com o Jogo "Aventura pelo Sistema Solar"? O que eu já sabia? 


\section{Aula 16 - Avaliação: O que eu aprendi?}

Objetivos específicos: Relembrar o que foi aprendido com a SD.

Disciplinas envolvidas: Ciências, Língua Portuguesa e Arte.

Duração: 2 aulas

Material didático: Questionário (Anexo 1), folhas de sulfite, materiais para colorir.

Descrição da atividade:

Nesta aula, estamos chegando ao fim da primeira etapa desta Sequência Didática.

\section{1ㅇ momento:}

Organize os alunos em roda, e entregue para cada um o desenho feito no início desta SD.

Peça que eles contem se mudariam algo no desenho ou se acrescentariam alguma informação.

\section{2o- momento:}

Sugira que os alunos façam um novo desenho completando o com informações que signifiquem tudo o que eles aprenderam com esta atividade.

3o momento:

Responder ao mesmo questionário da aula 1, para avaliar o progresso das aprendizagens. 


\section{ANEXOS}

Todo material desta Sequência Didática, além de outros materiais como apresentação de aulas, vídeos, jogos, entre outros estão disponíveis em: http://www.iag.usp.br/ eder/CarolinaSilveiraLeite 


\section{ANEXO 1}

\begin{tabular}{|l|l|}
\hline Aluno (a): & Desenhe o lugar onde estamos no planeta \\
\hline Desenhe a Terra, o Sol e a Lua & \\
\hline & \\
\hline
\end{tabular}




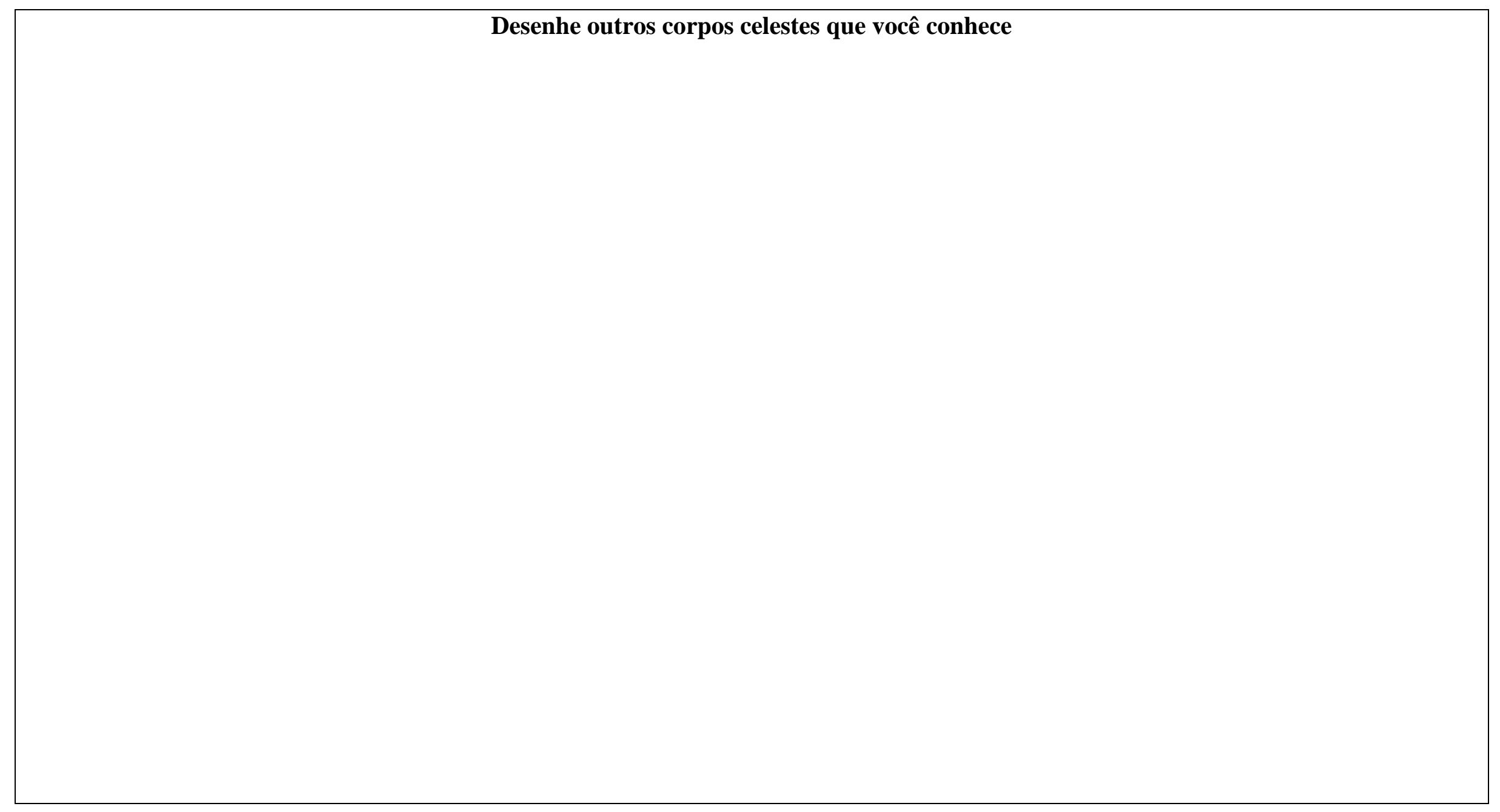


ANEXO 2

Aluno (a):

Data:

\section{Questionário diagnóstico:}

1) O que é o Universo? Como ele surgiu?

2) O que é o Sistema Solar? Como ele é formado?

3) Quais planetas você conhece?

4) Quem é maior que a Terra?

( ) a Lua

( ) o Sol

( ) Marte

5) Quem é maior?

( ) o Sol ( ) a Lua

6) Quem é maior?

( ) a Terra

( ) o Sol

( ) a Lua

7) A Terra está mais próxima:

( ) do Sol ( ) da Lua

8) Como ocorrem os dias e as noites? 


\section{ANEXO 3 \\ A criação do mundo \\ Lenda do povo Araweté, habitante da região do riu Xingu}

Houve um tempo em que o mundo era sem morte e sem trabalho. Existiam na terra os índios e os Mais, uma tribo de imponentes homens-deuses. Não havia as roças e nem o fogo; todos colhiam o mel e as frutas. Não se conheciam a doenças; a velhice e a morte não existiam. A floresta era amiga e os animais, dóceis. Durante as noites, os índios e os Mais fumavam grandes charutos, cantavam e dançavam; não se tinha inventado a mentira e a maldade; todos eram amigos, casava-se entre si e viviam em harmonia.

O chefe Mai, Ananãmi, havia se casado com uma índia. Moravam felizes em uma aldeia ao lado de árvores cheias de frutos e cipós floridos.

Um dia, sem motivo nenhum, a mulher de Anañami discutiu com ele. Levantou a voz e, aos gritos, o insultou. O mundo todos parou surpreso. Aquilo jamais havia sido visto.

O grande chefe Mai percebeu então que o paraíso estava morto. Chamou seu sobrinho Hehede, pegou seu chocalho de pajé e começou a cantar e a fumar. Foram rodeados por toda a aldeia, que se espantou quando o solo de pedra, onde estavam os dois, começou a subir sem arar até desaparecer nas alturas. Foi assim que surgiu o céu.

Estava feita a confusão na terra.

Muitos Mais subiram com Anañami. O céu povoou-se de guerreiros divinos, que levaram o paraíso com eles. As melhores plantas, os melhores animais foram viver nas alturas. Alguns Mais subiram mais aluto, criando o céu vermelho que era o céu do céu.

Abandonada e perdendo o seu suporte de pedras, a terra começou a se dissolver em água; jacarés e piranhas esfomeados saíram dos rios e devoraram os índios. Uma tribo Mai, que tinha ficado para trás, afundou n'água e entrou terra adentro. Passou a viver em grandes ilhas nos rios subterrâneos.

Os índios foram desaparecendo um a um. Os que não foram devorados acabaram por afogar-se. Só três pessoas escaparam. Dois homens e uma mulher, mais rápidos que os demais, subiram em um pé de bacaba e de lá assistiram ao desastre. Viriam a ser, depois, os pais de todos os índios.

Quando as águas desceram, a terra estava diferente. Aos poucos, povoou-se de animais ferozes; as árvores já não ofereciam tantas frutas; os sobreviventes tiveram que passar a pescar, caçar e plantar para viver. Anañami teve pena deles e mandou um pássaro vermelho para lhes ensinar a fazer fogo, plantar os roçados, construir canoas e tratar a grande quantidade de doenças que surgiram e a enterrar os mortos.

A vida no céu era muito diferente da que se levava na terra. Lá as sementes brotavam sozinhas, as frutas e o mel estavam ao alcance da mão. Anañami levou o segredo da juventude e não havia nada a fazer além de cantar, dançar e beber cauim. Os deuses eram bonitos e altos, o corpo pintado com tinta de jenipapo de um negro brilhante, e usavam maravilhosos cocares de penas de araras. Tudo era feito de pedra que não estraga com o tempo. E, se o tempo não se fazia sentir ao passar, então a vida deles era sempre presente e não existia futuro.

$\mathrm{Na}$ terra existia o tempo, o envelhecer, o esperar o dia de amanhã. O futuro. Na terra existia a esperança. Isso foi um presente de Anañami aos homens.

VAL, Vera do. A criação do mundo: e outras lendas da Amazônia. ilustrações de Geraldo Valério. - São Paulo: WMF Martins Fontes, 2008. P. 13 a 15. 


\section{ANEXO 4}

Aluno (a): Data:

\section{Lição de Casa}

- Leia atentamente o texto abaixo para responder as questões a seguir:

\section{O mito de Andrômeda}

Conta a lenda, que após uma vitória brilhante, Perseu voltou ao Oriente, para desfrutar de um descanso merecido na Etiópia. O rei Cefeu e sua bela esposa Cassiopeia, tinham uma filha, Andrômeda, que era ainda mais bonita que a mãe. Ambas se gabavam de terem beleza superior à das Nereidas e até à da orgulhosa Hera. As filhas de Nereu e a rainha das deusas foram se queixar ao poderoso senhor dos Mares. Poseidon, indignado com a pretensão das duas princesas, cobriu com suas águas as planícies verdejantes da Etiópia, destruindo frutos e plantações. Os homens e animais passaram a ser devorados por um monstro marinho que volta e meia rondava as praias. Conforme o costume da época, Cefeu foi procurar o oráculo.

- O que devo fazer para acabar com toda essa devastação?

- Para conseguir o perdão dos deuses, acorrente sua filha Andrômeda num rochedo, e o monstro se encarregará de consumar o castigo.

O pai resolveu acatar as orientações do oráculo. No mesmo dia, Perseu viu Andrômeda acorrentada num recife, e ao longe avistou o dorso imenso do monstro, que fazia as ondas se levantarem às alturas. O herói empunhou uma lança de aço, montou Pégaso e levantou voo sobre o mar. No momento em que o monstro abriu sua goela sanguinária, ele o atingiu com um golpe mortal.

Assim que se viu solta de suas correntes, Andrômeda

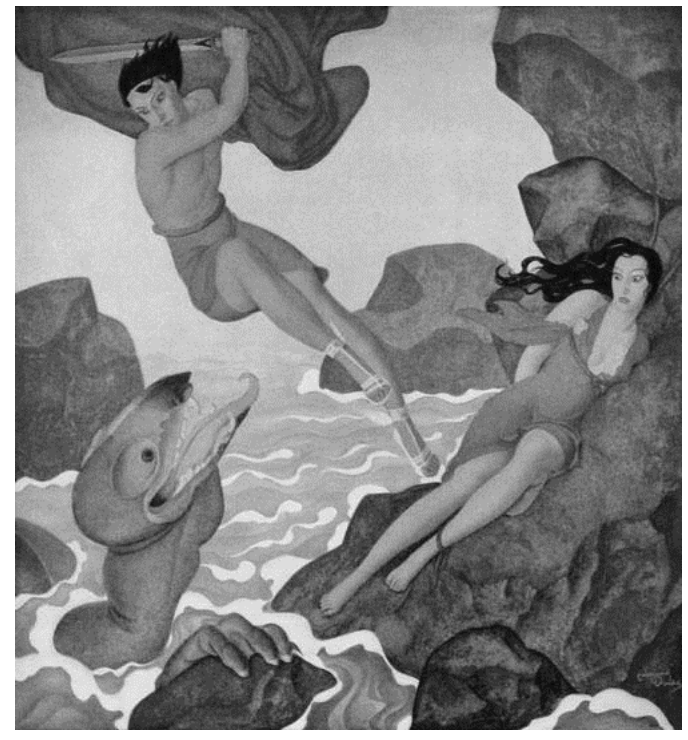
caiu nos braços de Perseu. Foi levada de volta aos pais e tornou-se esposa do herói.

1) O que significa a frase "o monstro se encarregará de consumar o castigo"?

2) Na sua opinião foi justo o castigo imposto a Andrômeda e sua família? Por quê? 
3) Você sabia que existe no céu uma constelação com o nome de Andrômeda? Trata-se de uma constelação criada pela cultura ocidental. Veja as estrelas abaixo (representadas por bolinhas) que formam essa constelação:

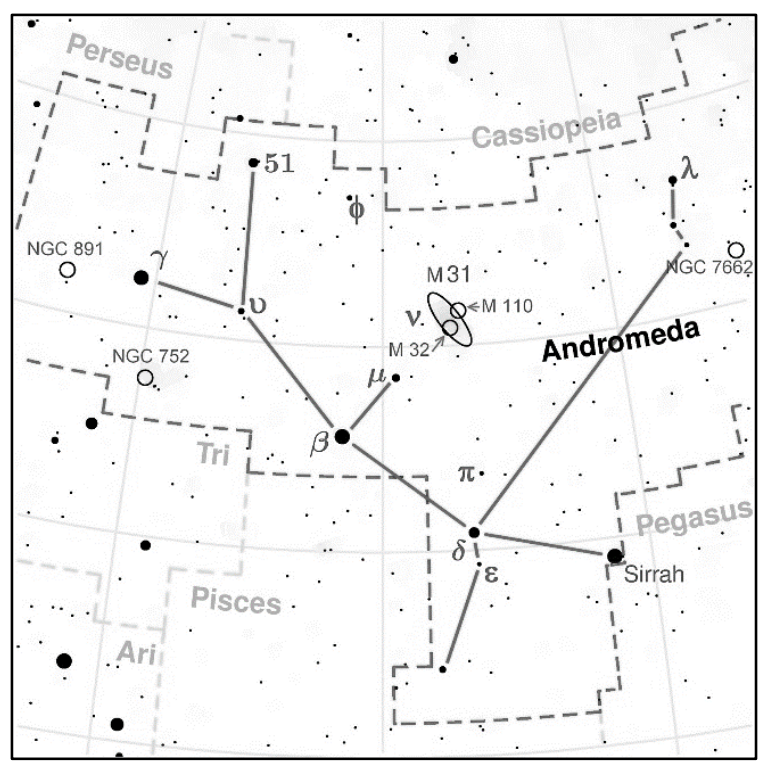

- Juntando estes pontos você consegue observar a imagem de uma princesa? Explique.

- Use a imaginação e crie a sua constelação com as estrelas da constelação de Andrômeda. Qual nome você daria a ela?

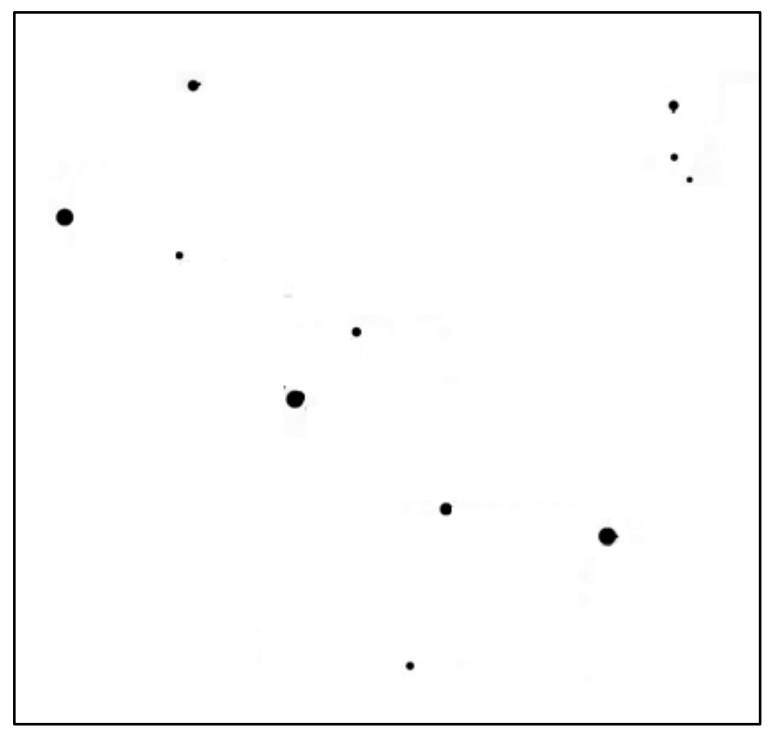


ANEXO 5

Aluno (a):

Data:

\section{Lição de Casa}

- Você deverá responder algumas perguntas. Para isso, pesquise informações sobre o Sol, e responda abaixo:

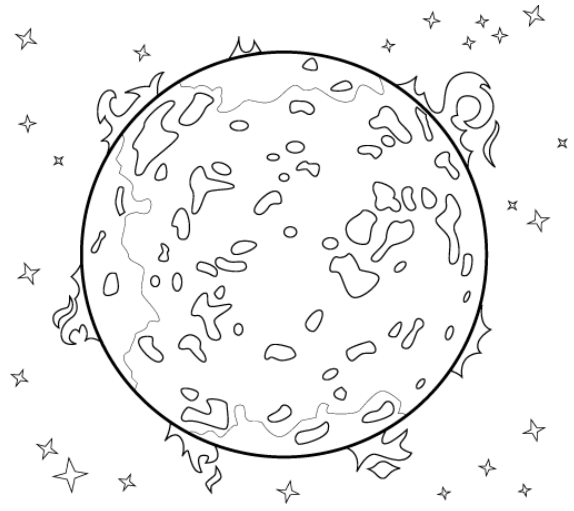

https://www.smartkids.com.br/colorir/desenho-sistema-solar-sol

Último acesso em 12/03/2018

1) Do que ele é formado?

2) Qual é a distância da Terra até o Sol?

3) Qual é seu o tamanho (em diâmetro)?

4) Quanto mede sua temperatura?

5) Curiosidades para compartilhar:

6) Fontes (Escreva onde você pesquisou, endereço na internet ou nome dos livros). 


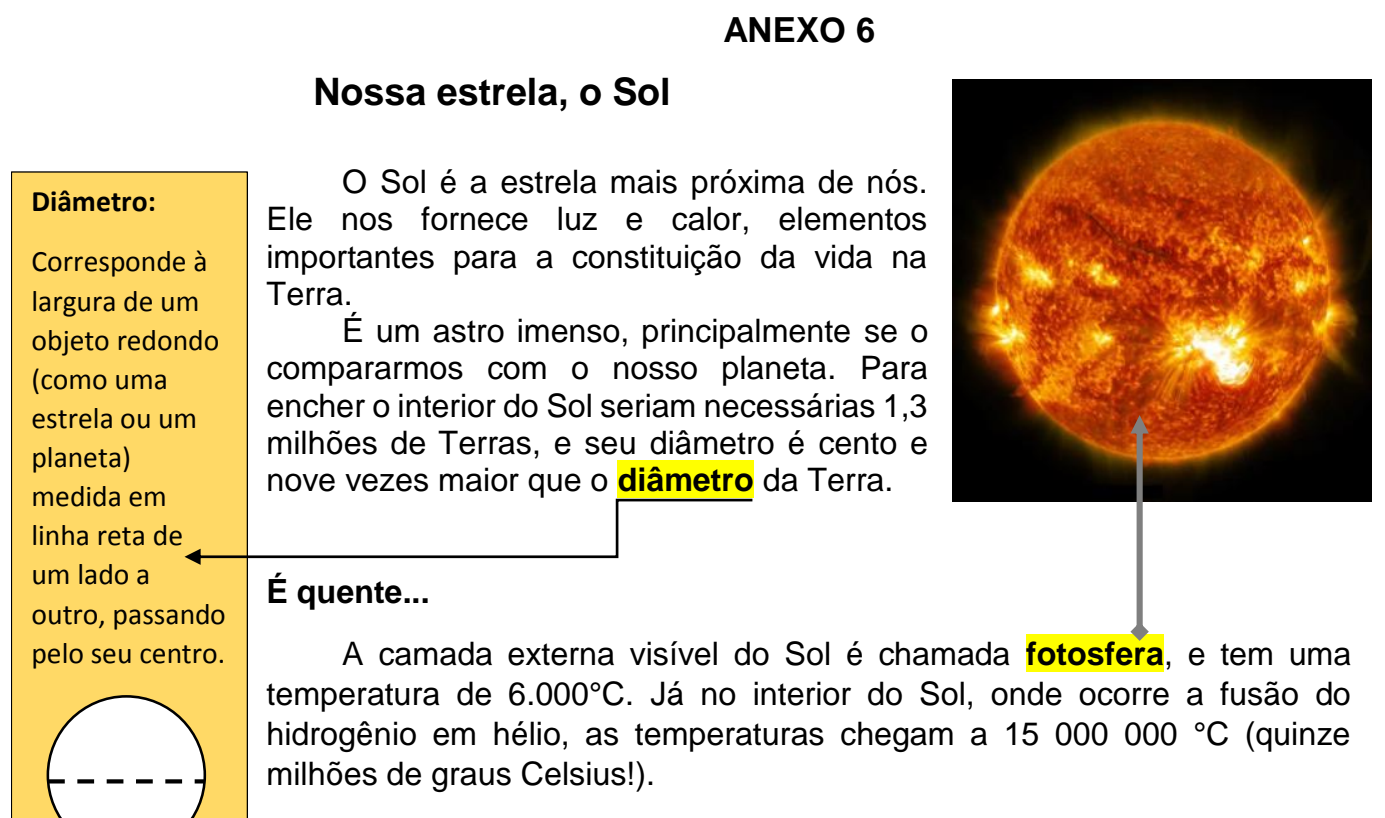

\begin{tabular}{|l|l|}
\hline Diâmetro & $1391980 \mathrm{~km}$ \\
\hline Distância média à Terra & $149597892 \mathrm{~km}$ \\
\hline Temperatura superficial & $5800 \mathrm{~K}$ \\
\hline
\end{tabular}

\section{Formação}

Acredita-se que o Sol se formou a partir de uma nuvem de gás e poeira gigante, conhecida como nebulosa solar. Essa nebulosa entrou em colapso por causa de sua gravidade, passando a girar muito rápido e se tornando achatada como um disco, a maior parte do material foi puxada em direção ao centro para formar o Sol.

Os astrônomos acreditam que o Sol brilha há 4,6 bilhões

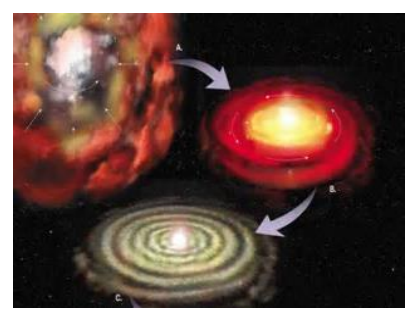
de anos e que tem combustível para queimar por mais outros 5 bilhões de anos. Depois disso, ele aumentará, transformando-se numa gigante vermelha, muito maior que seu tamanho atual, para depois se transformar numa anã branca.

\section{O Sol tem manchas e coroa?}

$\mathrm{Na}$ fotosfera solar observamos pequenas regiões escuras as quais chamamos de manchas solares. Elas são mais "frias", chegando a temperaturas $4.000^{\circ} \mathrm{C}$.

A coroa é a parte mais externa da atmosfera do Sol. É nesta região que as prominências aparecem. Prominências são imensas nuvens de gás aquecido e
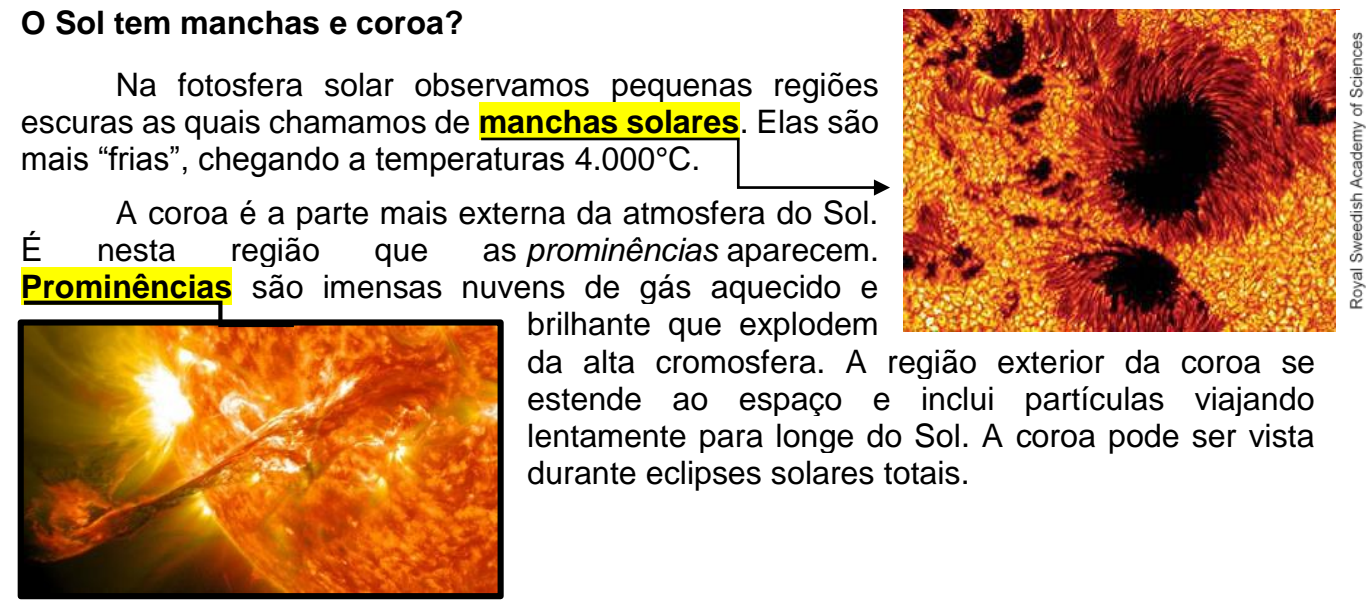
brilhante que explodem da alta cromosfera. A região exterior da coroa se estende ao espaço e inclui partículas viajando lentamente para longe do Sol. A coroa pode ser vista durante eclipses solares totais. 


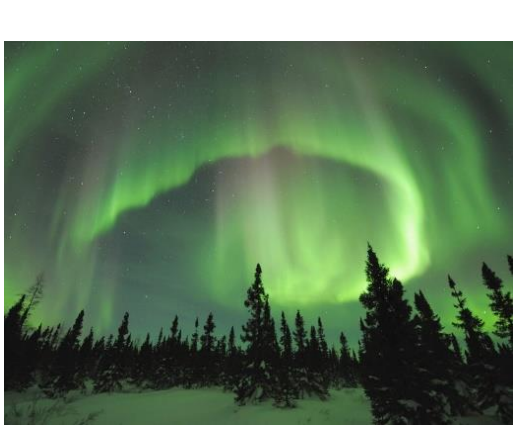

\section{ANEXO 6 \\ Auroras polares}

O vento solar são pequenas partículas que escapam do Sol. Um forte sopro pode perturbar o campo magnético da Terra e desencadear deslumbrantes shows de luzes no céu noturno. Este show de luzes são as auroras polares.

No Polo Norte, chama-se aurora boreal; no Sul, austral.

\section{O Sol e a mitologia}

O Sol está presente na mitologia de diversas civilizações. Para os gregos, o globo brilhante que surgia para trazer o dia, era o deus Hélios.

Para os egípcios, o deus do Sol, era chamado de $\overrightarrow{R a ́ . ~ E r a ~ a t r i b u i ́ d o ~}$ a ele a criação e a nomeação de tudo o que existe, de suas lágrimas surgiram os seres humanos que foram cuidados e providos para que nada Ihes faltasse. Ele era representado com cabeça de falcão sustentando uma serpente que contorna o disco solar.

Os Astecas também cultuavam o Sol, adorado pelo nome de Tonatiuh. Entretanto, a grande esfera brilhante que surgia no céu e com sua força trazia luz, calor e estimulava com seu ritmo a agricultura e a vida do povo, era personificada pelo deus Uitzilopochtli, o sol do meio-dia.

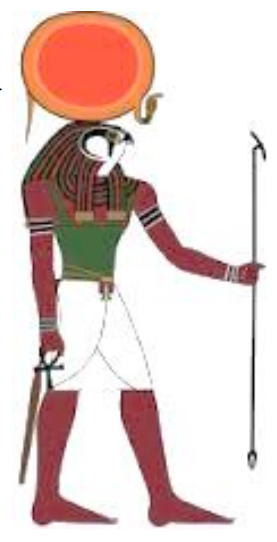

\section{VOCÊ SABIA?}

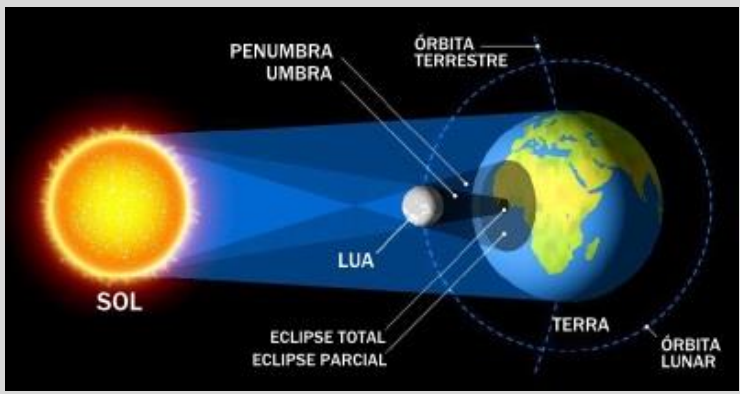

\section{ECLIPSES SOLARES}

Em algum momento de seu movimento em torno da Terra, a Lua entra em alinhamento, isto é, passa diretamente entre o Sol e a Terra. Ao passar em frente ao Sol, a Lua bloqueia os raios solares. Embora a Lua seja muito menor que o Sol, vista da Terra parece ser

mais ou menos do mesmo tamanho que ele, pelo fato de estar bem mais próxima do nosso planeta.

Em um eclipse total, a Lua bloqueia completamente a luz do Sol.

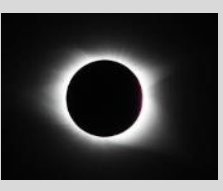
O céu fica escuro em pleno dia! Já em um eclipse parcial, apenas uma parte do Sol fica encoberto pela lua.

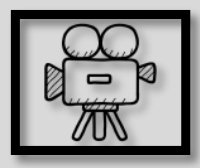

Assista ao vídeo para visualizar esse processo:

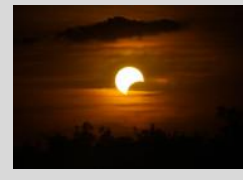
https://www.youtube.com/watch?v=fSR4r1HISJQ

Referências:

O Mais sensacional guia intergaláctico do espaço

Céu Noturno - Uma introdução para crianças

https://www.if.ufrgs.br/ast/solar/portug/sun.htm\#intro - Último acesso em: 19/03/2018

https://www.nasa.gov/content/goddard/sun-release-x3.1-class-solar-flare-on-oct-24-2014 - Último acesso em 15/03/2018

http://m.folha.uol.com.br/ciencia/2010/08/789930-manchas-solares-podem-mudar-duracao-dos-dias-terrestres.shtml?mobile

http://meioambiente.culturamix.com/natureza/origem-do-sistema-solar-nebulosas-de-kant-e-laplace

https://brasilescola.uol.com.br/geografia/eclipse-solar.htm 
ANEXO 7

Aluno (a):

Data:

\section{Lição de Casa}

Investigue:

1) O que é aurora boreal ou austral?

2) Como ocorre o fenômeno?

3) Em quais lugares podemos observar as auroras?

4) Cole uma imagem da aurora ou faça um desenho, observando uma fotografia.

5) Fonte (escreva os nomes de todos os sites ou livros que você pesquisou): 


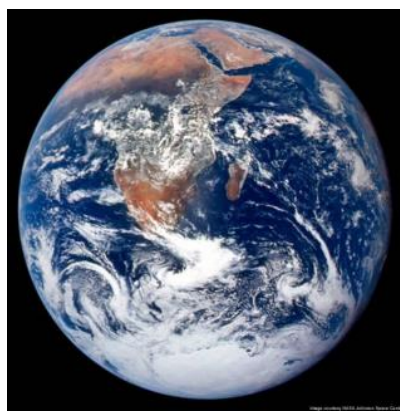

\section{Terra, nosso planeta}

A Terra é o nosso lar. É o quinto maior planeta do Sistema Solar e o terceiro em distância do Sol. Até o momento, é o único planeta que sabemos que abriga vida.

Acredita-se que a Terra se formou há 4,6 bilhões de anos, mais ou menos, no mesmo momento da formação do Sol e dos demais planetas, e desde então, ela vem passando por muitas transformações, até ser o que é hoje.

\section{A Terra em movimento}

Nosso planeta realiza o movimento de rotação e anslação, que são muito importantes. Entenda a seguir omo cada um funciona:

- Movimento de rotação: a Terra gira ao redor seu próprio eixo, ou seja, ao redor de si mesma.

\begin{tabular}{|l|l|}
\hline Distância até o Sol & $\mathbf{1 4 9} \mathbf{5 9 7} \mathbf{8 9 0} \mathbf{~ k m}$ \\
\hline Rotação & 23,9 horas \\
\hline Translação (ano) & 365 dias \\
\hline Diâmetro & $12735 \mathrm{~km}$ \\
\hline Satélites & Lua \\
\hline Temperatura máxima & $58^{\circ} \mathrm{C}$ \\
\hline Temperatura mínima & $-80{ }^{\circ} \mathrm{C}$ \\
\hline
\end{tabular}

Durante este movimento, o Sol vai iluminando progressivamente algumas regiões da Terra, enquanto outras vão deixando de ser iluminadas. Na região iluminada será dia, e na escura, será noite. Este movimento dura aproximadamente 24 horas.

- Movimento de translação: a Terra gira ao redor do Sol. Para completar esta volta, ela demora um ano. Este movimento dura cerca de 365 dias e 6 horas. A cada quatro anos, estas 6 horas formam mais um dia, que é acrescentado ao mês de fevereiro, compondo um ano com 366 dias. $\mathrm{O}$ chamamos de ano bissexto.

\section{Formação}

Nosso planeta é parecido com uma bola feita sobretudo de rocha e metal, dividida em camadas. pós a formação da Terra, o metal pesado afundou, formando o núcleo, e solidificou à medida que sfriava. Apresenta três camadas principais:

- Crosta terrestre: Camada superficial que circunda a Terra.

- Manto: É a camada que fica abaixo da crosta terrestre. Nela há vários tipos de rochas, que por estarem expostas a altas temperaturas, encontram-se num estado pastoso e recebem o nome de magma.

- Núcleo: É a parte central do planeta e acredita-se que seja formado por metais como ferro e níquel em altíssimas temperaturas.

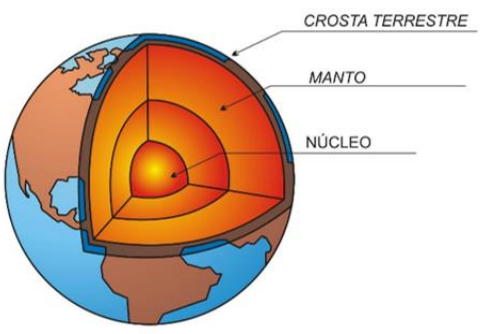

\section{Para saber mais:}

- De onde vem o dia e a noite? https://www.youtube.com/watch?v=Nux 3PVdo9U

- O movimento de translação. https://www.youtube.com/watch?v=DirknUkq FE

- Ano bissexto, ano da confusão. http://chc.cienciahoje.uol.com.br/ano-bissexto-ano-da-confusao/

Referências:

O Mais sensacional guia intergaláctico do espaço

Céu Noturno - Uma introdução para crianças

$O$ céu que nos envolve

O Planetário - Fernando Carraro

https://www.estudokids.com.br/camadas-da-terra/

http://www.cepa.if.usp.br/energia/energia1999/Grupo4B/Eneralte/Terra.htm 


\section{ANEXO 9}

Aluno(a):

Data:

\section{Lição de Casa}

1) Leia um trecho da música abaixo para responder as questões a seguir:

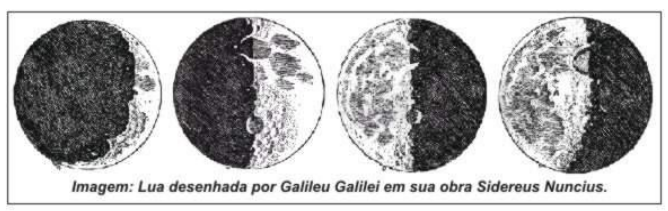

http://www.rea-brasil.org/lunar/topografia_lunar.htm

\section{A Lua}

A Lua

Quando ela roda

É Nova!

Crescente ou Meia

A Lua!

É Cheia!

E quando ela roda

Minguante e Meia

Depois é Lua novamente

Diiiizz!...

\section{MPB-4}

Quando ela roda

É Nova!

Crescente ou Meia

A Lua!

É Cheia!

E quando ela roda

Minguante e Meia

Depois é Lua-Nova...

Mente quem diz

Que a Lua é velha...

Mente quem diz!

https://www.letras.mus.br/mpb4/47527/ - Último acesso em 22/04/2018.

a) O que acontece com a Lua, nas diferentes situações, quando ela roda?

b) Você já reparou que a aparência da Lua muda de forma?

Desenhe abaixo a Lua em uma das formas que você já observou no céu. Você sabe como ela se chama nessa fase? Se sim, escreva como ela é popularmente chamada.

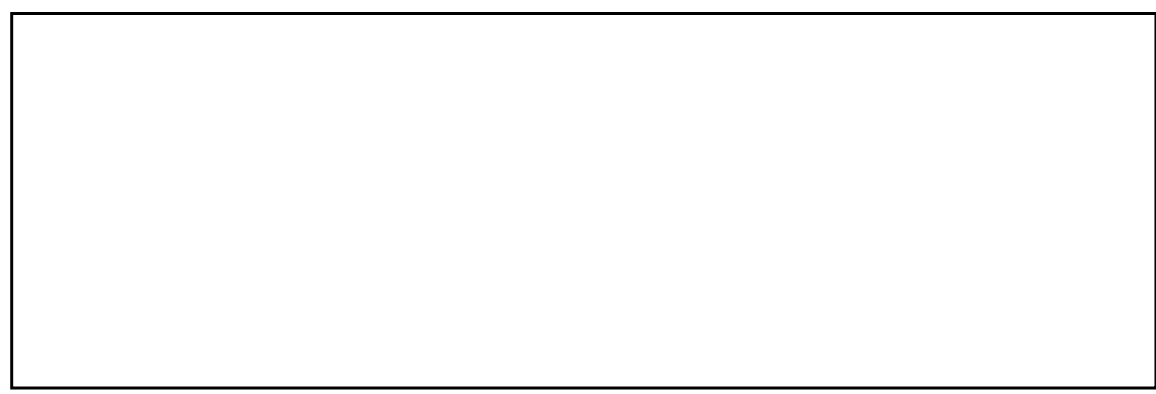

c) No trecho "Mente quem diz que a Lua é velha", você concorda com esta frase? Por quê? 


\section{ANEXO 10}

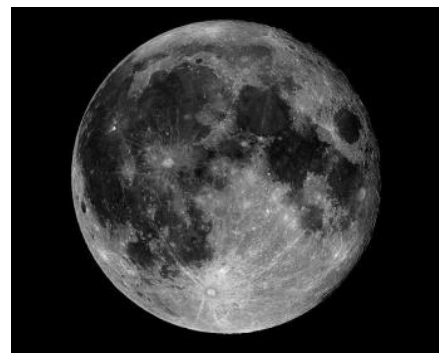

Nosso satélite, a Lua

A Lua é o único satélite natural da Terra. É um corpo rochoso, e assim como os planetas, não emite luz própria, apenas reflete a luz do Sol.

A distância da Terra até nosso satélite é de 384 mil quilômetros. Ela acompanha nossa jornada ao redor do Sol durante $\mathrm{o}$ ano, enquanto gira ao redor do nosso planeta. A Lua leva o mesmo tempo para girar ao redor da Terra e ao redor de si mesma. Este movimento dura 29 dias e meio. É por este motivo que sempre observamos aqui da Terra a mesma face da Lua.

Não há atmosfera e nem água em estado líquido em nosso satélite, o que impossibilita a existência de seres vivos.

\section{Origem e formação}

Acredita-se que há 4 bilhões de anos, um corpo do tamanho de Marte, denominado Thea, colidiu com a Terra ou passou muito de raspão por ela. Dessa colisão surgiu a Lua.

A Lua apresenta dois tipos de terreno:

- Mares: regiões baixas e escuras que se formaram por impactos violentos;

- Continentes: regiões altas, acidentadas, brilhantes e marcadas por crateras.

Toda a superfície lunar é coberta por uma poeira espessa, chamada de regolito, originada pelo impacto de rochas, conhecidos como meteoritos.

\section{Fases da Lua}

Você já reparou que a Lua muda continuamente de aparência ao longo das noites? Ao observar estes diferentes aspectos identificamos as fases da Lua. Ela possui quatro fases principais: Lua Nova, Quarto Crescente, Lua Cheia e Quarto Minguante. Isto ocorre porque a Lua reflete a luz do Sol, e por este motivo, ele vai iluminando sua superfície cada dia pouco a pouco, conforme a Lua e a Terra se movem ao redor do Sol. Esse processo dura aproximadamente 29 dia e meio. lado:

Observe o calendário ao

No dia 2, a Lua está na fase Quarto Crescente; ao passar alguns dias, no dia 10, ela estará na fase Lua Cheia. Em mais sete dias, teremos a fase Quarto Minguante. E no dia 24 chegamos a fase Lua Nova. Observe que a Lua Nova não é visível no céu noturno, pois a parte que o Sol está iluminando não é visível aqui da Terra, conforme vão passando os dias, o brilho vai crescendo progressivamente, e tudo recomeça.

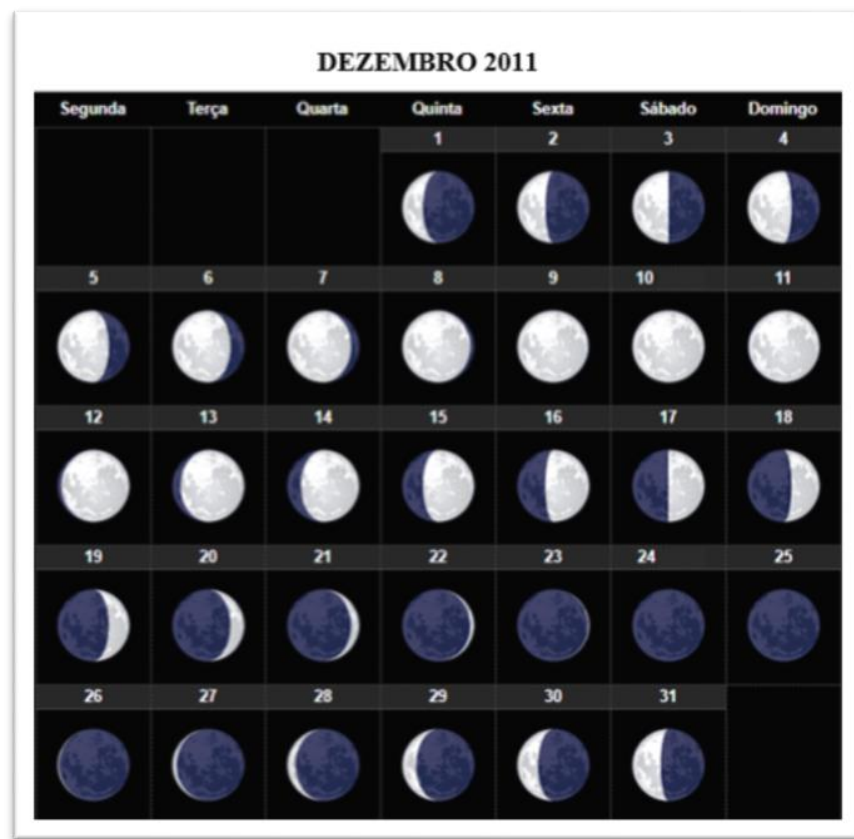




\section{Eclipse lunar}

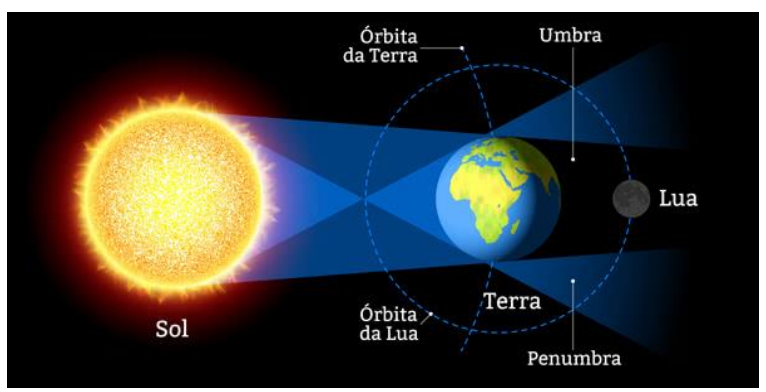

Quando ocorre um alinhamento especial entre - Sol, a Terra e a Lua, temos um eclipse lunar. Neste fenômeno a luz do Sol deixa de alcançar a Lua, que fica coberta pela sombra da Terra. É o eclipse! A Lua não desaparece no céu quando este fenômeno ocorre. Só desaparece se entrar uma nuvem no campo de visão do observador aqui do nosso planeta. Em um céu limpo, ela ficará avermelhada por causa dos raios solares

que atingem a atmosfera da Terra.

Outro detalhe importante de lembrar é que só há eclipse lunar quando a Lua está na fase Cheia, ou bem próxima desta fase. Mas não é em toda Lua Cheia que temos eclipse! Isto porque a Lua tem uma órbita que não fica alinhada todos os meses com a Terra e o Sol. Por isso, o eclipse é um fenômeno raro, e não ocorre todos os meses.

Veja mais em: https://www.youtube.com/watch?v=04shnr7xoQo

\section{Referências:}

http://www.iag.usp.br/astronomia/pergunta/1395576483

https://pt.tutiempo.net/lua/fases.htm (imagem calendário)

https://hypescience.com/10-fatos-incriveis-sobre-a-lua/ (Imagem Lua)

http://mundoeducacao.bol.uol.com.br/geografia/eclipse.htm (Imagem Eclipse)

http://astro.if.ufrgs.br/solar/moon.htm

O ABCD da Astronomia - J. E. Horvath.

Astronomia - Uma visão geral do Universo

$O$ céu que nos envolve. 


\section{ANEXO 11}

\section{Nosso Sistema Solar}

O Sistema Solar é formado pelo Sol, os planetas, satélites, planetas anões, asteroides, meteoroides, cometas e poeira zodiacal.

A nossa estrela, o Sol, é o maior astro desse sistema, e por isso fica no centro com os demais astros girando ao seu redor. fazem.

São oito os planetas do Sistema Solar, e eles não emitem luz própria, como as estrelas

Os planetas mais próximos do Sol são rochosos. São eles: Mercúrio, Vênus, Terra e Marte. Os planetas mais distantes do Sol são gasosos: Júpiter, Saturno, Urano e Netuno.

Os tamanhos dos planetas são muito diferentes entre si, e é muito difícil representá-los de forma correta. Na imagem abaixo, temos uma representação proporcional do tamanho deles.

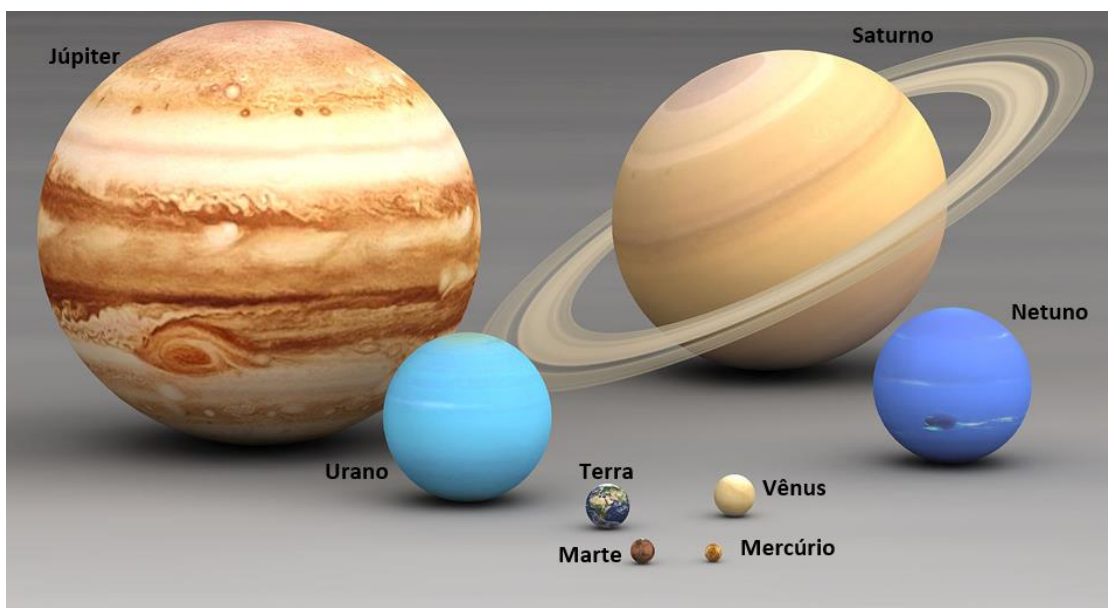

As distâncias entre os planetas são tão grandes que não é possível representá-las na distância correta em uma figura.

Veja na tabela as distâncias dos planetas até o Sol:

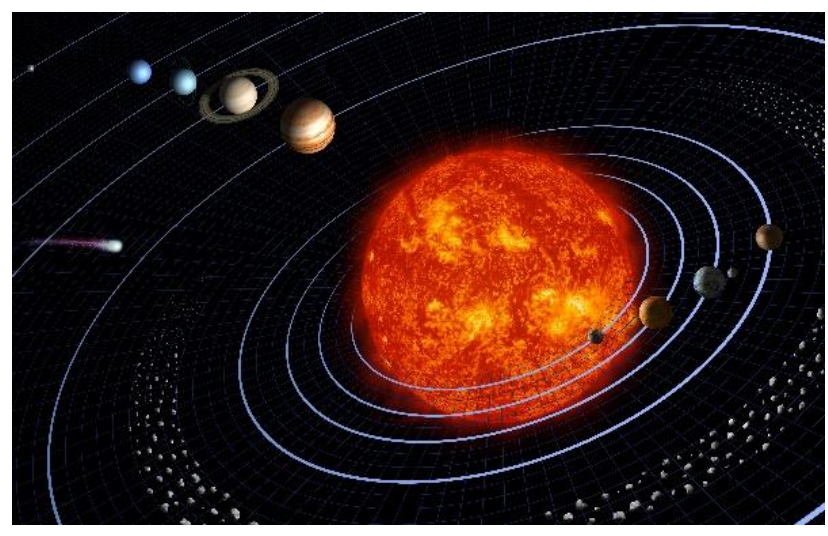

\begin{tabular}{|l|l|}
\hline Planetas & Distância em $(\mathrm{km})$ \\
\hline Mercúrio & 57910000 \\
\hline Vênus & 108200000 \\
\hline Terra & 149600000 \\
\hline Marte & 227940000 \\
\hline Júpiter & 778330000 \\
\hline Saturno & 1429400000 \\
\hline Urano & 2870990000 \\
\hline Netuno & 4504300000 \\
\hline
\end{tabular}

Os elementos mostrados na imagem e as distâncias entre eles não estão representados em proporção.

Referências:

OLIVEIRA, Kepler de; SARAIVA, Maria de Fátima. Astronomia \& Astrofísica. São Paulo: Editora Livraria da Física, 2013.

NOGUEIRA, S. CANALLE, J. B. G. Astronomia: ensino fundamental e médio. Brasília: MEC, SEB ; MCT ; AEB, 2009.- (Coleção Explorando o ensino ; v. 11) 


\section{Organizando sua pesquisa sobre planetas}

\section{- Etapa I:}

Reúna-se com seu grupo em sala de aula e combinem o item/tema que cada um pesquisará.

\section{Características:}

- Diâmetro:

- Distância do Sol:

- Duração do dia (rotação):

- Duração do ano (translação):

- Temperatura:

- Número de Satélites:

2. Curiosidades (Algo interessante para compartilhar):

3. Imagens (fotos e desenhos do astro pesquisado).

4. Perguntas feitas pelos colegas de turma:

1)

2)

3)

4)

5)

- Etapa II:

Combine com seus colegas de grupo o que cada um irá trazer para o cartaz, e a tarefa que cada um terá de realizar para confeccioná-lo. Observe ao lado um modelo de cartaz: trazer:

Quais materiais devo

( ) cartolina

( ) imagens

( ) régua, cola, compasso

( ) canetinha, lápis de cor

( ) outros materiais:

\section{- Etapa III:}

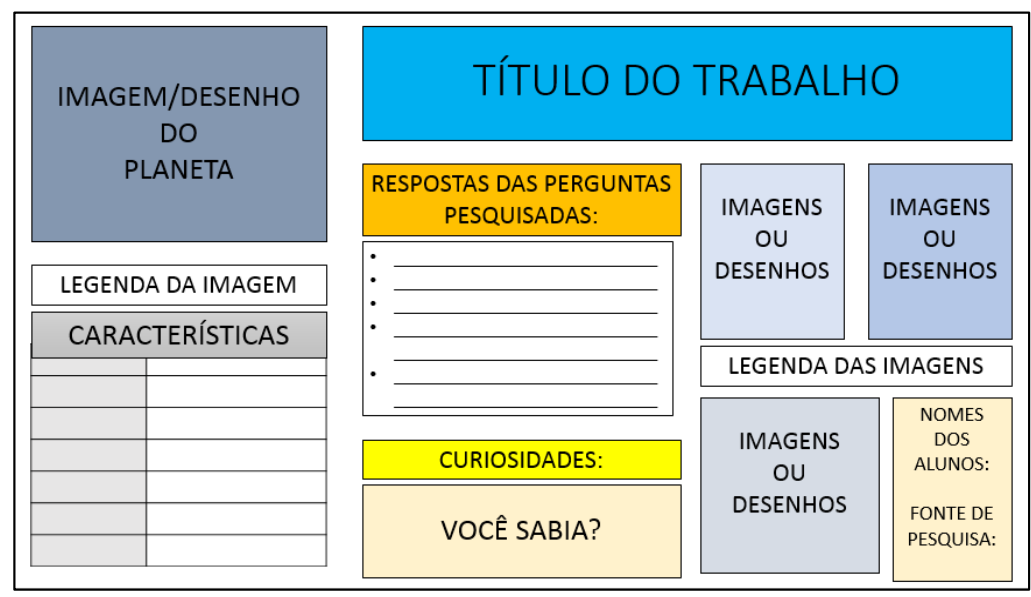

Estude a parte que você explicará na apresentação. O ideal é explicar com suas palavras o que compreendeu da pesquisa, portanto, não traga texto para ficar lendo. Estude e lembre-se que o cartaz poderá te ajudar também! No dia da apresentação seu grupo terá 10 minutos para explicar, por isso, combinem direitinho o que cada um falará. Ensaiem em casa com sua família (vai ser muito legal!) ou no recreio.

Ótimo trabalho! 
Aluno (a) :

\section{Autoavaliação sobre a pesquisa dos planetas}

Agora é o momento de você avaliar como foi sua participação no trabalho. Reflita e seja sincero em suas respostas. A cores pintadas não influenciarão em sua nota.

Leia cada item e:

* pinte de verde se você superou expectativas, fazendo além do que foi solicitado.

*pinte de amarelo se você atendeu os objetivos, realizando o que foi proposto.

*pinte de vermelho se você precisou de intervenções dos colegas e/ou professora.

\begin{tabular}{|c|l|l|}
\hline & \multicolumn{1}{|c|}{ CRITÉRIOS } & AVALIAÇÃO \\
\hline $\mathbf{1}$ & Consegui me concentrar e mantive o foco para realizar o trabalho. & \\
\hline $\mathbf{2}$ & Me organizei, respeitando as opiniões de todos e ouvindo sugestões. & \\
\hline $\mathbf{3}$ & Confeccionei o cartaz, realizando com capricho minha parte do trabalho. & \\
\hline $\mathbf{4}$ & Trouxe todos os materiais para a confecção do cartaz. & \\
\hline $\mathbf{5}$ & Realizei minha parte da pesquisa. & \\
\hline $\mathbf{6}$ & Mantive a sala de aula limpa e organizada; & \\
\hline $\mathbf{7}$ & Expliquei minha parte do trabalho. & \\
\hline
\end{tabular}

Agora, reflita e escreva:

- O que você aprendeu ao realizar esta atividade?

Considerações do professor: 
JOGO AULA 4

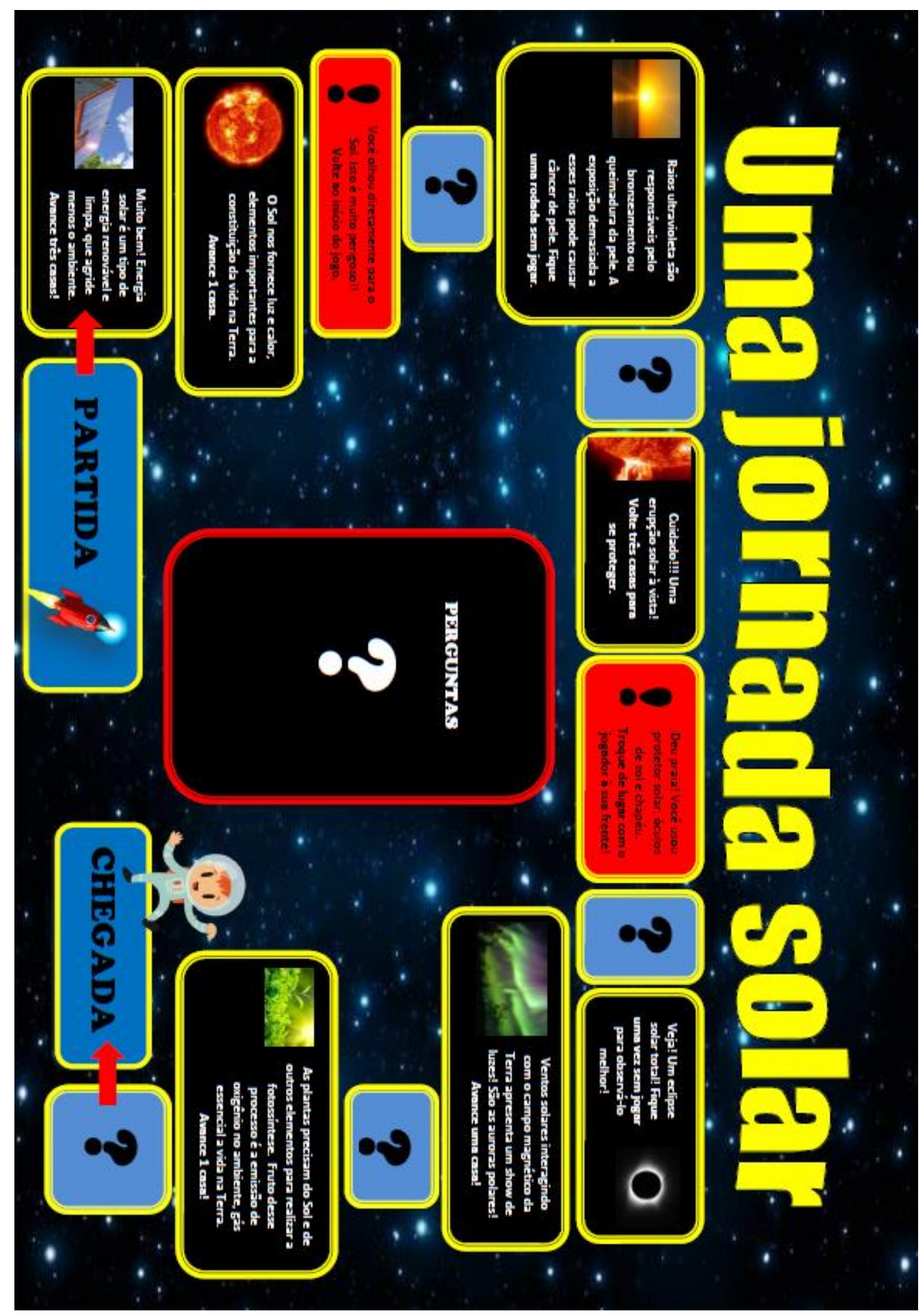


JOGO AULA 12

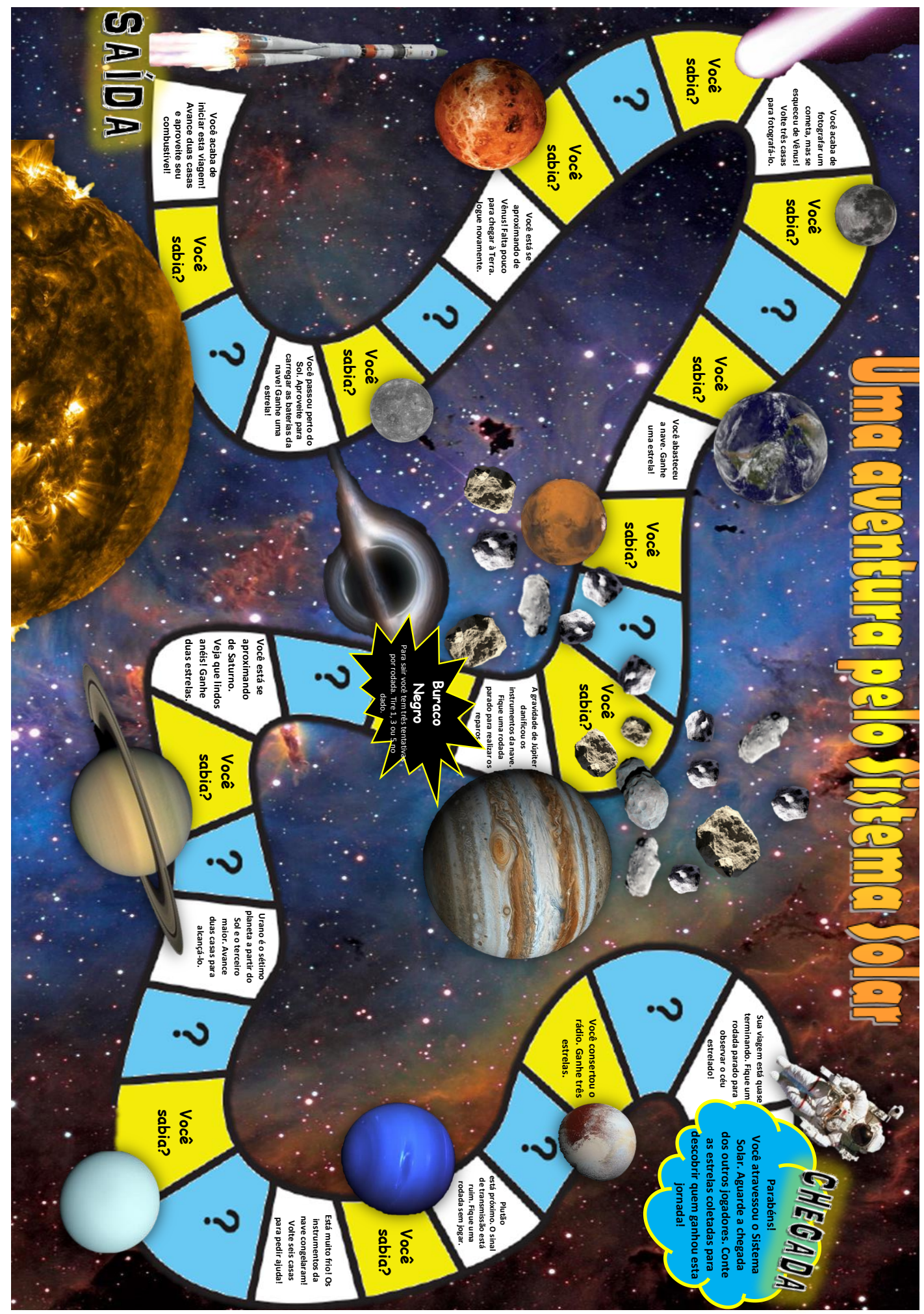

